\title{
Acerca de lo Narrado en la Performance:
}

Un estudio de la experiencia musical

del performer a través de la

analogía del Narrador

Matías Germán Tanco

Directora: Dra. Isabel Cecilia Martínez

Tesis Doctoral

La Plata, Septiembre de 2017 


\section{Agradecimientos}

Esta tesis ha sido posible gracias a la Universidad Nacional de La Plata y a su financiamiento económico a través de la Secretaría de Ciencia y Técnica, en el marco del sistema de Becas de Investigación y Desarrollo Científico, Tecnológico y Artístico. A través de sus diferentes etapas (Becas Tipo A y Tipo B), esta ayuda permitió el financiamiento exclusivo durante todo el desarrollo mi formación como investigador y la realización de la tesis.

A la Dra. Isabel Cecilia Martínez un profundo y especial agradecimiento por todos estos años de formación, trabajo y estudio; por haber fomentado en mí la vocación como docente e investigador, enfatizando una actitud responsable con respecto a las tareas académicas. En particular, por la dirección y acompañamiento constante durante la realización del estudio, y por la revisión de la escritura en la presente tesis, en el marco de las actividades de la beca universitaria. Por último, pero no menos importante, por su acompañamiento personal y emocional fundamentales para éste tipo de trabajo.

El desarrollo de la investigación que aquí se presenta hubiera sido imposible sin el apoyo y los aportes del grupo académico y colegas del Laboratorio para el Estudio de la Experiencia Musical (LEEM) de la Facultad de Bellas Artes, Universidad Nacional de La Plata y los equipos de investigación B298 La Corporeidad de la Mente Musical. Hacia una definición de su estatura en el estudio de la Ontogénesis, la Percepción y la Performance de la Música y PICT 2013-0368 Musicalidad Comunicativa en las Artes Temporales y la Infancia Temprana ambos dirigidos por la Dra. Isabel Cecilia Martínez.

A todos los profesores que dictaron los seminarios del Doctorado en Artes, por su conocimiento, colaboración y guía durante las cursadas, y por sus valiosos aportes en la corrección de los trabajos finales. En particular, a la Dra. Roxana Ynoub quien ayudó a darle un marco metodológico y enfoque a la tesis.

Agradezco especialmente a la Secretaria de Publicaciones y Posgrado, María Elena Larregle por su siempre amable y distinguida atención y rápida respuesta a todas las consultas y eventuales trámites administrativos que surgieron en las distintas instancias de la carrera.

Un gran reconocimiento a todos los docentes que me enseñaron desde los comienzos en mis estudios musicales a lo largo de los últimos 28 años, su dedicación y amor a la música, su paciencia y acompañamiento. 
A los músicos y amigos, con quienes compartimos proyectos musicales, ensayos, presentaciones en vivo, composiciones y grabaciones. Por el compañerismo, la complicidad, el juego, las charlas y reflexiones acerca de la música.

A mis compañeros de la cátedra Audioperceptiva 1 y 2, quienes comparten la tarea diaria y la reflexión acerca de la enseñanza musical. A los alumnos con quienes compartí todos estos años de actividad docente.

Agradezco también a todos mis compañeros, colegas y becarios del LEEM con quienes compartimos muchas horas de trabajo, discusiones, proyectos, congresos, cátedras, seminarios; quienes realizaron valiosos aportes para la investigación en música que intento desarrollar.

Un especial agradecimiento a los músicos que participaron en las entrevistas del presente estudio, por su predisposición, su confianza, su conocimiento y experiencia, fundamentales para la realización de ésta tesis.

A mi querida familia, por su amor y apoyo en todos los aspectos de mi vida, y en particular a mis padres quienes me acompañaron en todos estos años de estudio y dedicación a la música, la docencia y la investigación.

A todos ellos, ¡Gracias! 


\section{ÍNDICE}

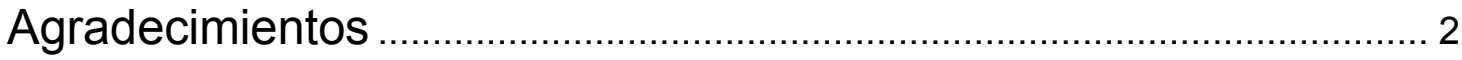

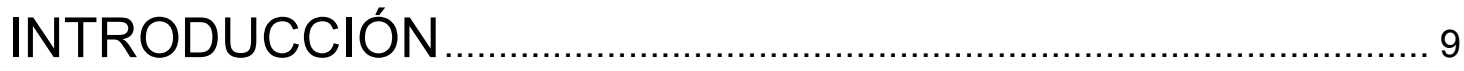

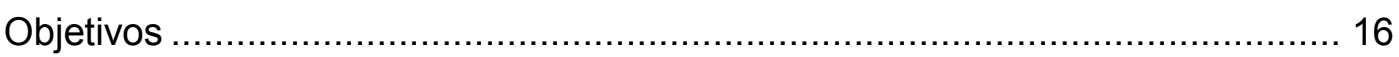

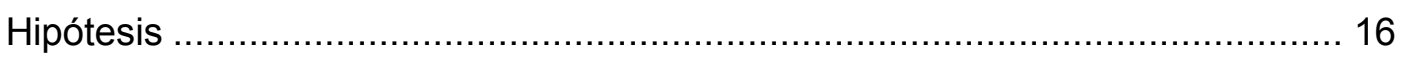

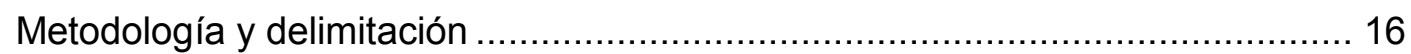

PARTE 1 - Marco Teórico …………………………………………........ 18

CAPÍTULO 1

Concepciones acerca de la música:

Obra, partitura, performance …………………………………..... 19

1.1 El concepto de obra musical ........................................................ 19

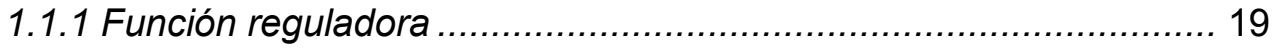

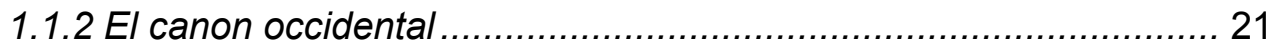

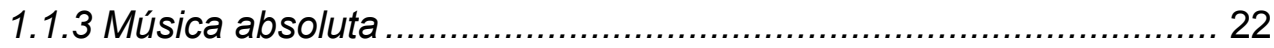

1.2 Perspectivas filosóficas ....................................................... 24

1.3 La obra musical como objeto intencional .......................................... 25

1.4 Los roles del compositor, el performer y el oyente .............................. 27

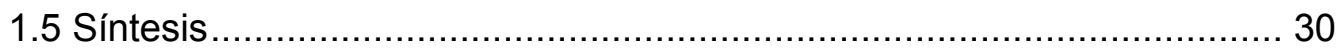

\section{CAPÍTULO 2}

Concepciones acerca de la performance:

Obra, texto, interpretación

2.1 La performance como disciplina musical........................................... 31

2.1.1 Concepciones acerca de la actividad del performer .................... 31

2.1.2 La investigación de la performance musical ................................. 33

2.1.3 La relación entre el compositor, la partitura, y el performer a lo largo de la historia ...................................... 34

2.2 La música como arte performático ................................................ 35

2.2.1 El paradigma clásico: tipo y caso .............................................. 36

2.2.2 Variedades de las teorías de tipo ........................................... 37

2.2.3 La performance como 'o inimitable' ........................................ 38 
2.3 La interpretación musical

2.3.1 La performance como reproducción, el performer como mediador 41

2.3.2 El texto musical. 43

2.3.3 La música como performance y las grabaciones 45

2.3.4 La performance más allá de la partitura 46

2.4 La performance musical, una vez más. 48

2.5 Síntesis. 49

\section{CAPÍTULO 3}

Narración y Música, Parte 1:

Analogías entre música y teoría literaria.

3.1 Narrativa y Música a finales del siglo XX 51

3.2 El abordaje de la música desde la teoría narrativa literaria ................... 53

3.2.1 Estructuras narrativas ........................................................ 54

3.2.2 La narrativización de la partitura ............................................ 55

3.2.3 Agencia.......................................................................... 56

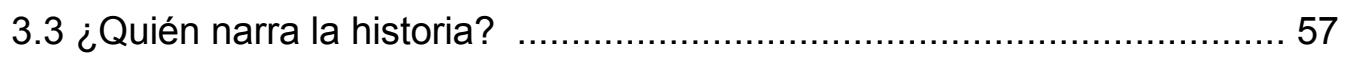

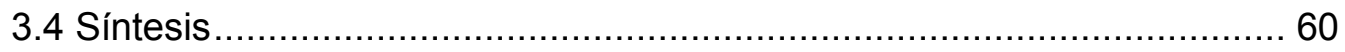

\section{CAPÍTULO 4}

Narración y Música, Parte 2:

Analogías entre interpretación musical y acto narrativo

4.1 El performer como narrador

4.2 La performance como focalización................................................. 62

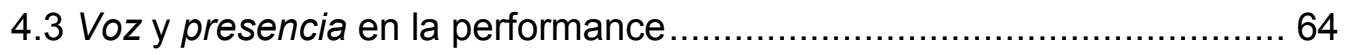

4.4 La performance como comunicación intersubjetiva.............................6 66

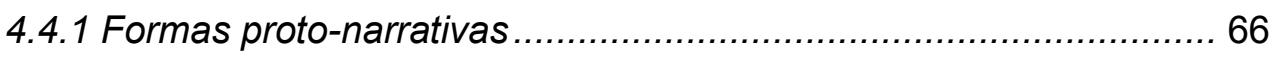

4.4.2 Musicalidad Comunicativa......................................................... 66

4.4.3 El performer como narrador y la comunicación

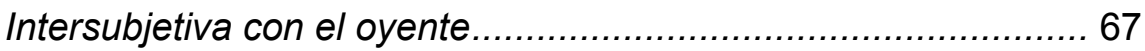

4.5 La narración en la psicología social: mundos posibles ..........................68 68

4.6 La narración en la cognición social: consciencia narrante...................... 71

4.7 Síntesis: acerca de lo narrado en la performance .............................. 72

4.7.1 Perspectivas sociales de la narración: la comunicación ................. 73

4.7.2 Mediación 1: el performer como lector ....................................... 74 
4.7.3 Mediación 2: narrador, voz narrativa y focalización ...................... 75

4.7.4 Mediación 3: narraciones posibles ........................................... 77

PARTE 2 - Estudios ....................................................................... 78

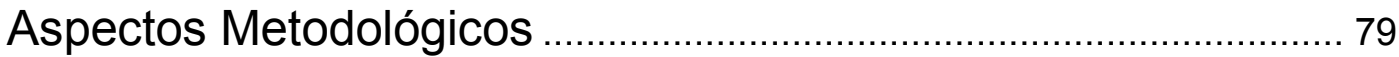

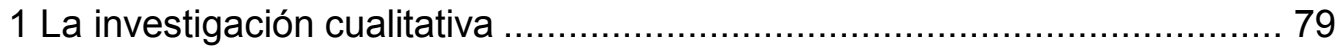

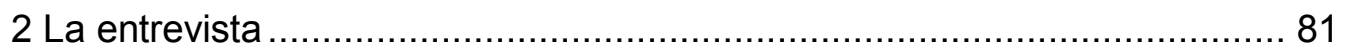

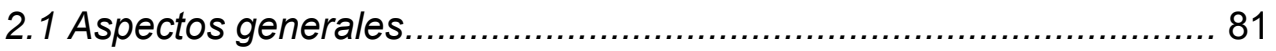

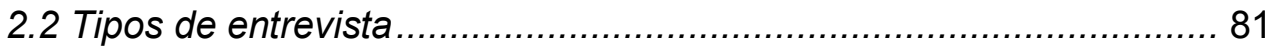

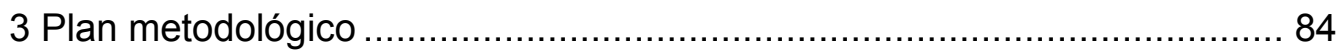

3.1 Organización del estudio.............................................................. 86

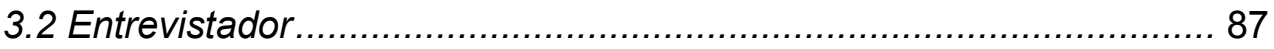

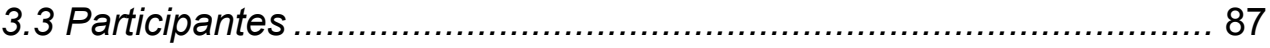

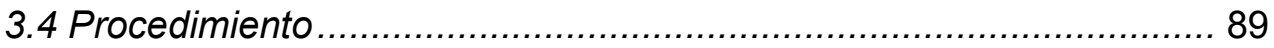

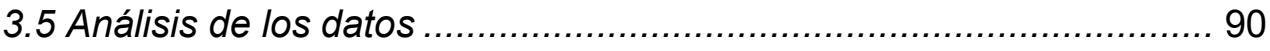

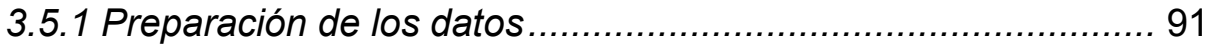

3.5.2 Reducción de los datos .................................................. 92

3.5.3 Preparación de la guía analítica ............................................. 93

3.5.4 Codificación de las entrevistas ........................................... 94

3.5.5 Presentación de la codificación ................................................ 95

3.5.6 Presentación e interpretación de los datos ............................ 96

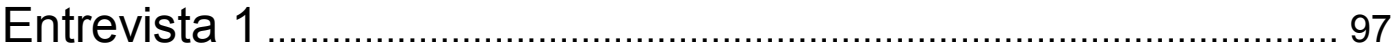

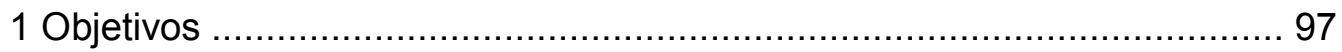

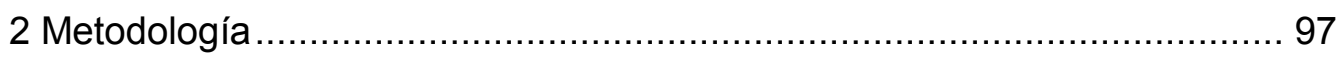

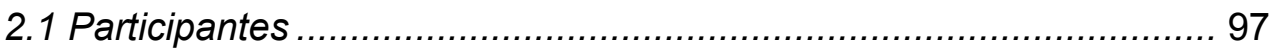

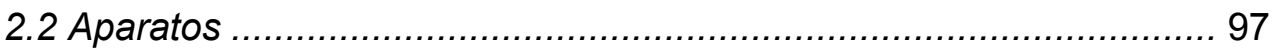

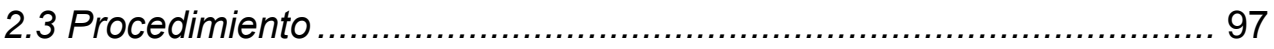

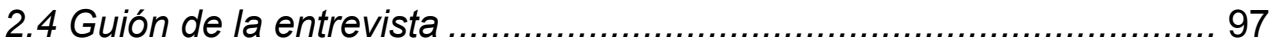

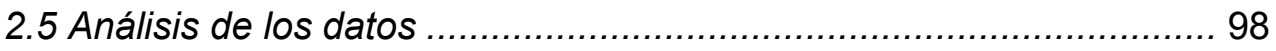

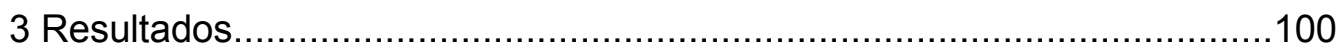

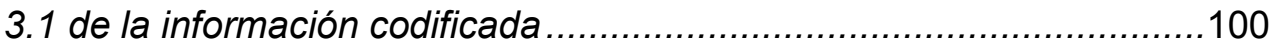

3.2 de la información no codificada ..................................................110

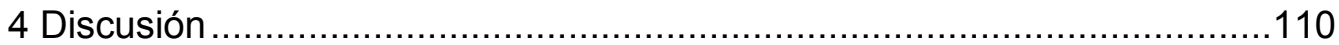




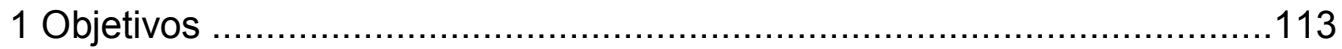

2 Metodología ................................................................................... 113

2.1 Guión de la entrevista ...............................................................113

2.2 Análisis de los datos ...................................................................113

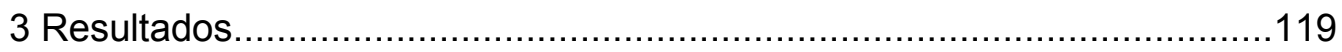

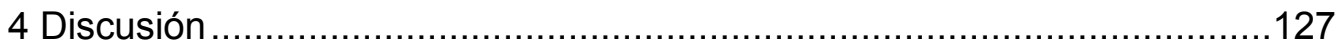

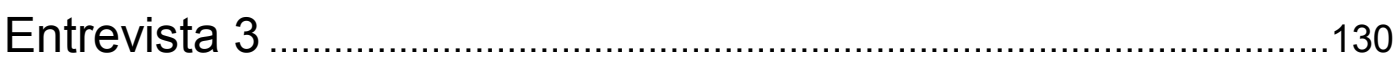

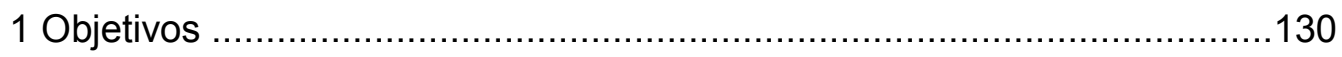

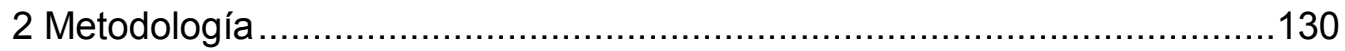

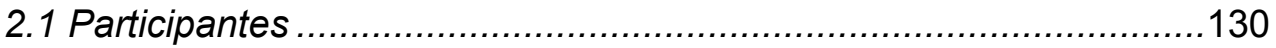

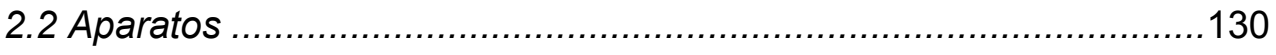

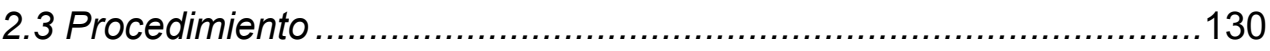

2.4 Guión de la entrevista ..............................................................131

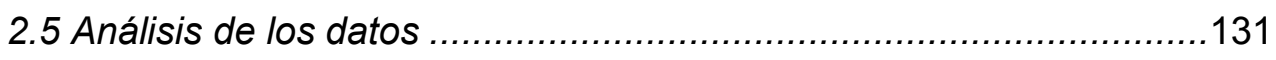

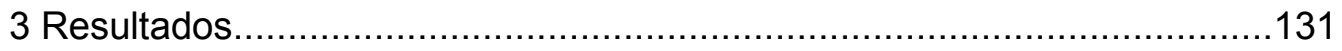

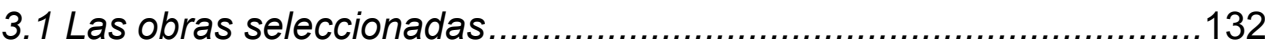

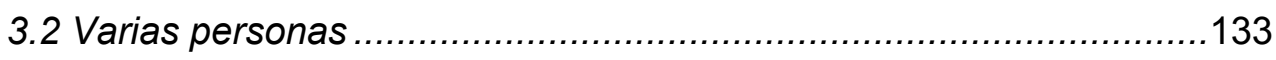

3.3 El vínculo entre el performer y la obra .......................................134

3.4 La preparación de la obra ............................................................135

3.5 Relaciones entre performances................................................135

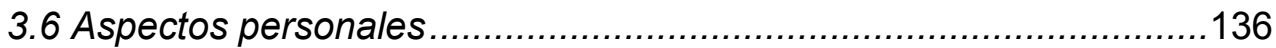

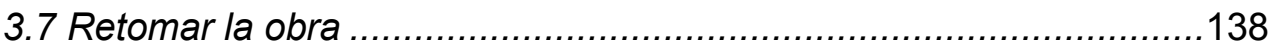

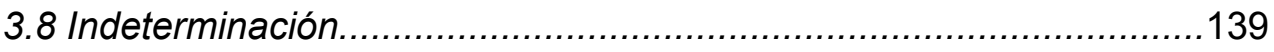

3.9 La relación dinámica con la obra...............................................140

3.10 El público ..................................................................... 141

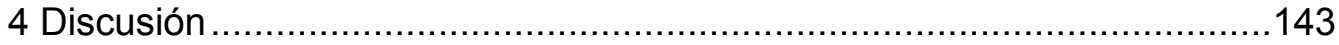

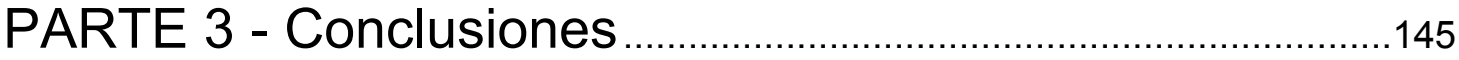

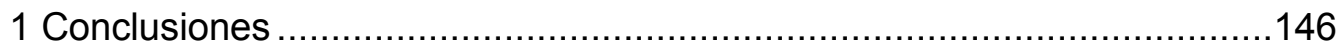

1 La interpretación de la partitura en un contexto de intencionalidades .......147

2 La comunicación en la performance ..................................................149

3 Acerca de la relación entre narrativa y música.......................................152

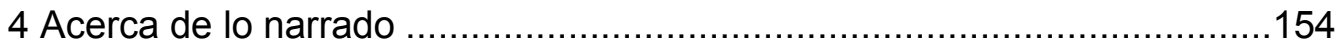


PARTE 4 - Apéndices 156

Apéndice 1 157

Apéndice 2 188

Apéndice 3 215

Referencias 241 


\section{INTRODUCCIÓN}

Esta tesis aborda uno de los aspectos que considero como el más fundamental de toda práctica musical: su relevancia social. El modo en que la música alcanza su mejor definición es en relación a los seres humanos, como una acción e intención humana. Pero también podría pensarse en el sentido inverso: el ser humano puede definirse en relación a la música. Entonces, a través de la música definimos lo que somos, quiénes somos, y también quiénes queremos ser, así como lo que hacemos y cuáles son las motivaciones que nos conducen a hacerlo.

La práctica musical es indagada aquí en su instancia de producción, enfocada en las personas que asumen el rol de preparar y presentar interpretaciones de obras musicales que ya han sido compuestas por otra persona (el compositor). Esta actividad, más allá de una habilidad o capacidad técnica, implica para el músico performer ${ }^{1}$ involucrarse personalmente en un tiempo particular de la experiencia, que es concebido en relación a la música o -más precisamente- a la obra y a la situación de presentarse ante los demás como músico intérprete.

El estudio que aquí introducimos se contextualiza en las prácticas actuales de la música académica, en particular de la música instrumental solista de los períodos Barroco, Clásico, Romántico y de Música Contemporánea, cuya presentación en público se realiza en salas de concierto (Small, 1998). Esta tradición musical continúa vigente en la actualidad en ámbitos públicos y privados de nuestro país. Por un lado, en el ámbito académico, las carreras de facultades y conservatorios abordan los repertorios anteriormente mencionados, incluyéndolos en sus programas de estudio. Por el otro, su permanencia es sustentada por políticas culturales: importantes teatros y salas de concierto, orquestas estables, orquestas-escuela, entre otras.

La performance musical que se realiza en público será uno de los temas principales de este estudio. El término performance puede referirse a una práctica artística que atraviesa disciplinas disímiles como la música, la danza y el teatro, las cuales comparten características temporales, corporales y presentacionales. En

\footnotetext{
${ }^{1}$ En esta tesis se utilizará el término performer para designar a la persona que toca y presenta la obra ante el público. En esta tesis el término performer será considerado también para ser aplicado en situaciones previas a la performance musical, como ocurre durante la lectura, interpretación y práctica de ensayo de una obra, aunque ésta no sea ejecutada ante el público. En resumen, el término designará al 'objeto' de estudio de la tesis, con un rol en la práctica para la producción musical que se diferencia del rol del compositor y del oyente/público. También podrá ser nombrado aquí como músico ejecutante, músico intérprete, o simplemente músico, o intérprete, sin modificar por esto su significado.
} 
música, es frecuentemente entendida como la producción de sonidos, gestos y movimientos que se realizan con la finalidad de dar sentido a la música.

En esta investigación definimos a la performance en relación a lo que ocurre en el evento en donde se realiza la presentación de la obra. Frecuentemente será llevada a cabo en un escenario (el marco de la escena), donde pueden haber luces más o menos enfocadas hacia el músico, quien realizará una ejecución en su instrumento musical mientras el público permanece sentado. La performance es un acto, no en el sentido de actuación, sino en el sentido de acción: se asiste a la presentación en vivo de una o más obras donde la atención se concentra sobre la ejecución del músico. ${ }^{2}$ Sin embargo, la performance que abordamos aquí va más allá de la reproducción de la música -frecuentemente entendida bajo el término de ejecución-; por el contrario, indagaremos en la actividad interpretativa de la música que un performer realiza en relación a un público, considerando a la performance como un fenómeno social particular con respecto al lugar y el tiempo en el que sucede.

En esta tesis indagamos la práctica musical desde la perspectiva del performer. Por lo tanto, problematizamos la concepción de la ejecución de una obra como su transmisión 'objetiva', así como cualquier otra concepción que intente invisibilizarlo en el involucramiento de una subjetividad o intersubjetividad en la elaboración de sentido. Intentaremos, en cambio, abordar aspectos de su actividad como una producción, que lo implican personalmente en la creación o re-creación de la obra musical -no necesariamente de la partitura o texto musical-, en el contexto de la performance: una actividad que se define a sí misma y que es determinada por aquello que ocurre en un tiempo y espacio específicos (y no como la simple reproducción de una obra ya creada en otro tiempo pasado).

Para el público, el performer está presente de alguna manera más allá de los sonidos que produce y de su imagen como entidad física percibida: el músico se involucra en una tarea de hacer sentido de la obra, un sentido personal y a la vez compartido con otros en el contexto de la performance. Debido a esto, nuestro estudio

\footnotetext{
${ }^{2}$ En esta tesis abordamos el modelo de performance del repertorio musical académico (Small, 1998). Desde aquel entonces hasta ahora, las prácticas musicales que se ocupan de la presentación de una obra o canción adquieren formas variadas y consolidadas en cada contexto particular. Por ejemplo, no todas las performances musicales involucran una producción sonora: pueden implicar la reproducción total o parcial de los sonidos en un playback, cuya implementación puede responder a diversos objetivos de la situación concreta. En tales casos se presenta una actuación que puede requerir de otro tipo de habilidades complejas como la sincronización, ya sea labial o de los movimientos y gestos que producen el sonido escuchado, o bien la presentación de dramatizaciones, o bailes coreografiados. Además, pueden incluir otro tipo de componentes visuales que incluyen la caracterización de los músicos, y adoptar formas de re-creación o imitación de sonido y apariencia de los artistas, como las que son realizadas por las bandas que realizan tributos (ver Frith, 1996).
} 
no se limita a indagar la performance in situ, sino que la performance es abordada desde el primer contacto que el performer tiene con la partitura, y su indagación llegará también a las instancias posteriores a su presentación en público.

Hace tiempo ya que las investigaciones en música cambiaron el objeto de estudio desde las partituras hacia las performances, lo que nos acercó a un conocimiento de la música como sonido. Sin embargo, las investigaciones siguen manteniendo una mirada externa a la práctica y, aunque estén informadas por los conocimientos y experiencia personal del investigador, muchas veces dejan a un lado la explicación personal del performer. Nosotros no buscaremos evidencia en las performances, ya sea en sus grabaciones o en el análisis de la señal sonora. Nos interesa, en cambio, conocer cómo es el pensamiento que conduce dichas acciones y cómo se manifiesta en las concepciones informadas por la práctica; esto es, en las palabras del músico que describe su experiencia.

Así como la obra es vista como un objeto inmanente ${ }^{3}$, las grabaciones de las interpretaciones de las obras musicales pueden llegar a constituirse también como performances inmanentes. Desde el desarrollo de la grabación, una misma performance puede ser reproducida y repetida en otro contexto espacio-temporal; de este modo adquiere un significado independiente al momento y a la situación en la que fue producida. Estas interpretaciones también alcanzan un estatus de modelo cuando son ponderadas por la crítica o la literatura musical. Nosotros entendemos que cada performance se vincula a un contexto de espacio y tiempo específicos, y que el paso del tiempo y el conocimiento personal producen cambios en nuestra mirada hacia la música. Debido a esto, lo que un músico realiza en una performance tiene valor en sí mismo en un contexto particular: hacia este objetivo es adonde van nuestras preguntas de estudio. La consideración de performances modélicas, ya sean ponderadas por un cánon establecido o avaladas por la autoridad de un performer, se aparta de los objetivos de la práctica interpretativa y performativa de la música, al considerarla como un objeto inmanente, posible de ser replicado. Dicho de manera directa, que una performance pueda llegar a ser considerada como representativa, o por encima de las demás no es algo de lo que trate esta tesis.

Esta investigación sí tiene que ver con el lugar del músico en su contexto social. Tratamos de entender qué implica pensar la música desde la actividad de la performance, desde el músico y el lugar en el que se posiciona. Existen concepciones que consideran que el rol del performer está devaluado, que lo que él debe llevar a cabo es la reproducción correcta -o lo más fielmente posible- de la partitura, como un mero intermediario: al centrarse en el análisis de la grabación de una performance, su

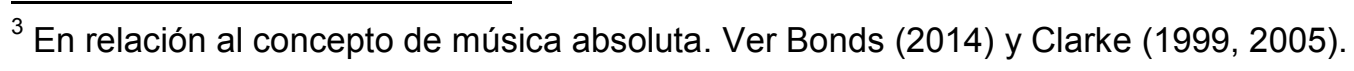


estudio se sustenta en la producción sonora en sí misma, en cierto modo separada del músico. Sin embargo nosotros entendemos que la performance implica una construcción interpretativa que excede el tiempo de la actuación, una habilidad técnica y un acto comunicativo que tiene una llegada al, y una recepción/devolución por parte del público. Entonces, en ésta tesis el rol del músico pasa a ser indagado como sujeto social en una serie de actividades reflexivas y prácticas que realiza con la obra desde el primer contacto con la partitura.

Los pensamientos y opiniones acerca de la práctica musical son fundamentales para el desarrollo de esta tesis. Una buena parte de la historia de la música y el pensamiento musical se ha ocupado de los compositores y su lugar de privilegio para el conocimiento, y poco lugar o nada han tenido los performers. Lo que a los compositores les preocupaba sobre la performance de sus obras eran las performances incorrectas, las malas interpretaciones. Muchas veces, la performance vista desde la composición se apoya en valoraciones hacia los performers como talentosos o mediocres. En nuestro caso, estudiar a los performers no nos ocupa en la consideración de las buenas y malas performances, por lo que no estableceremos las causas o las acciones que se desarrollan en vinculación a los aspectos técnicos instrumentales, ni tampoco vamos a registrar y medir las performances para compararlas con las partituras. Los músicos que participan de esta tesis son capaces de brindar una performance que no incumple con el 'deber hacia la obra', y el desempeño de cada uno en la tarea de la performance es capaz de validarlo.

El músico, en efecto, no escapa al deber de realizar una buena performance y esto tiene que ver con una buena parte de su trabajo. En este estudio, los músicos conocen, saben y padecen -como todos- este deber hacia la música, aunque nosotros preferimos no poner en primer plano estos aspectos por sobre los otros. Nos interesa, en cambio, que puedan dar cuenta de sus intenciones en la performance y conocer las concepciones que tienen acerca de las acciones que realizan: cómo conciben a la obra, de qué modo describen su relación con el compositor y el público, sus motivaciones para hacer música en el ámbito público y privado, así como también las motivaciones para volver a tocar una misma obra varias veces. En otras palabras, cómo se relacionan con la música desde su rol de performers en un contexto social actual.

Para nosotros, el músico -a diferencia de las obras inmanentes- está en constante movimiento y cambio, por lo que tampoco escapa a su contexto histórico y social. Su actividad tiene momentos personales de trabajo en solitario y momentos en los que trabaja con o para otros. Su pensamiento se vale, al menos, de estos dos tipos de instancias. La 'información' del estudio será entonces obtenida a través de las 
fuentes directas: músicos que trabajan con el conocimiento teórico y con el conocimiento práctico acerca de su performance. En cada caso, ellos cuentan con sus propias fuentes de consulta (escritas y orales) acerca de la performance y, fundamentalmente, con su recorrido y experiencia en la disciplina. Es decir que la información y la conceptualización disponibles llegan a nosotros a través de ellos, desde su mirada personal, objetiva y subjetiva del conocimiento musical. Una de las concepciones acerca de los performers es la que se construye sobre la idea de que realizan muchas horas de trabajo en solitario ${ }^{4}$, y que su tarea es el resultado de cierta introspección. Este es un imaginario que vamos a cuestionar, por lo que intentaremos demostrar que la tarea del performer es en sí misma concebida socialmente.

La metodología elegida plantea el abordaje cualitativo de la información a través de la realización de entrevistas. Los músicos que participan se involucran en una conversación con el investigador, en un ámbito que intenta ser abierto a los intereses de ambos. El análisis de la información considera que los entrevistados no tienen la mirada del investigador, y que los conceptos y concepciones que poseen pueden diferir de los marcos teóricos abordados en el marco de la investigación: es decir, no podemos considerar a todas sus palabras en el mismo sentido en el que las entendemos nosotros. Por lo tanto, la entrevista se propone la comprensión de la mirada del músico en una interacción de significados, que se realiza como una construcción intersubjetiva de la información entre el entrevistador y el entrevistado, en donde los términos de la información son evaluados y acordados por ambos.

La analogía de la narración en este caso nos permite desarrollar un pensamiento de tipo metafórico, más allá de la referencialidad o el sentido literal del lenguaje verbal. Se considera que esto permitirá entender aspectos de la experiencia del músico como performer, su relación con la práctica, su involucramiento con la música durante la performance, y la comunicación, en un contexto social, de intenciones e intencionalidades humanas. Más específicamente, se analizarán los datos relevados en función del performer entendido como un narrador, una analogía que lo pone en el centro de nuestro objeto de estudio: se espera obtener conclusiones acerca de su actividad desde una perspectiva personal y social. De esta manera, no serán los textos musicales (partituras) ni las performances analizadas las que sirvan para derivar las conclusiones o especulaciones acerca de sus intenciones performativas y/o narrativas, sino a través del modo en el que describen su campo de acción y pensamiento, bajo la consideración de un número de potenciales opciones que presenta la analogía del narrador. En este sentido, las hipótesis se presentan de un modo abierto para poder contener esas opciones.

\footnotetext{
4 "La naturaleza de la práctica o estudio -una actividad generalmente solitaria, totalmente opuesta a la interpretación como experiencia sumamente social." (Rink, 2002, p. xii)
} 
La música entendida en el marco de una narración nos permite abordarla desde su naturaleza temporal, que en el intérprete se lleva a cabo como una experiencia: entrando y saliendo desde el tiempo de la vida, del tiempo personal, al tiempo de la música, de la obra, y al tiempo compartido con los demás a través de la música. En este sentido, se contemplan las diferentes situaciones que forman parte de la vida del músico y su actividad: en dichas situaciones se producen las acciones realizadas, en sus contextos y encuentros con los demás, así como en la narración de su propia vida.

El estudio de la música a través de la analogía con la narrativa literaria ha sido abordado por muchos autores, desde diferentes enfoques. Se considera que no existe un acuerdo entre todos ellos, y que la temática se encuentra abierta a la producción de reflexiones, definiciones y nuevos aportes para desarrollarla. ${ }^{5}$ Una de las razones radica en que la analogía sólo permite comprender aspectos de la música en relación a la narración, pero en el intento de establecer una correspondencia estricta entre una y otra, ésta se debilita y es desacreditada. Sin embargo, establecer una analogía entre dos situaciones lleva implícita la imposibilidad de igualar a ambas; en cambio, es un recurso cognitivo del pensamiento para comprender a una en los términos de la otra, a través de las relaciones que puedan establecerse.

Por otro lado, la música encontró a lo largo de la historia nuevos modos de ser, de comunicar, de insertarse en la vida social; mientras algunos continúan en la discusión acerca de la narrativa musical abordando músicas del pasado como si estuvieran en el pasado, éstos nuevos modos desafían aquellas maneras de narrar: se trata, en definitiva, de las músicas y las narrativas posibles en los contextos actuales. ${ }^{6}$ Más específicamente, los teóricos e investigadores se basan en un conjunto de analogías posibles para la narrativa musical centrados en la obra como una entidad autónoma (la música): entre sus formas o esquemas y las estructuras o tramas de la literatura, o bien en el abordaje del análisis musical (descripciones narrativas de la música).

Al realizar una búsqueda en la literatura que aborda la relación entre narrativa y música, encontramos pocas referencias a la analogía del narrador. Esto puede deberse a dos motivos: (i) debido a la imposibilidad de la música para significar como lo hace el lenguaje, la figura del narrador en música es problemática de establecer y no suele ser abordada; (ii) el abordaje de la música se realiza a partir del análisis del texto.

\footnotetext{
5 Una revisión detallada acerca de la relación entre música y narrativa puede encontrarse en Almén (2008).

${ }^{6}$ Una mirada al respecto sobre música y narrativa puede encontrarse en Klein y Reyland (2013).
} 
La definición de narrador que nos interesa indagar aquí fue propuesta por Jerome Bruner (2002) cuando dijo, en relación a los cuentos, que:

...se precisa un narrador, un sujeto que cuenta y un objeto que es contado. (...) ...un cuento refleja de algún modo el punto de vista o la perspectiva o el conocimiento de mundo del narrador, es más, su 'veracidad' u 'objetividad', o inclusive su 'integridad', algo que debe ser difícil de descubrir." (p.34).

Unos pocos casos de investigadores que se interesan en una mirada de la música desde la performance proponen entender al performer como un narrador. ${ }^{7}$ Sin embargo, consideramos que estas propuestas surgen en la investigación a través de miradas del investigador que se analizan desde una posición externa al mundo del performer. Para abordar esta analogía como tema de estudio, nos hemos propuesto que esto surja de las mismas palabras de los músicos, sin embargo creemos que no podemos ir a preguntarles de un modo directo si se consideran narradores. Para esto, la interpretación de las palabras de los músicos debe poder ser realizada mediante el uso de las categorías descriptivas que surgen del análisis, y así poder aportar al desarrollo de la analogía performer-narrador niveles de descripción o, en caso contrario, poder descartarla.

La analogía entre narrativa y música será abordada aquí en función de poder pensar a la performance musical desde un punto de vista social y comunicativo; por lo tanto, no intentaremos igualarlas o establecer correspondencias definitivas. Aunque en su formulación teórica la analogía llegue a ser completa o consistente, no nos servirá a los objetivos de este estudio si no nos permite describir la experiencia del performer. Por otro lado, nos motiva el hecho de encontrar nuevas maneras de pensar y entender a la música desde un significado humano.

Las preguntas que nos interesan en esta investigación buscan adecuarse del modo más ecológico posible al contexto social, y se formulan de manera simple: ¿qué se está narrando?, ¿quién lo narra?, ¿cómo lo narra?, ¿en qué contexto se narra?, ¿a quién se lo está narrando? y ¿para qué se narra? o, si se prefiere, ¿para qué narrar? ${ }^{8}$

Las hipótesis de esta investigación son planteadas en relación a los abordajes anteriormente mencionados, nosotros partimos de allí para proponer hipótesis particulares que enfoquen el estudio de acuerdo a los intereses de esta tesis. Es por esto que en la investigación las hipótesis son consideradas con un cierto grado de apertura, de modo que nos permitan guiar el análisis de la información obtenida con el fin describir aspectos involucrados en la performance musical. Del mismo modo, las preguntas de las entrevistas se formulan como disparadores para la descripción de la

\footnotetext{
${ }^{7}$ Rink (1994, 1999) y Shifres (2007).

${ }^{8}$ En lugar de ¿es la música narrativa?, ¿cuál es la historia que narra la música?, ¿cómo se organiza la trama de esta obra?, ¿quién es el narrador en esta obra?, entre otras.
} 
experiencia de los músicos en la realización de su actividad y no indagan directamente las hipótesis propuestas. Como resultado, esperamos que las analogías posibles sean un medio para el conocimiento más que un fin en sí mismas.

\section{OBJETIVOS}

$\square$ Describir lo narrado en la performance musical entendiendo a ésta última como un acto intencional dentro de un contexto social del significación

$\square$ Establecer relaciones análogas entre narración y performance musical a partir de las concepciones que el performer tiene acerca de su actividad

$\square$ Conocer la experiencia del músico a lo largo del proceso de preparación y presentación de una obra musical ante el público

\section{HIPÓTESIS}

$\square$ La performance musical de una obra puede ser entendida de un modo análogo a la narración de una historia

$\square$ El performer realiza una performance musical de un modo análogo al rol de un narrador en un acto narrativo

- La preparación de la performance establece un vínculo entre el performer y la obra musical como un entramado enactivo de intenciones y significados sociales

\section{METODOLOGÍA Y DELIMITACIÓN}

Esta investigación se propone conocer aspectos de la performance musical en un contexto actual, a través de las personas que llevan a cabo dicha práctica. Esos aspectos buscan ser descriptos a través de relaciones análogas entre la performance musical y la narración como una actividad social. Por lo tanto, el estudio que esta tesis se propone es de naturaleza descriptiva. 
Para arribar a conclusiones acerca de esta actividad consideramos a la performance como una actividad intencional con fines comunicativos. Entendiendo que es el performer quien lleva a cabo la performance musical como una narración, su actividad performática será considerada de un modo análogo a la de un narrador en un acto narrativo con fines comunicativos.

Consideramos que una investigación que intente atribuir intencionalidades (sean musicales, creativas, performativas, interpretativas, comunicacionales, expresivas, personales o interpersonales) no debe ser indagada con una metodología cuantitativa o analítica que establezca consideraciones con respecto a los datos objetivos o a la experiencia personal del investigador. La investigación entonces debe ser abordada desde una perspectiva lo más cercana al músico, a partir de la implementación de una metodología que considere su perspectiva en la construcción de dichos actos significativos. Con tales fines, optamos por mantener un contacto directo y personal con los músicos a través de un intercambio con el investigador y la construcción intersubjetiva del significado de los datos (Høffding y Martiny, 2015).

La metodología a implementar en esta tesis será cualitativa: buscará describir en lugar de establecer causas, y lo hará adoptando la perspectiva del músico como persona, cómo se ven a sí mismos y a su mundo, a través de sus ideas, sentimientos y motivaciones internas (Taylor y Bogdan, 1984). Más específicamente, la información será obtenida a través de entrevistas semi-estructuradas que permitan a los músicos hablar libremente, con cierto control de los tiempos y las temáticas abordadas (LópezCano y San Cristóbal, 2014).

Las fuentes de información son músicos con 14 o más años de experiencia que dedican su actividad a la performance musical instrumental solista, que realizan o han realizado anteriormente performances en público. Todos ellos pertenecen al ámbito local comprendido por la provincia de Buenos Aires y alrededores. Además, cuentan con una formación académica en música, llevada a cabo en instituciones musicales (conservatorios y facultades) del ámbito local; la mayoría de ellos son además docentes de instrumento en las mismas instituciones. 
PARTE 1

Marco Teórico 


\section{CAPÍTULO 1}

Concepciones acerca de la música

Obra, partitura, performance

En este capítulo comenzamos a indagar en el conjunto de concepciones en donde se inserta la performance musical. Para esto, partimos del origen histórico del concepto de obra musical, que en la práctica de la tradición occidental europea se establece como el centro de referencia para el pensamiento acerca de la música. La discusión acerca del concepto de obra del canon universal es revisada en relación a las perspectivas de la obra como producto y como proceso. La música absoluta profundiza la idea de la obra autónoma y su organización auto-suficiente.

Luego, presentamos cuatro enfoques del pensamiento filosófico y estético de la música en relación a las obras musicales. A continuación, otra definición del concepto de obra musical se presenta como una alternativa para pensar la música, poniendo en relevancia la intencionalidad humana. Finalmente, la práctica musical es abordada a través de sus agentes sociales: compositor, performer y oyente. Este enfoque busca situar las problemáticas del modelo tradicional en la práctica y la acción que posibilitan el significado humano de la música.

\subsection{El concepto de obra musical}

\subsubsection{Función reguladora}

En el contexto de la tradición occidental centroeuropea el pensamiento de la música ha estado vinculado de una manera cercana al concepto de obra musical. El término define a "una única y objetivada expresión de un compositor, un artefacto público y permanentemente existente realizado de elementos musicales (típicamente notas, dinámicas, ritmos, armonías y timbres)" (Goehr, 1989, p. 55). La obra está fijada en la partitura a través de sus propiedades, siendo capaz de ser repetida en las performances, por lo que éstas últimas encuentran su definición en sentido inverso (hacia la obra): "las performances en sí mismas son eventos transitorios de sonido que tienen la intención de presentar una obra cumpliendo lo más cercanamente posible las especificaciones notacionales dadas" (p. 55). 
Según Goehr (1992), la emergencia de este concepto puede ser situada históricamente en la práctica musical clásica a fines del siglo XVIII, aunque esto no implica que anteriormente no puedan haber existido concepciones similares. El surgimiento es atribuído a la publicación de una prescripción escrita por E.T.A Hoffmann a principios del siglo XIX, la cual buscaba regular las actividades musicales (composición, performance, recepción, evaluación o análisis) en un contexto propio: de esta manera, las prácticas musicales ya no serían guiadas por consideraciones extramusicales (religiosas, sociales o científicas), sino por las obras mismas.

La investigación realizada por Goehr (1992) sitúa al concepto de obra en un contexto histórico y social, más específicamente en la regulación de la práctica en donde el músico finalmente era considerado como un trabajador. Según la autora, este abordaje histórico permite ver el surgimiento del concepto de obra musical y de sus concepciones derivadas para comprender que su permanencia hasta el dia de hoy es evidente en muchos ámbitos.

El escrito de Hoffmann produjo un cambio en la visión de la música en aquella época, lo que derivó en la organización de conceptos que ya estaban presentes en la práctica musical, pero que entonces comenzaron a definirse en función de y en relación a el concepto de obra como regulador central. Al mismo tiempo surgieron oposiciones conceptuales y nuevas formulaciones de viejas oposiciones (entre: la música compuesta y la música tocada; compositor y performer; música absoluta y música programática; composición y transcripción; y composición e improvisación). Goehr sostiene que el concepto de obra musical cumple una función regulativa de la práctica musical, y encuentra su mejor expresión en la noción de Werktrue, de Hoffmann, que significa "ser fiel a la obra" (Goehr, 1992, p. 1).

Este paradigma dominante en el pensamiento centroeuropeo desde 1800 hasta nuestros días fue definido por Goehr (1992) como 'el museo imaginario de las obras musicales', una institución que "considera sus actividades y metas como conceptualizaciones en términos de, y dirigidas hacia, la producción e interpretación de obras musicales" (p. 8). ${ }^{9}$ Como refuerzo de éste paradigma, en ese mismo período se escribieron bibliografías, biografías e historias de la música, todas centradas por primera vez en la idea de que los compositores estaban produciendo obras permanentes e independientemente únicas. Como ocurre con otros conceptos y concepciones de la música que pertenecen a este tipo de pensamiento o institución, el alcance del concepto se extendió de alguna manera hacia músicas de períodos anteriores y posteriores.

\footnotetext{
${ }^{9}$ La traducción es nuestra.
} 
El contexto histórico y social facilitó el surgimiento del concepto de obra y le permitió a la música en tanto actividad artística desarrollar su práctica en torno a los propios intereses de la disciplina, sin requerir de validaciones externas. Sumado a esto, influyeron también otros factores como la articulación de los conceptos de Bellas Artes con los de la autonomía de la obra de arte, la emancipación de la música (con respecto a la palabra), y otros más que serán abordados más adelante en relación al concepto de música absoluta.

La investigación de Goehr es ampliamente reconocida debido a su enfoque histórico y social, siendo aplicada en el estudio de los repertorios clásico y romántico de la práctica musical occidental. Sin embargo, también ha generado discusiones considerables entre aquellos investigadores de música antigua, debido a que sus objetos de estudio se veían disminuídos al quedar por fuera del concepto de obra musical.

\subsubsection{El canon occidental}

Según Butt, la tradición musicológica considera que en cualquier período determinado existen entidades fenomenológicas que pueden ser definidas como una "obra". Desde este punto de vista, las obras que adquieren una cierta autonomía son las que influyen en el desarrollo posterior del canon occidental y, por ende, pasan a formar parte de la tradición. Este punto de vista supone una distinción de grados de valor entre obras que se consideran más importantes y otras que no cumplen con éstos requisitos (Butt, 2015).

A partir del concepto de obra, entonces, se constituyó por primera vez en la historia de la práctica musical el canon universal, conformado por un cuerpo acumulativo de composiciones en expansión que incluye a lo que se considera como "lo mejor del pasado y del presente". Mientras que en el marco de este canon el lugar del compositor es central en relación a la composición de la obra, Talbot (2000) afirma que para la apreciación de la música clásica "seria" la identidad del compositor ha sido dispensada durante mucho tiempo. Los investigadores de música antigua han tenido que lidiar con el problema de las fuentes y copias manuscritas que en muchos casos han sido mal atribuídas a sus creadores, por lo que durante mucho tiempo las obras han tenido más protagonismo que sus compositores; sin embargo, en los dos últimos siglos la relación obra/compositor se ha revertido (Talbot, 2000).

Dado que el concepto de obra musical puede ser considerado para entender prácticas musicales en diferentes períodos de la historia (Goehr, 1992), se deben considerar al menos dos perspectivas en el pensamiento de la relación del compositor y su creación: como "producto" o como "proceso". 
Entender a la obra musical como un "producto" implica reconocer a una entidad estable definida por el compositor en su máximo detalle, según las posibilidades de la notación musical. Al cabo de un proceso sucesivo de estados (que pueden ocurrir en un período más extenso o más breve), el compositor finaliza la obra y establece el estado final en el texto, siendo este último el que representa sus últimas intenciones. $A$ partir de esta entidad que se reconoce como autónoma y estable, solamente el compositor tiene el derecho para revisar la obra y producir diferentes versiones de ésta. El concepto de obra musical visto de este modo es el producto del trabajo de un solo individuo, el genio creativo, y su estabilidad es autónoma e impermeable a las influencias externas. Por otro lado, entender a la obra como un "proceso" concibe a la creación como el resultado de una serie abierta de estados desde su comienzo hasta el presente, y hacia el futuro. Aquí el creador sigue siendo el agente iniciador (y el más importante), pero abierto a la participación de otros agentes que pueden contribuir al proceso a través de la creación de nuevos estados. Este punto de vista otorga un papel importante a los intérpretes bajo una concepción de la música como un arte escénico, entendiendo que tanto compositores como intérpretes son necesarios para la realización de una composición. Aquellos que ven a la obra como algo estable piensan que ésta puede ser representada por un solo texto, mientras que los que la ven como un producto tienden a ver al texto en relación a las performances (Broude, 2012).

El concepto de obra musical permitió a la música adquirir un estatus de obra de arte enfatizando sus aspectos estables y textuales, por encima de sus aspectos performáticos. En este sentido, la performance de la obra cumple una función de presentación siempre y cuando no altere el "producto". Desde ésta concepción, los aspectos creativos quedan reservados a una única persona que toma las decisiones hasta la finalización del texto musical. Esto supone que la obra está cerrada a la participación de otros agentes, y que la performance musical es una actividad necesaria únicamente para la presentación de la obra.

Considerar a la obra como producto o como proceso implica dos puntos de vista en relación a la obra: (i) en el primero, la música es determinada por una sóla persona (el compositor); (ii) en el segundo, la música está abierta a la participación de un número mayor de agentes, lo que implica la posibilidad de incluir un contexto de resignificación social para la obra.

\subsubsection{Música absoluta}

La música absoluta es un concepto vinculado a la música del siglo XIX. Comprende tanto a un paradigma como a las ideas básicas que guían la percepción y 
el pensamiento musical, implicando con esto qué es lo se entiende por música. Debido a estas características, Dahlhaus (1978) planteó que el concepto de la música absoluta puede ser considerado como un paradigma estético en sí mismo.

El uso más extendido de este concepto es el que alude a la "música sin texto", esto es, a la música instrumental "pura", sin referencias externas. Al separarse de lo demás, la música encuentra su identidad: su pureza es una verdad auto-evidente. Este nuevo concepto se alzó en contra de una idea que disminuía y situaba a la música instrumental por debajo de la música con palabras. La idea de música absoluta se separa de la idea de música con texto (poético), y de los programas o textos que la definen, surgiendo de allí la oposición entre lo musical y lo extra-musical.

El ser absoluto de la música implica una condición sin historia: como la de Dios (el absoluto de los absolutos). La condición de la música absoluta es la de haber estado allí siempre, eterna y absoluta. Para los Románticos, la música se equiparaba con el espíritu, algo demasiado etéreo (que no puede tener una historia) y trascendente que no compatibiliza con la idea de una contextualización (Chua, 1999). Su separación de la realidad histórica posiciona a la música en un "mundo aparte", reclamando la autonomía en función de su "pureza", amparándose así en una definición tautológica: la música es música. Según Clarke:

\footnotetext{
El término autonomía, que en un sentido literal significa auto-gobierno o autodeterminación, tal como se aplica a la música transmite la idea de un sistema que opera de acuerdo con principios internos auto-suficientes, una especie de formalismo idealizado y hermético. La palabra puede usarse tanto en relación a afirmaciones sobre piezas de música particulares como también como una descripción de una actitud de escucha que podría adoptarse en casi cualquier música. (Clarke, 2005, p. 128).
}

Este paradigma es frecuentemente asociado a la musicología debido al modo en el que ésta disciplina define el significado de la música y realiza los análisis de las obras a partir de los textos (partituras). Mientras que por un lado la música absoluta justifica un abordaje en sus propios términos, por el otro la obra musical adquiere un estatus "atemporal". Esto plantea los términos entre obra y práctica como una subordinación de la segunda hacia la primera: (i) la música que es reproducida difícilmente podrá alcanzar el estado de pureza, mientras que (ii) su recepción es definida como una contemplación de lo bello o la contemplación de un objeto completo en sí mismo; en palabras de Moritz, el objeto: "no se refiere a mí sino más bien yo me 
siento relacionado con él" (Moritz, en Dahlhaus, 1978, p. 8) ${ }^{10}$. Este modo en el que el sujeto se vincula con la música implica el apartarse de uno mismo, desde la existencia individual hacia el placer de una especie de existencia superior.

\subsection{Perspectivas filosóficas}

Desde entonces muchos filósofos han discutido la naturaleza de las obras musicales y las diversas implicancias de hablar sobre música en términos de obras. Goehr (1992), distingue cuatro enfoques básicos de acuerdo a lo que se especifica acerca de las obras musicales.

En el primer enfoque, el Platonista, las obras son universales -e incluso tipos naturales- constituidos por estructuras de sonidos que presentan cierto tipo de "inmaterialidad", ya que carecen de propiedades espacio-temporales; incluso se considera que existen eternamente -mucho antes de cualquier actividad compositiva- y que continuarán existiendo después que hayan sido olvidadas. Pueden considerarse dos sub-tipos de éste enfoque, según se conciba a la obra como un tipo independiente o bien en relaciones de dependencia con sus performances y partituras.

El segundo es el enfoque Aristotélico: considera que las obras son esencias de estructuras sonoras que son exhibidas en performances y partituras. A diferencia del enfoque Platonista, las obras son estructuras "esenciales" o patrones que pertenecen y son inherentes a otras cosas, en lugar de ser entidades distintas por derecho propio.

Un tercer modo de entender a las obras no les atribuye ninguna forma de existencia abstracta: las obras sólo existen de manera "concreta" en performances o partituras. El verticalismo entre la obra (abstracta) y sus performances (concretas) pasa a entonces a constituirse en una horizontalidad que existe entre las performances y sus copias escritas, entendiendo que mantienen relaciones apropiadas entre sí. Para Margolis (1974), una obra es una entidad cultural emergente, en un sentido que se materializa como objetos particulares dentro de un espacio cultural definido.

El cuarto es un enfoque Idealista, que identifica a las obras con ideas que son formadas en la mente de los compositores, y que una vez formadas encuentran una expresión objetivada a través de partituras o performances, lo que las vuelve accesibles al público.

Todos estos enfoques sintetizan la mayoría de las corrientes del pensamiento filosófico acerca de las obras musicales. La obra musical puede ser entendida desde

\footnotetext{
${ }^{10}$ La cita original corresponde a Karl Philipp Moritz. Schriften zur Astbetile und Poetik (Escritos de estética y poética). Ed. de I-lans-Joachim Schrimpf, Tubinga, 1962, p. 3.
} 
una concepción inmaterial, pasando por estructuras y entidades fijas, hasta su existencia concreta en las performances.

Nosotros entendemos que si bien es posible considerarla como una creación ideal, o una entidad inmaterial, los seres humanos también disfrutamos de la música y la hacemos parte de nuestra experiencia en el mundo. En un contexto cultural, la música puede ser vista como una creación humana además de ser resignificada por la misma cultura a través del tiempo. Esto requiere de un balance entre (i) sus aspectos ideales y objetivos, y (ii) el modo en que forma parte del mundo y nuestra experiencia en él:

Las piezas de música, ya sean recordadas, compuestas en la mente, anotadas o sonadas, son obviamente construcciones humanas de principio a fin, pero también adquieren un elemento de autonomía instantáneamente. No podemos predecir necesariamente cómo vamos a reaccionar o a concebirlas en algún momento en el futuro. Si de alguna manera somos cambiados a través de nuestro encuentro con la música, seguramente algo debe estar "allí" y no ser simplemente construido por nosotros de manera espontánea. Pero lo que sí nos muestra el argumento del constructivismo social es que lo que está "alli" no es una entidad estable que perdura independientemente de la energía que le demos. (Butt, 2015, p.5).

Avanzaremos entonces hacia concepciones de la obra y la práctica músical que nos permitan pensar en un sentido de significado e intencionalidad humana.

\subsection{La obra musical como objeto intencional}

Mientras que el concepto de obra musical del canon occidental se encuentra en la base del pensamiento musicológico acerca de la práctica de la música instrumental que indagamos en esta tesis, la concepción de la obra musical como objeto intencional cambiará el enfoque hacia un paradigma posible que nos permita entender a la práctica musical como actividad humana.

Esta idea planteada por Roman Ingarden se basa en Edmund Husserl y su desarrollo de la fenomenología. Husserl a su vez tomó estas ideas de Brentano, quien reformuló la idea de Aristóteles acerca de la intencionalidad y abordó la auto-evidencia de los estados mentales (Moran, 2000).

La obra musical es caracterizada por Ingarden (1986) como un objeto intencional: es aquel que depende de su existencia en las mentes conscientes y en los objetos reales, de los que puede abstraerse o inferirse su presencia. Los objetos reales comprenden tanto a los mentales como a los materiales mientras que, por el 
contrario, los objetos ideales son abstractos debido a que se encuentran fuera del espacio y el tiempo (por ejemplo, los números, universales y similares).

Para Ingarden, las partituras y las performances son determinadas en sus cualidades, mientras que las obras musicales son indeterminadas al considerar que estas permiten muchas interpretaciones posibles, pero igualmente fieles. La obra, la notación y la performance pueden entenderse como trascendiendo su existencia atribuída: (i) la notación trasciende las marcas de la escritura en el papel con la cual se correlaciona; (ii) la performance a su vez trasciende el sonido que percibimos; y (iii) por último la obra trasciende estas trascendencias. Es por esto que la obra se considera más abstracta y doblemente alejada del mundo real (aunque no llega a ser tan abstracta como lo son los objetos ideales) (Ingarden, 1986).

Como objeto intencional, la obra depende de objetos reales a partir de los cuales pueda ser inferida (partituras y otras representaciones similares). La obra a su vez no puede considerarse como un objeto ideal ni como un objeto real. Debido a que la creación de la obra ocurre en un momento particular y existe la posibilidad de que sea destruída (esto sería posible al eliminar sus objetos reales de los que depende su inferencia y existencia), no podría considerarse como un objeto ideal; por otro lado, la obra tampoco es un objeto real porque no se presenta a la percepción de manera directa, ni tiene una ubicación espacial.

Los objetos reales, por su parte, sí se transmiten inmediatamente a la percepción, pero tampoco dependen de su existencia en las mentes conscientes: son autónomos, mientras que los objetos intencionales son heterónomos. Sin embargo, en contraste con los objetos ideales, los objetos reales existen concretamente en el espacio y el tiempo, y sí pueden crearse o destruirse.

Los objetos intencionales (las obras musicales, en oposición a las sucesiones de sonidos) dejarían de existir si los seres conscientes fueran eliminados del mundo, o si los objetos reales a través de los cuales se detecta su presencia fueran destruidos. Esto no intenta decir que los objetos intencionales son subjetivos (determinados por las creencias o los deseos de cualquier persona en particular), sino que sus propiedades están sujetas a verificación interpersonal.

El planteo de Ingarden (1986) concibe a la obra como algo creado en un momento determinado que luego pasa a ser abstracto: está más allá de la notación y la performance, aunque no llega a ser un objeto ideal. Sin embargo, como un objeto intencional, la obra se define en las intenciones de los seres conscientes: aquellos quienes reconocen la importancia de una partitura o de su performance a través de sus propiedades, y que, a su vez, éstas propiedades son sujetas a una verificación que se lleva a cabo de un modo interpersonal. 
Según Davies (1988), Ingarden intenta demostrar que las manifestaciones verdaderas de una obra musical no son verdaderas por los objetos ideales, y tampoco por los objetos reales en los que ésta podría concretarse. Debido a que en la "naturaleza" de la partitura existe un espacio para varias interpretaciones -muchas de ellas no previstas por el compositor- la obra finalmente existe heterónomamente a través de los actos intencionales de los performers y los oyentes (Davies, 1988).

De esta manera, podemos concebir a la obra musical tanto desde sus aspectos ideales como intencionales que le dan sentido en un contexto social. De todos modos, debemos profundizar en aspectos de la práctica que permitan entenderla como el resultado de una construcción de significación entre agentes sociales de la música, entendidos tradicionalmente como el compositor, el performer y el oyente.

\subsection{Los roles del compositor, el performer y el oyente}

Como hemos mencionado anteriormente, la regulación de la práctica musical estableció una serie de roles sociales o funciones que se entienden en relación al concepto de obra musical. En nuestro caso, y en vistas a contextualizar el marco teórico en el paradigma centroeuropeo de la música en torno a la obra musical, presentaremos algunas ideas de Roger Sessions (1950), quien abordó la separación de los roles sociales de la práctica musical entre el compositor, el performer y el oyente. Sin embargo, existen también otros abordajes en investigaciones que estudian el origen y la función social de la música en contextos no occidentales, donde los roles no son definidos del mismo modo, abordando aspectos sociales e intencionales de la música (Cross, 2010) ${ }^{11}$ de un modo diferente al que lo haremos aquí, en el contexto de la práctica musical especializada de occidente.

Sessions (1950) brinda una hipótesis acerca de los tres roles arriba mencionados como grados sucesivos de especialización en música (en el orden en que fueron mencionados): en el comienzo -dice-, "sin ninguna duda, los tres fueron uno solo." (p. 4). Partiendo de un supuesto ritual en donde la música era improvisada y los roles no estaban concebidos de la manera en que existen hoy, el rol del compositor emerge como un tipo diferenciado en el momento en que una parte del material

\footnotetext{
${ }^{11}$ Cross sostiene que la música es explicada en situaciones donde el foco está puesto en la interacción social como un fin en sí mismo, un medio de comunicación y filiación entre los miembros de una comunidad. Puesto que su significado es ambiguo, se considera una funcionalidad genérica de la música como medio multimodal para solucionar situaciones de incertidumbre social, el orden social, la formación de la identidad individual y colectiva, etc. La indeterminación semántica presenta a la música como una 'señal honesta'. Se propone la existencia simultánea de tres dimensiones: (i) la estructural-motivacional; (ii) la culturalmente enactiva; y (iii) la socio-intencional. Esto permite a los participantes de un acto musical colectivo dotarla de sus significados individuales y privados al mismo tiempo que se sostiene en la filiación mutua y la sincronización del grupo en el evento colectivo (Cross, 2010).
} 
musical adquiere una forma de organización reconocible que su productor sintió el impulso de repetir. Como consecuencia de esto, el performer surge a su vez como el primer músico que reprodujo esa música compuesta por otro que no era él.

Mientras que el compositor se relaciona de una manera simple, directa y primaria, el performer lo hace de una manera más compleja y problemática, debido a la situación de tener que producir una música que no surge desde su propio impulso. Si bien el pensamiento de Sessions está influenciado por la creación de la música por parte del compositor, plantea este acto "secundario" del performer como una reproducción, donde la música "pasa por el medio de una segunda personalidad, y necesariamente experimenta algo de lo que llamamos interpretación". (p. 6).

El performer para Sessions es quien interpreta y re-concibe la obra, pero además la proyecta (la procesa en función de una ocasión o un evento específico) en un contexto que la condiciona de algún modo, debido a las circunstancias sobre las que tiene lugar. Bajo esta concepción, el oyente representa un estadio tardío del impulso musical; al no participar en la producción de la música, la concibe como un medio de expresión independiente y autosuficiente: "su objetivo ideal es aprehender en su mayoría y en la medida más completa posible la expresión musical del compositor como el intérprete se la entrega (...) Al seguir una performance, la recrea y la hace propia" (p. 8).

Este impulso musical que describe Sessions es un proceso creativo total en el que el compositor, el performer y el oyente cumplen funciones separadas. Esta definición supone para el autor la esencia de la música como actividad: es algo hecho, una experiencia vivida con intensidad variable por el compositor, el intérprete y el oyente por igual. Si perseguimos las fuentes de éste impulso debemos comenzar por el impulso de hacer música: el por qué hombres y mujeres en cada generación se han sentido impulsados a crearla. Los hechos básicos son hechos de la experiencia musical y no los hechos físicos del sonido y el ritmo: "debemos considerar a las fuentes, o materiales crudos, ante todo como hechos humanos" (p. 11).

De este modo, Sessions intenta explicar la experiencia del compositor, el performer y el oyente a través del impulso productor del compositor, en la reproducción real del performer, o en la imaginación del oyente:

...la música es importante para nosotros como seres humanos, principalmente porque encarna el movimiento de un tipo específicamente humano que va a las raíces de nuestro ser y toma forma en los gestos interiores que encarnan nuestras respuestas más profundas e íntimas. Esto todavía no es arte, no es aún lenguaje. Pero es el material del que se compone el arte musical y al cual el arte musical da significado. (...) Los gestos que encarna la música son, después de todo, gestos invisibles; uno puede casi definirlos como consistentes en el movimiento abstracto, movimiento que existe en el tiempo pero no en el espacio, el movimiento, de hecho, que da tiempo a su sentido y a 
su importancia para nosotros. Si esto es cierto, entonces el sonido es su vehículo predestinado. Porque lo que aprehendemos a través del ojo es para nosotros estático, monumental. Incluso el movimiento visto está limitado por nuestra gama de visión; nunca podremos seguirlo de cerca en el espacio a menos que nos movamos. (Sessions, 1950, p. 19-20)

El trabajo del performer comienza entonces con el del compositor, quien organiza los patrones musicales de un modo coherente y traduce la música concebida en símbolos que permiten al performer llevarla a una existencia real y física. La esencia de y la cualidad inherente a la música es inevitablemente producida por el performer: "debido a que es un arte en el cual el tiempo y el movimiento son elementos básicos, requiere de una renovación constante." (p. 70).

La partitura es el enlace entre el compositor y el performer; el primero cuenta con un sistema de notación lo suficientemente desarrollado para indicar al segundo cómo es que su música debe ser tocada. Sessions (1950) dice que los compositores de todos los tiempos demandan a los performers vivacidad o elocuencia, sin embargo:

no han tratado de indicar los factores intangibles en la performance, y al ser hombres con experiencia y sentido común, han sabido muy bien que estos factores, que marcan la diferencia, de hecho, entre una buena performance y una mala performance no pueden ser indicados en ninguna partitura. (p. 73).

En función de recuperar el gesto musical, algo que resulta complejo de plasmar en una partitura, el compositor intenta indicar aquello que representa sus intenciones para la performance de la obra, resultando en un texto complejo. Por este motivo, dice Sessions, la fidelidad al texto del compositor no es una tarea simple: "un gesto, para ser vivo y genuinamente expresivo, debe ser único; debe ir más allá de la mera repetición mecánica y ser investido con una nueva energía si es que debe vivir en el tiempo". (p. 77). De la misma manera un oyente "responderá" a la música recreándola (interna o externamente); a partir de tomarla como algo fresco (recién creado): será capaz de aprehenderla como algo vuelto a crear y no como algo mecánicamente repetido.

Las cuestiones que se dirimen entre la fidelidad al texto y la expresión personal del intérprete son aspectos fundamentales para la valoración de la performance musical y tienen consecuencias en el entramado social que incluye la presentación de las obras y su valoración. Para Sessions, el performer o artista intérprete es el agente que aplica su imaginación al descubrimiento de los gestos musicales inherentes al texto del compositor, lo que de algún modo pone en debate su tarea entre: (i) la posibilidad de realizar una producción fiel a tales intenciones, o (ii) la de producir gestos vivos, con convicción, de manera que puedan ser tomados como un impulso humano. 


\subsection{Síntesis}

El pensamiento acerca de la música en la tradición centroeuropea es consecuencia de un paradigma profundamente arraigado en la música académica y, en menor medida, en otros tipos de música que se reconocen dentro de la misma tradición. Su emergencia en un momento de la historia se debe a un proceso de sistematización de la práctica que finalmente cobra forma como el concepto de obra musical. Para esto, la música debió separarse del significado de la palabra y finalmente encontró su lugar definiéndose en sus propios términos. Como consecuencia, la obra musical se diferenció de la performance y adquirió un grado de racionalización y abstracción que la separó de sus aspectos humanos. En este panorama el compositor se jerarquizó como el creador de la obra, quedando en el extremo racional de la música, mientras que los performers y los oyentes quedaron relegados a una función reproductiva y receptiva, respectivamente: ambos deben responder adecuadamente al modo en el que el compositor creó el objeto musical (uno reproduciendo fielmente la partitura, el otro contemplando el objeto).

La obra musical también puede ser definida desde una perspectiva humana. Si bien la obra alcanza un grado alto de abstracción, la filosofía puede argumentar que no se trata de un objeto ideal. El modo en que se vincula con sus aspectos humanos entiende que la obra es un objeto intencional: que al ser creada por el compositor ocurre en un momento particular y que sus propiedades pueden ser sujetas a una verificación interpersonal. Esta inferencia se lleva a cabo a través de sus objetos reales: las partituras y las performances, que ocurren en un espacio y un tiempo determinados. Flnalmente, como objeto intencional, la obra musical se define en las intenciones de los seres conscientes (los humanos).

Los roles sociales de la música (el compositor, el performer y el oyente) pueden ser definidos de manera unificada debido al impulso musical. Visto de este modo, cada uno desde su rol particular contribuyen al proceso de la práctica musical y le dan sentido a la participación de los demás.

En esta tesis indagamos la participación de los agentes sociales desde la perspectiva del performer, entendiendo que su participación en la música requiere establecer vínculos con el compositor y el oyente a través de la obra. Sin embargo, su rol social es entendido en un "proceso" que no finaliza en el "producto" de la obra, sino que puede requerir partir desde lo finalizado por el compositor, o bien continuarlo desde donde el compositor lo dejó. 


\section{CAPÍTULO 2}

Concepciones acerca de la performance

Obra, texto, interpretación

En este capítulo abordamos el estudio y el conocimiento desarrollado acerca de la performance musical a partir de los modelos que la definen; en su práctica, su investigación y su análisis.

Introducimos a la performance musical con algunas concepciones generales sobre la práctica, los temas y enfoques de estudio para su investigación; y un recorrido histórico acerca de la relación entre el compositor, el performer y la partitura. A continuación, definimos a la performance musical en el marco del paradigma de la performance clásica, según es entendido por la filosofía de las artes performáticas.

El concepto de interpretación es abordado como una instancia entre el compositor y el performer, que en música se refiere a la relación entre la partitura y la performance. En el arte performático, la interpretación implica cuestiones referidas al texto y al acto que suponen posiciones contrapuestas: por un lado, desde el modelo que entiende a la performance como subordinada a la obra de arte, se reclama el deber de la fidelidad hacia la obra; por otro lado, desde la posición que entiende a la música como un arte performático, se considera que la obra solamente es repetible en su organización composicional, siendo la performance una obra única o una instancia única de la obra. Por lo tanto, en el primero el performer no debe interponerse entre la obra y el público; mientras que en el segundo, se acepta la creación o recreación de la partitura por parte del performer como un aporte a la obra.

\subsection{La performance como disciplina musical}

\subsubsection{Concepciones acerca de la actividad del performer}

Como hemos visto, el concepto de performance musical en la cultura occidental se define en relación a una obra preexistente, compuesta y escrita en una partitura. Una performance también puede ser definida en términos de una habilidad humana, donde el músico es capaz de producir los sonidos necesarios (cantando o tocando), además de conocer la obra y poder leer la escritura. Sin embargo, aquellos 
que estudian la performance musical sostienen que la partitura no es la obra en sí, y que la idea de llegar a serle "fiel" no es realmente posible, aún cuando el performer tenga toda la intención de hacerlo.

Una performance de música clásica lleva implícita la idea de un evento específico, que ocurre en un lugar determinado, y la realización de la obra para un público que asiste con la intención de formar parte de dicho evento. Como experiencia, el músico y el público cumplen roles específicos y diferenciados: el músico cumple el rol de producir la obra en sonido, mientras que el público recibe la obra a través del músico. En la actualidad, en una performance de música clásica, el compositor puede no estar presente en la sala, puede ser o no performer de su propia obra; en éste modelo de producción y presentación de obras musicales se considera que ya ha terminado su trabajo, y una vez producida la partitura no requiere de una participación obligatoria. $^{12}$

Como arte musical, la producción sonora del performer es considerada como el contenido indispensable para que la performance sea llevada a cabo. Como experiencia sonora, la música adquiere su materialidad física a través del performer, quien procede a partir de las indicaciones que el compositor escribió en el papel. Debido a esto, la interpretación es vista como "una transformación de la partitura en un evento musical único" (Rink, 2002, p. xii).

El performer (músico cantante o instrumentista encargado de realizar una performance) realiza una serie de actividades sobre la obra que se sustentan en la partitura; esto beneficia la visión de la obra como una totalidad, y permite realizar una planificación con el objetivo de llevarla a cabo. Las actividades que están implicadas durante la preparación de la performance incluyen la lectura del texto, una interpretación comprensiva de los signos escritos en el tiempo, el análisis de la obra, la práctica técnica y el ensayo. La performance es considerada como una actividad de alto rendimiento, que incluye la coordinación de las acciones necesarias para su ejecución, un plan de acción para la realización completa de la obra y un grado especial de concentración. Rink (2002) dice que se considera que la práctica o el estudio "es una actividad generalmente solitaria, totalmente opuesta a la interpretación como experiencia sumamente social" (p. xii).

Small (1998) propuso un punto de vista diferenciado y más comprometido con la performance: "la performance no existe para presentar obras musicales, sino que

\footnotetext{
12 En la actualidad, ésta practica continúa y convive con otras practicas posteriores y actuales. Estas nuevas prácticas difieren mucho de lo que aquí estamos describiendo; existen muchas formas de crear y presentar obras musicales, y no todas son posibles de ser clasificadas con facilidad. Nosotros describimos el pensamiento desarrollado en el contexto de la música occidental académica de acuerdo a los fines de este estudio.
} 
las obras musicales existen para darles a los intérpretes algo que performar." (p. 8). Concentrarse en la obra musical no permite ver el conjunto de relaciones que constituye una performance. Para el autor, la música ha sido vista como un asunto de la obra y su efecto en un oyente individual; sin embargo, los significados de la música no son para nada individuales sino sociales. De este modo, el significado se encuentra en la acción, lo que la gente hace cuando participa de un acto musical; esto es algo tan importante para la humanidad como lo es el acto de hablar, al que se parece pero también difiere de manera importante (Small, 1998).

\subsubsection{La investigación de la performance musical}

La performance musical comprende un campo amplio de estudio que se lleva a cabo desde diferentes enfoques. En este apartado haremos un breve recorrido para dar cuenta de algunas de las investigaciones más importantes acerca de la performance instrumental del repertorio académico occidental.

El estudio empírico de la performance significó un cambio en el ámbito de la musicología, que pasó del análisis de las partituras y borradores escritos hacia la performance en sí misma como un objeto de estudio. Los avances tecnológicos permitieron en el siglo XX la documentación y grabación de las performances para su estudio, en registros de sonido y movimiento. Una buena parte de las investigaciones se realizaron en colaboración con otras disciplinas como las ciencias cognitivas y la psicología (Clarke, 2004).

Seashore fue el primero que desarrolló técnicas para grabar la performance en detalle y analizar, entre otras cosas: (i) cuestiones de tempo y dinámica; (ii) la precisión y reproductibilidad de la interpretación; y (iii) la producción y control de los sonidos (Seashore [1938] 1967). Luego, en un nuevo período de la investigación en el tema, se realizaron por primera vez estudios acerca del timing expresivo (Bengtsson y Gabrielsson, 1977; Povel, 1977). La coordinación de los movimientos en la performance se investigó en base a una teoría de la programación motora, y se concentró en aspectos vinculados al tempo, la coordinación, la expresión y la representación cognitiva de los movimientos (Shaffer, 1981). Los estudios continuaron con el análisis de un gran conjunto de datos sobre grabaciones comerciales de performances, lo que permitió comparar diferentes interpretaciones de una misma obra (Repp, 1990). Se estudiaron también aspectos relativos al componente visual de la performance en los movimientos que realiza el músico (Davidson, 1993). Finalmente en el año 1995 se realiza la primera gran publicación acerca de la performance musical, reuniendo a musicólogos y psicólogos investigadores en el tema (Rink, 1995). 
La expresión en la performance como tema de investigación es entendida como las variaciones grandes y pequeñas en el timing, la intensidad o la dinámica, el timbre y el tono que forman la microestructura de una performance y que la pueden diferenciar de otra performance de la misma obra. A menudo, la expresión se analiza de acuerdo a la desviación de los eventos realizados con respecto de sus valores fijos o regulares que se anotan en la partitura (Gabrielsson, 1987).

Algunos otros temas abordados en este período se vinculan con la planificación y otros aspectos específicos de la performance como la lectura a primera vista, la improvisación y la retroalimentación; además de los aspectos físicos, psicológicos, y la evaluación de la performance (Gabrielsson, 1999). La incidencia de los factores sociales en la performance han sido estudiados desde el desarrollo de la habilidad (Sloboda y Howe, 1991, 1992), la personalidad, la práctica profesional y la ansiedad en la performance (Gabrielsson, 1999).

Más adelante, los nuevos avances en el estudio de la performance cambiaron el foco de la investigación en la interpretación individual hacia el estudio de grupos de músicos. Por otro lado, el desarrollo de la tecnología permitió registrar y analizar digitalmente el movimiento con sistemas de captura que utilizan pequeños marcadores sin cables (Mocap) (Martínez, Damesón, Pérez, Pereira Ghiena, Tanco y Alimenti Bel, 2017; Naveda, Martínez, Damesón, Pereira Ghiena, Herrera y Ordás, 2016; Tanco, Martínez y Damesón, 2015). Abandonando la separación entre mente y cuerpo de la filosofía cartesiana, las investigaciones en música se involucraron con las ideas de la segunda generación de las ciencias cognitivas de la música, un amplio conjunto de disciplinas que promovió el estudio de la música rescatando sus aspectos corporeizados, situados y anclados para la significación de la música en la experiencia (Leman, 2008; Martínez, 2008a; Martínez, 2008b).

\subsubsection{La relación entre el compositor, la partitura y el performer a lo largo de la historia}

La composición de la música supone un conjunto de actividades como hacer, recordar, repetir y escribir la música; mientras que el concepto de compositor involucra además la idea de autoría de la obra. Sin embargo, no existen pruebas de la existencia de un término en ningún idioma que lo designara antes del siglo XVI (Kivy, 2001). Mientras que la actividad del performer en la música occidental académica es generalmente considerada como la reproducción "fiel" de la partitura, a lo largo de la historia las condiciones de la práctica, así como las de la relación entre el compositor y el performer, fueron variando dependiendo del contexto y el período musical. 
Entendida como un registro para recordar la música, la partitura determina inicialmente un tipo de relación entre el compositor y el performer. En la actualidad, tocar la música de compositores como Mozart o Beethoven -que vivieron en el pasado- asume el hecho de que el compositor esté ausente. Sin embargo, al indagar en la historia, podemos ver que la partitura no siempre implicó la ausencia del compositor. Mozart solía presentarse en público para interpretar conciertos para piano de su autoría, cumpliendo ambos roles de compositor e intérprete. Beethoven también dirigió varias de sus obras orquestales durante sus presentaciones en público. En el barroco, la música de cámara a menudo era dirigida por el compositor desde el clave, por lo cual las indicaciones interpretativas en detalle no se consideraban necesarias. De un modo similar, la partitura barroca no contenía todas las notas del continuo, y entonces la música debía ser interpretada a partir de un modo más esquemático de escritura (Lawson, 2002).

Hasta mediados del siglo XIX se daba por sentado que el intérprete debía poder improvisar, algo que en las obras ocurría con frecuencia. También era costumbre que se adaptaran las partituras para la ocasión, dependiendo de los requerimientos de la performance: aunque la notación se encontrara sobre el atril, los intérpretes adoptaban la partitura con un enfoque libre y creativo. Como un acontecimiento histórico, las partituras comenzaron a difundirse ampliamente en el siglo XIX, donde las indicaciones escritas comenzaron a ser más precisas. En el siglo XX la notación musical se extendió: algunos compositores de música contemporánea incorporaron usos no convencionales de la notación, inspirando la improvisación de los performers en las prácticas interpretativas (Lawson, 2002).

A partir de 1940 la música podía ser grabada y ser trasladada para su reproducción, un desarrollo tecnológico que le permitió a la música insertarse en el mundo laboral, comercial y financiero de la época. Desde entonces hasta la actualidad, los avances en la grabación incorporaron nuevos y mejores dispositivos de registro y difusión de las obras (vinilos, cassettes, cds, mp3, etc.) que junto a los medios de comunicación (radio, televisión) y las plataformas de la era digital (internet, redes sociales) ampliaron los horizontes de acceso a la información y la presencia de la música en la vida cotidiana, tanto para el público como para los performers.

\subsection{La música como arte performático}

En términos generales, la performance $\operatorname{artística~}^{13}$ es un arte que involucra una corporalidad y una presentación ante el público, quien participa en la recepción de una obra performada en el mismo momento en que es creada. Uno de los aspectos

\footnotetext{
${ }^{13}$ Se refiere a un conjunto de disciplinas que incluyen a la música, la danza y el teatro.
} 
principales de las performances es su naturaleza temporal: la obra no se constituye como un objeto estático ante el espectador, sino que transcurre a medida que se desarrollan las acciones del performer y finaliza (o desaparece) cuando se ha producido la última acción.

Al decir que una performance consiste en una serie de acciones, no se considera que todas las acciones humanas puedan ser entendidas en términos de una performance artística. Para esto, el performer debe ser conscientemente guiado por esas acciones y por la evaluación anticipada de una audiencia hacia la cual se tiene la intención de realizar la performance. En la práctica, la organización de la performance no es la composición de sus elementos particulares en el modo en que están puestos juntos, sino cómo el ensamblado de los elementos que conforman el "vehículo artístico" son intencionados para funcionar en la articulación del contenido (D. Davies, 2011).

En esta tesis abordaremos aspectos de la música como arte performático, siguiendo al paradigma clásico de la performance que desarrollaremos a continuación.

\subsubsection{El paradigma clásico: tipo y caso}

La música como arte performado ${ }^{14}$ consiste -según el paradigma clásico- en la presentación de una obra independiente (la composición). En este paradigma, se considera que la performance es requerida para que las cualidades de la obra sean apreciadas en los términos de lo que la obra es, y para que esta actuación vuelva a la obra realizable y accesible al público.

En este contexto, la obra de arte es una obra performada y como tal, llama a la interpretación de parte de el/la/los/las performer/s. El público, por su parte, llega al lugar del evento con ciertas expectativas: espera que cada performance revele nuevas posibilidades de la obra. A su vez, la performance es evaluada por el público en relación a otras performances a las que han atendido previamente.

La obra performable ${ }^{15}$ se explica a través de la distinción entre tipos y casos: una obra independiente (la obra performable) es el tipo y su performance, un caso. Para ejemplificarlo se puede considerar una distinción entre la música y el cine: un espectador que asiste por segunda vez a la presentación de una obra musical conocida será el receptor de un nuevo caso (la performance) del mismo tipo (la obra independiente que ya conoce), mientras que el espectador de cine que asiste por

\footnotetext{
${ }^{14}$ También llamado arte performático, es una categoría asignada a un conjunto de artes entre las que se encuentran principalmente la música, la danza y el teatro.

${ }^{15}$ Es una obra que puede ser performada, presentada en una performance.
} 
segunda vez a la proyección de un film volverá a ser receptor del mismo caso (el film que ya vió). ${ }^{16}$

En una performance en vivo, la obra musical como entidad es repetible únicamente en el sentido en que puede ser performada en más de una ocasión, lo que no equivale a decir que la performance sea repetida. Una característica esencial del concepto de obra performable (una obra que puede ser performada) es que ésta puede ser apropiadamente apreciada, o bien, apreciada completamente a través y sólo a través de las performances, lo que establece una relación íntima entre ambas. Sin embargo, la obra performable es una obra independiente porque seguirá siendo la misma en cada performance.

No todas las instancias de performance son consideradas performances válidas de la obra: se dice que una performance incorrecta no representa a la obra. Para esto, el compositor de una obra de musical del paradigma clásico provee a través de la partitura instrucciones que sirven para generar múltiples instancias de la obra. Las relaciones entre la partitura, la interpretación y las performances musicales serán desarrolladas más adelante en este capítulo.

\subsubsection{Variedades de las teorías de tipo}

A continuación nos ocuparemos de las características que las obras performables deben cumplir para ser consideradas como performances bien formadas. En música se reconocen tres criterios: el sonicismo, el instrumentalismo, y el contextualismo.

El sonicismo considera válida a una performance siempre y cuando mantenga su apariencia a partir de las cualidades acústicas de la obra. La naturaleza de esas condiciones acústicas es en parte identificable con los caracteres escritos en la partitura (notas, alturas, duraciones y ritmos). Se distingue dentro de este criterio entre los sonicistas puros y los sonicistas tímbricos; éstos últimos son quienes consideran, además de sus propiedades estructurales, a sus propiedades tímbricas.

El instrumentalismo considera que la performance correcta de una obra no solamente debe cumplir con las propiedades sonoras, sino que debe ser performada con los instrumentos prescritos en la partitura. ${ }^{17}$

El tercer criterio, el contextualismo, considera que una parte importante de las propiedades del producto artístico -que deben ser comprendidas para apreciar la obra de arte- no dependen de la secuencia de eventos que prescribió el compositor. En

\footnotetext{
${ }^{16}$ Esto no quiere decir que el receptor vuelva a tener la misma experiencia.

${ }^{17}$ Para los sonicistas tímbricos, la performance podría realizarse con cualquier instrumento que produzca el sonido correcto, como sería el caso de un sintetizador que produzca el mismo sonido "a la perfección".
} 
cambio, establece otro tipo de criterios vinculados a su significado: la identidad de la obra performable y del contexto artístico-histórico en el que el artista trabajó. El contexto en este sentido incluye a las propiedades estéticas (que se experiencian como una abstracción, que a su vez permite compararla con otras obras) y a las propiedades artísticas (que relacionan a la obra de manera más explícita con su contexto artístico-histórico).

Estos tres principios presentan criterios diferentes para poder considerar performances bien formadas $y$, por lo tanto permiten identificar a una performance (un caso) con una obra (un tipo). Debido a las propiedades que diferencian a los tipos y casos, la identificación no puede producirse de manera inversa: una obra (tipo) no puede ser identificada con una performance particular (un caso). Al preguntarse qué tipo de propiedades artísticas pueden compartir un tipo y un caso, David Davies (2011) dice que pueden ser entendidas como análogas en sus propiedades apreciables.

\subsubsection{La performance como 'lo inimitable'}

Goodman (1976) introduce -en la discusión acerca de la validez de una performance musical- el concepto de falsificación, característico de algunas formas de arte como la pintura. Su consideración parte del hecho que una falsificación se presenta a la percepción como exactamente igual a su original, y que su falsedad en estos casos sólo puede comprobarse fehacientemente con métodos que implican un análisis detallado (exámenes microscópicos y análisis químicos). Para entender esto, Goodman define a la pintura como un arte autográfico, lo que implica que la finalización y el producto de una obra son realizados por el pintor en una única etapa, y que su autenticidad se sustenta en que sea la misma obra realizada por él.

La música, en cambio, no es un arte autográfico (es no autográfico o alográfico): el compositor finaliza la obra con la realización de la partitura pero su producto final ocurre en la instancia de la performance (según Goodman, en la música se realiza en tres etapas).$^{18}$ El conjunto de caracteres que determina la partitura de una obra puede ser transcripto de manera correcta en una nueva partitura, manteniendo los requisitos para ser considerada como un ejemplar auténtico de la obra. Sin embargo no ocurre lo mismo con su performance; la ejecución correcta no depende únicamente del conocimiento del alfabeto:

...las ejecuciones que se adecúan a la partitura pueden diferir considerablemente respecto de rasgos musicales tales como el tempo, el timbre, la melodía y la expresividad. Determinar su adecuación requiere (...) la

\footnotetext{
${ }^{18} \mathrm{Si}$ consideramos que una obra literaria se concreta en dos etapas, siendo la primera la realización del texto y la segunda su lectura silenciosa, entonces deberíamos considerar que la música se realiza en tres (implica a la performance).
} 
capacidad de correlacionar los sonidos apropiados con los signos visibles en la partitura, reconocer, por así decirlo, la pronunciación correcta, aun cuando no necesariamente se comprenda lo que se pronuncia. (...) Ninguna información histórica relativa a la producción de la ejecución puede afectar el resultado. Por lo tanto, el engaño acerca de los hechos de la producción no es pertinente, y la idea de una ejecución que constituya una falsificación de la obra no tiene sentido. (Goodman, 1976, p. 117-118).

Las performances musicales -dice Goodman- pueden variar respecto de su corrección y calidad, e incluso respecto de una 'autenticidad' de tipo más esotérico; pero mientras mantengan su correspondencia con la partitura, todas las ejecuciones correctas son instancias igualmente genuinas de la obra: no hay nada en música que se conozca como la falsificación de una obra. En cambio, en la pintura "La falsificación de una obra de arte es un objeto que falsamente pretende tener la historia de producción exigida para el (o un) original de la obra." (p. 122).

Introduciendo un criterio de autenticidad que proviene de la disciplina artística (en este caso, la pintura), Goodman desafía la posibilidad de intentar una distinción entre performances auténticas o falsas de una obra musical, siempre y cuando sean ejecuciones correctas de la partitura. Estas consideraciones nos permitirán entender, unos párrafos más adelante, la discusión existente en la práctica de la performance musical respecto al movimiento de las performances históricas.

Hemos visto que desde la performance musical la obra es considerada como tal una vez que es consumada o presentada en sus propiedades sonoras. En este proceso, el compositor es el que realiza la composición o el "tipo" que permite presentar la obra en una serie de "casos", en la medida que cumpla con los requisitos que permitan considerarlos como tal. Desde esta perspectiva, según Goodman, el compositor finaliza la obra, pero su "producto" como estado final ocurre en la performance. Desde esta postura, lo "autográfico" como algo que pertenece al compositor es desafiado por la visión de Goodman en relación a la "historia de su producción". Sin embargo, existe un conflicto en relación a la comparación entre lo autográfico en la pintura y la música, siendo que en esta última se reconoce que la autoría de la obra pertenece al compositor. Más allá de esta observación, lo relevante para señalar aquí es que la "autenticidad" de la performance es cuestionada en relación a la "producción" de una obra: el performer es considerado como una parte importante constitutiva del proceso de producción de la obra, y su "producto" final.

\subsection{La interpretación musical}

El término interpretación es frecuentemente utilizado como un sinónimo de la performance, esto puede verse sobre todo en las traducciones de libros del idioma inglés al castellano. Sin embargo, como veremos a continuación, esta idea de concebir 
a ambas como sinónimos satisface solamente las expectativas de compositores y teóricos de la música, quienes consideran que todo lo que debe hacerse en una performance está prescrito en las instrucciones de la partitura. En su lugar, la interpretación se presenta como un proceso entre la obra y la performance que se vincula con la notación de la partitura, y que es llevado adelante por quien comanda la performance (según sea la práctica: el/la/los/las performer/s, el director, e incluso el compositor mismo), tomando decisiones a partir del texto para entender cómo la obra adquiere su 'materialidad' en sonido y movimiento, para luego llevarla a cabo en la performance.

Para comprender en qué consiste la interpretación debemos considerar en principio que la partitura permite establecer algunos de los parámetros de la obra, que no puede contener toda la información que se pone en acción en la performance, y que esto se debe a que la notación puede establecer valores absolutos/objetivos en la escritura que sin embargo pueden expresarse de diferente modo en cada estilo musical. Esto es similar a lo que ocurre con la relación entre el texto y el habla en el lenguaje: "así como la pronunciación y los significados de las palabras cambian con el tiempo, la notación musical aparentemente estándar tiene significados sutilmente diferentes dependiendo de dónde y cuándo fue escrita." (Walls, 2002, p. 18).

Las posiciones con respecto a la interpretación de las obras se dividen entre aquellos que: (i) entienden que la obra es la reproducción de los sonidos de la partitura, y por lo tanto los performers no deberían interponerse; (ii) consideran que la partitura implica una interpretación, y que ésta puede ser correcta o incorrecta; (iii) sostienen que cada interpretación puede revelar aspectos nuevos acerca de la obra, y por lo tanto consideran a la tarea creativa de los performers como un valor positivo.

Con respecto a la notación musical, hemos visto que puede ser tomada en sí misma como un instrumento de variable contextual, desde el momento en que sabemos que la notación en cada época mantuvo una relación íntima con respecto a la performance. Leer o interpretar una partitura implica entonces tomar un punto de vista con respecto al tipo de notación y su performance, lo que inhabilitaría la posibilidad de una significación neutra de los signos escritos en la partitura, o incluso la de una interpretación neutra (sin expresión) como una actitud que sea aplicable a los textos de todas las épocas (sin estilo).

A pesar de las posibilidades tecnológicas con las que contamos hoy para la grabación y reproducción de las obras (en sonido y video), estos avances no llegaron a tiempo para recuperar toda la música del pasado $(\text { Cook, 2013) })^{19}$. Si contáramos con

\footnotetext{
${ }^{19}$ Cook dice: “...tenemos muy poca idea de cómo sonaba la música antes del desarrollo de la grabación.” (Cook, 2013, p. 3).
} 
las grabaciones originales de los compositores o las de los primeros intérpretes de las obras, la discusión seguramente sería otra. Sin embargo, en cierto sentido, las condiciones actuales podrían beneficiar la interpretación del texto musical, debido a que contamos con un fácil acceso a grabaciones de otros intérpretes que las realizaron anteriormente. En el sentido contrario, las grabaciones de otros intérpretes podrían desalentar la práctica interpretativa, porque "si nos limitamos a copiar la manera en que otros tocan, estamos admitiendo que lo que nosotros podemos ofrecer es de segunda categoría." (Hill, 2002). Los performers también cuentan hoy con la influencia del trabajo de los analistas y teóricos que a través de los textos musicales recuperan o resignifican la interpretación.

Lo anteriormente mencionado expone cómo la performance moderna o contemporánea presenta hoy una distancia histórica entre una parte del repertorio y su práctica: mientras que los compositores ya no están disponibles, los performers y el público pertenecen a otro contexto. A lo largo de los años, la performance musical ha ido cambiando algunos criterios acerca de lo que la 'fidelidad a la obra' significa, dando surgimiento a movimientos que ponen en valor la performance históricamente informada y la autenticidad de la performance, basados en documentos escritos y manuscritos originales de las obras.

La noción de autenticidad histórica surge en el arte como una consideración hacia las cosas que se proponen como instancias de una obra. Mientras que en la pintura una obra se considera auténtica por ser realizada por la mano del pintor, en las artes múltiples (que presentan múltiples instancias de las obras, como la performance) la autenticidad es entendida de modo análogo. En este sentido, en el arte musical, la frase 'ser fiel a la obra' puede entenderse de tres maneras: (i) ser fiel al compositor implica reconocer su involucramiento en la obra y entonces interpretar sus intenciones y deseos de cómo debería ser tocada la obra; (ii) ser fiel al sonido implica reproducir la secuencia de sonidos de la mejor manera posible (su secuencia de sonidos, su timbre, su pureza sonora); y (iii) ser fiel a la práctica de la performance implica realizar la obra de acuerdo a las prácticas vigentes al momento en que la obra fue compuesta (D. Davies, 2011).

\subsubsection{La performance como reproducción, el performer como mediador}

La mayoría de las ideas que se discuten en relación a la performance de una obra se vinculan con el deber del performer hacia la obra. La escritura acerca de este tema de debate es extensa, e incluye las opiniones de los compositores acerca de las interpretaciones de sus obras. Se debaten posiciones a favor y en contra acerca de la libertad de los músicos al tocar las obras de una u otra manera, argumentando cierta 
falta de respeto hacia la música. Nosotros sin embargo no conocemos las performances a las que se refieren estos compositores, pero conocerlas seguramente nos permitiría entender más. En todo caso, debemos considerar que estas opiniones se proponen realizar una distinción entre performances buenas y mediocres. ${ }^{20}$

Algunas opiniones de los compositores llegan a nosotros a través de sus propios escritos o en libros que abordan la performance musical. Por ejemplo, Ravel afirmó: "No pido que mi música sea interpretada, sino solamente ejecutada", mientras que Stravinsky dijo "La música debe ser transmitida y no interpretada, ya que la interpretación revela la personalidad del intérprete en lugar de la del autor" (en Walls, 1995). Varias de estas opiniones se basan en que lo importante de una obra ya está presente en la escritura; por ejemplo Arnold Schoenberg dijo que "el intérprete es totalmente innecesario, salvo que sus interpretaciones hagan que la música sea comprensible para un público lo suficientemente desafortunado como para no poder leerla impresa", mientras que Rudolf Kolisch sostuvo que "toda la necesidad de una performance desaparece si uno puede leer música" (en Cook, 2013).

En vistas de la posibilidad de desviar el contenido de la partitura en función de lo que la obra es, lo que estos los compositores estarían manifestando se vincula con lo que se entiende como el rol del performer como mediador (Cook, 2013), un intermediario cuya obligación es la de presentar la obra al oyente, y que a su vez conlleva la obligación del oyente a esforzarse en comprender la obra de un modo adecuado. Si el performer debe entregar al público sólo lo que ya está en la composición (la partitura), esto implica que no exprese sus opiniones sino que haga la tarea de un ventrílocuo, cumpliendo con la idea de la performance como reproducción (Cook, 2013).

Este tipo de "ventrilocuismo" supone que el performer no debe interponerse entre la obra y el público, o entre el compositor y el público para dejar que la música "hable por sí misma" o que el compositor "hable por sí mismo". La distinción entre texto y acto plantea dos maneras de concebir a la obra musical; fue puesta en debate por Taruskin (1995), quien rechazó la posición del textualismo argumentando que "la fuente del error es la confusión de un objeto físico (el texto) con un acto (la performance) y una idea (la obra)." (p. 39).

20 Walls dice que los compositores: "Se quejaban, claramente, de las interpretaciones voluntariosas en las que destacan los caprichos de los intérpretes que no se justifican de ninguna manera en la partitura." (Walls, 1995, p. 17) 


\subsubsection{El texto musical}

El texto musical es una forma escrita o impresa que contiene una información codificada de la música en signos que refieren a los diferentes parámetros musicales que codifica. La partitura se compone con códigos precisos que indican los eventos en el pentagrama (altura, duración), mientras que otros elementos de la notación son instrucciones vagas como pueden ser las de las dinámicas, el tempo y los signos de articulación (Boorman, 1999).

En relación a la performance, el texto puede ser entendido en el sentido de cumplir la función de presentar los eventos que deben ejecutarse en una reproducción de la obra, así como ocurre con la información que ingresa en un sistema que reproduce la música (el rollo de una pianola, el sistema midi o un software informático). En otro sentido, el texto puede ser entendido como una referencia escrita que codifica los parámetros objetivos en relación a un conjunto de reglas propias del sistema de notación, pero que en relación a la obra debe ser visto como una representación aproximada, debido a que la escritura presenta limitaciones para codificarla.

El texto como forma escrita de registro fue, en un momento determinado de la historia, necesario para conservar las obras; sin embargo hoy contamos con otros medios que pueden reemplazar esta función, como es el caso de las grabaciones. La forma escrita supone una organización basada en cuestiones específicas de la ejecución instrumental o vocal, y por lo tanto establece una relación particular con la práctica del performer. Se pueden diferenciar entonces cuestiones de uso y función en la escritura: mientras que la relación entre el texto musical y la obra es una preocupación del musicólogo, el performer considera al texto en la relación entre obra y performance.

Según Hill (2000), las partituras contienen información musical que es en parte exacta y en parte aproximada, a la cual suelen añadirse indicaciones sobre cómo puede interpretarse esa información, pero "la música misma es algo imaginado, en primer lugar por el compositor, después en asociación con el intérprete, y finalmente transmitido en sonido." (p.155).

El texto musical entonces establece una relación con la obra que codifica, mientras que, en relación a la performance, establece otra. Por otro lado, como todo texto, el musical no solamente implica aquello que codifica, sino también en qué modo se realiza la lectura de lo que codifica. Esto se debe a que "ninguna anotación práctica ha sido (o ha sido concebida para ser) integral o precisa. Cada notación, y cada fuente que la usa, asume una serie de interpretaciones por parte del lector." (Boorman, 1999, p. 408). Las notaciones son imprecisas porque ocultan algunos elementos, omitiendo gran parte del texto "real" de una composición. Cada notación arregla una versión de 
la pieza para el lector: como guía para la performance, puede omitir ciertas informaciones que son bien entendidas por el performer en relación al estilo y su presentación en un evento determinado. Por lo tanto, "el texto no lleva más que la información mínima necesaria para una nueva performance. No es la composición misma” (p. 406).

La transmisión de la música a través de la escritura responde a necesidades específicas. La escritura musical cumplió la función de diseminar un grupo de piezas cuando la transmisión verbal no era lo suficientemente precisa; hace mucho tiempo, los monjes viajaban con los manuscritos de piezas de canto gregoriano hacia cada lugar, pero más tarde éstos comenzaron a enviarse sin acompañantes, por lo que los cantantes los leían de acuerdo a su comprensión personal de las convenciones. Las deficiencias en el texto escrito fueron vistas como oportunidades que dieron surgimiento a características locales de interpretación en cada lugar. Los artistas por lo tanto esperaban y aprovechaban esas libertades en la interpretación, lo que dio lugar a la escritura de tratados que favorecieran este tipo de habilidades. En la actualidad, en cambio, la performance contemporánea presenta diferentes circunstancias a las que existían en otras épocas. Hoy contamos con fuentes diversas: manuscritos originales, transcripciones, copias y ediciones que suponen diferentes fuentes escritas para la preparación de una performance. Boorman (1999) afirma que "El texto musical escrito o impreso es un objeto del que se debe desconfiar en todo momento" (p. 403), debido a que: (i) algunos editores suelen agregar información "no original" a las partituras; y que (ii) en las ediciones Urtext los editores dicen haber eliminado todas los adicionales posteriores a la producción del texto musical. En ambos casos esto implica que el usuario deposite su confianza en el texto, mientras que por otro lado involucra la confianza personal que tiene el editor para considerar que las decisiones que finalmente toma se realizan de acuerdo a los criterios 'correctos' (Boorman, 1999).

La notación de la música occidental es un sistema que fue cambiando y adaptándose de acuerdo a las épocas y las necesidades. En el siglo XX, advirtiendo que la escritura era imprecisa para definir las performances que realizaban los músicos, los compositores aplicaron criterios más específicos de notación con la intención de determinarlas. En ese mismo contexto se produjo también uno de los momentos de mayor tensión en la relación entre el compositor y el performer, debido a los criterios de pertinencia entre una interpretación y su obra.

En el ámbito de la performance de la música occidental, si un músico cambiara algunas notas sería motivo para la descalificación de la performance. Dadas las características actuales de la escritura musical, la correspondencia nota a nota del texto es una de las condiciones fundamentales para la validez de la performance. 
Peter Kivy (2001) afirmó que una correspondencia nota a nota entre la partitura y su performance depende de su contexto histórico, ya que dicha correspondencia era entendida de diferentes maneras en cada época. Los cambios en la notación respondieron a nuevas necesidades entre la obra y su interpretación, algo que no debería entenderse en términos de desarrollo porque "aunque la finalidad general de la notación sea hasta cierto punto facilitar la repetición de lo repetible, no es una buena idea pensar que las notaciones son cada vez más eficaces en este sentido" (p. 26).

En la ontología de la proto-obra/interpretación, que implica lo que Kivy llama lo repetible y la repetición, todas las notaciones son efectivas en la medida que "definan por completo la interpretación; $y$, en realidad presenten instrucciones precisas para la producción del sonido" (p. 26). Esto incluye también a las partituras de obras barrocas -donde se dejan abiertas muchas de estas especificaciones- ${ }^{21}$ y de otras obras que plantean una relación diferente entre partitura e interpretación; en tal caso: "cualquier interpretación correcta de esa notación es, según el único modelo lógico, la repetición nota a nota" (p. 27).

\subsubsection{La música como performance y las grabaciones}

La idea de la música como performance ha sido propuesta por Nicholas Cook (2001, 2003), motivado por el intento de cambiar el objeto musical desde la perspectiva de la musicología (una disciplina organizada alrededor de la idea de la música como escritura). Pensar en la música como escrita es ver su significado como inscripto dentro de la partitura, y del mismo modo ver a la performance como la reproducción de su significado. Esto convierte a la performance en una especie de suplemento de la música en sí, un extra opcional, lo que se denomina escritura en sonido o escritura sonora (Cook, 2013). ${ }^{22}$ Uno de sus argumentos principales del autor considera que la experiencia de la música en vivo o grabada es una forma primaria de la experiencia que tenemos con la música y que los performers hacen una contribución indispensable a la cultura de la práctica creativa que es la música. Otra de sus motivaciones reside en el modo particular en el que los estudios interdisciplinarios sobre la performance consideran la relación entre el texto y la actuación en el teatro.

Cook otorga mayor importancia al significado en sonido de la música, motivo que lo acerca a valorar las grabaciones sonoras. Según el autor, escuchamos a las grabaciones como performances: "incluso cuando sabemos que la interpretación

21 "Es decir, la partitura moderna determina los sonidos que se producirán durante la interpretación con mayor precisión que, por ejemplo, la partitura de una sonata para violín y bajo cifrado de Bach" (Kivy, 2001, p. 26).

${ }_{22}^{2}$ En el original sounded writing, se refiere a textos que son reproducidos sonoramente en la performance. 
representada por la grabación nunca tuvo lugar. Escuchar una grabación es, por lo tanto, experimentar la música como performance" (Cook, 2013, p. 6). El fenómeno de las grabaciones es un caso particular en la industria: los productores de las grabaciones pretenden reproducir la experiencia de la música escuchada en vivo, mientras que al mismo tiempo la música en vivo se parece cada vez más a la experiencia de escuchar una grabación.

Pensar la música como performance implica volver a considerar el estudio de la música desde la performance. Esto no implica mantener la misma lógica de pensamiento y la actitud hacia el texto cambiando únicamente el objeto de estudio: mientras que para la música como texto el significado se encuentra dentro de la partitura, para la música como performance, lejos de ser una reproducción de ese significado, implica que existe un significado que es creado en el acto de la performance: "solo una vez que empezamos a pensar en la música como performance es que podemos comenzar a hacer sentido de las partituras." (Cook, 2013, p. 1).

\subsubsection{La performance más allá de la partitura}

Si aceptamos el modelo de tipos y casos que propone la teoría de la performance o si vemos a la obra como un objeto ideal, estaríamos en principio aceptando que ninguna performance como objeto real puede ser igual a la obra (un caso no puede ser igual a un tipo). El concepto de obra, como Lydia Goehr lo sostiene, sigue hoy en día tan presente como en el momento de su surgimiento (Goehr, 1992), por lo tanto el deber del músico y de la performance sigue siendo hacia la obra. Mientras que las obras del pasado sigan suscitando interés entre públicos y performers, la discusión sobre la mejor manera de tocar una obra continuará. En relación al 'deber hacia la obra', algunos se preguntan si el performer realmente tiene la capacidad o el poder para perjudicar o dañar a la obra, o si del mismo modo los performers pueden agradar o desagradar a los antiguos compositores que ya fallecieron. Con respecto a esto, Taruskin afirmó que "nuestras obligaciones son hacia aquellos que están vivos" (1995, p.24).

En la actualidad, los músicos siguen buscando y encontrando fuentes de información en partituras y manuscritos originales, así como nuevas e inéditas obras de compositores famosos. Sin embargo, éstos últimos no parecen haber tenido intención de hacerlas conocer y, de igual modo, nadie puede saber realmente si la intención del compositor es que sus obras se toquen hoy en día, no hay manera de saberlo. Mientras tanto, si creemos que no podemos hacerles justicia, las obras pueden quedar guardadas, y así, en tanto entidades absolutas permanecerán intactas. 
Tanto los teóricos como los músicos encontraron una manera de renovar las obras y redefinir a la performance a partir de 1960s. El movimiento de la performance auténtica comenzó en la práctica de la música antigua como reacción hacia la performance de obras en instrumentos modernos (no originales) y rápidamente se extendió hacia obras del clasicismo y el romanticismo (Thom, 2011). Deberíamos considerar ahora si existe la posibilidad real de poder recrear las performances de épocas pasadas. Hindemith, quien simpatizaba con la idea de interpretar la música del pasado con los medios de producción que le son propios, advirtió también sobre sus limitaciones porque nuestra forma de ser "no es idéntica a la de nuestros antepasados, y por lo tanto su música, aunque la re-creemos con absoluta perfección técnica, nunca tendrá para nosotros exactamente el mismo significado que tenía para ellos" (Hindemith, 1952, pp. 170-171). Taruskin puso a Stravinsky como ejemplo de un compositor que cambió su opinión sobre diversos asuntos interpretativos a lo largo de su carrera. Existen grabaciones de Stravinsky interpretando sus propias obras que dan cuenta que no habría posibilidad de considerar a una única performance como correcta; las mismas presentan diferencias lo suficientemente significativas como para pensar que "el advenimiento de las grabaciones solo ha exacerbado la dificultad de determinar el estado ontológico de las obras musicales." (Taruskin, 1995, p. 14).

Taruskin descree de los movimientos auténticos o históricos de la performance y afirma que responden a valores modernistas que son validados por la academia y el mercado (Taruskin, 1995). Consideramos que, si bien estos movimientos pueden ser oportunistas, trajeron aparejado el surgimiento de un interés renovado hacia un repertorio antiguo, tanto de parte del público como de los performers.

Podría pensarse también -más allá de que estemos o no de acuerdo- que el surgimiento de estos movimientos también tienen que ver con una necesidad que tenemos de renovar la manera en que tocamos la música. Tocar una obra a partir de la composición 'inédita' (un Urtext), sin fraseo y manteniendo el nivel dinámico (sin crescendos y decrescendos, ni produciendo contrastes de intensidad) sería algo parecido a limitarse a 'tocar las notas'. Interpretaciones como estas eran bastante frecuentes en las décadas de 1950-1960, y eran criticadas por ser simples reproducciones de las notas y carecer por completo de musicalidad: "Eran malas interpretaciones, y no cumplían ningún propósito musical útil.” (Kivy, 2001). En ocasiones se conoce que la interpretación literal puede ser errónea, como se documenta en el caso de las Variaciones para piano op. 27 de Anton Webern y sus interpretaciones; mientras que los pianistas seguían al pie de la letra las indicaciones de la partitura, se supo finalmente que aquello era lo opuesto a las intenciones del compositor (Hill, 2002). 
Cuando Claude Debussy tuvo la oportunidad de conocer y escuchar al pianista George Copeland tocando una de sus obras, le dijo que nunca pensó que escucharía su música tan bien tocada como él lo hacía. Copeland de algún modo se ganó así el lugar de intérprete autorizado para las obras de Debussy, aún cuando éste último le manifestó que sin embargo él mismo las sentía de un modo diferente (Taruskin, 1995). Este es un caso posible en el que las intenciones del compositor se satisfacen sin que esto implique que deban ser las mismas que él pensó al momento de crear la obra .

\subsection{La performance musical, una vez más}

La repetibilidad de las obras es una de las principales características de la performance musical (Cone, 1968). Aquel que disfruta del canto de un ruiseñor sabe que se encuentra en presencia de un acto único, irrecuperable. La diferencia entre los objetos naturales y los objetos hechos por el hombre -como las obras de arte- puede ser en principio la intencionalidad artística, y en segundo lugar, para las artes performáticas, la intención de que ese algo sea repetible.

Edward Cone se refirió a las condiciones que la música debe presentar para ser considerada como una obra de arte. Uno de los aspectos relevantes es el marco que la música necesita para separarse y diferenciarse del exterior como ocurre con un cuadro expuesto en una galería; ésto es necesario también para establecer dónde hay que mirar, dónde se enfoca el objeto de atención. En el caso de la performance, es necesario separar el continuo del tiempo cotidiano y el tiempo de la obra, algo que en el continuo temporal de la experiencia da cuenta de que comienza la obra y, para finalizar, que está por terminar (Cone, 1968).

Para Cone, la mayoría de los músicos acordaría en que aunque una performance musical ideal pueda ser concebible, sería difícilmente posible de lograr, y que cada performance real debe ser como mucho una aproximación a ella. No se da el mismo caso en las artes cuyos objetos están claramente delimitados, fijos e inmutables; aunque, en estos casos, la experiencia del que observa puede realizarse varias veces y de diferentes maneras. Las artes temporales en cambio están sujetas a lecturas, interpretaciones y actuaciones, pero sin embargo su esencia "permanece allí, en alguna parte, para ser descubierta y, en la medida de lo posible, expuesta" (Cone, 1968, p. 33).

Mientras que en las obras estáticas el objeto ya se ha presentado (o está presentado), en la música en vivo el performer debe elegir una única performance completa: la obra debe continuar y no puede volver atrás para explicar; por esto es importante que lo haga de la manera más clara posible. Cada interpretación válida, entonces "no representa una aproximación hacia algún ideal, sino una elección: 
¿cuáles de las relaciones implícitas en esta pieza serán enfatizadas, para volverlas explícitas?" (Cone, 1968, p. 34).

Las elecciones para Cone no necesitan ser permanentes; incluso para la mejor performance: ésta podría volverse aburrida debido a la repetición. Quizás por esto la contemplación del ruiseñor es un caso particular, porque sabemos que es único. Según el autor:

\begin{abstract}
...a medida que pasa el tiempo, vemos las composiciones de nuevas maneras. Lo que ahora es obvio puede ser olvidado y necesita ser señalado nuevamente; lo que ahora no está claro puede convertirse en el cliché del mañana. La interpretación debe tener en cuenta dichos cambios y cambiar con ellos. (Cone, 1968, pp. 35-36)
\end{abstract}

Entonces en una presentación de una obra, la performance es una instancia en la que no podemos saber con seguridad cómo será llevada a cabo por el artista. Cone dice que aunque sepamos de memoria una pieza, el performer podría engañarnos y sorprendernos con algún cambio en la ejecución. El músico tiene la habilidad de poder, a través de una actuación convincente, absorber al oyente en el flujo de la música aunque éste conozca la obra, y hacerlo disfrutarla como si fuera la primera vez. Ante la imposibilidad de la existencia de una performance ideal, el autor no se lamenta sino que lo considera una ventaja: "Es mejor, entonces, que no pueda existir una interpretación ideal. Porque si hubiera existido, podríamos haber dejado de escuchar a Mozart y Beethoven hace mucho tiempo. Es la renovada vitalidad de cada performance lo que los mantiene vivos." (Cone, 1968, p. 56).

\title{
2.5 Síntesis
}

En una performance musical, el performer es el encargado darle a la obra musical una materialidad física, realizada principalmente por la producción sonora de la partitura. Las investigaciones acerca de la performance musical se han ocupado del análisis de grabaciones de sonido y movimiento, abordando cuestiones de timing y expresión en valores medibles que son comparados con el contenido normativo de la partitura, o entre diferentes performances de una misma obra.

La definición de la música como arte performático permite realizar otro tipo de consideraciones acerca de la performance. Si bien deben cumplirse ciertas condiciones de adecuación con respecto a la partitura, la performance como un caso es una presentación única ante un público, en donde la obra se presenta con sus cualidades de sonido y movimiento en el tiempo. Además, permite cambiar el foco desde el deber con la obra hacia el 'deber' de presentar una actuación que revele nuevos aspectos de la obra con respecto a expectativas similares por parte del 
público. La obra musical, sin embargo sigue siendo aquí una entidad independiente cuyas propiedades no son posibles de ser modificadas o igualadas.

Al correr el eje de discusión en la obra como entidad inmanente hacia la intencionalidad humana de la performance, aparece la figura del compositor reclamando el lugar de su intencionalidad humana en la performance de la obra. Asimismo, las posturas historicistas postulan la intencionalidad compositiva en el contexto de la práctica, rescatando el modo en que las obras eran performadas originalmente. De este modo, puesta la intencionalidad en relieve, el performer se encuentra en un contexto social complejo, donde la fidelidad de la obra es reclamada desde diferentes posiciones. En el contexto actual, una gran parte del repertorio que se presenta en las salas de concierto pertenece a un pasado lejano, mientras que la performance debe ser constantemente resignificada socialmente por el conjunto de relaciones que constituye.

Pensar la música desde la performance permite cambiar la perspectiva centrada en la obra y la reproducción de su significado hacia la performance, donde existe un significado que es creado en ese mismo acto. En este sentido, la música como performance es el comienzo para hacer sentido de las partituras, aunque esto no sólo debería ser una cuestión de sonido: las grabaciones tienen la posibilidad de ser repetidas de manera exacta (como una película), mientras que cada nueva performance se presenta como una experiencia única.

La interpretación musical es uno de los problemas centrales en la discusión acerca de las adecuaciones de las performances con respecto a la partitura. El texto musical, sin embargo, no puede contener toda la información necesaria para determinar una performance $y$, en relación a la obra, no es más que una representación aproximada. En su lugar, el texto contiene lo repetible.

La repetibilidad de la obra define a la performance musical no por su repetición exacta (su reproducción), sino por la intencionalidad humana de que eso sea repetible. Hoy podríamos grabar la mejor performance de una obra y repetirla, sin embargo existe algo más para valorar a la performance, algo que se podría caracterizar como el compromiso del performer de estar ahí para realizar su performance para el público que asistió. Porque la obra, no su partitura, será presentada en el mismo momento en que la performance -o la obra también, dependiendo como la concibamos- es creada. Sin embargo, sabemos también que la obra ya ha sido creada y que ninguna performance la cambiará. 


\title{
CAPÍTULO 3
}

\author{
Narración y Música. Parte 1 \\ Analogías entre música y teoría literaria
}

Los abordajes de la narrativa musical son aquellos que discuten las posibles analogías entre los aspectos que son considerados como constitutivos de la narración y la música. Al plantear situaciones comunes, estos parten desde preguntas como ¿es la música narrativa?, ¿la música cuenta una historia?, entre otras. Pero como con toda analogía, es imposible establecer correspondencias absolutas, por lo que surgen nuevos interrogantes.

Algunos autores se han tomado el trabajo de revisar y hacer un seguimiento de la discusión existente sobre música y narrativa, una evidencia de que el tema se ha instalado en el campo de la investigación en música. La tarea de dichos autores implica dejar -al menos por un momento- las inquietudes personales a un lado e intentar explicar cuáles son las diferentes corrientes y como se vinculan/separan, qué autores tienen puntos en común, así como también cuáles entran en discusión con otros, etc.

Este capítulo no profundizará demasiado en ninguna de las discusiones, limitándose a una breve exposición. Serán abordados los aspectos más importantes de aquellas que presenten aspectos relevantes para el presente estudio, y nos permitan también avanzar con el desarrollo del marco teórico en el siguiente capítulo, donde presentaremos algunos enfoques particulares que estamos interesados en indagar. ${ }^{23}$ De una manera similar, no nos detendremos en el repertorio musical programático o referencial, en la así llamada música descriptiva o narrativa. ${ }^{24}$ En cambio, nos enfocaremos principalmente en la música instrumental.

\subsection{Narrativa y Música a finales del siglo XX}

Varios autores señalan a Jean-Jacques Nattiez como el iniciador del debate entre música y narrativa en su artículo del año 1990, Can One Speak of Narrativity in

\footnotetext{
${ }^{23}$ Algunos abordajes en profundidad acerca de las relaciones entre música y narrativa pueden encontrarse en Abbate (1991), Almén (2008), Klein (2013), Maus (1988, 1991, 2005), Nattiez (1990, 2013), Shifres (2007), y Tarasti (1991).

${ }^{24}$ Son aquellas composiciones musicales que claramente poseen una intención narrativa desde una concepción estética.
} 
Music?, un escrito que estaba motivado por el retorno de las ideas sobre narratividad musical en el pensamiento de la musicología. Estas ideas parten de una intuición de sentido común: que el compositor nos habla a través de la obra, lo que dio el puntapié inicial para que la relación entre la música y el lenguaje se estableciera en el centro del debate. Para Nattiez (1990) esta relación es sólo una metáfora que se utiliza para dar cuenta de la especificidad de la música como un despliegue temporal. Podemos considerar que la música tiene cualidades sintácticas que nos permiten entenderla como un discurso, pero si el compositor nos está narrando una historia, eso es algo a lo que no podemos acceder debido a las limitaciones de la música como lenguaje. Dada esta imposibilidad, la historia es algo que quedará entonces en la intención del autor o en una estrategia del oyente que escucha la obra.

Toda relación que se plantea entre narrativa y música parte de algún tipo de definición -ya sea general o específica- de narración, la cual sirve como fuente para el establecimiento de relaciones análogas. Es por eso que las diferentes conclusiones a las que se arriba dependen en este sentido de la fuente que se toma para tal caso. Nattiez toma la definición de relato de Chatman (1978) -la cual realiza una distinción entre historia y discurso- argumentando que en la música las conexiones se sitúan en el nivel del discurso más que en el de la historia: de este modo, para el autor no hay manera de conocer la historia.

Por otro lado, Nattiez se apoya en el argumento de Abbate (1991), quien afirma que la música no puede dar cuenta de una historia porque no posee un tiempo verbal pretérito -como ocurre en el lenguaje- que pueda referir a que la historia haya ocurrido en el pasado. Debido a que la música no tiene la capacidad de significar del mismo modo en que lo hace el lenguaje, tampoco podría mentir o inventar una historia. Es por esto que el autor finalmente toma las palabras de Adorno para decir que la música no es más que una narrativa que no se relaciona con nada (Nattiez, 1990) ${ }^{25}$.

El panorama de la narrativa musical, lejos de poseer una posición unificada, presenta un desacuerdo general acerca de su naturaleza, propiedades y rango de aplicación. Almén (2008) se ha encargado de reunir posiciones a favor y en contra, haciendo un seguimiento de cómo los investigadores toman las metodologías de análisis y el vocabulario de los enfoques literarios sobre la narrativa para considerar una posible analogía con la música. Algunos de los temas en discusión son: (i) la ausencia de referencialidad en la música, (ii) la relación sujeto-predicado, (iii) el narrador y (iv) el tiempo verbal pretérito. Siguiendo a Almén, resulta inevitable que al tomar los principios de la teoría narrativa la música quede en una posición parasitaria, de modo que las analogías que puedan establecerse siempre estarán por debajo de

\footnotetext{
${ }^{25}$ Nattiez hace referencia a esta frase de Adorno sobre la música de Mahler en Eine
} musikalische Physiognomik (1971). 
las expectativas y resultarán en intentos frustrados. Autores como Almén (2008) y Maus (2005) sugieren evitar este tipo de comparaciones directas y buscar en su lugar, relaciones análogas más modestas.

En la búsqueda de una definición más amplia de la narrativa, encontramos que muchos autores coinciden en que la narración está presente en la vida cotidiana: estamos rodeados de historias y somos narradores en nuestro día a día. La narración entonces puede dar cuenta de una actividad humana y comunicacional por fuera de la literatura, algo a lo que nos referiremos más adelante. Al respecto, se considera que la narrativa permite estructurar aspectos de la vida y la experiencia, debido a que construímos relaciones narrativas que aplicamos al re-construir nuestra propia vida como historias, organizando los eventos y sus relaciones a través del tiempo (Fludernik, 2009).

Uno de los aspectos centrales de la narración es que este tipo de estructura literaria es caracterizada frecuentemente en relación a su "naturaleza" temporal. A diferencia de otro tipo de discursos -como el descriptivo, el expositivo, el argumentativo y el instruccional- la narración presenta un tratamiento del cual se destaca su organización temporal, utilizada para expresiones sobre ocurrencias y cambios en el tiempo. Según Werlich (1968) -quien propuso la diferenciación entre las cinco estructuras antes mencionadas- estas clases textuales no están dadas de manera objetiva sino que se constituyen en la interacción comunicativa del saber cotidiano de aquellos que participan en la comunicación.

\subsection{El abordaje de la música desde la teoría narrativa literaria}

Un texto narrativo presenta una serie de elementos narrativos. Uno de ellos es la sucesión temporal de eventos, cuya secuencia más simple es la que introduce (i) un problema o complicación con respecto a una situación inicial, y (ii) una resolución que da lugar al final (Adam, 1992). Un texto narrativo se refiere a acciones de personas en donde un hablante -suscitando el interés- explicará sucesos o acciones donde la complicación y la resolución constituyen el centro. Cada suceso tiene lugar en un marco determinado dentro del cual pueden ocurrir varios sucesos, donde marco y suceso conforman un episodio, y que a su vez una serie de episodios definen la trama (Contursi y Ferro, 2000). De esta manera, los textos narrativos pueden ser analizados como conformando una estructura jerárquica o superestructura.

El abordaje estructuralista para explicar la narrativa musical es uno de los más frecuentes y establece correspondencias entre el modo en que la narrativa literaria y la música se organizan temporalmente. Por un lado, tenemos las estructuras o tramas arquetípicas de la narración y su correspondencia con los esquemas de la forma 
musical; por el otro, la capacidad de la música tonal para producir un discurso de tensiones y distensiones (elementos opuestos) y su posterior resolución.

\subsubsection{Estructuras narrativas}

El estudio del discurso narrativo en la literatura dió origen a una sub-disciplina, la Narratología, cuyos principales autores (Genette, Prince, Chatman, Standzel, Lanser

y Fludernik) abordaron las relaciones entre historia y discurso, ${ }^{26}$ que es el objeto del análisis que se realiza sobre los textos literarios.

Chatman $(1978,1981)$ postuló la existencia de una estructura profunda que contiene dos estructuras independientes del tiempo: una, es la secuencia de eventos de la trama, llamada el "tiempo de la historia"; y la otra es la presentación de dichos eventos en el texto, o el "tiempo del discurso". La tensión entre los dos tiempos -(i) el tiempo lineal de la historia; y (ii) el orden en el que los eventos son presentados en el discurso- es una característica principal de los textos narrativos que abordan los análisis narratológicos.

El análisis de los textos musicales (las partituras) se ha visto influenciado por la Narratología. El estudio de la estructura de la trama o la sintaxis narrativa -una tradición del formalismo ruso, continuada por los estructuralistas- identifica los elementos recurrentes dentro de las tramas y establece sus reglas de combinación. Las estructuras que los teóricos de la música han encontrado en la organización de cierto conjunto de obras narrativas los ha llevado a la articulación entre ambas. Propp analizó e identificó treinta y una funciones morfológicas en los cuentos populares, sucesiones abstractas que fueron vistas como análogas al estudio de las formas o arquetipos musicales (como la forma sonata) (Maus, 1991). Para Newcomb (1987), mucha de la música clásica y romántica puede ser entendida bajo la analogía de las tramas paradigmáticas o tipos de trama, especialmente en la música sin texto.

Abbate (1991) destaca otros ejemplos de aproximaciones a las estructuras paradigmáticas de la música: (i) el Formenlehre tradicional del siglo XIX (promulgado por A. B. Marx) analiza las obras individuales como recomposiciones de tipos paradigmáticos formales (sonata, rondo, etc.); y (ii) el análisis de Schenker, que entiende el texto musical en tres niveles o bases (profunda, media y superficial), de las que se privilegia la Urlinie de la base profunda como una estructura básica común a toda la música canónica.

Dada la capacidad del discurso musical para crear tensiones y distensiones, la música tonal es para algunos autores el modo de explicar el estatus narrativo de la

${ }^{26}$ En algunas traducciones al español, también es enunciado como historia y relato. 
música. Al crear un discurso en su propio lenguaje, se entiende que la música tonal puede entonces narrarse a sí misma (McClary, 2000).

Para Klein (2013), en cambio, la narración requiere de actos de intención, por lo cual la tonalidad y la forma no hacen el trabajo de crear una trama narrativa por sí mismas, lo que nos llevaría a considerar el problema del narrador en la música: "la tonalidad no es un prerrequisito para representar un narrador musical" (p.14). La figura y función del narrador en la música serán tratadas más adelante, pero se vinculan con la atribución de la narración a una persona, un agente, una voz real o virtual. La tonalidad allanó el camino a muchos teóricos que insistieron con la relación entre narrativa y música, confiando a la organización semántica del discurso tonal la solución a su imposibilidad de asemejarse al lenguaje verbal.

McClary (2000) considera que la funcionalidad de la tonalidad permite el desarrollo de la narrativa musical en modos que las técnicas post-tonales no pueden hacerlo. Klein (2013) sostiene que la narrativa y la música son frecuentemente asociadas bajo la consideración de características particulares de la música tonal, sin tener en cuenta a los repertorios de obras posteriores, y de esta manera se enmascara una ideología (la tonalidad) con otra (la narrativa), o dicho de otra manera, la narrativa podría ser utilizada como excusa para una validación de la música tonal por sobre las otras músicas.

\subsubsection{La narrativización de la partitura}

Hasta ahora hemos visto que una parte importante de la narrativa musical se apoya en la capacidad del compositor para generar una narrativa en la organización temporal de la obra. La teoría narrativa nos brinda algunas metáforas interesantes para pensar acerca de la música, las cuales podemos tomar por separado o intentar reunirlas en un discurso narrativo. Si bien las metáforas que se proponen para su relación con la música se apoyan en la tonalidad como un significante, y su discurso nos permitiría compararlo con un discurso narrativo, no podríamos acceder de esta manera a la historia, y sin historia no habría narrativa, esto es, "algo" que narrar (Klein, 2013).

Al basarse en los textos musicales (partituras), los analistas han encontrado maneras de otorgar significado narrativo a las obras en el modo en que éstas organizan sus eventos musicales en estructuras, patrones armónicos, motivos, entre otros. Sin embargo, resultan en mediaciones de lo que el autor 'quiso contar o narrar' $\mathrm{y}$, en cierto modo, terminan narrativizando la obra: creando un medio a través del lenguaje verbal en el que ellos (los analistas) nos narran la obra. Fludernik (2003) 
considera que la narratividad no es una cualidad que se adhiere a un texto, sino un atributo impuesto por el lector que interpreta al texto como narrativo, narrativizándolo.

Los análisis de las obras, sostiene Abbate, son interpretaciones de la música expresadas de manera verbal: "son performances y sólo pueden ser más o menos convincentes" (1991, p. xi). Para tales fines, sería más adecuado decir que la música se presta a su descripción narrativa, pero no constituye necesariamente una narrativa inmanente. Estos análisis de los siglos XIX y XX que describen a las obras musicales como narrativas se basan en la idea de narración como cualquier secuencia de eventos. De esta manera, los gestos musicales se conciben como signos de acciones humanas -que pueden ser actos físicos o estados emocionales- al asumir que la música es narrativa porque imita al drama. Así, se produce una analogía con los elementos lineales de la música en el tiempo: (i) sus expectaciones generadas y nuestras comparaciones con los paradigmas conocidos; y (ii) las tensiones y resoluciones que se mueven como eventos sónicos hacia un cierre. Entonces, como los eventos en una trama dramática, los elementos de la música son percibidos como una recreación ${ }^{27}$ de manera análoga a la narrativa de una obra teatral 0 al cine (Abatte, 1991).

\subsubsection{Agencia}

Aunque podemos narrativizar casi cualquier objeto que no sea una narración literaria, e incluso a una narrativa existente, se considera que el objeto tiene que tener ciertas cualidades que "inviten" al observador a considerarlo como tal. Es por esto que algunos autores consideran la relación entre música y narrativa otorgándole al oyente una intencionalidad para estructurar o adoptar comportamientos narrativos ante la música (Maus, 2005; Meelberg, 2006; Nattiez, 1973; Tarasti, 1994).

Dado que la música instrumental presenta una serie de eventos, algunos autores dicen que podemos entenderlos como acciones o comportamientos que se atribuyen a acciones humanas, e integrarlas a una trama; estas acciones humanas pueden ser atribuídas a un agente de la acción narrada (por ejemplo, un personaje). Se considera así que los oyentes tienen la capacidad de interpretar eventos musicales de manera antropomórfica, y escucharlos como si fueran una historia, y de este modo encontrar acciones, pensamientos y personajes en la música (Maus, 1991). Entre los autores que consideran posible una analogía entre música y teatro (Maus, 1988; Hatten, 1991; Klein, 2004), Maus sostiene que la música es como el teatro pero sin personajes, porque presenta una serie de acciones que son performadas (actuadas) al mismo tiempo que la audiencia las percibe, sin que exista la necesidad de un narrador,

${ }^{27}$ En el original, enactment. 
y que ésto da forma a una trama que sostiene a las acciones juntas en una estructura unificada (Maus, 1988).

\section{3 ¿Quién narra la historia?}

Narrar una historia puede significar la presencia de quien está contando la historia y un receptor a quien le es contada, comúnmente denominados narrador y narratario. Dentro de la tradición estructuralista, Gerard Genette propuso un modelo triádico para el análisis de la narración, compuesto de: (i) la historia (que integra el conjunto de los acontecimientos que se cuentan); (ii) el relato (discurso, oral o escrito, que los cuenta) y la narración (el acto real o ficticio que produce ese discurso: el hecho de contar en sí mismo) (Genette, 1983). Mientras que los dos últimos se pueden considerar como el "discurso narrativo", la historia se encuentra en otro nivel (del modo antes mencionado, entre historia y discurso). Esta distinción rescata la actividad basada en la acción de contar historias, un acto narrativo que, aunque pueda ser considerado aparte del texto (en el caso que exista) plantea una relación entre texto y acto a la vez que permite incluir prácticas narrativas sin la presencia de textos.

Según Fludernik, el narrador es quien cuenta la historia, por lo tanto, "la narrativa es la historia que el narrador cuenta" (2009, p.4). A pesar de esta simple definición, la figura del narrador es más compleja: mientras que para un relato oral corresponderíamos al narrador con la persona que enuncia la narración, en las narraciones literarias el narrador puede presentarse de diferentes maneras, o no presentarse de manera explícita, siendo sugerido por un recurso narrativo o inferido por el lector. De todos modos, al decir que el narrador es 'quien cuenta la historia' no deberíamos confundirlo con el autor del texto.

Cuando se discute el rol del narrador en la música se argumenta que no puede cumplir con las siguientes funciones: (i) situar los eventos relatados en el pasado, como algo que ya ocurrió; (ii) organizar el argumento o trama de una manera coherente; y (iii) proveer un mediador entre la historia y el lector. Con respecto a la primera, puede argumentarse que algunas narrativas literarias a menudo hacen un uso no gramatical de los tiempos verbales y de los llamados deícticos, y que el uso alterado de los tiempos verbales, aunque diferente de la comunicación fáctica, crea, sin embargo, su propia separación coherente del pasado y el presente sin referencia a un narrador. Con respecto a los puntos 2 y 3 , se argumenta que la tarea de hacer conexiones entre eventos en una secuencia temporal no depende esencialmente de la presencia de un narrador, y que el lector puede desempeñar el papel principal en este sentido (Almén, 2008). 
Algunos de estos argumentos que nombra Almén muestran una vez más que las relaciones análogas entre narrativa y música dependen en cierta medida de la definición y las categorías de análisis de la teoría narrativa en la que se basan. De esta manera, el argumento para invalidar una narrativa musical, como es en éste caso el de la posibilidad de un narrador, o para validarla, no implica que necesariamente debamos abandonar la idea de una narrativa en la música. Del mismo modo, puede argumentarse que existen maneras de narrar que no requieren de la utilización del lenguaje verbal como medio, como por ejemplo la que implica la actuación de un mimo o la que sucede en el arte audiovisual, sobre todo las películas mudas (donde no aparecen intertítulos). ${ }^{28}$

El autor de una narración literaria puede decidir incluir o no un narrador, que puede estar representado por un personaje o estar ausente:

El "narrador", cuando aparece, es una entidad demostrable y reconocible inherente a la narración misma. Toda narración, incluso las que son totalmente "mostradas" o no mediatizadas, tiene en última instancia un autor, el que la ideó. Pero "narrador" no debiera usarse en este sentido. Solo debiera significar el alguien, persona o presencia, que realmente cuenta la historia a un público, sin que importe que apenas se evoque su voz o el oído atento del público. Una narración que no nos sugiere esta presencia, que ha tratado evidentemente de eludirla, puede con razón ser llamada "no narrada" o "innarrada". (La aparente paradoja es solo terminológica, viene a resumir "una narración que no está contada explícitamente" o "que evita dar la impresión de ser contada".) Por tanto, no hay ninguna razón para proponer una tercera categoría narrativa (como "dramática" u "objetiva", o algo por el estilo) puesto que esa sería esencialmente una "narracion no narrada". (Chatman, 1978, pp. 33-34)

Como podemos apreciar, el narrador mantiene cierta relevancia mientras la narración es producida en acto por un sujeto que cuenta la historia, mientras que cuando se trata de un texto como el literario, ésta figura puede ser evadida o reemplazada por algún tipo de estrategia discursiva o procedimiento literario. En otras palabras, en los textos literarios el narrador depende de cierta decisión del autor, constituyendo una creación del mismo, en la forma que lo considere mejor. De todos modos, es importante destacar aquí la importancia de una persona que cuenta la historia para la definición del narrador.

Otro tipo o modo de narrar es el que se entiende como el reconocimiento de un punto de vista, denominado focalización: éste designa a una relación entre la percepción y lo que se percibe. Del mismo modo que una narración puede contar con uno o más narradores, el focalizador puede variar a lo largo de una narración, aunque

${ }^{28}$ Los intertítulos son recursos de la cinematografía, generalmente utilizados en películas sin diálogos. La función que cumplen es la introducir imágenes con contenido verbal en párrafos que narran o comentan las acciones, así como también diálogos de los personajes que permiten entender lo que ocurre. 
no se corresponde necesariamente con el narrador, debido a que éste último puede dar cuenta de cómo los personajes han focalizado, o percibido determinadas acciones (Bal, 1997).

El acto de narrar supone además considerar a una persona o destinatario que recibe la narración. Se dice entonces que la eficacia de la narración no depende únicamente de la figura construida del narrador, sino que se entiende que el lector cumple también una función narrativa que surge de aceptar los pactos que el narrador propone (Contursi y Ferro, 2000). En el caso del narrador, podríamos decir que el lector puede construirlo a partir de una interpretación. De este modo, existen narradores o lectores implícitos o modélicos: el primero es el que puede inferirse desde la recepción, mientras que el segundo es el que el narrador imagina o induce a partir del modo en el que cuenta la historia.

Para Tarasti, el sujeto intencional que sería equivalente al narrador en la música surge de la cooperación o interacción entre el compositor, el intérprete y el oyente (Tarasti, 1994). Para Meelberg (2006), sin embargo, el compositor y el intérprete no igualan automáticamente la función del narrador:

\begin{abstract}
Un narrador musical, siempre que sea imperceptible, no puede señalarse claramente en la música en sí o en una situación de ejecución, y en su lugar se postula en el texto musical como un todo, o en el texto incrustado en el caso de un narrador incorporado, tan pronto como este texto se considere narrativo. Un narrador perceptible, por otro lado, puede señalarse en la música, lo cual tiene sentido, porque si esto no fuera posible, entonces el narrador no sería perceptible. (p.48)
\end{abstract}

A pesar de no considerar que la música pueda por sí misma dar cuenta de un narrador, existe cierto consenso en que los "cambios" en el discurso musical tienen el potencial de dar voz a una narración (Abbate 1991, Hatten 1991, Klein 2004, Kramer 1990, Webster 1991). Micznik (2001) considera que la voz del narrador/compositor se siente con igual fuerza en ciertas obras de Beethoven y Mahler, ya que "crean la ilusión de hablar desde el punto de vista de su propio compositor, a través de los mundos elegidos para ser presentados y a través del particular medio de presentación" (p.247). En The Composer's Voice, Cone (1974) entiende a la voz como una presencia o inteligencia resonante, una inteligencia en el acto de pensar a través de la obra musical. En breve, la voz es la de un autor virtual, asociando la idea de voz a la de una mente creativa -la que suponemos que ha creado la obra- como un todo, idea sobre la que Abatte (1991) manifestó su rechazo por "controladora y monológica", al mismo tiempo que le otorga demasiado crédito a la figura del compositor. Newcomb (1984) afirmó que "la concepción de la música como la novela del compositor, como un curso de ideas psicológicamente verdadero, fue y es una vía importante para la comprensión 
de mucha música del siglo XIX" (p. 234), dando a entender que puede considerarse a la música como si fuera un debate de los movimientos opuestos que se suceden en una obra, a la manera de "tramas arquetípicas" que sustentan la narración del compositor.

\subsection{Síntesis}

La consideración acerca de la música como narrativa parte de una experiencia o intuición de que la música está contando algo, aunque no sepamos a ciencia cierta qué es. Estas consideraciones pueden ser defendidas sobre la base de la presencia de la narración en la vida cotidiana. La búsqueda de relaciones análogas en la literatura existente acerca de la relación entre música y narrativa propone en estos casos la aplicación de definiciones de la teoría narrativa literaria, la cual posee sus propias categorías y temas pertenecientes al análisis de los textos literarios.

La dimensión temporal de la música es la base de toda analogía, aunque se encuentra con la problemática de la imposibilidad de comportarse como un lenguaje referencial y semánticamente equivalente al discurso verbal. De ésta manera, varios autores rechazan la idea de que la narrativa en música pueda sostenerse como un asunto entre historia y relato.

La música tonal resulta análoga en aspectos estructurales y discursivos en sus propios términos, aunque permanece encerrada en las categorías de su análisis musical. Además, queda en evidencia que su aplicación en otras maneras de organizar su lenguaje no puede realizarse del mismo modo.

La perspectiva del análisis de los textos musicales evidencia la necesidad de un enfoque que contemple al acto narrativo y al oyente receptor ( $y$ sus implicancias en la comunicación que serán abordadas en el siguiente capítulo). Al plantear la idea de un narrador que "cuenta la historia" nos encontramos con un enfoque hacia el compositor (organizador del discurso) y al analista/oyente que realizan narrativizaciones de la música (interpretaciones narrativas de la obra), y pocas referencias hacia el intérprete/performer.

Es por esto que en el siguiente capítulo profundizaremos en la narración como acto, desde la perspectiva del músico performer para la consideración de una analogía entre narración y música que lo ubique como el narrador musical. 


\section{CAPÍTULO 4}

Narración y Música. Parte 2

Analogías entre interpretación musical y acto narrativo

Como hemos visto anteriormente, los enfoques de la narrativa musical se han ocupado principalmente del abordaje de los textos musicales $\mathrm{y}$, al hacerlo, aplicaron las categorías de los textos narrativos literarios. En la búsqueda de un marco que permita pensar en la narración como una acción e intencionalidad humana, en este capítulo presentamos enfoques que suponen un giro en la consideración para la relación entre narrativa y música; estos se ocupan de la performance musical como narración y tienen una consideración especial hacia el performer.

A continuación, se introducen marcos de la psicología del desarrollo, la psicología social y la cognición social que abordan a la narración como un acto entre un narrador y un narratario. Estos enfoques ponen en relieve el rol del lector como participante en la narración y los modos de comunicación interpersonal que dan sentido a las narrativas. De este modo, la intencionalidad humana permite repensar el lugar del texto en la narrativa literaria y entender al significado de los mismos dentro de un intercambio de posibilidades humanas.

Finalizamos este capítulo haciendo consideraciones sobre los enfoques presentados, derivando temáticas de interés para nuestro estudio de la performance musical.

\subsection{El performer como narrador}

La analogía que considera al performer involucrado en una narración musical fue sugerida por Rink (1994), cuando enunció que "es el performer quien, como un 'cuentacuentos', determina el contenido 'narrativo' esencial de la música al seguir las indicaciones de la partitura como una 'trama' y, como en la puesta en acto de cualquier 'trama arquetípica', dando forma de manera expresivamente apropiada a la historia en desarrollo" (p.112). ${ }^{29}$ Años más tarde, la idea era presentada por el mismo Rink a

\footnotetext{
${ }^{29}$ La traducción es nuestra. En el original, Rink utiliza el término inglés 'story-teller' que puede ser traducido como narrador, cuentista o cuentacuentos, es el que cuenta una historia.
} 
través de la metáfora del performer como narrador $r^{30}$ en un escrito donde desarrollaba sus ideas acerca de la performance histórica, proponiendo que los intérpretes actuales de la música del siglo XIX "pueden dar vida a la partitura como un narrador del mensaje expresivo inherente a ella" (Rink, 1999, p. 217). ${ }^{31}$

Al profundizar en la descripción del performer como narrador, Rink lo caracteriza en la realización de tres acciones: (i) el estudio de la partitura, para revelar un mensaje o significado particular; (ii) la construcción de un marco temporal para su proyección y (iii) una traducción en sonido. El autor dice que mientras el performer está tocando se establece un diálogo continuo entre la arquitectura integral y el "aquí y ahora" para el despliegue de eventos musicales sucesivos, en un enunciado coherente. Destacamos aquí algunos aspectos que consideramos relevantes en su propuesta: (i) la traducción de la notación al sonido que podemos entender como la producción de la narración; (ii) que este tipo de lectura varía "de performer a performer"; (iii) el medio particular donde se produce la expresión del intérprete, este caso, el sonido; y (iv) la mención acerca de un "plano diferente" a donde puede ser transportado el oyente (Rink, 1999).

\subsection{La performance como focalización}

En el contexto de la música instrumental contemporánea, Meelberg (2006) realizó un estudio con análisis de partituras y grabaciones con una orientación narrativa; en el escrito, se enfatiza que las obras musicales solamente llegan a existir cuando se presentan como sonido. El autor entonces considera que el compositor no es la única persona necesaria para la creación de la música, y que la partitura (el guión escrito) sirve para asegurar la continuidad de la existencia de una obra, pero también deja abiertas varias opciones: "con la ayuda de este guión, el o los performer/s pueden dar una interpretación de la pieza musical que el compositor ha concebido" (p. 67). ${ }^{32}$

Al centrarse en la obra como entidad sonora, las analogías narrativas son aplicadas en relación a la performance, más precisamente a la relación entre la partitura y la performance como producción sonora. Meelberg (2006) dice que la composición está escrita en la partitura como los trazos o contornos de los dibujos de un libro para colorear, mientras que las propiedades sonoras de la performance "colorean" lo que ya ha sido escrito por el compositor. ${ }^{33}$

\footnotetext{
${ }^{30}$ En el original inglés: performer as narrator.

${ }^{31}$ La traducción es nuestra.

32 La traducción es nuestra.

33 Meelberg toma esta idea de Benson (2003), quien cita palabras de la compositora de jazz Carla Bley, para decir que la interpretación es análoga a la coloración del libro.
} 
Cuando la narración literaria es abordada desde las personas que realizan acciones dentro de la historia o la narran, éstas son distinguidas en el análisis a partir de figuras como el narrador, el focalizador y el actor. El narrador es definido como un agente que relata a través de los signos (el texto), y puede ser una persona que relata la historia desde afuera (narrador de tercera persona) o puede identificarse con un actor o personaje que la relata desde adentro (narrador de primera persona). El narrador habla a través de los signos que emite, pero no puede identificarse con el escritor ya que éste último sólo recurre al primero como un "vocero ficticio". La focalización, en cambio, se vincula con el modo en que los eventos son presentados en la historia, pero se caracteriza por hacerlo desde un punto particular esto es, da cuenta de una "visión" desde de la cual son presentados; por lo tanto implica el punto desde donde los eventos son percibidos. Entonces, un mismo texto puede ser relatado por un agente externo o por cualquiera de los personajes, entendiéndose que su relato implica una visión personal desde donde es percibida la historia. El focalizador es el sujeto de la focalización, y dependiendo de la narración su función podría superponerse con la del actor y la del narrador. En la narrativa literaria, se realizan todas estas consideraciones acerca de las personas que participan en una narración y se las distingue para realizar un análisis en estratos, y descubrir así cómo se organiza la narración (Bal, 1997).

Para Meelberg, el compositor o el performer musical no igualan automáticamente la función del narrador. El performer no se limita únicamente a emitir los signos, sino que está más involucrado en "colorear" la partitura con su propia subjetividad, entendiéndose mejor su función a través del focalizador. Debido a que cada performance es diferente, el autor considera que cada performance puede ser una nueva narrativa a partir de una nueva focalización.

En una narración literaria, el focalizador puede ser uno de los personajes de la historia quien emite los signos del texto desde su visión; el lector puede advertirlo porque la información del focalizador y su lugar en la obra ya están implícitos o escritos en el texto. En la música, sin embargo, el texto no produce por sí solo la obra, entonces la focalización sucede cuando la obra finalmente se instancia en sonido. Entonces, mientras que en la literatura la focalización o las focalizaciones son idénticas para cada lectura de la narración, "en música la focalización puede, y casi siempre lo hará, cambiar en cada performance. Ninguna performance es la misma, y entonces, pueden existir diferentes interpretaciones, y por lo tanto diferentes focalizaciones, de la misma obra musical." (Meelberg, 2002, p. 69). ${ }^{34}$

\footnotetext{
${ }^{34}$ La traducción es nuestra.
} 


\subsection{Voz y presencia en la performance}

La voz en la narrativa es una categoría de análisis que recurre a un fenómeno que no ocurre en el texto (una voz que suena), pero que se basa en la imagen del discurso hablado o pronunciado para entender cómo la narración puede ser entendida en términos de alguien que cuenta la historia. La voz narrativa se dilucida entonces con la pregunta ¿quién habla?, y se corresponde con el modo en que el narrador se sitúa cara a cara con la narrativa: desde afuera (heterodiegético) o desde adentro (homodiegético) (Genette, 1972). Davies (1994) enfatiza el carácter expresivo de la música como una apariencia humana, y dice que podemos entender las acciones en una estructura narrativa cuando las percibimos de manera unificada, moldeadas por la voluntad de un agente autónomo:

...el sonido de la música es como la apariencia de una persona con respecto a su carácter expresivo. Otra posibilidad es esta: la identidad de una persona persiste en el tiempo, en parte porque sus acciones están unificadas, y esas acciones se cohesionan porque (a menudo) son moldeadas por la voluntad del agente autónomo con miras a su consistencia, a lo que podría llamarse su estructura narrativa. (Davies, 1994, pp. 367-368). ${ }^{35}$

Abbate explora la idea de voz como una metáfora o idea presente en la producción estética del siglo XIX que surge a partir de la voz cantada. En su pensamiento, la idea de voz no es tomada en un sentido literal para referirse a las obras vocales, sino que además se vincula con un modo particular de entender a la música instrumental. Tomando las ideas de Cone (1974) como punto de partida, la voz para Abbate (1991) no sugiere la figura del compositor como una autoridad monológica, y en cambio surge desde la performance como "un recordatorio necesario de que la música es escrita por el compositor, pero hecha y proporcionada en realidad fenoménica por los performers" (p. x). ${ }^{36}$

El interés principal de Abatte es la aplicación de sus ideas en la música de Ópera, pero -aún conservando su propósito- las desarrolla en el contexto de la discusión narrativa en un sentido más abarcador y amplio de la música, que se extiende hacia otros tipos de obra (obras orquestales, instrumentales, etc.). Mientras que en una Ópera las voces pueden ser concretas (las de los cantantes), formar parte de descripciones analíticas y técnicas (las líneas contrapuntísticas individuales de la polifonía), o tener un tratamiento compositivo como un elemento más de la obra (un

\footnotetext{
${ }^{35}$ La traducción es nuestra.

${ }^{36}$ La traducción es nuestra.
} 
objeto de voz); la autora dice que los gestos aislados en la música ${ }^{37}$, aunque sean o no vocales pueden ser entendidos como enunciados de personas.

Si bien el análisis literario de la narración proporciona términos como tramas y secuencias de acciones que nos permiten pensar en una narrativa musical, Abbate (1991) sostiene que la voz no puede ser suprimida de ésta especulación: "Centrarse en el sujeto, el narrador y la voz narrativa, y afirmar que la narrativa siempre involucra a un narrador y un oyente, no meramente una historia, significa adoptar una postura teórica específica hacia la narración" (p. 28). ${ }^{38}$ De esta manera no se trata solamente de la estructura del objeto ${ }^{39}$ (secuencias de acción o diseño de eventos) sino "de una forma de hablar, de manipular el tiempo, de usar el lenguaje figurativo, de los eventos constitutivos y el contexto de la performance en el que se produce la narración" (p. 28). ${ }^{40}$

La noción de voz, como uno de los criterios básicos de la narración, implica la reformulación del distanciamiento del sujeto y la definición de la narrativa como un enunciado narrativo, entendido como el discurso oral o escrito que asume la relación de un suceso o de una serie de sucesos (Genette, 1972, p. 71). ${ }^{41}$ Para Abbate, ciertos gestos experimentados en la música constituyen una voz narradora, y si bien son gestos que tienen su origen en la Ópera, resonaron también en la música instrumental del siglo XIX. La música tiene momentos de diégesis: "voces musicales que nos distancian de la materia sensual que estamos escuchando, que hablan a través de ella" (1991, p. xii). ${ }^{42}$ En lugar de la "voz del compositor", la autora prefiere "una visión auditiva de la música animada por múltiples voces descentradas localizadas en varios cuerpos invisibles (...) una interpretación de la música que otorga presencia humana a los objetos o fenómenos no humanos" (p. 13). ${ }^{43}$

Como hemos mencionado en el capítulo anterior, Abbate es más conocida por argumentar que la música no puede expresarse como lo hace el lenguaje verbal. En su trabajo, en cambio, discute la performance musical, aunque no aborda a performers o performances particulares: su discusión -dice ella- es en un sentido figurativo.

Tanto Rink, como Meelberg y Abbate se refirieron a la música entendida de un modo análogo en relación a categorías de la narrativa literaria que se corresponden a personas -en lugar de estructuras o recursos del lenguaje-: narrador, focalizador y voz narradora. En el primero se enfatiza la narración de un mensaje, en el segundo en la

${ }^{37}$ Cuando dice gestos, se refiere a inflexiones que pueden percibirse como enunciados de personas (p. ix).

${ }^{38}$ La traducción es nuestra.

${ }^{39}$ Abbate se refiere al objeto de la narración literaria como la historia.

${ }^{40} \mathrm{La}$ traducción es nuestra.

${ }^{41}$ La traducción es nuestra.

${ }^{42}$ La traducción es nuestra.

${ }^{43}$ La traducción es nuestra 
incidencia de una subjetividad en el sonido, y en la tercero a los enunciados de una Voz narrativa. A continuación, presentamos evidencias acerca de la aparición de (i) proto-estructuras comunicativas, (ii) regulaciones intersubjetivas y (iii) contornos vocales, que ocurren antes del desarrollo del lenguaje y que pueden informar a los tres enfoques.

\subsection{La performance como comunicación intersubjetiva}

El modo interpersonal de la comunicación entre bebés y adultos es uno de los temas de la Psicología del Desarrollo, en estrecha vinculación con los modos narrativos que desarrollamos desde el nacimiento. Desde esta perspectiva, encontramos una mirada hacia instancias anteriores a la adquisición del lenguaje: estructuras afectivas que pueden organizar el tiempo, la comunicación y la performance en un mundo cultural en formación.

\subsubsection{Formas proto-narrativas}

Tiempo después que semiólogos como Nattiez (1990) rechazaran la posibilidad de considerar a la música como narrativa argumentando imposibilidades semánticas, Imberty (1997) adoptó un enfoque experiencialista a partir de una serie de estudios realizados en el marco de la psicología del desarrollo que lo llevaron a proponer una serie de proto categorías anteriores a la adquisición del lenguaje, entre las que destacamos la proto-narrativa. Las cualidades dinámicas que regulan el afecto y la emoción como algo compartido se constituyen como maneras de estar con el otro, las cuales Imberty asoció a los a vectores dinámicos de la música, argumentando que pueden ser entendidos como sucesivas alternancias de tensiones y distensiones, así como también repeticiones y variaciones en la estructura temporal de una pieza musical.

\subsubsection{Musicalidad Comunicativa}

Años más tarde, en el marco de los estudios de la temprana infancia, una corriente que combina la cognición corporeizada (embodiment), la psicología corporeizada y la perspectiva de segunda persona se ocupó de estudiar los intercambios de la díada adulto-bebé, entendidos como una comunicación. Este abordaje destaca las relaciones entre los procesos dados a escala ontogenética y filogenética, y los estudia apoyándose en la música para analizar y entender los intercambios interpersonales. La música, como un modo expresivo culturalmente organizado, es entonces la base para definir a la musicalidad comunicativa como un dominio cognitivo específico de la especie (Malloch y Trevarthen, 2009). 
El rasgo de la musicalidad está presente en una cantidad de comportamientos que caracterizan la cognición humana, trascendiendo lo que es exclusivamente sonoro para adentrarse en el ritual, la dramatización y la danza. Tales intercambios tempranos pueden entenderse como performances interactivas que brindan oportunidades para involucrar al infante en aspectos estéticos de su cultura, y que serán clave para más adelante comprenderla y participar en ella. En ausencia del lenguaje, el habla de los primeros intercambios adquiere formas de contornos melódicos que son variados en su entonación vocal, en modos que se asemejan a organizaciones morfológicas de la música (Español, 2010). Estudios realizados analizaron la composicionalidad de las interacciones haciendo uso de las herramientas del análisis musical, identificando construcciones narrativas a partir de un motivo básico que es sujeto a elaboraciones (Martínez, 2007).

Se considera que estas interacciones no son específicamente musicales sino proto-musicales, y se entienden como la base para la enculturación y el posterior desarrollo de la musicalidad (en la vida adulta) de modos más formalizados. Tres rasgos que caracterizan a la musicalidad comunicativa son: el pulso, la calidad y las narrativas. Las narrativas aluden al modo en el que los sonidos se organizan en patrones de duración, altura, intensidad y timbre, se despliegan en el tiempo y le dan sentido a la interacción. Atañen, de esta manera, a una configuración co-diseñada de los elementos que la constituyen y a su significado sentido (Español, 2014).

La musicalidad comunicativa es atribuida entonces al desarrollo del lenguaje; se destacan sus aspectos comunicativos y el lugar de la narrativa para la organización de patrones de significado expresivo, más allá de su contenido musical específico.

\subsubsection{El performer como narrador y la comunicación intersubjetiva con el oyente}

En su tesis, Shifres (2007) exploró la comunicación de la estructura musical entre performers y oyentes -en particular la estructura prolongacional definida por Schenker ([1935] -1979)-, en performances de obras para piano del siglo XIX. A través de los análisis de las performances y tests de audición, realiza un abordaje de la comunicación en la interpretación que combina aspectos musicológicos y psicológicos de la performance. Partiendo de la perspectiva de la performance objetiva, se aproxima a una perspectiva comunicacional de la estructura con un marco narrativo e intersubjetivo de la psicología del desarrollo en la temprana infancia.

Su abordaje de la performance está influido por la idea de música como performance de Cook (2003) y la de la Musicalidad Comunicativa (Malloch, 1999/2000; Trevarthen 1999/2000). De este modo, considera el impulso narrativo de las condiciones psicogenéticas para desarrollar "una actividad imaginativa que por un lado 
caracteriza la construcción de la performance, concebida como una obra de arte independiente, $y$, por otro lado, organiza la recepción que el oyente tiene de ésta" (Shifres, 2007, p.18). ${ }^{44}$ Esta comunicación entre el performer y el oyente es entendida como una experiencia intersubjetiva que se despliega de un modo narrativo. En este contexto comunicativo, el narrador puede identificarse con el rol del performer, cuya función es la de "guiar la narración como una experiencia compartida, dando surgimiento a la presencia de un otro" (p. 288). ${ }^{45}$

\subsection{La narración en la psicología social: mundos posibles}

En Realidad Mental y Mundos Posibles, Bruner presenta el desarrollo de la narración en un contexto cultural, tomando algunos aspectos de la narración literaria, pero también en un marco más amplio de la vida, donde la narración participa en el pensamiento: la construcción de mundos posibles. El autor se apoya en la filosofía constructivista de Goodman (1984), la intersubjetividad temprana de Trevarthen (1979), y la lectura como acto de Iser (1978) para dar cuenta de interacciones, transacciones y regulaciones sociales que permiten la interpretación de relatos verosímiles en el contexto de una cultura (Bruner, 1986).

En principio, Bruner afirma que el pensamiento posee dos modalidades para ordenar la experiencia y construir la realidad; ambas son importantes y a la vez complementarias, pero sin embargo se diferencian en sus principios funcionales y sus criterios de corrección. La primera es la modalidad paradigmática o lógico-científica, que se ocupa de causas generales y cumple con el ideal de un sistema matemático, formal, de descripción y explicación; establece categorías y conceptos, persigue la coherencia y la no contradicción. La segunda es la modalidad narrativa que produce relatos que convencen por su semejanza con la vida, no buscan establecer una verdad sino más bien una verosimilitud. Ambas modalidades además suponen una aplicación imaginativa. Para Bruner, la aplicación imaginativa para la modalidad narrativa:

Se ocupa de las intenciones y acciones humanas y de las vicisitudes y consecuencias que marcan su transcurso. Trata de situar sus milagros atemporales en los sucesos de la experiencia y de situar la experiencia en el tiempo y el espacio. (...) La modalidad paradigmática, por el contrario, trata de trascender lo particular buscando niveles de abstracción cada vez más altos, y al final rechaza en teoría todo valor explicativo en el que intervenga lo particular. La lógica está desprovista de sentimiento: uno va, en general, a donde lo llevan sus premisas, conclusiones y observaciones, aún con algunas de las faltas de percepción a las que también los lógicos son propensos. Los científicos, tal vez porque confían en las historias familiares para llenar las lagunas de sus conocimientos, tienen un trabajo más difícil en la práctica. Pero

\footnotetext{
${ }^{44}$ La traducción es nuestra.

${ }^{45}$ La traducción es nuestra.
} 
su salvación reside en eliminar las historias cuando pueden reemplazarlas por causas. (Bruner, 1986, p. 13). ${ }^{46}$

De esta manera, el autor introduce la diferencia entre lo real y lo posible. Para él, la mejor definición de narrativa es una que resulte lo menos rígida posible: "la narrativa se ocupa de las vicisitudes de la intención (...) la intención es inmediata e intuitivamente reconocible: no parece requerir para su reconocimiento ningún acto interpretativo complejo por parte del espectador." (p. 17) ${ }^{47}$

Partiendo de la consideración que ningún texto o relato puede interpretarse en un solo nivel -una cuestión de la lingüística clásica y la interpretación de los textos bíblicos-, Bruner afirma que si queremos extraer el significado literario de un texto debemos leer e interpretar de una manera múltiple. Aunque el texto real permanece igual, en el acto de la lectura varía casi permanentemente debido a un "conflicto de géneros" que se produce cuando las diferentes maneras de leer o interpretar se "atacan mutuamente", dando como resultado la creación de lo que Iser (1978) denominó el texto virtual. Al respecto de la relación entre el texto y el lector, considera que:

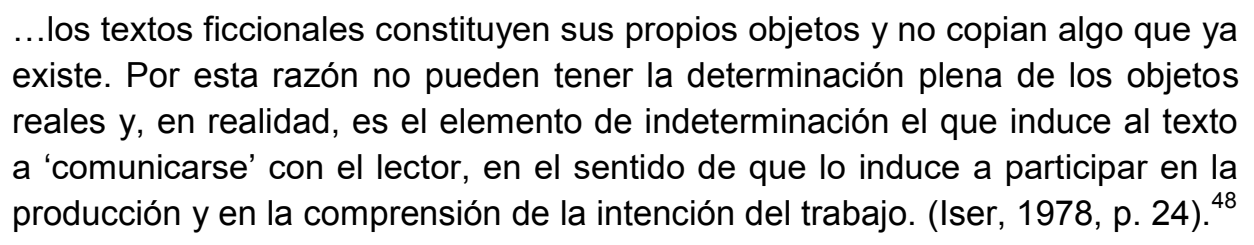

Para Iser, la indeterminación relativa de un texto permite un espectro de actualizaciones y así "los textos literarios inician 'performances' de significados en lugar de formular realmente significados en sí" (1978, p. 27) ${ }^{49}$. Entonces, según Bruner, la narración como acto de habla implica "un enunciado o un texto cuya intención es iniciar y guiar una búsqueda de significados dentro de un espectro de significados posibles" (Bruner, 1986, p. 25). ${ }^{50}$

Este tipo de compromiso es el que Bruner afirma que depende de tres características del discurso para que el lector pueda "escribir" su propio texto virtual: (i) el desencadenamiento de la pre-suposición; (ii) la subjetificación; y (iii) una perspectiva múltiple. Los tres juntos logran subjuntivizar la realidad: estar en el modo subjuntivo es

\footnotetext{
${ }^{46}$ La traducción es tomada de la edición en español. Bruner, J. (2004). Realidad Mental y Mundos Posibles. Los Actos de la Imaginación que Dan Sentido a la Experiencia (B. López, trad.) Barcelona: Gedisa, p. 25.

${ }^{47}$ Ibid, p. 29.

${ }^{48}$ La traducción es nuestra.

${ }^{49}$ La traducción es nuestra.

${ }^{50}$ La traducción es tomada de la edición en español. Bruner, J. (2004). Realidad Mental y Mundos Posibles. Los Actos de la Imaginación que Dan Sentido a la Experiencia (B. López, trad.) Barcelona: Gedisa.
} 
estar intercambiando posibilidades humanas y no certidumbres establecidas. Es por esto que para Bruner (1986) un acto de habla narrativo "logrado" o "aceptado" implica la producción de un mundo subjuntivo.

El hecho de asumir que no existe una realidad "prístina" permite entender que los humanos construyen sus mundos. Desde el comienzo de la interacción humana, entre bebés y adultos encargados de su cuidado, las interacciones les permiten predecirse mutuamente, atribuyendo intenciones e interpretaciones de actos y expresiones del otro. Casi todos nuestros acercamientos al mundo están mediados por la negociación con otros, constituyendo un self transaccional. Los usos más simples de la comunicación aparecen en escena antes que el lenguaje, en este tipo de interacción que Trevarthen (1979) llama intersubjetividad incluye acciones como pedir, indicar, aliarse y que se realizan mediante el gesto, la vocalización y el lenguaje corporal.

De esta manera, una comunicación se establece con el supuesto del oyente acerca de que el hablante intenta comunicar algo (Sperber y Wilson, 1977). El desarrollo del lenguaje se sustenta en las regulaciones mutuas de los estados afectivos que permiten aprehender el significado dentro de las realidades sociales construidas conjuntamente en el marco de una cultura que los produce.

Construímos el mundo a partir de otros mundos, creados por otros, y a los cuales hemos tomado como ya dados: "Toda versión del mundo construída previamente puede tomarse como dada para las construcciones siguientes. Así, en efecto, la construcción de mundos implica la transformación de los mundos y las versiones del mundo ya hechas." (Bruner, 1986, p. 97). ${ }^{51}$ Bruner toma estas ideas de Goodman (1984), quien en su libro Of Mind and Other Matters defiende la filosofía constructivista. En la distinción entre versiones y mundos, Goodman intenta evitar el relativismo que supone abandonar la posibilidad de una realidad pristina: "debemos buscar la verdad no en la relación entre una versión y su referente externo, sino en las características de la versión misma y sus relaciones con otras versiones..." (Goodman, 1984, p. 37 en Bruner, 1986, p. 98). ${ }^{52}$

Según Bruner (1990), una cultura se está recreando constantemente al ser interpretada y renegociada por sus integrantes: los significados surgen de compartir las cogniciones humanas. Como participantes de una cultura, el significado se vuelve público y compartido; esta forma de vida adaptada culturalmente depende de esos conceptos compartidos y también de formas de discurso que utilizamos para negociar diferencias de significado e interpretación.

\footnotetext{
${ }^{51} \mathrm{Ibid}, \mathrm{p} .104$.

52 Ibid, p. 106.
} 


\subsection{La narración en la cognición social: consciencia narrante}

Popova propone una comprensión de la narrativa literaria como una forma de cognición social y sitúa el estudio de tales narrativas en relación con un nuevo enfoque integral de la enacción para explicar la cognición humana. El enfoque enactivo inicialmente enfatizó el vínculo indeleble entre los procesos cognitivos y la actividad corporeizada de un organismo (Varela, Thompson y Rosch, 1991); posteriormente, el enactivismo sensoriomotor (Noë, 2004, 2010), explicó el conocimiento práctico característico de la percepción, entendida como un proceso de interacción entre un organismo y su entorno. La autora afirma que son las interacciones sociales, en lugar de las sensoriomotoras, las que dominan ciertas prácticas humanas, específicamente la producción y recepción de narrativas. La forma particular de cognición enactiva que se propone para el entendimiento narrativo es la del hacer sentido en un modo participativo $^{53}$ (De Jaegher y Di Paolo, 2007), describiendo la narrativa como una forma de proceso intersubjetivo de hacer sentido entre dos agentes: un narrador y un lector. Dar sentido a la literatura narrativa es un proceso interaccional de coconstrucción de un mundo del cuento ${ }^{54}$ con un narrador (Popova, 2014).

La autora parte contextualizando el mundo humano en el que interactuamos a través de la acción práctica. Al referirse a las acciones, no considera al mero movimiento sino a una accion deliberada y auto-consciente para perseguir un objetivo o meta específicos. Esta fenomenología de la agencia implica una intencionalidad que poseemos y que recíprocamente entendemos que los otros poseen. La agencia no es la habilidad simple de actuar en el mundo: son creencias, deseos e intenciones que tenemos y asumimos entonces que los demás tienen.

En la experiencia humana las acciones físicas y el movimiento son entendidos de acuerdo a la dinámica social: una acción intencional significativa se toma para conectar con otra acción significativa; la percepción de ésta causalidad es la que nos permite entender las narrativas y no la mera causalidad temporal. Esta causalidad perceptiva (Michotte, 1963), que da sentido a las interacciones sociales es la que permite comprender la causalidad narrativa de los relatos: es una forma de interpretación de la experiencia en la que nos involucramos espontánea y automáticamente (Popova, 2015).

Entender una narrativa no es tan diferente de cómo entendemos a las personas: las historias se entienden mejor como procesos de interacción modelada entre esencialmente dos participantes: un lector y un narrador. Tomando a la idea de

\footnotetext{
${ }^{53}$ El término en su idioma original es participatory sense-making.

${ }^{54}$ En el original, usa la palabra story-world
} 
Paul Ricoeur, -el acto de leer es el que siempre completa el trabajo de una narración-, la autora dice que la comprensión narrativa es un proceso dialéctico entre lo que revela un texto y lo que un lector se apropia en el proceso de lectura, y lo vincula al proceso de hacer sentido en un modo participativo. Cuando Popova propone una interacción se refiere a una forma participativa del lector, en oposición a una historia pre-dada que debe comprenderse; de la misma manera entiende que los significados son construidos socialmente y no meramente recuperados.

En ese sentido considera entender la narrativa como virtual: "es un proceso interaccional de co-construir un mundo de la historia con un narrador. (...) el lector enactúa una consciencia interpretada/inferida como una voz narradora 'que habla', y un reflector narratorio 'que ve' (incorporando, por lo tanto, una teleología narrativa general)" (Popova, 2015, p. 9) ${ }^{55}$ Atribuimos una intención a lo que denomina una consciencia narrante y a la estructura de acción que integra la sucesión de eventos en una causalidad que se dirige hacia una meta: la meta del narrador.

Es posible definir la narración a partir de tres elementos: causalidad, agencia narradora y enacción del punto de vista narratorial: "al atribuir la causalidad a una serie de acontecimientos, estamos enactuando un punto de vista narratorial específico" ( $p$. 14). ${ }^{56}$ Cuando leemos narraciones escritas las estamos enactuando; las conferimos a un orador que "tratamos como un participante conversacional, nos convertimos en participantes dispuestos en sus mundos, pero también ellos se convierten en parte del nuestro." (p. 76). ${ }^{57} \mathrm{Al}$ decir enactuamos, se deduce que re-creamos una situación, un momento, un acto para entenderlo.

Más allá de como lo llamemos (narrador, autor implícito, orador), hay un otro que el lector construye; algún tipo de participante conversacional en el proceso de lectura, una consciencia mediadora entre sí mismo y los eventos reportados. Popova dice que el narrador es entonces "una instancia ficcional, aunque psicológicamente real, una instancia enunciatoria de un acto de contar, y contar es, desde mi visión, una forma de interacción." (p. 62). ${ }^{58}$

\subsection{Síntesis: acerca de lo narrado en la performance}

En este capítulo hemos presentado un cambio de perspectiva con respecto al capítulo anterior en la consideración análoga entre la música y la narración: en primer lugar, (i) este cambio se debe a la localización de la performance en el centro -en el lugar de la obra o texto musical- para establecer las analogías; luego, vimos que (ii) los

\footnotetext{
55 La traducción es nuestra.

56 La traducción es nuestra.

57 La traducción es nuestra.

${ }^{58}$ La traducción es nuestra.
} 
estudios de la psicología del desarrollo entienden a la proto-narrativa como una instancia previa a la adquisición del lenguaje que incluye aspectos proto-musicales; por último, (iii) tanto la perspectiva de la psicología social como la cognición social sitúan a la narración en lugar de la narrativa -esta última concebida desde las categorías del análisis narratológico-, enfatizando el acto de narrar y la interpretación enactiva de los textos. Finalmente, expusimos propuestas realizadas por investigadores para el abordaje de la analogía entre narración y performance. Todas ellas presentan un enfoque particular con respecto a la performance y a los performers, entendidos ambos en el contexto de una narración, y sus aspectos serán tenidos en cuenta como posibilidades de respuesta a nuestras hipótesis.

Sin embargo, a diferencia de lo que en esta tesis se propone, estos investigadores realizan estudios basados en el análisis de grabaciones de performances, y no parecen contemplar otro punto de vista excepto el del investigador. Nosotros preferimos indagar en las palabras de los músicos, para permitir que sean ellos mismos quienes describan sus acciones, y luego considerar las posibles analogías a partir de concepciones informadas por la práctica, desde el punto de vista del performer y su experiencia.

\subsubsection{Perspectivas sociales de la narración: la comunicación}

Al argumentar la imposibilidad de la música de ser narrativa, su incapacidad para significar y su falta de recursos verbales fueron planteados como los argumentos centrales. Sin embargo, la psicología del desarrollo permite entender a las primeras instancias en la comunicación madre-infante como proto-narrativas, ya que son anteriores al lenguaje.

Las proto categorías que se ponen en relieve se estudian en la adquisición del lenguaje y ocurren en instancias de socialización durante la comunicación intersubjetiva temprana. Estos intercambios, en ausencia de significaciones verbales constituidas, presentan sonidos y contornos que son entendidos de modo análogo a la música, tomando en préstamo sus categorías. Allí, la comunicación verbal no es requerida, y las interacciones son entonces estudiadas en términos de performances, donde se enfatiza la actuación como sonido y movimiento, a la manera de formas primitivas de la música como el ritual, la dramatización y la danza.

Esta perspectiva permite entender que existe una posibilidad de considerar una base musical en formas primitivas del lenguaje, que se vincula fundamentalmente con los "actos" de habla más que con la significación del texto o de las posibilidades semánticas del lenguaje. Entonces, en primer lugar encontramos que la analogía entre 
narración y música puede ser entendida desde la primera hacia la segunda, pero que también puede ser entendida a la inversa, razón por la cual argumentamos aquí que al abordar la performance musical no se requiere necesariamente que la música iguale al lenguaje para luego proponer una analogía posible.

Sin embargo, ¿cómo debemos considerar lo narrado en la performance musical? Si la música no tiene palabras y el oyente no la entiende en estos términos, no quiere decir que no se esté narrando y comunicando. Lo narrado podría ser algo construído en la interacción intersubjetiva, o surgir de otra manera entre performers y el público. En esta tesis consideramos que partir desde la analogía del performer y su intencionalidad comunicativa nos permitirá entender mejor la analogía de la música como narrativa, en lugar de partir desde la obra musical y convocar luego a las categorías del análisis narrativo. Entonces, una de las temáticas de esta investigación se orienta hacia entender qué es lo que el performer está entendiendo y comunicando de la obra para indagar lo narrado en la performance.

\subsubsection{Mediación 1: el performer como lector}

En la narrativa literaria, el rol del lector implica que el acto de leer completa la narración, del modo en que es concebida como un asunto entre el narrador y el narratario (Ricoeur, 1984, 1985, 1988) . En la música, la presencia del texto musical ha llevado a muchos autores a entender a la partitura y al texto musical en términos análogos al texto literario. Del mismo modo que en una narración literaria la historia no es algo pre-dado que el lector entiende de manera directa a partir del contenido del texto (Popova, 2015), en la música el texto musical no puede contener todos los aspectos de una obra (Boorman, 1999),

Más allá de la pertinencia de entender a ambos textos en términos análogos, el asunto que nos ocupa aquí es abordar el rol del performer en su actividad de lector y productor de lo que el oyente finalmente recibe en la obra como sonido. Si bien la obra musical podría interpretarse como algo cerrado, autosuficiente y absoluto, el performer -quien lee la partitura- participa, no obstante, en la producción sonora de la obra desde la lectura e interpretación del texto, algo que podría entenderse en términos de una función mediadora del narrador entre la obra y el público. ${ }^{59}$ Rink (1994) sostiene que en el estudio de la partitura el performer revela un mensaje particular inherente en ella y realiza su traducción en sonido, ambas acciones vinculadas a una interpretación de la obra que se llevará a cabo en la performance.

\footnotetext{
${ }^{59}$ En el capítulo 3 hemos mencionado la función mediadora del narrador señalada por Nattiez, entre la historia y el lector.
} 
Al entender que el lector participa completando la narración, desde la perspectiva social (de la psicología y la cognición) se plantea que existe un tipo de relación dinámica con el texto: en primer lugar, los textos inician performances de significados cuando invitan al lector a 'participar' en la búsqueda de significados posibles (Bruner, 1986); en segundo lugar, el narrador y el lector son entendidos como agentes en la construcción 'participativa' del sentido (Popova, 2014); mientras que en la música cuando el performer toca establece un diálogo continuo entre la arquitectura integral y el "aquí y ahora" (Rink, 1999); y durante la performance el performer en tanto narrador puede guiar la narración como una experiencia 'compartida', dando surgimiento a la presencia de un otro (Shifres, 2017).

Estos cuatro enfoques (los dos primeros en relación a la lectura, los dos últimos a la performance musical) pueden ser entendidos como interacciones culturales en una construcción social de significados, sugiriendo interacciones tales como: (i) la creación o escritura de un texto virtual; (ii) la enacción de una agencia o consciencia narrante; (iii) un diálogo entre una estructura del pasado y el presente; y (iv) la experiencia compartida entre el performer y la presencia de un otro. Sin embargo, no podemos considerar que estas interacciones sean reales, sino que pueden ser entendidas como construcciones que pueden realizarse a partir de atribuciones de intencionalidad humana. En vistas de considerar la existencia de estos participantes conversacionales virtuales, podemos tenerlos en cuenta en la experiencia del performer si los consideramos como instancias posibles de ser psicológicamente reales (Popova 2015).

Por todo lo anteriormente expuesto, en esta tesis consideramos que no deberíamos estudiar al performer como narrador únicamente en la performance in situ, sino que existen una gran cantidad de acciones intencionales a indagar que se ponen en juego en la lectura para la interpretación de la obra desde el primer contacto con la partitura. $Y$ si es posible atribuir significado narrativo a partir de intenciones humanas enactuadas, entonces debemos indagar cómo el músico puede estar construyendo o re-construyendo la obra a partir de enacciones reales o virtuales durante la preparación de la performance.

\subsubsection{Mediación 2: narrador, voz narrativa y focalización}

En este capítulo hemos presentado enfoques que consideramos un cambio de perspectiva para la relación análoga entre narración y música. Esto se produce principalmente cuando el texto musical de la partitura es dejado a un costado para considerar a la performance musical en el centro de la analogía. 
Estos enfoques enfatizan otro tipo de relaciones entre el compositor, la obra y el performer, donde se considera el rol decisivo del tercero: (i) Abbate (1991) propone que la música es escrita por el compositor pero hecha por los performers; (ii) Meelberg (2006), haciendo énfasis en la focalización, afirma que cada performance de una misma obra resulta en una nueva narrativa; (iii) Rink (1994) sostiene que es el performer quien determina el contenido narrativo esencial de la música; y (iv) Shifres (2007) habla de la performance en términos narrativos como una obra de arte independiente creada a partir de la composición. Si bien todos los enfoques presentados vinculan a la narración con la performance, sólo Rink y Shifres postulan al performer como un narrador.

Meelberg plantea que el performer no iguala al narrador porque entiende que su función es la de emitir los signos, y en cambio considera que es más apropiado entender a la performance como una focalización. Sin embargo, el autor no contempla que tanto el narrador, el actor y el focalizador pueden superponerse en el texto (Bal, 1997). En esta tesis contemplamos a la focalización como analogía posible para la performance de la música, pero también estaremos abiertos a la posibilidad de la 'convivencia' de varias personas o funciones sociales dentro en la performance, de un modo análogo a como ocurre en la narración, con el objetivo de no pensar a la performance como un asunto exclusivo del performer.

Según Abbate (1991), la presencia de una voz en la performance permite descentrar la voz del compositor en varios cuerpos invisibles, una interpretación de la música que otorga presencia humana a los objetos o fenómenos no humanos. La noción de voz también fue enunciada por Rink (1994) cuando definió al performer como narrador, haciendo referencia a la voz narrativa y al mensaje emocional en la performance. $^{60}$

En esta investigación, la variedad de enfoques en estos cuatro autores nos sirve para contemplar un campo de posibilidades para pensar al narrador en la música desde su producción sonora y a la performance como un todo (sonido y acción). Ya sea pensando en un narrador o focalizador, lo importante aquí es abordar a la performance como un acto narrativo de comunicación. Entonces, esta tesis fundamentalmente se preguntará ¿quién habla? para indagar en la analogía del narrador.

\footnotetext{
${ }^{60}$ En referencia a las Baladas de Chopin, Rink dijo: "me pregunto si la voz narradora oculta en estas obras (y quizás en cualquier composición) pertenece en gran parte al performer, quien, como "narrador de cuentos", determina el contenido "narrativo" esencial de la música siguiendo las indicaciones en la partitura... (...) Ciertamente, en el acto de la performance uno es consciente de comunicar algo a una audiencia, no por supuesto una historia o programa en el sentido habitual, sino algún tipo de mensaje emocional, como sea que se manifieste o conciba, lo cual, como una "voz" imaginada y sublimada, le habla a uno a través de la música mientras toca" (Rink, 1994, p.112).
} 


\subsubsection{Mediación 3: narraciones posibles}

Por último, repasaremos los mundos posibles de Bruner (1986). En referencia a los textos narrativos, el autor contrapone el texto real al texto virtual, bajo el supuesto de que ningún texto puede ser interpretado en un solo nivel. Del mismo modo en que un texto literario real siempre permanecerá igual, podríamos pensar que las partituras (los textos musicales) también, y por lo tanto considerar a las performances musicales como los 'textos' virtuales posibles.

La modalidad narrativa del pensamiento produce relatos que convencen por su semejanza con la vida, no buscan establecer una verdad sino más bien una verosimilitud. Estos significados posibles se sustentan en el modo subjuntivo de estar intercambiando posibilidades humanas y no certidumbres establecidas (Bruner, 1986). Algo que destacamos aquí del enfoque de Bruner es que construimos nuestros mundos a partir de otras construcciones, otros mundos creados por otros. En esta tesis, nos comprometemos con esta idea y entonces indagamos a la performance musical como una construcción para entender cómo se construye a partir de otras construcciones. 
PARTE 2

Estudios 


\section{ASPECTOS METODOLÓGICOS}

A continuación presentamos los lineamientos metodológicos que sigue esta tesis. Partimos de los objetivos y fundamentos generales de la investigación cualitativa para adentrarnos en la entrevista como un instrumento específico para obtener información. Debido a que éste es un estudio de entrevistas, consideramos que antes de abordar cada entrevista realizada era necesario desarrollar un capítulo en donde se contextualice la metodología empleada y se expliquen los motivos de dicha elección.

Luego, describimos el plan metodológico que se llevó a cabo para organizar la investigación, su diseño, la caracterización de los participantes de las entrevistas, así como los procedimientos para llevarlas a cabo y la consideración de los datos en el análisis.

\section{La investigación cualitativa}

Los métodos cualitativos son comúnmente entendidos en dos sentidos: el primero es en sentido contrapuesto a los métodos cuantitativos, y el segundo se refiere a la metodología de uso en las ciencias sociales. En cuanto a su rango de aplicación, es utilizada en investigaciones de disciplinas como la sociología, la psicología, así como también en los estudios de educación y estudios culturales, entre otros (Flick et al., 2004).

Según Taylor y Bogdan (1984), el término metodología designa el modo en que enfocamos los problemas y buscamos las respuestas. En lugar de perseguir los hechos o causas de los fenómenos sociales con independencia de los estados de las personas, la investigación cualitativa aborda el lado subjetivo de la vida social, de acuerdo al modo en que las personas se ven a sí mismas y a su mundo. La importancia de lo real reside entonces en aquello que las personas perciben como tal: el modo en que experimentan el mundo y las fuerzas que las mueven (ideas, sentimientos y motivaciones internas) (Taylor y Bogdan, 1984).

Los investigadores utilizan esta metodología para desarrollar conceptos, intelecciones y comprensiones partiendo de los datos. Conocen los efectos que causan en las personas que estudian, por eso tratan de relacionarse de un modo no intrusivo e intentan controlar o reducir estos efectos, o al menos entenderlos cuando interpretan los datos. El modo de comprender se realiza dentro del marco de referencia de las personas, se identifican con ellas para estudiar cómo ven las cosas. 
De esta manera no se mantienen distanciados de ellas, se acercan suspendiendo o apartando sus propias creencias, perspectivas y predisposiciones para verlas como si ocurrieran por primera vez. Los investigadores cualitativos no ponen énfasis en los controles estadísticos sobre la base de la reducción de los actos y dichos de las personas; realizan, sin embargo, una investigación sistemática conducida por procedimientos precisos. Al asegurarse un ajuste estrecho entre los datos y lo que la gente dice o hace, se permite dar énfasis a la validez de la investigación (Taylor y Bogdan, 1984).

Taylor y Bogdan se centran en dos enfoques teóricos que caracterizan a la perspectiva fenomenológica, pertenecientes a una amplia gama de marcos y escuelas de pensamiento en las ciencias sociales: el interaccionismo simbólico y la etnometodología. ${ }^{61}$

El interaccionismo simbólico se apoya en la importancia de los significados sociales que las personas asignan al mundo que las rodea. La acciones humanas no responden a estímulos o guiones culturales: las personas actúan respecto a las cosas y a las otras personas sobre la base los significados que éstas tienen para ellas. Los significados son productos sociales que surgen durante la interacción, y los actores sociales son los que asignan significados a través de un proceso de interpretación: este proceso "es entendido como un intermediario entre los significados o predisposiciones a actuar de cierto modo y la acción misma. Las personas están constantemente interpretando y definiendo a medida que pasan a través de situaciones diferentes." (Taylor y Bogdan, 1984, p. 25).

La perspectiva interaccionista simbólica considera que todas las organizaciones, culturas y grupos están conformados por actores implicados en un proceso constante de interpretación del mundo que los rodea. Sus interpretaciones y definiciones de la situación son las que determinan sus acciones. Las diferencias entre los dichos y las acciones de las personas se deben a que cada uno ha tenido diferentes experiencias donde aprendió diferentes significados sociales; por otro lado, se entiende que actúan diferente porque se encuentran en situaciones diferentes.

Para la etnometodología, los significados son un logro práctico por parte de los miembros de la sociedad. Los etnometodólogos dejan atrás su propia creencia en la realidad para estudiar la realidad de la vida cotidiana, y comprender cómo las personas mantienen un sentido de la realidad externa. Por eso, se encargan de examinar los modos en que las personas aplican reglas culturales abstractas y percepciones de sentido común a situaciones concretas, y por lo tanto tratan de

${ }^{61}$ Sin embargo, enfatizan en que éstos no son los únicos que la integran. 
entender cómo las personas ven, describen y explican el orden del mundo en el que viven.

En este estudio adoptamos una metodología cualitativa para conocer la actividad de los performers entendidos como personas en un contexto social y cultural. Para conocer el punto de vista y aspectos de la subjetividad de los músicos, el instrumento para obtener la información debe permitir al investigador establecer una relación intersubjetiva que permita indagar en la experiencia del músico de un modo no-intrusivo. Por lo tanto, hemos considerado la realización de entrevistas como instrumento metodológico.

\section{La entrevista}

\subsection{Aspectos generales}

Existen varios tipos de entrevista. El campo de la investigación social es variado y puede atravesar una gran cantidad de disciplinas específicas. Los estudios sociales pueden tener objetivos más o menos generales en el abordaje de las investigaciones o bien indagar aspectos puntuales de un grupo o comunidad, una profesión, una población específica o un sujeto individual. En términos generales, las entrevistas se utilizan para obtener información directa de los sujetos a través de sus relatos verbales. Existen sin embargo diferentes variantes dentro de lo que se podrían considerar entrevistas. Algunas suelen tener una mayor estructuración: tienen forma de cuestionarios o encuestas (de actitud o de opinión) con un orden predefinido que se administra a un grupo de sujetos. Este tipo de instrumentos busca un mayor control en la formulación de las mismas preguntas, o a partir de cómo están formuladas definen un tipo de respuesta, que a su vez permite que los resultados sean comparables (Taylor y Bogdan, 1984).

\subsection{Tipos de entrevista}

Valles (1997) ubica a las entrevistas dentro de lo que denomina las técnicas de conversación, que tienen bases en modos informales de interacción social como la conversación ordinaria o los diálogos de la vida cotidiana. En estos encuentros cotidianos de relación interpersonal presentan tres elementos básicos: (i) las personas; (ii) una situación; y (iii) las reglas de la interacción (Denzin, 1970). En pos del funcionamiento de la entrevista, el entrevistado debe percibir la situación como la de una conversación, más allá que la situación implique que uno de los dos esté dispuesto a hablar y otro a escuchar. Este tipo de charla es posible de ser realizada de 
un modo natural, aunque implícitamente es el entrevistador el encargado de organizar y mantener la conversación, animando al entrevistado a hablar (Caplow, 1956).

El modelo contextual de la comunicación de Gorden (1975) puede ser aplicado para entender el contexto social de la entrevista. El proceso comunicativo de obtención de la información depende de tres elementos internos a la situación de la entrevista (entrevistador, entrevistado y el tema en cuestión) y elementos externos a la situación que relacionan a la entrevista con la sociedad, la comunidad o la cultura. Esto deriva necesariamente en decisiones de diseño acerca de qué información comunicará el entrevistado, a quién y bajo qué condiciones, ya que según Gorden una vez empezada la entrevista poco puede hacerse para modificar la relación triádica de sus elementos internos.

Patton (1990) considera cuatro tipos o variaciones de la entrevista cualitativa, las cuales presentan diferentes grados de estructuración: (i) la entrevista conversacional informal, en donde las preguntas surgen en el curso natural de la interacción, sin selección previa de temas ni redacción previa; (ii) la entrevista basada en un guión, la cual se caracteriza por la preparación de la guía de temas a tratar, con la libertad del entrevistador en el orden y la formulación de las preguntas; (iii) la entrevista estandarizada abierta, que implica un listado de preguntas redactadas y ordenadas por igual para todos los entrevistados, de respuesta libre o abierta; y (iv) la entrevista estandarizada cerrada, similar al anterior tipo, con la diferencia en que el tipo de respuesta es cerrada (Patton, 1990).

A continuación, presentamos los tipos de entrevista que más se acercan a nuestros intereses metodológicos en esta investigación:

(i) Las entrevistas en profundidad, en tanto procesos comunicativos de extracción de información, suponen que ésta última se encuentra en la biografía de la persona entrevistada, y ha sido absorbida y experimentada por ella, por lo que será proporcionada con una orientación o interpretación que suele ser más interesante que una mera exposición cronológica o sistemática (Alonso, 1994).

(ii) La entrevista focalizada (Merton y Kendall, 1946) ofrece al investigador una posición ventajosa con respecto al análisis previo de la situación objeto de la misma. Los entrevistados son participantes que han estado expuestos a una situación concreta y la entrevista se centra en las experiencias subjetivas de las personas con respecto a dicha situación, por lo tanto se sustenta en un guión elaborado a partir del análisis previo del tema y sus hipótesis derivadas. Los entrevistadores no dirigen las respuestas, tratando que sean espontáneas o libres, sin embargo se alienta la especificidad en las respuestas del entrevistado (que sean concretas). Se indaga una amplia gama de evocaciones de la experiencia, y una 
profundidad (implicancias afectivas y carga valorativa) en un contexto personal (idiosincrasia, creencias e ideas).

(iii) La entrevista estandarizada no programada: en ella las preguntas suponen una estandarización del significado debido a que son formuladas en los términos familiares del entrevistado; sin embargo, no hay una secuencia de preguntas satisfactorias para todos los participantes, suponiendo que su preparación (de los entrevistadores) y selección (de los entrevistados) es lo que permite conseguir una equivalencia de significados.

(iv) La entrevista especializada y a elites no supone únicamente su realización a personalidades importantes, sino más bien a un entrevistado experto o bien informado. En estas entrevistas, se enfatiza la definición de la situación por parte del entrevistado, animándolo a estructurar el relato de la situación. El investigador desea permitir que el entrevistado le enseñe acerca de lo que quiere saber, de modo que el segundo pueda introducir las nociones que considera relevantes, en lugar de depender de las nociones del primero (Dexter, 1970). La entrevista en profundidad presenta una última categoría posible que integra a la entrevistas biográfica, intensiva y larga, entre otras, las cuales no abordaremos aquí.

(v) La entrevista abierta, se ubica en la función expresiva o emotiva debido a que el yo de la comunicación no es un yo lingüístico, sino un yo especular o social. A diferencia de las concepciones conductistas o utilitaristas que consideran un yo individualista o racionalizado, las concepciones constructivistas ven en la entrevista un yo narrativo, que cuenta historias en las que el yo se incluye como parte de la historia (Alonso, 1994).

Hemos dado cuenta de un amplio panorama con respecto a criterios y tipos de clasificación para las entrevistas cualitativas. Consideramos que cada una de ellas surge como un instrumento particular en término de los intereses de cada investigación. Sin embargo, el conocerlas realiza un aporte con respecto al conocimiento de una amplia gama de posibilidades y decisiones a tomar en relación a un tema de interés u objeto de estudio en una investigación: la 'naturaleza' del fenómeno social que se desea conocer, las preguntas que intenta responder, el tipo de información que desea obtener, y las posibilidades de obtenerlo; para así luego abordarlo a partir de las elecciones metodológicas de su análisis. A continuación, pasamos a desarrollar el plan metodológico que nos ocupará en esta tesis. 


\section{Plan metodológico}

En este estudio adoptamos una metodología cualitativa para conocer aspectos de la performance musical que, sin bien son específicos de la disciplina musical, son abordados aquí desde un enfoque social que busca entender la actividad del músico como sujeto en un contexto determinado. Los objetivos planteados en la investigación buscan acercarse a una visión del músico performer desde su propia perspectiva. De este modo, indagamos aspectos de su experiencia, abarcando sus acciones intencionales, sus motivaciones, su involucramiento personal, sus sentimientos y sensaciones, el vínculo con las demás personas, sus ideas y concepciones.

Adoptamos aquí el instrumento de la entrevista porque entendemos que estos aspectos a indagar difícilmente puedan ser abordados comprensivamente desde una perspectiva externa. Además, consideramos que la información que para nosotros es valiosa debe ser brindada y expresada por el músico en sus propias palabras, adoptando una metodología que sea lo suficientemente amplia con un grado moderado de estructuración, cuidando los aspectos humanos de toda relación social espontánea que supone la entrevista cualitativa.

La información a su vez es obtenida de manera directa a través de la interacción con el entrevistado, mediada por sus interpretaciones y su adecuación a la situación conversacional que mantiene con el entrevistador. Así, los significados surgidos son consensuados en la interacción entre el entrevistador y el entrevistado, del mismo modo que ocurre en procesos interactivos en la socialización, pero con las características particulares de la entrevista como un encuentro.

Hemos visto que los tipos de entrevistas que surgen de sus clasificaciones implican diferencias en cuanto a su estructuración y planificación, además de sus grados de direccionalidad en las preguntas y su grado de apertura en las respuestas. Las diferentes técnicas de conversación además suponen en cada caso cierta habilidad del entrevistador para adaptarse en cada situación conversacional de la mejor manera natural y espontánea posible.

De acuerdo a las características de la información que se desean obtener, este estudio cuenta con un análisis previo de las temáticas a abordar, apoyadas en el marco teórico y los trabajos de investigación relevados en él. A partir de la lectura y la reflexión acerca del tema, surgen ciertas preguntas que se dirigen a una serie de temáticas o tópicos de interés que sirven como categorías iniciales potenciales para la caracterización del tema. Las hipótesis planteadas se derivan del estado del arte con respecto a la analogía del performer como narrador y guían aspectos del diseño metodológico para la obtención de la información, a los que además incorporamos 
aspectos relevantes para el enfoque del estudio desde la perspectiva del músico (ver Capítulo 4).

Sin embargo, con el objetivo de obtener información descriptiva que permita caracterizar y desarrollar las analogías de las hipótesis, consideramos a estas últimas con un grado de apertura para poder abordar el análisis de la información sin presupuestos, esperando incorporar aspectos relevantes que no hayan sido contemplados de antemano. Esta apertura comienza en la actitud del entrevistador hacia el entrevistado y sus repuestas, con el compromiso de entender sus palabras (y sus maneras de decir) para acercarse a su punto de vista y mantener una conversación en dichos términos.

Debido a la necesidad de implementar una metodología que permita el análisis de las respuestas de todos los músicos de un modo integrado, ciertas decisiones fueron tomadas en relación al grado de estructuración de dichas conversaciones. Las preguntas permitieron un grado de apertura en las respuestas y consideraron el orden de las mismas en el curso de la conversación, así como una flexibilidad en el tiempo del desarrollo de las respuestas en cada caso.

Si bien el entrevistado encarna la perspectiva que se desea conocer, al entablar una conversación la información puede surgir también de la reflexión e indagación por parte de ambos. El entrevistado lógicamente es quien se dispone a compartir su punto de vista, pero del mismo modo permanece abierto a las inquietudes del entrevistador, quien guiado por su interés en conocer más, solamente llegará hasta donde el entrevistado lo permita, en la medida en que se sienta correspondido en el diálogo o acompañado en ese punto de vista. De esta manera entonces son entendidos tres elementos internos de la situación de la entrevista: entrevistado, entrevistador, y el tema en cuestión. Las situaciones externas a la entrevista son consideradas tanto por el entrevistador como por el entrevistado en el marco social y cultural de la práctica musical. Aunque posean experiencias y actividades diferenciadas, ambos conocen la práctica musical y comparten un lenguaje técnico, y expresiones que les son comunes.

Los instrumentos para la obtención de la información seo estructuraron en base a un guión que permitió abordar los temas principales relativos a cada entrevista. La conducción de las entrevistas supone que el entrevistador descarta las preguntas que ya han sido respondidas e introduce o re-introduce en el flujo de la conversación aquellas que han quedado pendientes por responder. Además, decidimos evitar plantear la conversación en términos confesionales, o evaluadores de la actividad profesional del músico, adoptando una posición desprejuiciada y abierta, respetando las instancias personales y el modo en que cada uno realiza su actividad disciplinar. 
Las entrevistas que realizamos en este estudio pueden ser consideradas en términos generales como entrevistas en profundidad. Las entrevistas se parecen al tipo de entrevista focalizada en tanto el investigador ha analizado previamente aspectos de la temática, aunque no de las situaciones concretas. Por otro lado, son semi-estructuradas o estandarizadas no programadas en tanto las preguntas son formuladas en términos familiares y no se presentan como una secuencia satisfactoria para todos los entrevistados. Son entrevistas especializadas o entrevistas a elites en términos de la selección de músicos que poseen experiencia acerca de la información y el punto de vista que se desea obtener, así como también en el grado de apertura para aprender de sus nociones y el enfoque en el desarrollo de sus temas. Por último, son de tipo biográfico en tanto abordan, aunque de manera superficial, aspectos de la vida y la formación del músico, así como también indagan en las relaciones interpersonales dentro de la práctica.

\subsection{Organización del estudio}

Esta investigación se desarrolla sobre una estructura de tres entrevistas cualitativas, administradas en base a un guión de diseño previo. Las entrevistas fueron pensadas como tres encuentros diferenciados de conversación y reflexión con los músicos. La separación en tres surge del análisis y la reflexión acerca del tema, con el objetivo de profundizar en ciertos grupos de temáticas relacionadas dentro de una misma entrevista.

Aunque todas ellas abordan aspectos de relevancia para la performance musical, los tres ejes centrales que organizan las entrevistas son: (i) la performance como intencionalidad, que aborda aspectos de la interacción social indagando a los agentes de la práctica musical; (ii) desde la preparación hasta la performance en público, que aborda la interpretación de las obras, la experiencia personal del performer y el rol del músico, aspectos que tienen lugar en la performance como comunicación; por último, (iii) la relación entre el performer y la obra, que profundiza en la interpretación y la performance de una misma obra a lo largo de una serie de presentaciones en público.

Originalmente pensado en tres encuentros con los músicos, se plantearon inicialmente las temáticas y el diseño de las dos primeras entrevistas. Luego de la realización, transcripción y análisis preliminar de las dos primeras, se propuso que la tercera entrevista permitiera profundizar en la descripción de algunos aspectos de las categorías emergentes en el análisis. 


\subsection{Entrevistador}

Las entrevistas fueron conducidas por el autor de la tesis: es músico, docente e investigador, desarrollando estas últimas dos en la disciplina musical. Durante las entrevistas, su experiencia permitió llevar adelante la entrevista y comprender las expresiones de los músicos debido a la disponibilidad de una serie de términos y concepciones comunes de la práctica y la cultura musical.

El investigador cuenta con 16 años de formación académica en el estudio del instrumento (guitarra), abordando repertorios instrumentales solistas (académicos), y de música de cámara. Además, tiene otros 20 años de experiencia en diversos grupos o formaciones musicales con las que realizó presentaciones en público (principalmente de música popular, ya sea tocando, o cantando y tocando). En estas formaciones se interpretan músicas compuestas por sus integrantes y/o de artistas que no las integran.

Como investigador, ha realizado durante los últimos años estudios con músicos en donde condujo entrevistas de diversos tipos. En el primero, la entrevista indagaba en dos aspectos: (i) un recorrido por la historia del aprendizaje del instrumento; (ii) los procesos cognitivos y las acciones llevadas a cabo en una tarea que era realizada con el instrumento (Tanco y Aún, 2013). En otro de los estudios, se realizaron videoentrevistas individuales breves a un grupo de alumnos universitarios para que describieran sus sensaciones comparadas en la interpretación de dos versiones de una obra (original y modificada) (Tanco et al., 2012). Por último, en el marco de un estudio con metodología mixta (sistema de captura de movimiento, registro audiovisual y entrevista) se realizaron entrevistas individuales que indagaban la experiencia fenomenológica en tríos de jazz, posteriormente a realizar performances en diferentes condiciones de interacción (en vivo y con un agente virtual) (Martínez et al., 2017; Pérez et al., 2017).

\subsection{Participantes}

La selección de los participantes de las entrevistas estuvo orientada a músicos con experiencia en performance solista mayor a los diez años, incluyendo la realización de performances en público. Los músicos seleccionados preparan o han preparado anteriormente obras instrumentales del repertorio académico occidental a partir de una partitura, contando con habilidades de lectura y técnicas para llevar a cabo dichas actividades. La selección no estableció ningún criterio de excelencia o validación dentro del ámbito académico; los músicos performers entrevistados en este estudio son valorados aquí no sólo por cumplir con sus capacidades interpretativas, 
sino por su dedicación y compromiso profesional, hacia su actividad y hacia el contexto social en donde la realizan.

La entrevista debía mantener ciertas condiciones que fueron comunicadas a los performers cuando se los invitó a participar del estudio. Los músicos debían estar disponibles y dispuestos a llevar a cabo la cantidad de entrevistas programadas, de modo que se pudiera garantizar la continuidad del estudio. Se seleccionaron aquellos músicos que pudieran concretar los encuentros de manera presencial, cara a cara, desistiendo de la participación de algunos músicos que se ofrecieron a responder por otros medios (escrito, telefónico, o videoconferencia). Los participantes además fueron advertidos acerca de que la entrevista sería grabada y transcripta para su análisis. Del mismo modo, se les comunicó que la entrevista sería anónima y sus nombres no serían publicados.

La convocatoria comenzó en el entorno cercano al investigador, y se extendió hacia otros que fueron sugeridos por investigadores colegas. A medida que se concretaban las entrevistas, los músicos participantes sugirieron algunos candidatos para el estudio (performers colegas), a la manera de lo que en la investigación cualitativa se denomina técnica de la bola de nieve (Taylor y Bogdan, 1984).

De acuerdo a las condiciones de la entrevista, sin embargo, también se contactaron a músicos que finalmente no participaron del estudio. Algunos estaban interesados en participar pero finalmente no se pudieron concretar los encuentros, o no podían cumplir con los tiempos de la entrevista. En otros casos, estaban dispuestos a participar de la conversación pero no acordaban con que ésta fuera grabada, aún sabiendo que era anónima. Algunos músicos que participaron, en cambio, manifestaron su voluntad de aparecer con sus datos completos, aunque finalmente se decidió mantener las condiciones iniciales del anonimato para todos ellos.

Una buena parte de los estudios cualitativos reside en la organización de la participación de las personas, nosotros mencionamos aquí el modo en que los pasos se fueron realizando para que pueda entenderse también que cada músico decidió participar o no hacerlo. Se debe mencionar también que algunos músicos no ven con buenos ojos la investigación en música, a veces por el desconocimiento de la disciplina, otras por el desconocimiento del investigador; aún en el caso de las investigaciones que se desarrollan con métodos más humanistas, pueden manifestar incomodidades. Los que finalmente participan, depositan su confianza en el investigador; además de un compromiso del entrevistador con el entrevistado, esto también implica un compromiso del entrevistado con el entrevistador. ${ }^{62}$ En general, hemos tenido buena disposición de los músicos que fueron convocados pero, mientras

${ }^{62}$ Es por esto que agradecemos a todos los músicos que han participado en este estudio. 
que algunos prefirieron finalmente no realizar la entrevista, algunos otros requirieron más información y tiempo hasta que finalmente confirmaron su participación. ${ }^{63}$

La tercera entrevista requirió volver a plantear los criterios de selección de los performers. Las temáticas en el diseño del guión requerían que los músicos pudieran hablar acerca de la preparación y realización de varias performances sobre una misma obra durante un período mayor a un año; además debían estar en actividad al momento del estudio, y que el período entre la última presentación y la entrevista no fuera mayor a un año.

\subsection{Procedimiento}

Una vez concertadas las entrevistas, las mismas se llevaron a cabo de manera presencial, cara a cara con el investigador. Los músicos conocían de antemano las condiciones generales de la entrevista: su duración, su registro (grabación) y el anonimato de las respuestas. Del mismo modo, sabían que participarían de una charla informal acerca de su actividad como músicos, la que abordaría cuestiones vinculadas a la preparación e interpretación de una obra a partir de una partitura, con preguntas acerca de su experiencia personal.

Al llegar a la entrevista se introdujo en la charla al entrevistado con una presentación del entrevistador. Si el músico no había sido informado en detalle sobre la entrevista se comenzaba anunciando brevemente la dinámica, y se le comunicaba abiertamente el interés por conocer su actividad. Del mismo modo, se le decía que tenía la libertad para contestar o no contestar alguna pregunta si así lo consideraba, y que en cualquier momento podía interrumpir la entrevista si no se sentía cómodo. Al ser advertido de que no habrían respuestas incorrectas, se le animó a contestar de acuerdo a su pensamiento, sin importar si era correcto o no; se le dijo que la entrevista no pretendía evaluarlo o juzgarlo como músico, que no debía intentar demostrar su conocimiento sino dar a conocer sus opiniones y pensamientos genuinos.

Las entrevistas se condujeron a partir del guión diseñado previamente. El mismo presentaba una forma secuenciada de preguntas que podía servir al entrevistador para ir introduciendo las temáticas, de acuerdo a un cierto orden lógico que mantuviera el curso de la charla y no sorprendiera al entrevistado. Si bien las temáticas a abordar fueron dispuestas a lo largo de la entrevista para garantizar el paso por todas ellas, en la práctica musical se manifiestan de manera interrelacionada. En la conducción de la entrevista, por lo tanto, las preguntas funcionan como disparadores o catalizadores del flujo de la conversación, y permiten ir abordando a la

63 Decidimos compartir estos detalles de la preparación de la entrevista porque pueden ser útiles para aquellos que están pensando en realizar una investigación similar. 
performance desde diferentes aspectos. Los caminos a seguir en la entrevista fueron variados, y las preguntas no respondidas fueron introducidas en el transcurso de la charla. Sin embargo, se respetó el tiempo acordado para la extensión de la entrevista, por lo tanto en algunos casos quedaron preguntas sin formular.

En todo momento se trató de crear un buen clima entre el entrevistador y el entrevistado, así como de mantener la fluidez de la conversación. Las preguntas seguían al guión pero no eran formuladas de un modo exacto: se enunciaron de manera particular para cada entrevistado, adoptando su lenguaje y su modo de hablar. Si el entrevistador percibía alguna incomodidad, se pasaba a otra pregunta u otro tema sin insistir. Como mencionamos antes, se evitó ahondar en cuestiones de autoexigencia del músico o en situaciones incómodas experimentadas por los músicos, explicándoles que la entrevista no se proponía abordarlas. A menudo, el entrevistador re-formulaba la pregunta cuando ésta no era comprendida por el entrevistado, así como también invitaba a desarrollar más si consideraba que la respuesta no era suficiente o percibía que el músico tenía más para decir, mostrando interés en conocer más acerca de lo que se respondía. Se priorizaron los temas en los que los entrevistados se sentían más a gusto y se mostraban más entusiasmados en sus respuestas; por lo tanto, según el caso, algunas respuestas fueron más concisas y otras más desarrolladas.

\subsection{Análisis de los datos}

El análisis de los datos se realizó siguiendo una serie de fases analíticas que, se consideran, son comunes a diferentes corrientes metodológicas del análisis de la entrevista. Nosotros presentamos aquí los lineamientos principales que luego serán abordados con un tratamiento particular de acuerdo a la información obtenida en cada una de las tres entrevistas realizadas.

El análisis de los datos en las entrevistas cualitativas está informado teóricamente, guiado por los supuestos teóricos del proyecto de la investigación, y de algún modo determinado por las preguntas derivadas de dichos supuestos. Se considera que el análisis de los datos comienza en el proceso de hacer preguntas a los entrevistados e interpretar sus respuestas. A partir de allí, se reconocen tres fases analíticas en el análisis de las entrevistas cualitativas: (i) reducción de datos; (ii) reorganización de los datos; y (iii) representación de los datos (Roulston, 2014).

Las estrategias analíticas siguen con la codificación de pasajes de la entrevista en un proceso de intercambio entre la información obtenida y el conocimiento teórico previo. Se comienza por las pre-suposiciones y luego éstas son cuestionadas, refinadas, o alteradas en etapas sucesivas. Schmidt plantea una estrategia analítica 
para la codificación en cinco etapas: (i) en respuesta al material, se establecen las categorías para el análisis; (ii) las categorías son reunidas en una guía analítica que es puesta a prueba y revisada; (iii) se codifican todas las entrevistas utilizando la guía de codificación; (iv) sobre la base de la codificación se pueden producir resúmenes de casos; $(v)$ se pueden seleccionar casos individuales para un análisis en profundidad (Schmidt, 2004).

A continuación presentaremos un detalle de los pasos a seguir en el análisis de las entrevistas de esta tesis.

\subsubsection{Preparación de los datos}

El proceso de análisis comienza con la preparación de los datos, que adquieren su materialidad final en las transcripciones de las grabaciones de las entrevistas. De todos modos, una parte importante de la información depende de la formulación clara y directa en las declaraciones de los entrevistados, la cual es indagada por el entrevistador. Es por esto que en la conducción de las entrevistas se incentiva al entrevistado a que vuelva a formular algunas expresiones o desarrolle más sus descripciones.

La transcripción de las entrevistas se llevó a cabo posteriormente a su realización. Con el objetivo de recuperar la mayor cantidad de información relevante posible, las entrevistas no se transcribieron una vez finalizada la realización de todas las entrevistas, sino que cada tarea de transcripción comenzó en un tiempo lo más cercano posible a su finalización. Antes de comenzar la transcripción, cada entrevista fue reproducida y escuchada por el investigador, para recuperar aspectos relevantes de la situación y familiarizarse con el lenguaje y el modo de expresión de cada entrevistado.

El contenido de las entrevistas fue transcripto de manera completa y literal por el mismo entrevistador. Además, se incluyeron informaciones añadidas entre paréntesis a los textos: características de la interacción (interrupciones, superposiciones, detenciones) o la entonación, como el carácter (serio, jocoso, irónico, susurrado, exclamaciones, etc.) que da sentido a las frases, onomatopeyas y risas tanto del entrevistador como del entrevistado. La precisión de la información por lo tanto debió dar cuenta también de situaciones ocurridas que no eran posibles de ser registradas en la grabación, como gestos, acciones (mirar hacia algún lado) o frases que se completaban con gestos (en lugar de palabras).

El poco tiempo transcurrido entre la entrevista y su transcripción facilitó recordar estos detalles importantes, sobre todo para la consideración de la información en la siguiente etapa. El contenido de estas entrevistas incluyó además situaciones 
como frases sin completar, que sin embargo contenían un sentido para el entrevistado y el entrevistador aunque las palabras no fueran pronunciadas (ej: frases que comienzan y se detienen en un verbo con un tipo de entonación particular). Estos detalles se registraron como comentarios añadidos al texto. ${ }^{64}$ Además, durante el proceso de transcripción se anotaron otros comentarios del investigador, según fueran surgiendo ideas o reflexiones acerca de las palabras de los músicos.

Las transcripción de los textos se realizó en un Software para el análisis de datos cualitativos (CAQDAS) Nvivo 11 (QSR International), y comprendió un total de 11 horas y 44 minutos correspondientes a 26 entrevistas realizadas. El formato final de las entrevistas se organizó en documentos separados que fueron nomenclados por número de entrevista (1, 2 y 3 ) y por Caso (músico entrevistado).

\subsubsection{Reducción de los datos}

A partir de la lectura reiterada de las entrevistas, se realizó una primera organización del material. En esta etapa, se seleccionan fragmentos de la entrevista (párrafos y diálogos) que contienen información relevante con respecto a las metas, las preguntas y el marco metodológico de referencia de la investigación. De esta manera, se distinguen pasajes de la conversación que no se consideran relevantes o no abordan el tema de estudio, así como también momentos en donde la charla se desvía hacia otros aspectos o temas de la práctica musical y la vida personal de los músicos.

Durante el proceso de selección, estos fragmentos son señalados y codificados de un modo abierto en el software de análisis para obtener información acerca de las temáticas o sub-temáticas que permiten relacionar la información entre los músicos. La modalidad abierta de codificación pretende no categorizar en base a los pre-conceptos de la reflexión sobre el tema y, en cambio, organizar la gran cantidad de material en base a similitudes temáticas identificadas.

A partir de esta primera selección, se compara la cantidad de fragmentos y sujetos (casos) para cada temática, y se seleccionan aquellos que puedan permitir un inter-juego entre las descripciones de los entrevistados. La lectura orientada por los temas iniciales permite observar aspectos individuales que puedan relacionarse con las preguntas de la investigación. El contenido verbal es evaluado para considerar si los entrevistados toman o no los significados de los términos propuestos en las

\footnotetext{
${ }^{64}$ En este estudio, elegimos no registrar las entrevistas en video para no introducir un elemento que pudiera inhibir a los músicos. Esta decisión a su vez fue tomada para que los músicos participaran de la investigación, ante las inquietudes que nos plantearon acerca de las condiciones de la entrevista.
} 
preguntas, el significado que les otorgan, con cuáles otros términos se completan o vinculan, etc.

Durante este proceso se realizan anotaciones sobre reflexiones y posibles códigos o categorías de análisis, para ir vinculando el análisis con las respuestas de la entrevista a lo largo de todas las temáticas, e identificar conexiones entre ellas. En nuestro estudio, la selección de los fragmentos se vincula con la posibilidad de obtener descripciones de los entrevistados dejando de lado, en la mayoría de los casos, las respuestas breves (sí, no, no sé); sin embargo, algunas de éstas son consideradas para mostrar casos contrarios (rechazo o negación a lo propuesto en las preguntas).

$\mathrm{Si}$ bien en una investigación cualitativa las descripciones representan el contenido esencial de la información, en las etapas sucesivas la reducción de la información produce una síntesis analítica que se aleja de las expresiones originales. Hemos seleccionado, para cada una de las entrevistas de este estudio, un grupo de descripciones que consideramos que representan el punto de vista individual de cada uno de los músicos, y representan para nosotros la información más relevante.

Para que puedan apreciarse, en esta tesis recopilamos y presentamos la selección de los pasajes de las entrevistas en un apéndice para cada capítulo. Allí pueden encontrarse las unidades temáticas con las propias palabras y expresiones de los músicos, en algunos casos con algún tipo de organización interna en sub-temáticas o consideraciones analíticas preliminares. Para la comprensión de los pasos sucesivos en el proceso de análisis de los datos, sugerimos a los lectores comenzar por los apéndices de cada entrevista antes de leer los resultados.

\subsubsection{Preparación de la guía analítica}

Las temáticas, sub-temáticas y los aspectos individuales son considerados en relación a los conceptos teóricos y empíricos existentes. Las categorías son evaluadas en el contraste con los aspectos individuales de las respuestas de cada músico en las entrevistas. Estas categorías pueden ser consideradas y desarrolladas en términos y combinaciones de términos, de acuerdo a las preguntas formuladas y las descripciones obtenidas en relación a las preguntas de la investigación.

Las categorías analíticas se constituyen en un borrador de la guía de análisis, la cual es revisada y evaluada. Los pasajes se relacionan con las categorías analíticas en varias entrevistas, o un grupo de entrevistas seleccionadas. Las categorías se describen a través de nodos y sub-nodos, así como también se consideran las vinculaciones entre éstos, para distinguir y relacionar los datos en la evaluación de la guía que finalmente es utilizada para la codificación. Durante este proceso, las categorías pueden ser afirmadas, reformuladas o descartadas según la capacidad 
para organizar y entender la información. En nuestro caso, hemos tenido la posibilidad de discutirlas con investigadores colegas en el marco de nuestro equipo de investigación. ${ }^{65}$

\subsubsection{Codificación de las entrevistas}

Durante la etapa de la codificación del material, cada entrevista se evalúa y clasifica de acuerdo con las categorías de la guía analítica establecidas en la etapa anterior. Debido a las características del presente estudio, algunas especificaciones deben realizarse con respecto al tratamiento y la consideración de la información obtenida. Las entrevistas fueron realizadas a músicos profesionales con estudios formales, aunque de diferentes edades y contextos de estudios (en diferentes épocas e instituciones). Consideramos que todos ellos tienen la capacidad de expresar y definir de manera clara el contenido de sus respuestas, y por eso muchas veces nos servimos de las palabras originales en la codificación. Además, los entrevistados comparten con el entrevistador un lenguaje común de uso en la práctica musical que, eventualmente, puede ser indagado y explicitado en la interacción durante la charla. Debido a estas particularidades, el establecimiento de los códigos muchas veces se corresponde con los enunciados y con los términos específicos (en su forma literal) utilizados por los músicos. Ante la duda o indefinición, preferimos mostrar en nuestro análisis un detalle de los términos que consideramos dentro de una misma categoría (nodos y sub-nodos de la codificación) en lugar de realizar una reducción directa, para que puedan seguirse los pasos que nos llevan al establecimiento de cada una.

En el análisis también tenemos en cuenta los usos metafóricos del lenguaje que los músicos incorporan en sus descripciones. El uso de metáforas en la descripción de la música forma parte de la práctica de enseñanza y el desempeño profesional de los músicos; este tipo de uso del lenguaje puede encontrarse tanto en la teoría de la música como en la estética de la música (Scruton, 1999). Estudios realizados muestran la incidencia de los esquemas imaginísticos básicos en la experiencia de la música a través de proyecciones metafóricas entre el domino de la experiencia sensorio-motora y el dominio de la cognición musical (Martínez, 2008a, 2008b). En investigaciones que hemos realizado, (i) indagamos en la relación entre música y pintura en los préstamos mutuos de términos (Tanco, 2013a), y (ii) analizamos el lenguaje metafórico que los músicos utilizan para describir su

\footnotetext{
${ }^{65}$ Equipo de investigación B298 "La Corporeidad de la Mente Musical. Hacia una definición de su estatus en el estudio de la Ontogénesis, la Percepción y la Performance de la Música" del Laboratorio para el Estudio de la Experiencia Musical (LEEM) de la Facultad de Bellas Artes, Universidad Nacional de La Plata. Directora: Dra. Isabel Cecilia Martínez
} 
experiencia personal cuando están haciendo música (Martínez et al., 2017; Pérez et al., 2017; Tanco et al., 2012).

Durante la entrevista, los términos y concepciones de los músicos pueden distribuirse en las respuestas o utilizarse persistentemente durante toda la entrevista. Para dar cuenta de la relevancia de las categorías analizadas, realizamos una distinción entre el número de apariciones en el total de las entrevistas (frecuencia) y el número de casos (músicos) en donde se presentan. De este modo, pretendemos evitar la reducción de las apariciones, en pos de considerar su importancia y aplicación a lo largo de un conjunto diverso de fragmentos (referidos a diferentes temáticas del estudio), al mismo tiempo que se evita generalizar la frecuencia al total de los músicos.

Hemos considerado la posibilidad de asignar más de un nodo o categoría en una misma unidad de análisis. Esto ocurre en varios fragmentos de las entrevistas, y nos permite entender cómo se presentan relaciones que las unen, vinculan o separan.

\subsubsection{Presentación de la codificación}

El proceso de análisis de las entrevistas finaliza con la obtención de datos que incluyen categorías y códigos (nodos y sub-nodos). Para poder identificar aspectos que permitan realizar una comparación entre los casos, se consideran las tendencias dominantes de los nodos, sub-nodos y categorías. Estas tendencias se evalúan por medio de datos cuantitativos que dan cuenta de la cantidad de codificaciones para un mismo código, llamados frecuencias. En este estudio consideramos la frecuencia de cada código en el total de las entrevistas y en el número de casos (performers), para poder apreciar las tendencias en el total de los músicos entrevistados. El establecimiento de códigos o nodos como categorías o términos descriptores produce la reducción de la información y una pérdida del detalle de la descripción, pero permite la síntesis y definición de los resultados en relación a las preguntas formuladas.

En la presentación de la codificación, los datos se organizan en tablas donde se presentan las frecuencias en nodos, sub-nodos (elementos particulares de los nodos) y categorías que los vinculan o contienen. A través de las indicaciones de frecuencia se obtiene una visión general de las distribuciones dentro del material, proporcionando información sobre la base de datos.

En este estudio, las frecuencias de los nodos son presentadas en números dispuestos en columnas o filas. Para distinguir entre la cantidad de nodos y la frecuencia en los casos, los datos se presentan en columnas o filas separadas. 


\subsubsection{Presentación e interpretación de los datos}

Al presentar los resultados, volvemos a las palabras de los músicos a la luz del análisis de las categorías y códigos (nodos y sub-nodos) realizado. Estas categorías nos permiten interpretar la codificación en el contexto de la información obtenida de primera mano. Por cuestiones de redacción y lectura, evitaremos la utilización del término interpretación para referirnos a nuestras consideraciones de los datos, y de este modo evitar confusiones con la interpretación musical que realizan los performers.

La presentación de los datos es mediada por los criterios de consideración de las tendencias dominantes en las frecuencias de la codificación antes mencionados. Sin embargo, también resulta relevante el poder descriptivo de una categoría para dar cuenta de respuestas a las preguntas de la investigación. Desde un punto de vista técnico, Schmidt (2004) sugiere la presentación de los resultados en forma de tablas. El resumen de los datos en las tablas permite caracterizar, organizar o eventualmente comparar de manera clara las interpretaciones de los pasajes de la entrevista. 


\section{ENTREVISTA 1}

\section{Objetivos}

Describir a la performance musical en un contexto de relaciones sociales que el músico establece con otras personas involucradas de manera directa o indirecta. Para esto, nos proponemos obtener información que defina a las relaciones en términos de autonomía, agencia, intencionalidad e intersubjetividad que supone la construcción de significados en la interacción social.

\section{Metodología}

\subsection{Participantes}

11 músicos instrumentistas ( 9 pianistas, 2 guitarristas; 7 mujeres, 4 hombres; edad promedio $=54$ años; desviación estándar= 14.16) con experiencia en la realización de performance solista (promedio $=24$ años) participaron voluntariamente del estudio.

\subsection{Aparatos}

Las entrevistas fueron registradas en audio digital con un grabador de mano Zoom H4. Las transcripciones y análisis de los datos fueron realizadas con un Software para el análisis de datos cualitativos (CAQDAS) Nvivo 11 (QSR International).

\subsection{Procedimiento}

Los encuentros fueron realizados de manera presencial, cara a cara con el investigador. Cada entrevista tuvo una duración promedio de 36 minutos, habiéndose registrado un total de 6 horas y 36 minutos (6hs. 30ms.). Las entrevistas se llevaron a cabo en un contexto de conversación entre músicos, donde el entrevistador fue presentando temas en forma de preguntas a partir de un guión prediseñado.

\subsection{Guión de la entrevista}

Se diseñó un guión para la conducción de la entrevista (Ver Apéndice 1). La charla se iniciaba con una pregunta acerca de las primeras experiencias de 
aprendizaje, en donde se esperaba que el músico relatara e introdujera al investigador en su contexto personal y su uso particular del lenguaje. El guión continuaba con preguntas orientadas a la experiencia del músico en la performance y sus concepciones en relación al compositor, al público, a otras interpretaciones de la obra y a otras personas que pudieran incidir en su preparación de las obras. A lo largo del guión, estas situaciones fueron indagadas en relación a la multiplicidad de posibles intenciones que guían las acciones del músico en el momento de tocar el instrumento.

\subsection{Análisis de los datos}

Se seleccionaron 129 fragmentos de la entrevista que presentaban descripciones de las relaciones que los performers establecían con otras personas, roles o entidades con las que ellos se involucraban en su actividad musical. Algunas personas o roles estuvieron determinados de antemano en la formulación de las preguntas (por ejemplo, el compositor y el público). En otros casos, las preguntas fueron indeterminadas o abiertas con el fin de indagar acerca de otras personas, roles o entidades, con el fin de conocer más sobre los vínculos sociales públicos o privados relativos a la práctica musical de los participantes. A partir de la lectura reiterada de las entrevistas, también se pudo observar que los músicos se referían a relaciones que establecían con la partitura y con la obra (que no son personas). Teniendo en cuenta este tipo de personificaciones ${ }^{66}$, las mismas se incorporaron al conjunto de temáticas iniciales.

El criterio de selección aplicado intentó en un principio organizar el material distinguiendo entre personas, objetos o entidades en relación a las cuales los músicos presentaban descripciones de relaciones o interacciones. En el Apéndice 1 pueden encontrarse los fragmentos seleccionados, agrupados en las siguientes temáticas: (i) ¿para quién toca el performer?; (ii) obra musical; (iii) texto musical; (iv) compositor; (v) otras interpretaciones; (vi) otras personas; (vii) uno mismo; (vii) público; y (ix) presencias.

\footnotetext{
${ }^{66}$ Lakoff y Johnson (1980) se refieren a las personificaciones como metáforas ontológicas (metáforas de sustancia y entidad). Según los autores, "Esto nos permite comprender una amplia diversidad de experiencias con entidades no humanas en términos de motivaciones, características y actividades humanas." (p. 71) "...que nos permiten dar sentido a fenómenos del mundo en términos humanos -términos que podemos entender sobre la base de nuestras propias motivaciones, objetivos, acciones y características." (p. 72)
} 
Tabla 1. Frecuencias y Casos de los dos aspectos codificados en las descripciones de los músicos (en las filas, los tipos de relación; en las columnas las personas o entidades en relación a los performers. Algunos nodos que se presentan en la mayoría de los Casos (performers) son destacados en negrita.

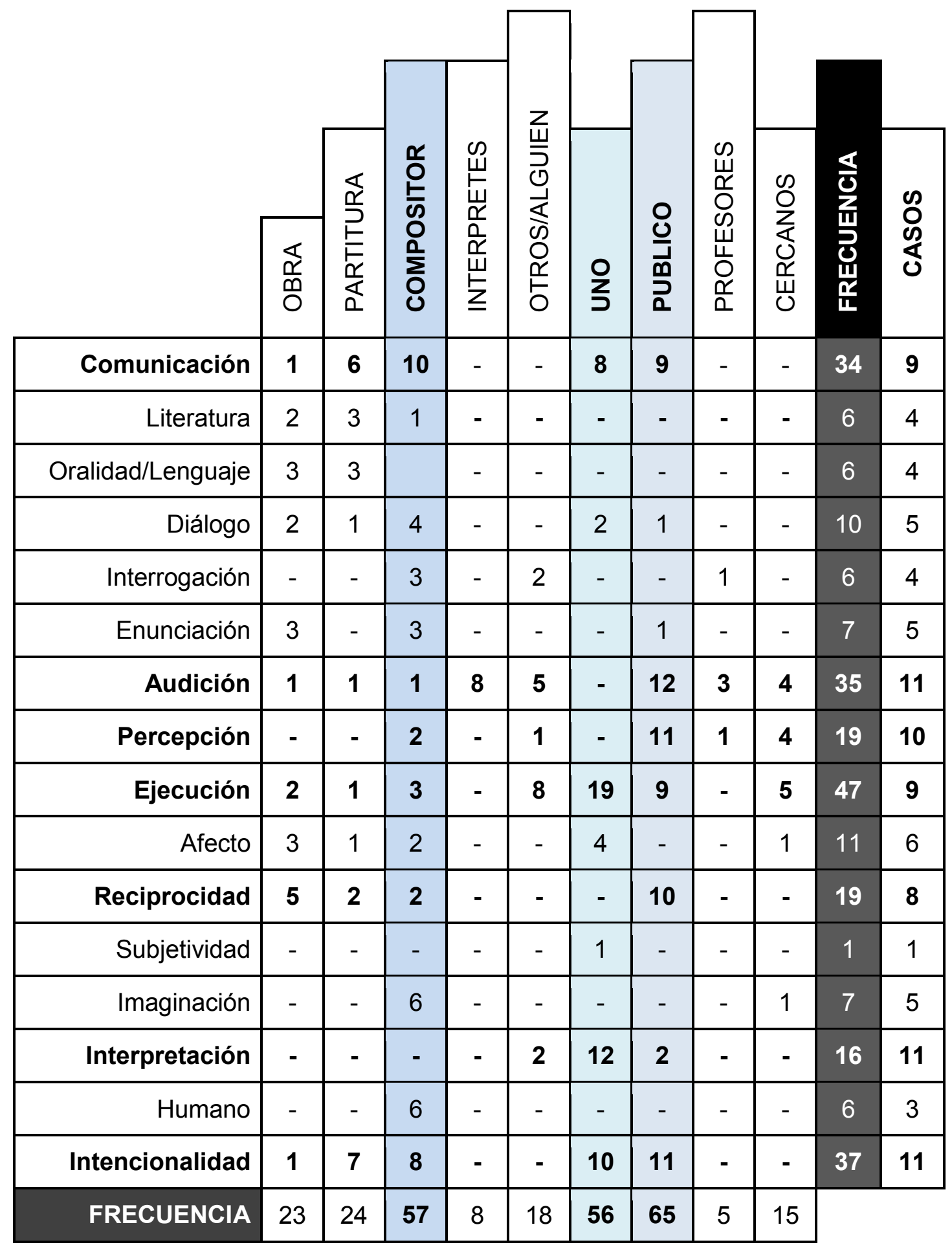

La guía para la codificación fue pensada para dar cuenta de dos aspectos en las descripciones de los músicos: el primer aspecto se refiere a quién o qué establece una relación con el músico, e identifica personas o entidades (por ejemplo: compositor, 
público, obra, etc.); el segundo se refiere a cómo se vinculan las personas o entidades, y el tipo de relación que se establece (por ejemplo: intencionalidad, comunicación, percepción, etc.).

En la Tabla 1 se presentan los nodos codificados en un cuadro de doble entrada, para permitir visualizar la interrelación entre los dos aspectos. Los nodos correspondientes a quién o qué se distribuyen en las columnas, y se entrecruzan con las filas que incluyen los nodos que caracterizan el cómo se vinculan.

Con respecto al cómo, es necesario considerar que algunas preguntas de la entrevista introducían los términos que finalmente fueron codificados. Por ejemplo, ¿te parece que hay una comunicación? puede inducir al entrevistado a referirse a una relación utilizando la misma palabra en la respuesta. En esos casos, codificamos únicamente aquellas respuestas afirmativas, entendiendo que los performers aceptaban los términos como descriptores de la relación. Algunos de estos nodos son: comunicación, intencionalidad, ejecución, e interpretación, que fueron los que presentaron mayor frecuencia. Por otro lado, se codificaron otros nodos que surgen espontáneamente en las descripciones de los performers de un modo no-inducido: audición, percepción, reciprocidad y diálogo.

Para entender las frecuencias de una codificación se debe considerar el total obtenido y también la frecuencia particular con cada persona o entidad. Por ejemplo, Comunicaciónpresenta una frecuencia de 39 nodos, 10 de los cuales se corresponden con el Compositor, 8 con Uno mismo y 9 con el Público, 6 con la Partitura y 1 con la Obra. Además de la frecuencia en la totalidad de las entrevistas, puede visualizarse en la última columna de la derecha la cantidad de músicos que utilizaron a Comunicación como un descriptor de los vínculos; de esta manera los datos cuantitativos pueden también ser considerados como una tendencia en el grupo de performers.

\section{Resultados}

\section{1 de la información codificada}

A continuación presentamos algunos fragmentos de la entrevista para dar cuenta de los nodos y las relaciones vistas en el apartado anterior entre la distribución horizontal y vertical de la Tabla 1.

En primer lugar, hemos realizado consideraciones hacia un conjunto de relaciones que son descriptas en diferentes direcciones. Estas observaciones tienen en cuenta el punto de vista del músico en su experiencia, sus percepciones y sus concepciones acerca de la práctica; por lo tanto nos enfocamos en sus descripciones para conocer cuáles son las relaciones que guían su actividad, según las palabras de 
cada uno de ellos. Con respecto al cómo, consideramos que los performers se involucran en relaciones que se establecen en varias direcciones: (i) desde él, (ii) hacia él, (iii) consigo mismo o (iv) recíproca. A continuación presentamos ejemplificaciones para cada una de ellas.

\section{La comunicación desde el músico}

Desde el músico al compositor:

Ejemplo 1

I - ¿Uno se comunica con el compositor?

M - Sí, yo creo que sí, uno siempre se comunica con el comp... Si el compositor se quiere comunicar con uno no sé, pero uno con el compositor sí.

En esta breve respuesta el performer distingue entre una interacción real y una virtual, y expresa su intencionalidad de establecer un vínculo con el compositor.

\section{Ejemplo 2}

I - ¿Y tenés en cuenta intenciones del compositor?

M - Sí, todo el tiempo.

$\mathrm{I}$ - ¿Y cómo las encontrás?

M - No sé, en los detalles uno intenta acercarse a la intencionalidad del otro, del que estuvo del otro lado, por eso te digo hay alguien que se esforzó mucho en poner lo que está escrito, como pudo. Cuando digo 'como pudo' es porque el código es hasta ahí. Digamos.

Aquí se distinguen dos lados, del otro lado del texto hay alguien. La intencionalidad del compositor es descripta en términos de espacio, la intencionalidad del performer es descripta como una acción dirigida en el espacio hacia el otro.

Desde el músico a la obra:

I - ¿Y qué hay que hacer para entender la obra?

M - Comunicarse con la obra. Sentirla, sentir que te gusta, que querés decir algo. Tener una intención de comunicar algo.

En este caso, entender la obra es sentir la obra. Entenderla se logra a través de una interacción y una intencionalidad comunicativa con respecto a la obra.

Desde el músico al público:

I - ¿Hay una comunicación entre vos y el público?

M - Sí, por lo menos yo la planteo, no sé si ellos se comunican conmigo, pero yo con ellos seguro.

Esta performer propone al público una interacción a través de su intencionalidad de comunicarse con ellos. 


\section{La comunicación hacia el músico}

Desde la obra al músico:

I - ¿Te parece que el compositor se comunica de alguna manera con el intérprete o con vos?

M - (silencio, piensa) Termina habiendo, supongo, algún tipo de comunicación. Hay a veces una cuestión como de conexión, por lo menos sí, uno dice... yo agarro algo de Bach, a mí me gusta, y yo siento como que "uh, qué groso esto!", me llega. Siento como que... como que uno se vincula afectivamente ¿no?, de alguna manera... como que llega, que le llega la música que el tipo compuso, te está llegando y uno como que se vincula.

El vínculo con la obra es descripto en términos afectivos. Es desde la obra al performer porque es descripta en términos de espacio: llega hacia el músico. A partir de allí, la conexión se establece con el compositor.

Desde el compositor al músico:

M - El tipo te tira un "usá el pedal como si fuera un baño", como que te estés bañando las notas con pedal. Eso está buenísimo! Te abre una imagen sonora directamente.

I - ¿Lo pensás como una comunicación?

M - Sí, porque el tipo te está diciendo cómo quiere que suene ese pedal, no es cualquier pedal. Es como si estuvieras bañando las notas, está buenísimo.

La intención del compositor es enunciada en la partitura como "doucement baigné de pédale ${ }^{67}$. El verbo baigné es participio (la forma no personal del verbo que este toma para funcionar como adjetivo sin perder del todo su naturaleza verbal), el verbo imperativo sería baigne-toi. El adjetivo es entendido como un verbo dirigido al músico. La intencionalidad del compositor es interpretada como una sugerencia: "invita" (no ordena) a la performer a interpretar de alguna manera, y la performer lo toma.

Desde el público al músico:

I - ¿Qué sentís que recibís vos?

M - Y, la atención, vos sentís que es una retroalimentación. Es como que trasciende el silencio, esa atención.

Eso es como una comunicación porque eso a su vez hace que vos te involucres más, que te explayes o que te sueltes más. Vas sintiendo esa cosa.

El silencio es la atención, la atención es una respuesta del público que percibe acerca de lo que está produciendo cuando toca. Es algo que vuelve a partir de lo que el músico produce.

Desde la profesora al músico:

M - Pero de mi profesora me acuerdo siempre muchísimo que a ella le gustaba mucho cantar "da da da da" (canta). Y había toda una expresividad en los sonidos que hoy

${ }^{67}$ Esto podría ser traducido como "suavemente bañando el pedal" 
mismo tengo muy presente, todo eso inserto en todas otras búsquedas, por supuesto. Pero por momentos me acuerdo, al estar estudiando una obra, qué sé yo, "uh, esto mi profesora lo haría de tal manera" "acá, mirá qué bueno lo que me dice ella" ¿no?

La intención del músico se constituye como algo buscado y se produce a partir de identificar una conexión con la actividad interpretativa de una persona conocida. Implica imaginar a la persona tocando: es una imagen dinámica del sonido (la expresividad) y del movimiento para producir el sonido (imaginar a la persona en acción). Esto le sirve al músico para interpretar como si fuera su profesora.

\section{La comunicación desde el músico hacia el músico}

\section{Ejemplo 1}

I - ¿Cómo es tocar para uno?

M - Es esto que te contaba antes tal vez, de satisfacerse intelectual, emocional y físicamente. Si las tres se te dan, alguna vez, sos muy feliz. Y si sos muy feliz, ese es el objetivo a lograr.

I - ¿Hay una comunicación con uno mismo?

M - Sí. No sé cómo es no-comunicarse con uno mismo.

Esta sensación positiva de satisfacción es integral, abarca todos los aspectos de la cognición humana: cerebral (intelectual), corporeizada (físicamente) y afectiva (emocional). La comunicación es sentida como una acción donde el performer es emisor y destinatario e implica una correspondencia implícita.

\section{Ejemplo 2}

I - ¿Uno se puede comunicar con uno mismo?

M - Sí, yo creo que sí. Porque el sonido te vuelve, vos lo producís, te vuelve. Es una maraña, sí. Te vas escuch... si no te escuchás, qué estás produciendo? Es... yo creo que hasta digamos ni siquiera hay una división, va y viene todo el tiempo. Circular, completamente.

Aquí lo circular da cuenta de una comunicación más allá del sentido dirigido del performer al performer mismo. Aunque podemos considerarlo en los mismos términos que en el párrafo anterior (Ejemplo 1), la descripción no produce una distinción entre los tres aspectos de la cognición, sino como una fenomenología de algo indivisible.

\section{La comunicación a través de un diálogo}

1) Diálogo con la obra:

M - El problema es cuando vos trabajás, analizás, convivís con la obra. Esa convivencia para mí implica una relación dialógica con la obra. En esa relación hay un proceso de maduración hasta que llegues a comprender, a entender que los procesos de frase que vos querés hacer tienen que ser de tal o cuál manera. 


\section{2) Diálogo con la partitura}

M - Lo primero que hago es decodificar. Así, jtac! A secas. Y después, a medida que la vas tocando, como que es un diálogo contínuo con la partitura. Como que vas descubriendo cosas, la música te devuelve otras cosas, y así, qué sé yo. No sé.

I - ¿Y cómo sería ese diálogo?

M - Es como que todo el tiempo se va actualizando la música en vos. No es lo mismo tocar una cosa después de un mes que el primer día que la empezaste a tocar. Como que ya vas a niveles más macro, digamos, de lo que suena. No estás tan pendiente de por ahí "ay, esta parte no me sale" o "éste dedo". Como que ya fluye y bueno vos ya te vas como preguntando otras cosas.

En estos dos párrafos la relación se establece con entidades no humanas. En ambos casos lo que es descripto por los performers implica una relación dinámica (que evoluciona en el tiempo) como una maduración o actualización. Al entender o descubrir a través de ésta vinculación, consideramos que el performer construye el significado de la obra o partitura interactuando con un agente virtual.

\section{3) Diálogo con el compositor:}

M - Mirá, en una cuestión muy personal, yo a veces siento que dialogo con Beethoven, cuando estoy tocando sus sonatas... No es ninguna cosa misteriosa, simplemente... en el sentido de lo que me pasa con una obra musical que veo un ser humano atrás, que compuso eso. Qué sé yo, el 15 de Mayo de 1797 Beethoven estaba en el compás 15 de la sonata pastoral. El tipo está haciendo eso, ¿entendés? Es algún ser humano que hace eso.

(...)

El asunto es que, en realidad, en ésta relación dialógica que te comentaba recién, yo encuentro un ser humano ahí atrás. Un ser humano que está diciendo cosas, que sufre o que está alegre, o tiene una nobleza extraordinaria en lo que está planteando, que genera expectativas, que habla sobre el tiempo y el espacio. En ese sentido me parece comprender realmente qué es lo que... (el entrevistado no lo completa y retoma) en éste diálogo con el compositor.

Aquí el diálogo implica una relación con una persona que, aunque haya existido, el performer sólo "conoce" a partir de sus obras. Esta interacción virtual, imaginada o inferida, es posible debido a la intencionalidad del músico que puede o quiere interpretar en el texto intencionalidades atribuídas a una entidad humana.

\section{4) Diálogo con uno mismo:}

I - ¿Cómo sería tocar para uno mismo?

M - Te sentás a tocar para vos, porque te gusta, porque querés escuchar eso, ésta obra que te gusta o la estudiaste.

I - ¿Hay una comunicación con uno mismo?

M - Sí. Podría haber un diálogo con uno mismo (pausa).

5) Diálogo con el público:

M - ...como que hay un diálogo.

I - ¿Existe una comunicación entonces? 
M - Sí, el emisor emite, estoy tocando. Pero el receptor por ejemplo, termina algo, empieza otra cosa, la gente aplaude, por ahí empieza a hablar un poquito... Yo de repente hago otra cosa de la que tenía pensada, empiezo asiiii que se yo, bajito y hay como una especie de comunicación. Si yo te estoy diciendo "callate la boca", ponele, bueno "arranqué, empecé a tocar" entonces estoy diciendo algo, la gente se calla, me presta atención, todo el público está así, y yo hago otra cosa, entonces es como un ida y vuelta en ese sentido. Ahí hay una comunicación digamos, clara. Pero en ese mismo nivel, con el resto de la música con la gente atenta.

En los párrafos 4 y 5 el diálogo descripto se establece con personas que podrían interactuar de manera real con el performer. En el primer caso, hay una reciprocidad entre lo que se quiere tocar y lo que se quiere escuchar; el performer puede dar cuenta de una comunicación porque lo que ocurre lo involucra en ambos casos. En el segundo caso, son diálogos no verbales (aunque implican al sonido) que son atribuídos a las acciones que el performer y el público realizan; cómo no existen palabras, este tipo de interacción es descripta de un modo análogo con una conversación.

\section{Relaciones recíprocas}

1) El respeto mutuo entre el compositor y el intérprete:

M - Y yo creo que nunca es nada más importante que la música, esto de la interpretación. Me parece que es como una cuestión como de respeto mutuo. Que el compositor tiene que darle la libertad al intérprete, tratar de orientarlo con las indicaciones si uno cree más claramente que esto tiene que ser más melancólico, o como sea, y el intérprete tratar de respetar, si le pusieron la palabra melancólico, esforzarse para que sea melancólico sería algo que está bien.

2) Entre el performer y la música:

M - Cuando la gente va a escuchar... Entonces yo no me puedo dar el lujo de decir "hoy no le pongo nada". Por más que hay días que estoy mal o no me siento físicamente, me voy acomodando. Yo le debo respeto a la gente. Yo termino entrando en la música, es recíproco. Yo la produzco, pero la música me atrapa, viste. No sé cómo explicarlo. Una vez que entró a sonar te metés en el lenguaje. Sino no se podría hacer.

Estos dos párrafos describen relaciones sociales reales o virtuales entre agentes: el compositor, el intérprete, el público y la música. En ambos casos, se describe un compromiso o respeto que podemos entender como acuerdos sociales entre personas involucradas en un fenómeno musical. En relación a la música como agente virtual (párrafo 2), la descripción es a través de acciones físicas y percepciones corporales recíprocas: uno entra en la música y la música lo atrapa.

3) Entre el performer y el público:

Ejemplo 1

I - ¿Pensás que hay una comunicación entre vos y los demás? 
M - Sí. Hay una comunicación, que va y que viene... pero esa obra que uno que está tocando el otro generalmente la conoce. Sabe qué va a pasar y lo está esperando. Y si no lo hacés, entonces le pasa algo. Hay algo que no te puedo traducir en palabras cómo es. No es una presunción, algo está pasando, es una certeza que uno tiene. Pero trasladarlo a la palabra ¿cómo fue? No se puede decir. Yo tengo esa confianza que está yendo y viniendo.

\section{Ejemplo 2}

I - ¿Sentís que recibís algo del público?

M - Sí, cuando recibis la atención, cuando se produce el silencio. Vos sabés que algo les está pasando parecido a lo que te pasa a vos. Cuando vos sentís que entregaste mucho entonces ahí hay mucha comunicación o comunión.

\section{Ejemplo 3}

I - ¿Qué diferencia encontrás?

M - Yo puedo tocar solo en mi casa y emocionarme, pero cuando hay público... Cuando hay gente escuchándote, yo también estoy escuchando al público, lo tengo presente... aunque yo no los mire, yo sé que están ahi, sé que respiran... Hay una cosa que es... ya te digo, no la puedo describir pero hay como un ida y vuelta... hoy en día se habla mucho de lo energético, yo.... No sé si es así. No lo sé, pero no es lo mismo tocar solo que con otro....

En estos tres ejemplos podemos entender que los performers perciben una interacción real y recíproca con el público. Aquí Percibir describe una relación intersubjetiva con el público, que puede ser escuchada en el silencio, como una certeza o una energía. Lo interactivo es descripto como algo que se produce en ambas direcciones (que viene y va), como una comunicación a partir de lo compartido (les ocurre algo parecido) o una presencia, un acompañamiento que se percibe aún en el silencio.

\section{La comunicación interrogativa (preguntas)}

Hacia el músico:

M - Por ejemplo, me pasaba con Chopin, como que me apabullaba porque sentía que eran preguntas y preguntas y preguntas sin respuesta.

I - ¿De dónde salían?

M - Salían de mí pero como que él escribía preguntas, frases que no tenían como respuestas, estas cosas más existenciales permanentemente. Me apabullaba eso. En realidad era como que me inhibía más de lo que me estimulaba.

Desde el músico:

I - ¿El compositor se comunica con el intérprete?

M - Sí, por supuesto. Yo a veces digo “¿para qué escribiste tal cosa?” (ríe) ¿y esto? ¿para qué pusiste esa nota ahí?

Estos dos párrafos describen situaciones no reales en donde se produce una comunicación a partir de preguntas. En ambos casos provienen del performer: en el primero las preguntas son desde el compositor al músico; en el segundo, el performer 
le realiza preguntas al compositor. En los dos consideramos que son intencionalidades del músico en formas de preguntas para lo que se convoca a un agente virtual con el propósito de "hacerse" entender cuestiones de la obra.

\section{El aporte de otros durante la preparación de la performance}

1) El músico puede recibir un aporte:

$\mathrm{I}-$ ¿Y te ha pasado que recibiste alguna opinión?

M - Sí, sí, te escuchan y te hacen algún comentario.... Y, uno siempre los escucha. Si es algo que del todo no entendés, yo siempre hago el esfuerzo de tratar de escuchar lo que te están diciendo.

2) El músico puede solicitar un aporte:

I - ¿Recibís ayuda de otros en tu preparación de la obra?

M - No, cuando ya la tengo más o menos pregunto. Pregunto o me gusta que la escuchen.

$\mathrm{I}-$ ¿Colegas o amigos?

M - Sí, sí. "Che mirá, escuchala, cómo va esto, o cómo...".

En la relación con otros agentes que intervienen en la preparación de la performance, también hemos encontrado que pueden ser comentarios hacia el performer, o que la iniciativa surja de éste para solicitar una ayuda.

\section{El aporte de otros durante la preparación de la performance}

En las preguntas de la entrevista, la intencionalidad en el performer fue indagada de manera directa en relación al compositor y de manera indirecta con respecto al público y a otros performers. A continuación se presenta el modo en que la información de las respuestas fue comprendida, y se entiende que la intencionalidad puede ser descripta de un modo diferente de acuerdo al vínculo que el performer establece con cada uno de ellos tres:

(i) Los músicos pueden inferir las intenciones del compositor cuando están preparando la obra -más allá de decidir cumplirlas-, y consideran a la partitura como el medio principal para acceder a ellas.

(ii) La intencionalidad del público no se infiere de manera directa. Considerando siempre el punto de vista del músico, interpretamos que éste tiene en cuenta las expectativas del público en su intencionalidad. Esta interpretación se basa en la relación entre intencionalidad y expectativa (Acero y Villanueva, 2012).

(iii) La intencionalidad de otro performer es más directa en el sentido que ambos realizan acciones similares en relación a una partitura. Esto comprende por lo tanto acciones concretas, corporales y sonoras que el 
músico puede corresponder con su interpretación o su performance de la obra.

(iv) Por último, en estas relaciones que el performer establece como atribuciones, expectativas o intepretaciones concretas de la obra entendemos que el performer construye una intencionalidad que considera como propia, a partir de intercambios de significados (reales o virtuales).

A continuación presentamos algunos fragmentos de cada una de ellas.

\section{(i) Intencionalidad del compositor}

Ejemplo 1

M - Yo no me coloco en un lugar así.... Yo construyo la obra con el que la hizo, eso es lo que para mí es atrapante.

I - ¿A qué te referís...?

M - Qué análisis yo hago de la obra, qué me imagino que el compositor quiso decir y qué es lo que yo quiero decir con esa obra. Elijo esa y no otra, ¿no? A esta altura uno elige lo que tiene ganas de tocar, cómo y de qué manera, ¿no?

\section{Ejemplo 2}

M - Por ahí el compositor me dice "acá hay varias partes que son diferentes", yo decido exagerarlas, o yo decido no exagerarlas, no sé. Como que el compositor te dice algo a través del papel pero después...

En estos ejemplos el performer considera la intencionalidad del compositor en relación a sí mismo. En el primero, la intencionalidad es descripta como una enunciación (decir) a través de la obra que surge en el análisis del performer. En el segundo, la enunciación es entendida desde el compositor al performer (el compositor me dice) a través del papel. En ambos casos los performers afirman que poseen sus propias intenciones con la obra en los mismos términos: "decir" con la obra o decidir a partir del "decir" del compositor.

\section{(ii) Intencionalidad del público}

\section{Ejemplo 1}

M - Además, ellos esperan cosas. Esperan ver una persona así, diciendo esas cosas, tocando esas cosas que ellos esperan.

(...)

Están esperando algo los otros, que pase algo. Como que están esperando que yo me comporte de determinada manera para que responda a lo que ellos quieren de mí.

\section{Ejemplo 2}

I - ¿Están esperando que vos hagas algo?

M - Sí, a ver... A mí no me importa mucho, no me influye eso, porque si no, no podría tocar. 
Yo fui y soy público, de muchos años. Pasa el tiempo y también, a lo largo de las edades, distintas edades, uno va con distintas expectativas o buscando distintas cosas. Así que yo sé todas esas cosas que van pasando en las cabezas de los demás. Por supuesto, las proyecto.

Los performers pueden dar cuenta de las expectativas del público, expectativas que identifican en relación a lo que ellos harán en la performance. En el primer caso puede entenderse como un "decir" o una respuesta del performer hacia ellos; en el segundo, el performer atribuye intencionalidades al público considerando sus propias expectativas en su experiencia como público y proyectándolas en los demás.

\section{(iii) Intencionalidades de otros intérpretes}

\section{Ejemplo 1}

I - ¿Escuchás versiones de otros intérpretes?

M - Sí. Las escucho, me parece importante... escuchar como... después construís tu versión.

\section{Ejemplo 2}

M - Yo he tenido así como algunos referentes, del mundo global de guitarristas, como que aprendes de decir: "esto funciona" o "yo coincido con esto". Hay mucho que uno aprende de decir "coincido con esta manera de encarar la música". Entonces, yo escucho Julian Bream y coincido. Aunque después estudiás la obra y decís "esto yo lo haría distinto", pero escuchás y coincidís, porque musicalmente vos te das cuenta que te llega, que lo hace bien, que impacta.

Escuchar versiones de otros intérpretes es una fuente importante que sirve como insumo de la propia construcción de una versión de la obra (Ejemplo 1). Esta construcción puede ser descripta como una empatía hacia la versión del músico (en lo que funciona, en la coincidencia); aunque luego, las intenciones son propias producto del trabajo personal con la obra (Ejemplo 2).

\section{(iv) Intencionalidad del performer}

Ejemplo 1

I - Ya me habías dicho que tenías en cuenta las intenciones del compositor. ¿Cómo llegás a esas intenciones? Dónde surgen... ¿Qué hacés para encontrarte con esas intenciones?

M - Sí, hay intenciones, si. Pero si las tomo en cuenta, a veces sí, y a veces no.

\section{Ejemplo 2}

I - ¿Recibís opiniones de otras personas?

M - Y sí. Acá en casa... icon todos los músicos que hay siempre pasa uno y te dice algo! Sí, sí, claro que sí. Igual, siempre busco lo que quiero decir yo. En última instancia siempre voy a hacer ese recorrido.

I - ¿La última palabra es tuya? ¿A eso te referís?

M - Y sí, claro. Pero bueno, sí me influye. Pueden ser buenas ideas, pueden ser cosas, o pueden ser cosas que uno no se da cuenta que estás haciendo y... 
Estos dos ejemplos muestran claramente que el performer puede entender y evaluar las intenciones (como indicaciones de la partitura o como opiniones) de otras personas, pero que finalmente lo que realiza depende de una decisión propia.

\section{2 de la información no codificada}

Al comienzo de la entrevista los músicos relataron sus comienzos en el aprendizaje del instrumento refiriéndose a el/la primer/a profesor/a y a el/la que influyó su modo de interpretar; con respecto a los últimos, 8 músicos reconocieron la influencia de más de uno, o bien la imposibilidad de considerar a uno solo. Al preguntarles si creían que tenían cosas de ellos o eran como ellos en su manera de interpretar, 6 respondieron afirmativamente mientras que 10 respondieron afirmativamente únicamente en relación a su práctica docente; por otro lado, 3 músicos dijeron no poder reconocer su influencia porque no los habían visto tocar en público. Otras consideraciones importantes al respecto deben hacerse con respecto a la influencia en el modo de tocar. Uno de los músicos dijo que le era imposible identificar una influencia del profesor, y que consideraba haber sido influenciado por otros músicos y colegas con quienes compartió actividades musicales. Finalmente, uno de los músicos dijo haber sido influenciado por intérpretes conocidos (escuchados), a través del sonido y el modo de interpretar.

Por último, con respecto a escuchar interpretaciones de la obra en preparación realizadas por otros músicos, todos excepto uno de los músicos manifestaron considerarlas como una fuente de consulta. En ese caso excepcional, el músico argumentó no realizarlo por una decisión propia de no ser influenciado por otra subjetividad.

\section{Discusión}

En esta primera entrevista nos propusimos describir a la performance en términos de relaciones sociales. Partiendo de los roles sociales del compositor, el performer y el oyente, extendimos el alcance hacia otro tipo de relaciones con los profesores de instrumento y otras personas (músicos, colegas y personas cercanas). Además, consideramos otros tipos de relaciones como la del performer en relación a otros performers (dentro del mismo rol social) y la relación del performer consigo mismo.

Las descripciones de los músicos fueron interpretadas en términos de una comunicación en diferentes direcciones: ya sea desde el músico, hacia el músico, consigo mismo y de un modo recíproco. Los resultados permiten entender que el 
músico construye la interpretación de la obra de un modo intencional en: (i) relaciones humanas concretas; (ii) relaciones a partir de inferencias de la partitura; (iii) relaciones humanas evocadas o imaginadas de personas; y (iv) como personificaciones de la obra y la partitura. Es por esto que consideramos que el performer procede de acuerdo a sus modos de interacción humana aún cuando no está interactuando directamente con ellos. Así, en la construcción del sentido el músico realiza acciones o enacciones de los significados de acuerdo a los modos de la interacción social.

Esta construcción del sentido o el significado es realizada por el músico de manera activa al convocar a un interlocutor real o virtual que incluso puede constituirse en relación a sí mismo. Por ejemplo, algunos músicos se refirieron a la situación de recrear la situación comunicacional adoptando el rol de oyente o público. Ante la posibilidad de considerar que el performer realiza su tarea en solitario, estos resultados podrían estar dando cuenta que el músico no está solo aún cuando está solo.

En la atribución de intencionalidades se pone de manifiesto el modo en el que la música puede ser entendida a través de: (i) atribuciones de acciones corporales humanas (Leman, 2008); (ii) el afecto sugerido por la música que podemos reconocer en ella (Juslin y Sloboda, 2001); y (iii) en un significado que produce una comunicación empática entre performers y audiencia a partir de perfiles vitales energéticos (Martínez, y Pereira Ghiena, 2015). Así mismo, los aspectos corporeizados también son entendidos en la intersubjetividad y la reciprocidad percibida a través de un entonamiento afectivo (Bordoni, Español y De Grande, 2016), en patrones que dan sentido a una interaccción (Malloch y Trevarthen, 2009). Es probable que a través de lo que hemos entendido aquí a partir de las palabras de los músicos nos hayamos acercado a una fenomenología de la agencia: una intencionalidad que poseemos y que entendemos que recíprocamente los otros tienen (Popova, 2015), y que sea esto lo que le permite al performer iniciar una búsqueda de significados en la partitura dentro de un espectro de significados posibles (Bruner, 1986).

Repensando la concepción tradicional de la comunicación desde el compositor por medio del performer hacia el oyente, consideramos que desde la perspectiva del performer la comunicación es llevada a cabo en múltiples direcciones, llevándonos al cuestionamiento de la dirección lineal de la comunicación.

Este tipo de interacciones sociales son llevadas a cabo por el performer, ya sea de un modo real o virtual, atribuyendo intencionalidades y expectativas de los demás agentes con un sentido de autonomía o agencia. Habiendo descripto este tipo de entramado social en la actividad del performer, nos proponemos avanzar en la siguiente entrevista hacia la consideración del acto de comunicación musical que 
realiza el performer en términos análogos al acto narrativo. Para esto, además del rol comunicativo del performer, se debe profundizar en los aspectos agenciales de su actividad que dan cuenta de una producción o construcción propia (la narración de la obra) para ir más allá de la partitura y organizar lo narrado. 


\section{ENTREVISTA 2}

\section{Objetivos}

Conocer la actividad del músico performer durante la preparación de la obra y su posterior performance, a través de sus descripciones de la experiencia. Describir a la performance musical como una narración que se establece en la comunicación entre un performer y el público.

\section{Metodología}

Se realizó una entrevista a los 11 músicos instrumentistas que habían participado en la Entrevista 1. Las entrevistas fueron conducidas, grabadas, transcriptas y analizadas del mismo modo y utilizando los mismos aparatos. Con un promedio individual de 41 minutos, se registraron 7 horas y 31 minutos (6hs. $30 \mathrm{~ms}$.) en el total de las 11 entrevistas.

\subsection{Guión de la entrevista}

El guión de la entrevista contenía preguntas acerca de concepciones acerca de la interpretación de las obras musicales, su aporte personal desde la interpretación, y su experiencia sentida con respecto a la performance de la música, el público y el tiempo. Estas concepciones eran indagadas desde el proceso de la preparación de una obra, pasando por el ensayo y hasta el momento de la performance.

\subsection{Análisis de los datos}

Se seleccionaron 83 fragmentos de la entrevista que se organizaron en relación a diferentes temáticas: (i) la interpretación; (ii) la performance; (iii) el performer; y (iv) el tiempo. La información se organizó inicialmente de acuerdo a las siguientes preguntas:

(i) ¿qué define la interpretación? ¿qué acciones se realizan? ¿qué ocurre en la interpretación? ¿cómo construye su propia interpretación?

(ii) ¿cómo se comunica en la performance? ¿cómo se involucra al público?

(iii) ¿cómo se auto-define el performer? ¿qué lo define? ¿en relación a qué se define? ¿cómo se siente? ¿cómo incide lo que hace? ¿qué rol adopta? ¿cómo afirma o cambia su rol/función con respecto a la vida cotidiana? 
(iv) ¿cómo concibe el tiempo de la música? ¿se adueña de ese tiempo en la performance? ¿puede compartir el tiempo con el público?

La guía de codificación se organizó de acuerdo a las anotaciones y observaciones sobre las temáticas y sub-temáticas sobre las que se realizaron codificaciones iniciales en el software. Los nodos (307) se agruparon en 5 categorías diferenciadas: Narrar (120), Personal (64), Afectos (64), Dinámico (30) y Tiempo (29).

En primer lugar, Narrar abarcó un grupo de descripciones acerca de la performance dirigida hacia el público como un acto comunicativo. En la Tabla 1 se observan los nodos obtenidos en la codificación que pueden ser agrupados en la categoría Narrar. Con una frecuencia de 120 nodos en el total de los 11 Casos, se consideró que Narrar puede ser descripta a través de los siguientes nodos: Comunicar (37), Crear (26), Enunciar (14), Expresión (11), Actuar (8), Es de todos (8) y Otro lugar (8).

Comunicar (37) es un nodo propuesto de antemano en la formulación de las preguntas. Basados en los resultados de la entrevista anterior, en esta entrevista intentamos profundizar en la intencionalidad comunicativa de los performers. Casi todos los músicos (10) se refirieron a comunicar en la performance en términos de la realización de una actividad dirigida hacia el público, lo que se consideró de modo análogo entre el receptor y el narratario. Algunos músicos también caracterizaron esta relación en términos de una conexión (6).

Crear (26) agrupó sub-nodos que describen acciones en un sentido de creación o invención, que son potencialmente determinantes para considerar una actividad del performer sobre la obra compuesta por otro (el compositor), en oposición con una performance reproductiva. Formar, dar vida, construir, transformar, proyectar, se consideraron como sub-nodos descriptivos de la acción creadora para la narración de la obra musical. Con respecto a su posicionamiento frente a la obra, el nodo Determinar (8) puede describir el modo en que 4 performers pueden adoptar un rol narrativo intencional, como lo es presentar un punto de vista o mirada, convencer, provocar y dar sentido en la performance. Actuar (8) se refiere a las acciones y gestos que constituyen la interpretación en la performance.

El nodo Enunciar (14) permite considerar a la performance de una obra de un modo análogo al acto de una narración oral; dentro de los sub-nodos codificados, 7 músicos lo describieron en términos de un decir (10). En un sentido similar, se codificaron 3 sub-nodos de 2 músicos que se refirieron a un acto de narrar o contar de un modo literal. 
Tabla 1. Frecuencias y Casos de los nodos y sub-nodos de la Categoría Narrar.

\begin{tabular}{|c|c|c|c|c|}
\hline Categoría & Nodos & Sub-nodos & Frecuencia & Casos \\
\hline \multirow{7}{*}{\multicolumn{2}{|c|}{ NARRAR }} & & 120 & 11 \\
\hline & & & 14 & 8 \\
\hline & & Narrar, Contar & 3 & 2 \\
\hline & & Mensaje & 2 & 2 \\
\hline & & Discurso & 1 & 1 \\
\hline & & Decir (compositor) & 1 & 1 \\
\hline & & Decir (performer) & 10 & 7 \\
\hline \multirow{3}{*}{\multicolumn{2}{|c|}{ Actuar }} & & 8 & 7 \\
\hline & & Gesto, Actuación & 5 & 3 \\
\hline & & Energía & 3 & 2 \\
\hline \multirow{5}{*}{\multicolumn{2}{|c|}{ Determinar }} & & 8 & 4 \\
\hline & & Punto de vista, visión, mirada & 5 & 2 \\
\hline & & Convencer & 1 & 1 \\
\hline & & Provocar & 1 & 1 \\
\hline & & Sentido & 1 & 1 \\
\hline \multirow{16}{*}{\multicolumn{2}{|c|}{ Crear }} & & 26 & 7 \\
\hline & & Dar vida & 2 & 1 \\
\hline & & Formar & 1 & 1 \\
\hline & & Proyectar & 1 & 1 \\
\hline & & Llevar & 3 & 3 \\
\hline & & Fluir, Soltar & 4 & 5 \\
\hline & & Construir & 2 & 1 \\
\hline & & Transformar & 1 & 1 \\
\hline & & Modificar & 1 & 1 \\
\hline & & Recrear & 2 & 2 \\
\hline & & Posibilidades & 1 & 1 \\
\hline & & Inventar & 1 & 1 \\
\hline & & Jugar & 1 & 1 \\
\hline & & Imaginación creadora & 2 & 2 \\
\hline & & Magia, Fantasía, Irrealidad & 3 & 3 \\
\hline & & Moldear & 1 & 1 \\
\hline \multirow{8}{*}{\multicolumn{2}{|c|}{ Comunicar }} & & 37 & 10 \\
\hline & & Con el público & 5 & 3 \\
\hline & & Consigo mismo & 2 & 2 \\
\hline & & Narratario & 19 & 10 \\
\hline & & Conexión & 8 & 6 \\
\hline & & Compartir & 1 & 1 \\
\hline & & Intercambio & 1 & 1 \\
\hline & & Ida y vuelta & 1 & 1 \\
\hline & Expresión & & 11 & 6 \\
\hline & Es de todos & & 8 & 7 \\
\hline & Otro lugar & & 8 & 5 \\
\hline
\end{tabular}


En cuanto a lo que se comunica, 6 músicos se refirieron a la Expresión (10), que es entendido como el contenido de la narración. Asímismo, 7 músicos dijeron que eso que se comunica pertenece a todos los que participan en el evento de la performance. Finalmente, 5 músicos se refirieron a su lugar en la performance como Otro lugar (6); de un modo similar, 3 músicos se refirieron a lo mágico o irreal, mientras que 2 más enfatizaron la importancia de la imaginación.

Tabla 2. Frecuencias y Casos de los nodos para la Categoría Personal.

\begin{tabular}{|c|c|c|c|}
\hline Categoría & Nodos & Frecuencia & Casos \\
\hline \multirow[t]{19}{*}{ PERSONAL } & & 64 & 11 \\
\hline & Propio & 13 & 7 \\
\hline & Instinto, Interno, Intuición & 4 & 3 \\
\hline & Subjetividad & 2 & 1 \\
\hline & Elegir, Decidir, Determinar & 6 & 5 \\
\hline & Carácter, Impronta & 1 & 1 \\
\hline & Personalidad, Yo & 11 & 6 \\
\hline & Control & 1 & 1 \\
\hline & Autenticidad & 2 & 2 \\
\hline & Intencionalidad, Intención & 3 & 3 \\
\hline & Búsqueda & 5 & 5 \\
\hline & Necesidad & 3 & 3 \\
\hline & Objetivo, Propósito & 2 & 2 \\
\hline & Convicción & 1 & 1 \\
\hline & Sinceridad, Honestidad & 1 & 1 \\
\hline & Compromiso, Responsabilidad & 2 & 1 \\
\hline & Fidelidad a uno & 2 & 2 \\
\hline & Libertad & 4 & 1 \\
\hline & Estar / No estar & 1 & 1 \\
\hline
\end{tabular}

La segunda categoría, Personal, es la que permite describir la práctica del músico de acuerdo a una intencionalidad que se define como Propia (13 nodos en 7 casos) en la producción musical. Algunos músicos definieron éstos aspectos personales como una cuestión de Elección, decisión o determinación ( 6 nodos en 5 casos); mientras que otros lo hicieron a través de la Intuición, instinto o cuestiones internas (4 nodos en 3 casos), o como resultado de una Búsqueda personal (5 nodos en 5 casos). Todos estos aspectos de lo personal pueden ser también definidos a través de los nodos Personalidad, Yo (11 nodos en 6 casos). En la Tabla 2 pueden observarse más nodos que caracterizan aspectos de lo que hemos considerado como personal. 
Afectos incluye contenidos afectivos, emocionales, experiencias sentidas y sensaciones como aspectos esencialmente humanos en las descripciones de los músicos. Este conjunto de nodos, sin embargo, no pretende realizar distinciones conceptuales entre afectos, sentimientos y emociones. En su lugar, tomamos las palabras de los músicos como ocurren en las expresiones originales.

Entre las descripciones de los performers se destacan Sentir (10 nodos en 9 músicos), las sensaciones en el Cuerpo o físico (9 nodos en 6 músicos) y la Emoción (9 nodos en 5 músicos). Por último, 7 músicos (10 nodos) se refirieron a aspectos positivos de la tarea musical en el Placer, goce, disfrute, etc., como aspectos individuales y compartidos con el público en la performance. En la Tabla 3 pueden observarse la totalidad de los nodos y los casos.

Tabla 3. Frecuencias y Casos de los nodos para la Categoría Afectos.

\begin{tabular}{cccc}
\hline Categoría & Nodos & Frecuencia & Casos \\
\hline \multirow{2}{*}{ AFECTOS } & & $\mathbf{6 4}$ & $\mathbf{1 1}$ \\
& Afecto & 4 & 3 \\
Emoción & 9 & 5 \\
Sentir & 10 & 9 \\
Sensaciones & 4 & 3 \\
Estados & 4 & 3 \\
& Placer, Goce, Disfrute, Satisfacción, Felicidad & 10 & 7 \\
Vértigo, Adrenalina & 2 & 2 \\
Expectativa & 2 & 1 \\
Asombro, Sorpresa, Locura & 3 & 3 \\
Diversión & 1 & 1 \\
Cariño & 1 & 1 \\
& 2 & 2 \\
Serenidad, Placidez, Ternura & 1 & 1 \\
Sensibilidad & 2 & 2 \\
Vivencias pasadas & 9 & 6 \\
Cuerpo, Físico & & \\
\hline
\end{tabular}

Lo Dinámico se refiere a la variación en el tiempo de la música en la preparación de la obra y la performance, así como también en la percepción personal del músico. En la Tabla 4 puede observarse la distribución de los nodos dentro de la categoría. En algunos casos (4) hemos visto que esto puede deberse a aspectos de lo Indeterminado, incierto o impredecible en la performance de la obra, mientras que para Auto-percepción del músico (13 nodos en 10 casos) puede deberse a: (i) la variación en la producción musical con respecto al estado personal, según el momento o situación en el ensayo y la performance (Otros yo); (ii) la sensación de Ser otro en el momento de la práctica musical; o (iii) cierta consciencia de un Cambio de rol. 
Tabla 4. Frecuencias y Casos de los nodos para la Categoría Dinámico.

\begin{tabular}{cccc}
\hline Categoría & Nodos & Frecuencia & Casos \\
\hline \multirow{2}{*}{ DINÁMICO } & & $\mathbf{3 0}$ & $\mathbf{1 1}$ \\
& Auto-percepción - Otros yo / Ser otro / Cambio de rol & 13 & 10 \\
& Maduración & 2 & 2 \\
Renovación & 1 & 1 \\
Modificación & 2 & 3 \\
Cambio, Diferencia & 3 & 2 \\
Adaptarse & 2 & 4 \\
& Indeterminado, Incierto, Impredecible & 4 & 1 \\
Significado & 1 & 1 \\
& Descubrir & 1 & 1 \\
\hline
\end{tabular}

Tabla 5. Frecuencias y Casos de los nodos y sub-nodos de la Categoría Tiempo.

\begin{tabular}{|c|c|c|c|}
\hline Categoría & Nodos & Frecuencia & Casos \\
\hline \multirow[t]{15}{*}{ TIEMPO } & & 29 & 9 \\
\hline & Tiempo propio & 6 & 6 \\
\hline & Tiempo de la música & 3 & 3 \\
\hline & Tiempo compartido & 3 & 3 \\
\hline & Tiempo de la performance & 5 & 5 \\
\hline & Tiempo del ensayo / estudio & 2 & 2 \\
\hline & Tiempo del compositor & 2 & 2 \\
\hline & Tiempo virtual & 1 & 1 \\
\hline & Tiempo vivido & 1 & 1 \\
\hline & Tiempo construído & 1 & 1 \\
\hline & Modificar el tiempo & 1 & 1 \\
\hline & Organizar el tiempo & 1 & 1 \\
\hline & Actor del tiempo & 1 & 1 \\
\hline & Movimiento & 1 & 1 \\
\hline & Sonido & 1 & 1 \\
\hline
\end{tabular}

Con respecto al Tiempo, no se observaron demasiados agrupamientos en las frecuencias que puedan servir a una caracterización general. Las preguntas específicas que indagaban la relación entre la música y el tiempo tenían la intención de obtener nodos que describieran las concepciones de los performers sobre el rol del tiempo en la performance. En la Tabla 5 pueden observarse algunas tendencias, de las cuales las más importantes son las de la consideración de un Tiempo propio (6), Tiempo de la performance (6), el Tiempo de la música (3), y el Tiempo compartido con el público (3). 


\section{Resultados}

Los datos son ahora repensados y entendidos volviendo a los fragmentos seleccionados de las entrevistas, para realizar descripciones de lo narrado y cómo esto es narrado, además de caracterizar al performer como un narrador entendido en la relación que establece con un narratario. En la Tabla 6 se presenta la información comparada entre los casos. A continuación, se presentan los casos seleccionados para la presentación de los resultados, acompañado de un breve párrafo que describe las consideraciones realizadas en el análisis.

Tabla 6. Categorías, nodos y sub-nodos que describen los análisis presentados de casos.

\begin{tabular}{|c|c|c|c|c|c|}
\hline Caso & Narrar & Personal & Afecto & Dinámico & Tiempo \\
\hline 1 & Expresión, Fluir & Propio & $\begin{array}{l}\text { Sensación, } \\
\text { Placentero, } \\
\text { Felicidad, } \\
\text { Emocional, } \\
\text { Físico }\end{array}$ & Indeterminado & $\begin{array}{l}\text { Tiempo de la } \\
\text { performance (de } \\
\text { principio a fin) }\end{array}$ \\
\hline 2 & $\begin{array}{l}\text { Expresión, Crear } \\
\text { (recrear), Enunciado } \\
\text { (Decir del compositor y } \\
\text { del performer), } \\
\text { Narratario }\end{array}$ & Propio & - & Cambio & - \\
\hline 3 & Narrar, Crear (recrear) & $\begin{array}{l}\text { Intencionalidad, } \\
\text { Propio }\end{array}$ & Emoción & - & - \\
\hline 4 & $\begin{array}{l}\text { Decir del performer, } \\
\text { Determinar, Convencer }\end{array}$ & $\begin{array}{l}\text { Intuitivo, Libertad, } \\
\text { Convicción, } \\
\text { Fidelidad a } \\
\text { uno }\end{array}$ & Emoción & Indeterminado & - \\
\hline 5 & $\begin{array}{l}\text { Acto, Llevar, } \\
\text { Determinar, } \\
\text { Provocar }\end{array}$ & Objetivo & Sorpresa & Cambio & $\begin{array}{l}\text { Tiempo de la } \\
\text { performance }\end{array}$ \\
\hline 6 & Crear, Posibilidades & $\begin{array}{l}\text { Intencionalidad, } \\
\text { Propio }\end{array}$ & Disfrutar & Cambio & $\begin{array}{l}\text { Tiempo del } \\
\text { ensayo y de la } \\
\text { performance }\end{array}$ \\
\hline 7 & $\begin{array}{c}\text { Dar vida, } \\
\text { Comunicación, } \\
\text { Narratario, Es de todos }\end{array}$ & - & - & - & $\begin{array}{l}\text { Tiempo de la } \\
\text { performance }\end{array}$ \\
\hline 8 & $\begin{array}{l}\text { Enunciado, Mensaje, } \\
\text { Decir del performer, } \\
\text { Acto, Gesto, Energía, } \\
\text { Expresión, Narratario }\end{array}$ & Impronta & $\begin{array}{l}\text { Locura, } \\
\text { Serenidad, } \\
\text { Placidez }\end{array}$ & Maduración & - \\
\hline 9 & $\begin{array}{l}\text { Expresión, Determinar, } \\
\text { Punto de vista, Acto, } \\
\text { Fluir, Narratario }\end{array}$ & Propio & $\begin{array}{l}\text { Sensación, } \\
\text { Vértigo, } \\
\text { Adrenalina, } \\
\text { Disfrutar }\end{array}$ & $\begin{array}{l}\text { Cambio de rol, } \\
\text { Indeterminado }\end{array}$ & $\begin{array}{l}\text { Tiempo de la } \\
\text { performance }\end{array}$ \\
\hline
\end{tabular}




\section{Caso 1}

I - ¿Qué te parece que es importante para llegar a interpretar una obra?

M - Lo más importante - bueno, es una expresión pero, que encierra muchas cosas, no sé si podría precisar en su totalidad- es lograr que esa obra, respetando todo lo que está en el papel, respetando sabiendo que lo que está es de una enorme amplitud de lectura, uno es consciente de eso. Pero respetando lo que está uno pueda hacer de esa obra que sea suya, esa sensación que uno la puede hacer como si hubiera salido de la cabeza de uno, no que es mía, que uno la pueda hacer con esa frescura, no actuarla o sobre-actuarla, recuperar eso. Si uno logra eso en una interpretación es muy placentero, se siente muy feliz. Creo que uno tiene la sensación de que logró algo, de que hizo algo bueno porque uno no siente que está artificialmente tocada.

I - ¿Hay una manera de hacerla tuya?

M - Sí, es larguísimo. Es hacerla... Cuando uno dice "hacerla suya" es intelectual, emocional y físicamente suya. Sentir que la obra fluye, que uno no está forzándose a tocar pasajes que no entendés ni para donde van, que los pasás porque no sabés bien qué hacer. Es muy difícil, creo que no sé si uno tiene alguna vez -uno, no digo los grandes-, esa sensación que de principio a fin uno la abarcó pudiendo lograr eso. Pero ese es el norte.

En este fragmento podemos interpretar que el músico considera -desde un respeto- una amplitud de lectura (Indeterminación) para abordar la obra. Lo narrado es identificado como la Expresión, sentir que la obra Fluye de principio a fin (Tiempo) como el resultado de hacerla suya (Propio) intelectual, emocional y físicamente (Afecto).

\section{Caso 2}

I - ¿Qué es lo más importante para interpretar una obra?

M - Es importante entender lo que el compositor quiso decir.

I - ¿Es solamente lo que quiso decir el compositor?

M - No, yo también quiero decir lo mío. Es una transmisión al auditorio, a la persona que me está escuchando. A la persona le llega o no le llega la música.

$\mathrm{I}-$ ¿Y a quien le pertenece eso? ¿es de alguien?

$\mathrm{M}$ - Yo lo tomo y se va al auditorio. Yo lo hago y el otro recoge las cosas que yo hago. Yo le pongo cosas. Y del compositor le pongo un poco de lo que hizo. Le puedo modificar algo pero sin sacarle la esencia, entonces llega.

I - La otra vez me decías que el intérprete recreaba la música...

M - Claro, agarra la obra, se la hace propia, sin cambiarle la parte técnica. En lo clásico uno recrea la parte expresiva, porque a veces en la partitura no está todo escrito. El intérprete lo que hace es... recrea lo que hizo el autor.

Cuando uno escucha a un buen intérprete, que es maravilloso, uno ve la música escrita de acuerdo a lo que ellos tocan. Parece que escribieron lo que ellos están tocando, no que están tocando lo que está escrito.

I - ¿Y cuando estás trabajando, en ese re-crear la obra es siempre la misma? O cambia?

M - Y sí, cambia. Hasta que vos encontrás el lugar exacto. A veces uno lo cambia, pero muy poco. Cuando tengo que tocar delante de la gente agarro una de las cosas que he hecho y lo pongo ahí. La obra siempre está escrita, lo que uno hace es recrearla, sin salirse de lo escrito. Modificarla no. 
Aquí Narrar se refiere a la Expresión, como un Enunciar que combina el Decir del compositor con el del performer, en una acción de recrear (Crear). Entendido con algo Propio, la transmisión (Comunicación) que considera al Público puede entenderse como una relación entre un narrador y el Narratario. Lo Dinámico se observa en el Cambio de la obra que se produce en la recreación.

En estos dos primeros casos los performers expresan que quieren lograr (Caso 1) o lo logran (Caso 2) hacer propia la obra. Lo particular es el modo en que lo expresan: aún sabiendo que la obra no es suya, que no pueden modificarla, consideran lo que nosotros entendemos como una intención hacia la obra. Si lo pensamos en términos de una narración de la obra, el performer debería estar narrando algo preexistente, donde la narración surge como una entidad posible de dar cuenta, o contar (en el caso de la literatura) una historia. Más inquietante aún es considerar que la obra es re-creada y por lo tanto cambia (Caso 2). Si consideramos que lo que se narra es lo que previamente existe y está en el papel, y que la narración se constituye en la creación de una performance como una segunda entidad, nos estaríamos acercando a una posible solución a la relación análoga.

\section{Caso 3}

I - ¿Te parece que hay una sola manera de tocar una obra?

M- No. Si no, yo no distinguiría una Argerich de un Barenboim.

I - ¿Cómo hacés para saber cuál es la que es para vos, la manera de tocar tuya?

M - Porque la intencionalidad... digamos, vos bajás la nota que está. Vos la bajás fuerte, piano, como te van pidiendo. Pero cuán piano, cuán fuerte, o el contenido que vos le ponés a esas notas no es el mismo que le puso el otro. Aunque si la estudias con un maestro te va a dar... toda su visión de la obra. Pero después hay un punto en el que vos empezás a reinterpretar la obra, no desde tu punto de vista, desde tu emoción. Entonces la vas cargando de un montón de significados que hacen que vos bajes un poquitito diferente de lo que baja cada uno. ¿no? O que le pongas un poquito más de peso... todo eso se traduce y no hay forma de... todo eso se traduce al sonido. ¡no hay forma de explicarlo en palabras! Para mí. Y si buscás la forma es como: "¿para qué vamos a destruir este misterio?". La palabra, al menos en música, no llega a narrarte la emoción. La emoción es la emoción.

En este caso encontramos una referencia directa a la narración, en este caso es la narración de la Emoción (Afecto). Este Narrar es algo que se distingue de la palabra: "la palabra no llega a narrarte la emoción", es una Intencionalidad (Personal) para Crear, que puede ser descripto como reinterpretar (Recrear) la obra. La diferencia entre diferentes músicos, en el contenido que se pone a las notas puede considerarse como algo Propio del performer.

El contenido emocional es lo más importante en este fragmento. Es una narración sin palabras, lo cual nos acerca a una narración musical. La emoción 
entonces puede constituirse como el contenido de la narración en música sin igualar a la narración verbal. Esto requiere de una reinterpretación de la obra, una que sea propia del performer; en este caso la narración sería una creación (la obra reinterpretada) a partir de una intencionalidad propia, que la diferencia de otras intencionalidades (de otros performers). Esa narración contiene significados en la traducción de la obra al sonido.

\section{Caso 4}

I - ¿Te parece que hay una sola manera de tocar una obra?

M - No. Está a la luz de las diez millones de interpretaciones que la obra pueda tener. Probablemente para uno termina cerrando de una manera o tiende a acercarse a una manera de tocarla que es la tuya, un poco.

I - Entonces ¿cómo hacés para saber cuál es la manera en la que vos deberías tocar una obra? Un poco ya lo hablamos...

M - Si, en principio me guío mucho por la cuestión intuitiva, emocional. Decir "me gusta" llevar la obra para este lado. Me gusta, me convence... Siempre a mi me gustó, aún dentro de este concepto de "libertad" que estaba diciendo, tratar de ser fiel al estilo igual. Creo que eso no se contrapone. Uno puede tener libertad tocando Bach y de repente estás decidiendo .... Son cosas que definen muchísimo la sonoridad y todas son en el estilo. Tratar de ajustarse a esa sonoridad del estilo.

I - Sí, lo que más me importa es ver si vos llegás a construir una intención que reconocés como propia, ¿no?

M - Sí, yo creo que dentro de este concepto de "libertad". Yo te digo libertad y en realidad es como una especie de fidelidad a uno mismo, de hacer las cosas con convicción y a fondo, y que todas las notas tengan un lugar en la interpretación, que tengan una función, una manera de decir. Que uno nunca toque las notas sin saber cómo las está tocando.

El músico se encuentra con una amplia gama de posibilidades de interpretación de una obra (Indeterminación). Lo Intuitivo se vincula con lo Emocional. Este performer considera la importancia de que la interpretación convenza (Convencer) ${ }^{68}$, y dentro de Narrar, puede describirse como una manera de Decir. En lo Personal, la Libertad y la Fidelidad a uno no se contrapone con ser "fiel al estilo"; mientras que la intencionalidad es descripta como la propia Convicción.

Si el narrador es quien cuenta la historia a su modo, el concepto de "libertad" está bien encaminado. Un performer que no pretenda una interpretación propia difícilmente pueda ser considerado como un narrador de la obra. Es destacable en este fragmento cómo la "fidelidad a uno mismo" se contrapone con la idea de "ser fiel a

\footnotetext{
${ }^{68}$ Podemos afirmar esto por lo enunciado por este músico en otros pasajes de la entrevista, por ejemplo: "Vos podés escuchar versiones por ahí.. Que no dicen nada, y versiones como la de Julian Bream, por ejemplo, y vos las ponés, las estudias y por ahí habría alguna cosa que podría ser distinto pero creo que no hay ninguna duda que la versión convence ¿desde qué lugar convence? Yo creo que desde este lugar que vos escuchás como una continuidad en la expresión... como un actor ¿no?”
} 
la obra" (ver Capítulo 1), aunque de todos modos se puede al mismo tiempo ser "fiel al estilo". Aunque el performer no puede modificar la obra, la metáfora de llevar a la obra para un lado indica que las diferentes interpretaciones pueden llevar a la obra para diferentes lados. Convencer, hacer las cosas con convicción y a fondo hacen que el performer construya una meta clara con respecto a la obra; a diferencia de tocar la obra sin saber cómo lo hace, la manera de decir (otra analogía posible para narrar) la obra en la interpretación, o la voz narradora pueden ser modos posibles de entender al músico como un narrador.

\section{Caso 5}

I - ¿Tenés un ideal al cual llegar o construir "la" interpretación de la partitura?

M - Depende de lo que vos toqués. Yo ya tengo un objetivo. Quiero lograr esto. Quiero lograr que esto impacte en tal lugar. Y ver cómo lo hago, para que pase.

I - ¿Y si no pasa?

M - Y si no pasa, en el momento en el que estoy tocando lo arreglo.

I - Está bien, como que lo vas llevando.

M - Sí, sí, sí.

En este caso, la Intencionalidad del músico está dirigida a una meta (Objetivo) que es temporal: impactar (Determinar, Provocar). Este Narrar, consiste en Llevar (Acto) al público hacia la sorpresa, y en producir un Cambio de acuerdo a si esto finalmente sucede en la performance (Dinámico). ${ }^{69}$

Cuando Popova dice que atribuímos una intención a una consciencia narrante, entendemos que existe una estructura de acción que integra la sucesión de eventos en un modo causal que se dirige hacia una meta que es la meta del narrador. En este fragmento entendemos que el performer tiene un objetivo (meta), que ese objetivo es temporal hacia un lugar (temporal), hacia donde se dirige la estructura de acción, hacia un punto de impacto: provocar la sorpresa (emoción) del público.

\footnotetext{
${ }^{69}$ Hemos realizado para este fragmento consideraciones que se complementan con palabras del performer durante las Entrevistas 1 y 2 . Sin acudir a ellas, el análisis es más complejo de entender por el lector de la tesis. Ambos fragmentos se sustentan en la relevancia que el performer le otorga a la sorpresa tanto en una novela literaria como en su performance de la música. En la primera entrevista nos dijo: " $Y$, vos leés una novela, tenés un libro. Cualquier novela linda, "ay, ¿cómo será?" Y empezás a leer. Y ya te dejás llevar por el libro. Es lo mismo, leés la partitura y te dejás llevar por la música que sale, y te sorprendés, porque no te lo esperás lo que viene. (...) Una música buena, si te sorprende es linda. Lo mismo que un libro, tenés un libro todo aburrido lo cerrás y no lo leés más." En la segunda entrevista: "Por ejemplo quiero que en este momento, que sea crucial, que la gente se quede impactada, que sea una cosa nueva, que no sea predecible. Y si veo que la gente lo percibe, me pongo re contenta. Eso le aporto. Que haga eso, que le pase eso."
} 


\section{Caso 6}

I - Y una vez que ya empezás a tocar la obra, ¿cómo le vas dando forma, o cómo se va trabajando?

M - Según la expectativa, ahí ya es mía, ahí ya empiezo a disfrutarla. Es como disfrutar un hijo. No es lo mismo disfrutarlo recién nacido que a los dos años, que a los tres años. Él va cambiando, le estás dando posibilidades de que cambie, de que mejore. Entonces, cada vez que la ejecutás, esa es la gran expectativa y el interrogante, ¿no? “¿cómo me saldrá?", "iuh, me equivoqué de dedo!", eso es circunstancial. Una pifiada de dedo, "se me cayó la batuta".. Y no se para la orquesta, si es tú orquesta. Con la guitarra, con lo que sea, pienso que no es lo más importante. Aún desde el punto de vista expresivo, no creamos que siempre va a salir mejor o diferente.

En el aspecto Personal de la interpretación de la obra, una vez que el performer la considera como algo Propio, implica una Intencionalidad entendida en relación a una expectativa, aunque también puede ser un interrogante. Este Disfrutar (Afecto) es descripto de un modo análogo para la relación con un hijo, y el Cambio (Dinámico) de acuerdo a las Posibilidades (Crear) y aún en lo circunstancial (Indeterminación) que el músico le va dando. ${ }^{70}$

En este caso, cuando el performer se refiere a hacer "suya" la obra, su descripción viene de la mano de dos metáforas. Por un lado, se alude a la personificación (Lakoff y Johnson, 1980) de la obra; por el otro, a la metáfora de un hijo, que puede ser entendida aquí como una "creación" propia; es crear vida, es también algo que, al tener vida propia, se torna impredecible, pero lo impredecible es algo que le permite disfrutarla. Al igual que en los Casos 1 y 2 , nos encontramos aquí con alusiones a que lo que estaría cambiando es la obra, a partir de las acciones del performer: "él va cambiando, le estás dando posibilidades de que cambie, de que mejore".

\section{Caso 7}

I - ¿Existe algo para comunicar?

M - Hay una música que se está tocando en particular. No estás tocando cualquier cosa, pero luego tampoco la estás tocando a cualquiera. Más que nada tiene que ver con esto que te decía que si uno logra que las cosas se hagan, que recuperen naturalidad, que se hagan vivas, lo que transmitís es eso. Es la obra hecha vida, eso es lo que tiene el hacerlo en vivo, que no tiene cuando no está el intérprete ahí en el escenario.

I - ¿A quién pertenece eso?

M - A una persona no. O a algo puntual no. Ese sí es el evento, que no es el acontecimiento, es el evento, es eventual. Es el que está sentado, son los que están sentados arriba, abajo del escenario. Es todo, por supuesto la música obviamente.

70 Aquí Posibilidades, además de ser entendido como Crear (el músico le va dando posibilidades a la obra para que cambie), es considerado como un aspecto de la Indeterminación. 
En este fragmento, Narrar es entendido como Dar vida, un Acto que en la Comunicación implica a un público (Narratario) en la performance. La pertenencia de lo comunicado (lo narrado) es aquí entendida como algo que Es de todos.

La performance, entendida como el acto de dar vida a la obra, y la transmisión de lo vital hacia un público en particular sitúa al performer en un contexto de comunicación. Aquí el narrador y el narratario son claramente distinguibles y las intencionalidades del músico se orientan hacia allí. En el contexto actual, con estas características, es el performer es quien lleva adelante las acciones para crear o dar vida a la obra; el compositor pertenece a otro contexto y ya no está para hacerlo; performer y compositor tienen roles diferentes en esta distinción. Si lo que puede ser comunicado es lo descripto por este performer, entonces el performer es el narrador que da vida a la obra para transmitirla en un contexto en donde lo comunicado (según el performer) es de todos.

\section{Caso 8}

I - ¿Cómo es la situación de estar tocando en público? ¿Qué cosas creés que hacés vos y qué cosas hacen los demás?

M - El concierto es como una experiencia personal de maduración de una obra. Cuando vos tocás en público la obra... ya tenés una impronta distinta, se va madurando y cuanto más la toques, mejor digamos, ¿no? O sea, esto es un nivel. Y una realidad que tenemos que hacer obviamente y está muy bien.

Yo lo que intento ahí es qué puede dejar uno ahí. Qué energía uno puede dejar ahí, que mensaje uno puede dejar ahí. Y no mensaje en el término emisor-receptor, eh. Sino qué cosa de esa vibración que sucede en una obra musical. En cada gesto, en cada tránsito del brazo sobre el teclado pasan cosas que llegan a la gente, en algún punto lo perciben. Trato -trato, porque no está todavía absolutamente incorporado eso, son búsquedas realmente- que lo que uno está expresando ahí tenga que ver como un "decir" de lo que vos interpretás... la locura, la serenidad, la placidez, lo expresivo. Todo eso, que uno encuentra en una obra.

En la performance, la Impronta Personal del músico está implicada en un proceso Dinámico de Maduración de la obra. En este contexto, Narrar es descripto como el Enunciado de un Mensaje o un Decir del performer. En la Expresión, se lleva a cabo un Acto donde el Gesto y la Energía son percibidos por el público (Narratario), aunque no en términos de emisor-receptor. Ese Decir de lo que se interpreta en la obra como la locura, la serenidad y la placidez puede ser entendido en el sentido de la categoría Afecto.

Este pasaje presenta una serie de descripciones corporales y un contenido (energía, vibración) que surgen como un mensaje "en otros términos". Cuando realiza esta distinción (que el mensaje no es abordado en los términos del emisor-receptor) abre la posibilidad de pensar la relación entre el narrador y el público de un modo 
diferente. Este mensaje podría ser entendido a partir de las teorías del embodiment, para explicar el modo en que se puede compartir o entonar afectivamente con los otros (Stern, 1985), el gesto y la energía en la performance (Hatten, 2004), los afectos de la vitalidad (Stern, 2010), y la cognición corporeizada de la música (Leman, 2008).

\section{Caso 9}

I - ¿Te sentís otro cuando tocás?

M - Hay como un cambio de rol. Hay una sensación distinta.

I - ¿Y cómo sería?

M - Es como que de repente decís "upa, que hago acá?" ¿no? a veces me pasa. El tocar en público tiene así como una cosa así vertiginosa, así, hay como una cosa como de adrenalina que no sé... uno dice que está bueno, pero antes te da miedo. Yo soy de esos que en el momento lo disfruto, después lo disfruto, pero los cinco minutos antes estoy tenso, ¿no?

Aparte estás como en una vidriera, pasás de estar de espectador... Y que cada cosa que hacés tiene... esa es una sensación, sí, sí, muy de tocar en público. Estás tocando e inconscientemente esta sensación de que sos el que está produciendo los sonidos ¿no? en el momento. O sea que si vos dejás de tocar... es como esa cosa que a veces dicen del que están en el borde del precipicio y que dicen "uh, yo acá si me tiro..." ¿no? Estás tocando y decís "si me equivoco, si dejo, de tocar, si me olvido, si..." ¿no? Hay como una sensación así, como que sos el responsable de ese momento, esa cuestión de esa responsabilidad que tenés en ese momento.

Por ejemplo, tocar la gran obertura, que es una obra que es virtuosística, que es difícil, que a mi me ha gustado tocarla pero siempre estoy sudando la gota hasta el último instante que la estoy estudiando, y cuando la estoy tocando también. Y también por esa cuestión de que vos sabés que la tocás... igual con respeto siempre, no es que uno va a subestimar, pero yo digo "está bueno que esta obra suene, y que la pueda escuchar determinada persona, aún con mis errores, con las cosas que no suenen perfectas. Porque finalmente no es lo más importante, aún en una obra, dentro de un concepto de perfección, sino dentro de estas cuestiones de expresión y todo. Y que uno a veces con el repertorio estás mostrando el punto de vista, tu punto de vista.

Pero bueno, en el momento no deja de tener esa cuestión así como vertiginosa, o sea, lo que es en público, aún tocando bien y sintiendo que....

Lo que tiene el tocar en público, especialmente, es que requiere una actitud mental de ponerle garra. Si te aflojás... mal, en el sentido de abandonarte, ¿no? Abandonar el momento.

Tocando en público hay distintos momentos. Hay momentos en donde estás luchando por concentrarte, momentos que son los mejores que es cuando estás consiguiendo la expresión, estás soltandote y de repente fluye, y estás como disfrutándolo a pleno. Creo que es como la mayoria, porque hay un disfrute en escuchar que suena bien.

En este fragmento el músico realiza una extensa descripción de su experiencia en la performance. Con respecto a lo Personal, describe una sensación de Cambio de rol. ${ }^{71}$ Narrar implica una cuestión de Expresión, pero también Determinar un Punto de vista (Propio) y un Acto de Fluir. Hemos considerado otros fragmentos de la entrevista

${ }^{71}$ El nodo Cambio de rol, pertenece a la categoría Dinámico, aunque se vincula directamente con la categoría Personal. 
para afirmar que este performer considera un involucramiento con el público (Narratario), un Compartir en el momento de la performance. ${ }^{72}$ Las sensaciones de Vértigo y Adrenalina, así como el Disfrutar se vinculan con la Indeterminación de lo que puede ocurrir si el músico se abandona.

El punto de vista descripto por este performer nos lleva a la narración de cuentos, y el rol del narrador en la narración que Jerome Bruner enunció de este modo: "un cuento refleja de algún modo el punto de vista o la perspectiva o el conocimiento de mundo del narrador, es más, su 'veracidad' u 'objetividad', o inclusive su 'integridad', algo que debe ser difícil de descubrir" (Bruner, 2002, p.34). ${ }^{73}$

\section{Discusión}

En este estudio de entrevistas nos propusimos acercarnos a la performance en términos de una narración. Las preguntas profundizaron sobre la actividad de los performers en lo referente a sus intencionalidades comunicativas, que habíamos interpretado en los resultados de la primera entrevista. En esta segunda entrevista, la interpretación de los resultados entiende a la comunicación performer-público de un modo análogo a la de un narrador y un narratario.

En primer lugar, lo comunicado en la performance es entendido como lo narrado. De este modo nos acercamos a la idea de una narración en la performance, en donde el músico puede realizar acciones sobre la obra, y determinar lo comunicado adoptando un rol de comunicador (qué comunica de la obra o cómo lo comunica). En segundo lugar, la comunicación de la música puede ser descripta de un modo análogo a enunciados verbales: maneras de decir, hablar desde el instrumento, dar cuenta de un mensaje, o literalmente narrar/contar.

Además surgen modos posibles de comunicación que pueden no seguir la lógica del emisor-receptor. Es posible entonces (volviendo a la discusión de la entrevista 1) que la comunicación que establece el performer no sea en una única dirección, o no requiera de un significado que deba ser entendido en los mismos términos que son enunciados por él. En este sentido, el significado puede ser el resultado de una interacción entre performer y el público, ser abierto a la significación personal o a un intercambio en la construcción colectiva: iniciar 'performances' de significados (Iser, 1978), iniciar y guiar una búsqueda de significados posibles (Bruner,

\footnotetext{
72 En otro fragmento de la entrevista, se refiere a la relación con el público tocando la Gran Obertura (Mauro Giuliani, op. 61): "Me ha pasado también, de tocar creo que me ha gustado más esto de compartir, está bien decir compartir, la música de uno ante gente 'no erudita'.

Me ha pasado tocar con gente que no conoce de música, la gran obertura y cuando así una catarata de notas con energía, y escuchar "haaaaaa" así, el público cerquita, unos muchachos que flashearon, y a mi me encanta. (ríe)"

${ }^{73}$ La traducción es de la edición en español (ver Referencias).
} 
1986).Las performances que inician los músicos también pueden ser entendidas como la búsqueda de significados posibles. De este modo la creación de lo narrado tiene lugar a partir de lo posible, dentro de una gama de indeterminaciones y posibilidades que surgen en la preparación de la obra, o que ocurren en la performance de acuerdo al contexto y los estados internos de los performers. Las acciones que describen los músicos en la construcción de la obra (en el ensayo o la performance) pueden ser consideradas en términos de una creación, lo que de un modo análogo se entiende como una narración.

Algunos aspectos de la obra que en la interpretación son indeterminados, o que dependen de situaciones de tipo dinámicas (que varían en el tiempo) permiten que el performer pueda construir o crear una segunda entidad a partir de la partitura de la obra. Entendiendo que la narración es una construcción temporal para contar una historia, el músico podría ser un narrador de la construcción temporal para dar vida, decir, recrear o reinterpretar la obra musical a su modo. Al apropiarse de la obra para interpretarla de un modo personal, lo indeterminado da cuenta de la ocurrencia de una búsqueda y la construcción en base a una serie de elecciones, decisiones o determinaciones sobre la obra en sus propios términos.

La música instrumental no puede narrar algo que pueda describirse con palabras, del mismo modo que el 'lenguaje' musical no puede narrar como lo hace el lenguaje verbal. Al preguntarles a los músicos qué se comunica en la performance, recibimos respuestas acerca de la expresión, la emoción, el afecto y lo sentido, entre otras. Si es esto lo que es posible de ser comunicado o narrado, debemos enfatizar el rol del performer como agente intencional humano.

S. Davies considera que la música no puede expresar emociones por sí misma, y que esto requiere de una atribución o intencionalidad humana: sólo las criaturas sensibles pueden tener y expresar emociones (S. Davies, 2011). Esta posición podría ser discutida. Por ejemplo, puede argumentarse que en la experiencia musical la relación con las emociones no es extrínseca, sino intrínseca: de este modo no percibimos las emociones en la música como algo inferido a partir de la percepción (Gomila, 2008). Sin embargo, la música también puede no ser pura forma: los significados y valores que puede adquirir dependen de su contexto pragmático, como actividad humana "su influencia depende del contexto social, así como de las intenciones con que se crea y se ejecuta, que, en contexto, le proporcionan un significado más allá de la pura forma" (Gomila, 2013, p. 414).

En esta tesis no solamente consideramos a la música como una actividad humana sino que además, desde el punto de vista del performer, nos posicionamos en su relevancia social, y en la instancia de la performance como una actividad 
compartida. De este modo, la intencionalidad del performer para atribuir (en relación a la obra, al compositor), construir (las propias) o generar emociones en contacto con el público es más que necesaria: se requiere de una persona que comunique (el performer) intencionalidades y de otra que perciba (infiera, atribuya) o las comparta.

Por último, la categoría Tiempo no logró constituirse en descripciones sustanciales acerca de la relación entre la música y el tiempo en la performance. Esto pudo deberse al modo en que los análisis de los datos fueron conducidos. A pesar de esto, consideramos que muchos de los datos que pueden describir esta categoría se vieron influenciados por la categoría Dinámico, una categoría que no había sido considerada de antemano, y que surgió de los datos para dar cuenta de procesos temporales analizados que ocurren en la relación del performer con la obra, en la preparación de la interpretación, y en su posterior performance. Por lo tanto, en la siguiente entrevista, nos proponemos profundizar en la relación entre el performer una única obra a lo largo varias performances en público. 


\section{ENTREVISTA 3}

\section{Objetivos}

Conocer la actividad del músico performer a lo largo de una serie de performances consecutivas de la misma obra. Profundizar en las descripciones de la actividad del performer sobre los aspectos dinámicos de su relación con la obra musical en la performance. Describir a la performance musical a través de la analogía del performer como narrador.

\section{Metodología}

\subsection{Participantes}

Participaron 4 músicos instrumentistas (1 pianista, 1 guitarrista, 2 cellistas; 2 mujeres, 2 hombres; edad promedio=38; desviación estándar= 13.39) con experiencia en la realización de performance solista (promedio $=18$ años) $)^{74}$. Los músicos convocados debían estar en actividad al momento de la entrevista, haber realizado varias performances de una misma obra musical durante un período mayor a un año, siendo la última presentación en público en un período menor a un año.

\subsection{Aparatos}

Las entrevistas fueron registradas y analizadas con los mismos aparatos que las entrevistas anteriores.

\subsection{Procedimiento}

Las entrevistas fueron realizadas de manera presencial, en un encuentro cara a cara con el investigador. Con un promedio individual de 54 minutos, se registraron 3 horas y 36 minutos ( $3 \mathrm{hs}$. $36 \mathrm{~ms}$.) en el total de las 4 entrevistas.

Cuando los músicos fueron convocados a la entrevista, se les dijo que la entrevista consistiría en una conversación acerca de una obra musical en particular. Se les solicitó que eligieran una obra que les gustara tocar, que hubieran tocado varias veces en público (sobre todo durante en el último año), y con la cual tuvieran un vínculo cercano, personal o de preferencia. Al comienzo de la entrevista, los músicos

\footnotetext{
${ }^{74}$ Una de ellos, la pianista, había participado en las entrevistas anteriores y fue invitada debido a que presentaba las características requeridas para el estudio.
} 
interpretaban la obra en presencia del investigador con el fin de recuperar aspectos que serían indagados en la entrevista. Las preguntas se realizaron en el marco de una conversación entre el investigador y el performer, de manera semi-estructurada.

\subsection{Guión de la entrevista}

La entrevista fue organizada en un guión que contenía preguntas que indagaban la relación entre el performer y la obra en diferentes momentos: desde el comienzo de su estudio hasta la actualidad, pasando por las diferentes instancias de performance en público..

\subsection{Análisis de los datos}

Se analizó el contenido total de las transcripciones para cada una de las 4 entrevistas. Para beneficiar la consideración de las temáticas abordadas, el texto de la entrevista fue separado de acuerdo a las temáticas de interés que guían las preguntas en el análisis; sin embargo, la información relevante no se encuentra contenida únicamente en cada uno de los fragmentos de texto seleccionados, sino que se distribuye a lo largo de todos ellos. En el Apéndice 3 se presentan los pasajes de la entrevista que serán descriptos en el análisis; la información se dispone de manera contínua para cada uno de los 4 casos, para facilitar su comprensión. Las temáticas son: (i) el vínculo con la obra; (ii) varias personas; (iii) la preparación de la obra; (iv) relaciones entre performances; (v) aspectos personales, (vi) retomar la obra; (vii) indeterminación; (viii) relación dinámica con la obra; y (ix) el público.

El análisis se ocupa de la síntesis de la información de acuerdo a las temáticas planteadas a partir del contenido de las entrevistas completas. ${ }^{75}$ El abordaje de la información se realiza sobre la base de las categorías y nodos obtenidos en el análisis de las dos entrevistas previas en relación a los temas de interés, indagando la información de un modo directo. Luego, se realizan comparaciones sobre los aspectos dinámicos y las concepciones obtenidas para cada uno de los 4 Casos y se consideran analogías entre música y narración.

\section{Resultados}

A continuación, los resultados del análisis serán desarrollados con respecto a: (i) la información obtenida en cada Caso, reducida y presentada de manera sintética manteniendo las expresiones originales de los performers; y (ii) las consideraciones

\footnotetext{
${ }^{75}$ Para entender aspectos particulares de cada síntesis en contexto, se recomienda leer los pasajes completos del Apéndice 3.
} 
que realizamos sobre los datos a través del uso de analogías entre narración y música.

\subsection{Las obras seleccionadas}

Los músicos seleccionaron una obra de su repertorio a partir de lo propuesto por el investigador. Se les dijo a los músicos que eligieran una obra con la cual tuvieran un vínculo personal o cercano, con la idea de poder obtener mayor información sobre una obra que hubiera sido transitada frecuentemente en el ensayo y en la performance en público. A continuación presentamos a cada una de ellas, con sus principales características compositivas, textuales y performativas.

Caso 1. Obra: Tocatta, Fugue, Allegro de Silvius Leopold Weiss.

Esta pieza fue compuesta originalmente para laúd Barroco en el año 1719, y su texto conocido fue escrito en una tablatura ${ }^{76}$ que pertenece al manuscrito del autor (no fue editada por el compositor). El repertorio académico de los guitarristas frecuentemente incluye obras de instrumentos pertenecientes a la misma familia de cuerdas, generalmente de épocas pasadas, que requieren de una adaptación cuando el registro, la cantidad de cuerdas, y la afinación del instrumento original difieren. El performer conoció la obra a partir de la grabación de un laudista argentino, transcribió y adaptó la música él mismo para poder tocarla en la guitarra. Tiempo después tuvo la oportunidad de tomar clases con dos laudistas (uno de ellos es el de la grabación mencionada), abordando entre otras la obra seleccionada.

Caso 2. Obra: Eusebius 1 de Gerardo Gandini.

En esta obra de música contemporánea pertenece a Eusebius, Cuatro nocturnos para piano o un nocturno para cuatro pianos (1984), donde Gerardo Gandini utiliza elementos de la pieza N ${ }^{\circ} 14$ del ciclo para piano Davidsbündlertänze (Danzas de la Liga de David, op.6) de Robert Schumann (1837). A través de procesos compositivos, los materiales son recontextualizados perdiendo su identidad original, y despojados de la estética de la que provienen, por lo que es difícil que sean fácilmente reconocidos. ${ }^{77}$ Cuando la performer trabajó sobre la obra, volvió en algunos momentos a tocar la obra original de Schumann. Lo que

\footnotetext{
${ }^{76}$ Esta escritura indica al músico dónde debe colocar los dedos, en lugar de representar los sonidos que surgirán. Debido a esto, éste tipo de notación se vincula de un modo más directo con las características del instrumento y su modo de ejecución (Martin, 2006).

77 Un análisis en detalle puede encontrarse en: Etkin, M., Cancián, G., Mastropietro, C. y Villanueva, M. C. (2001). Cita y ornamentación en la música de Gerardo Gandini. Revista del Instituto de Investigación Musicológica "Carlos Vega", 9, 35-56.
} 
aquí nos interesa es dar cuenta de la composición de la obra sobre (materiales de) una obra preexistente y la incidencia de los dos compositores en las palabras de la performer del Caso 2.

Caso 3. Obra: Preludio de la Suite para Cello \#1, de Johann Sebastian Bach.

Caso 4. Obra: Suite para Cello \#3, de Johann Sebastian Bach.

Estas obras elegidas por los cellistas pertenecen a un conjunto de 6 Suites para cello solo compuestas por Bach en el período entre 1717 y 1723 . La particularidad de estas piezas es que no se conoce su manuscrito original, existe un manuscrito de su segunda mujer, Anna Magdalena. Ambos cellistas que participan de la entrevista han abordado estas obras con cello moderno y cello Barroco -considerado éste último para realizar versiones que se acerquen al sonido original de la obra-, además de realizarlas con diferentes tipos de cuerda y arco. Los músicos destacaron que el texto no presenta demasiadas indicaciones para la interpretación, aunque existen sí ediciones posteriores y escuelas o tradiciones que establecen criterios para abordar estas músicas.

Las obras seleccionadas por los músicos entonces presentan estados intermedios entre el compositor y el intérprete. Exceptuando el segundo Caso, las obras pueden ser tocadas en instrumentos modernos que difieren del original; en el primer Caso la diferencia es aún mayor debido a las diferencias de cantidad de cuerdas y afinación. Por lo tanto, (i) en el primer Caso, el texto musical fue re-creado por el performer; (ii) en el segundo Caso, el compositor de la obra (Gandini) puede establecer cierto vínculo con el compositor anterior (Schumann); y (iii) en el tercer y cuarto Caso, el texto original jamás se conoció. Como veremos a continuación, estas particularidades de las obras influyeron en la formulación de las preguntas de la entrevista y, por lo tanto, en la información de las respuestas.

\subsection{Varias personas}

Originalmente pensadas para indagar la relación del performer con la obra, las obras seleccionadas por los entrevistados nos llevaron a preguntarles acerca de todas las personas que, según nos informaron, podrían estar involucradas con la preparación de la obra. Habiendo encontrado nuevos agentes vinculados a la obra, les preguntamos cuánto de cada uno había en su interpretación de la obra. La organización de la información se presenta en la Tabla 1; los datos se organizan para dar cuenta de las personas que median la relación entre el compositor y el performer, de acuerdo a diferentes instancias de incidencia sobre la obra. En el Caso 2 se incluye 
además una instancia previa a la composición de la obra, correspondiente a un compositor.

Tabla 1. Instancias de incidencia sobre la obra que median la relación entre el compositor y el performer..

\begin{tabular}{|c|c|c|c|c|}
\hline & Caso 1 & Caso 2 & Caso 3 & Caso 4 \\
\hline Anterior & - & Compositor & - & - \\
\hline Composición & Compositor & Compositor & Compositor & Compositor \\
\hline Transcripción & - & - & - & Transcriptores \\
\hline Texto & $\begin{array}{l}\text { Manuscrito, } \\
\text { Tablatura }\end{array}$ & Partitura & Manuscrito & Manuscrito \\
\hline Tradiciones & Laudistas & - & - & - \\
\hline Maestros & Profesores & - & - & Profesor, Maestro \\
\hline Grabaciones & Versión grabada & - & - & Versiones \\
\hline Adaptaciónes & Transcripción & - & - & - \\
\hline Performer & Performer & Performer & Performer & Performer \\
\hline TOTAL & 7 & 4 & 3 & 6 \\
\hline
\end{tabular}

\subsection{El vínculo entre el performer y la obra}

Inicialmente, la entrevista indagó a los performers acerca de los motivos de la elección de la obra y el tipo de vínculo que tenían con ésta. En la Tabla 2 presentamos un detalle organizado de la información. Hemos encontrado en los 4 entrevistados relaciones que caracterizan el vínculo con la obra a través del tiempo. En el Caso 1, es el tiempo compartido desde el trabajo previo en la re-composición de la obra, pasando por el ensayo y las performances; descripto como un "acompañamiento mutuo". La performer del Caso 2, vincula la obra a dos momentos importantes de su vida: la etapa de estudio de la obra junto su profesora y la actualidad, siendo la obra que eligió para volver a tocar en público. En el Caso 3, el performer se vincula a la obra a través del recuerdo de su maestro, así como también el de diferentes lugares y etapas de su vida. La conexión afectiva caracteriza el vínculo del Caso 4: desde la música del compositor con la cual conecta rápidamente, el armado personal de la obra y el recuerdo de su madre cuando la escuchaba en su casa. 
Tabla 2. Caracterización del vínculo con la obra para los 4 Casos. En las filas, se denomina a cada uno de ellos, se identifica un contenido particular y se detallan las personas involucradas.

\begin{tabular}{lcccc} 
& Caso 1 & Caso 2 & Caso 3 & Caso 4 \\
\cline { 2 - 5 } Denominación & Tiempo compartido & $\begin{array}{c}\text { Identificación } \\
\text { sonora }\end{array}$ & $\begin{array}{c}\text { Relación } \\
\text { temporales }\end{array}$ & Conexión afectiva \\
$\begin{array}{c}\text { Contenido } \\
\text { particular }\end{array}$ & $\begin{array}{c}\text { - Re-composición } \\
\text { de la obra, } \\
\text { - Acompañamiento } \\
\text { mutuo }\end{array}$ & $\begin{array}{c}\text { - Etapa 1: estudio } \\
\text { - Etapa 2: Volver } \\
\text { a tocar }\end{array}$ & $\begin{array}{c}\text { - Recuerdos de } \\
\text { lugares y etapas } \\
\text { de la vida }\end{array}$ & $\begin{array}{c}\text { - Armado personal } \\
\text { - Recuerdos }\end{array}$ \\
Personas & $\begin{array}{c}\text { Performer } \\
\text { Obra }\end{array}$ & $\begin{array}{c}\text { Los 2 } \\
\text { compositores } \\
\text { Profesora }\end{array}$ & Maestro & $\begin{array}{c}\text { Compositor } \\
\text { Madre } \\
\text { Performer }\end{array}$ \\
\hline
\end{tabular}

\subsection{La preparación de la obra}

Como hemos visto en los apartados anteriores, todos los músicos establecieron algún tipo de relación con otras personas en la preparación de la obra. El performer del Caso 1 tuvo la oportunidad de tomar clases y revisar su versión de la obra con dos laudistas (aquel que interpretó la versión grabada que transcribió y otro más), además de consultar con referentes de la interpretación en guitarra y revisar su propia performance a través de filmaciones (adoptando un rol de público). El Caso 2 había estudiado la obra con su profesora, mientras que mencionó también volver cada tanto a la interpretación de la obra original de Schumann. El cellista del Caso 3 trabajó la obra con su maestro en sus primeros años de estudio. En el Caso 4, la performer trabajó y analizó la obra con un profesor y también se hizo escuchar con un experto antes de la primera presentación.

\subsection{Relaciones entre performances}

Caso 1. Su interpretación de la obra es una base estable (parcial o final) que en los recitales sustenta una versión variable que se presenta al público. A medida que se realizan performances se re-ajustan detalles en la interpretación basados en lo que -el performer considera- no funciona; estos pequeños cambios además permiten una variedad en el tiempo que renuevan la tarea (es menos aburrido tocarla). Si tuviera que comparar la primera y la última, considera que la primera performance sería más esquemática, mientras que en la actualidad se vería a sí mismo tocándola más fluído, libre y convincente, transmitiendo confianza. 
Caso 2. Sobre la base de las mismas notas, cada versión es diferente y en cada una, la perfomer entra en un estado diferente, con la idea de que la obra siempre sorprenda. En un sentido personal, cada vez que la interpreta disfruta más la obra.

Caso 3. La obra tiene una profundidad que excede a las notas que la constituyen. Aunque la obra sea estudiada para que sea siempre igual, esto nunca ocurre, con cada interpretación cambia la comprensión de la obra. En la performance depende del contexto, por lo cual se considera que ésta es diferente y que el performer también es (se percibe así mismo como) diferente. La interpretación es definida (i) en las decisiones que el performer toma a partir del material cuando decide tocarla; (ii) en lo que el performer entiende de lo que está en el papel. Como algo que se encuentra entre la obra y la performance, la interpretación podría ser considerada como algo más.

Caso 4. A medida que se repite, la interpretación se va naturalizando y aparecen otras dificultades. Como resultado, la obra es resignificada por la performer cada vez que la toca, algo que nunca se termina.

Tabla 3. Aspectos estables, variables y procesuales identificados en las comparaciones entre performances que describieron los performers.

\begin{tabular}{lcccc}
\cline { 2 - 5 } & Caso 1 & Caso 2 & Caso 3 & Caso 4 \\
\hline $\begin{array}{l}\text { Elementos } \\
\text { estables }\end{array}$ & Interpretación & Texto & Interpretación & Interpretación \\
Variaciones & $\begin{array}{c}\text { Se ajustan } \\
\text { detalles }\end{array}$ & $\begin{array}{c}\text { El estado de la } \\
\text { performer }\end{array}$ & $\begin{array}{c}\text { El contexto de } \\
\text { la performance }\end{array}$ & $\begin{array}{c}\text { Trabajo de las } \\
\text { dificultades }\end{array}$ \\
$\begin{array}{l}\text { Proceso } \\
\text { Dinámico }\end{array}$ & $\begin{array}{c}\text { La performance se } \\
\text { dirige hacia algo } \\
\text { convincente }\end{array}$ & $\begin{array}{c}\text { Se encuentran } \\
\text { modos nuevos de } \\
\text { sorprender }\end{array}$ & $\begin{array}{c}\text { Cambia la } \\
\text { comprensión de } \\
\text { la obra }\end{array}$ & $\begin{array}{c}\text { La obra es } \\
\text { resignificada } \\
\text { cada vez }\end{array}$ \\
\hline
\end{tabular}

En la Tabla 3 se presenta la organización de la información a partir de la cual se identificamos elementos (i) estables y (ii) variables en la comparación de las performances, además de (iii) aspectos que se entienden en un proceso dinámico. En términos generales, cada performer describe las diferencias desde su experiencia, mientras que tres de ellos comparten a la interpretación de la obra como elemento estable.

\subsection{Aspectos personales}

Caso 1. Debido al trabajo de re-composición de la obra, la misma tiene una presencia personal significativa del performer. Es de las obras donde él siente que 
"más puede dar" y donde advierte que tiene buenas ideas. Las características distintivas de su trabajo las reconoce como propias y se distinguen al compararla con la versión transcripta (la versión grabada de Egüez).

Caso 2. La obra es una oportunidad para desarrollar los aspectos personales potentes de la interpretación al piano y sus intereses como intérprete. Por eso parte desde una identificación sonora con la obra y los compositores. La performance de la obra es el resultado de la interpretación de lo que Gandini quiso decir a través de Schumann. Con el tiempo, la performer afianza su modo de "sostener la obra" hasta que llega un momento en el que la hace propia.

Caso 3. Se posiciona en relación a la obra desde una versión historicista, que se acerca al sonido de la época. En este contexto, la parte escrita es una guía para la actividad del performer que tiene un rol creador. El aporte personal es desde su impronta, no desde la copia; también desde su forma particular de tocar, siempre desde un respeto al compositor: sin dejarlo de lado, es cien por ciento su impronta.

Caso 4. La performer eligió y armó la obra a su modo, desde su experiencia personal con ésta. Considera que está involucrada en la obra, en el juego, la búsqueda, en su modo de interpretarla, como sujeto creador.

Los aspectos personales involucrados en la performance pueden entenderse como análogos a los de un narrador. En el Caso 1, la re-composición de la obra en la adaptación del laúd a la guitarra implica algunas modificaciones con respecto al texto original; en este caso, la creación de una segunda entidad (relato) en relación a la obra compromete aspectos textuales y sonoros. En el Caso 2, lo que realiza la performer es entendido en términos de Apropiación de la obra, y surge de las oportunidades del texto para crear un desarrollo personal sonoro como el "sostén de la obra"; ésta narración es entendida como un acto en donde el performer sostiene o conduce la comunicación de la obra como si fuera suya; aquí, el narrador no es un vocero ficticio creado por el autor de la obra para pronunciar los signos (Bal, 1997), sino un agente autónomo (que no ha sido creado por el compositor) que narra en sus propios términos (sentido, punto de vista), a través de un trabajo de interpretación que le pertenece, conducido por sus propias acciones. En los Casos 3 y 4, la narración es entendida como una segunda entidad que surge a partir de un sujeto creador; en el Caso 3, el performer describe la impronta en la creación diferenciándola de una copia, mientras que en el Caso 4 la creación surge a partir de la experiencia personal con la obra. Por lo tanto, lo que consideramos aquí es que en todos los casos se reconocen acciones que dan surgimiento a una construcción o creación propia. 


\subsection{Retomar la obra}

Caso 1. La situación de tocar en público es descripta como la posibilidad de cómo se encuentra el performer con respecto a la obra. Luego de una performance, se retoma el trabajo técnico para realizar ajustes en la interpretación, partiendo del lugar en el que se la dejó. Estos detalles de la interpretación se trabajan a partir de grabaciones de audio o video, a través de la auto-observación del performer para identificar aspectos que debe estudiar. De este modo considera que cada nueva interpretación es una sobre-interpretación (la interpretación de la última interpretación). La obra también está mediada por cómo el performer está cada día, enfatizando así la relación directa entre interpretación y performer.

Caso 2. Al retomar la obra, la performer no arranca como si fuera la primera vez, se parte de una base que está afianzada.

Caso 3. Volver a la obra después de la performance puede ser motivo de una revisión de la interpretación, es lo que el performer intenta y considera que se debe hacer. Sin embargo no se arranca desde cero, se va construyendo, desde la seguridad de la interpretación propia.

Caso 4. Al retomar la obra se realiza una construcción sobre la anterior, se retoman cosas previas, se consideran cuáles pueden permanecer, y salen otras nuevas, no se arranca de cero.

Luego de la performance en público, todos los performers dijeron que, al retomar la obra, parten de una base previa, de una construcción, lo que anteriormente identificamos como los aspectos estables en la performance. Consideramos que esta construcción es algo que les pertenece, una creación que se toma para continuar en las siguientes performances. A diferencia de lo creado por el compositor, dicha construcción está informada por la situación de la performance de la obra en público, es decir: por la obra comunicada (narrada) ante el público por el mismo performer, a partir de la cual permite revisarla, o re-evaluarla. Por lo tanto, permite abordar a la obra desde sus características performáticas, lo que entendemos como su narración en acto. Esta narración no se corresponde directamente con el texto, es más una segunda entidad en relación a la obra (relato) que podemos entender, de un modo análogo, como el "texto" de la performance.

A partir de lo dado (la partitura) la construcción del performer puede ser considerada como algo propio: su visión de la obra. Esta interpretación construída se entiende como una versión que puede ser tomada por el performer para sus construcciones posteriores. En palabras de Bruner: "la construcción de mundos implica la transformación de los mundos y las versiones del mundo ya hechas." (Bruner, 1986, 
p. 97). En estos términos, si entendemos que lo creado por el performer es una narración de la obra, ésta narración se va construyendo sobre su narración previa cada vez.

\subsection{Indeterminación}

Caso 1. Lo que ocurre en la performance implica una auto-percepción del performer desde su inicio (la primera nota). Por lo tanto, es importante que el músico esté abierto a que durante su actuación ocurran cosas que no se pueden preveer.

Caso 2. En una performance puede ocurrir un hecho imprevisto, como la pérdida de la concentración. Sin embargo, aunque por un momento esto pueda ocurrir, la performer puede retomar la concentración y seguir con la obra. Un aspecto importante de la indeterminación que ocurre con los pianistas es que no suelen trasladar el instrumento a cada lugar que tocan (se utiliza el que está en la sala), lo que genera diferentes condiciones de respuesta del piano con respecto a las acciones de ejecución. Este aspecto, más la cercanía o lejanía del público puede implicar, por ejemplo, una decisión para cambiar el plan expresivo en el rango de las intensidades.

Caso 3. La interpretación de la obra de Bach es ambigua, y existen varias escuelas o corrientes diferentes. En una performance pueden producirse errores pero el performer continúa, depende del momento, de la situación, del músico y su preparación: el músico no siente siempre lo mismo y está constantemente cambiando. Para el cellista, la performance de la música clásica es algo que pasa en el momento, algo único.

Caso 4. El texto escrito no determina por sí solo las articulaciones necesarias para la interpretación, son sugerencias para tocarlo. Las diferentes vertientes y usos de los instrumentos presentan un panorama indeterminado: el cambio es grande. La peformer considera importante aceptar que no se tiene todo el control de lo que pasa el día de la performance, que algunas cosas suceden al azar.

En relación a la performance existen aspectos indeterminados que cumplen un rol importante para entender que el performer es quien determina lo narrado como un agente intencional. Esto puede ser posible debido a que: (i) el texto no determina todo lo que ocurre en la interpretación y puede presentar aspectos ambiguos; (ii) el texto tampoco puede determinar lo que ocurre en la performance in situ; (iii) el contexto donde se lleva a cabo la performance implica un lugar, un instrumento y un público que influyen en ella; (iv) el performer está abierto a lo que pueda suceder (imprevistos, errores) para tomarlo como parte de la performance y continuar con la acción; (v) la auto-percepción del performer (sus estados, motivaciones y metas) influye en la realización y el resultado de la performance. Por lo tanto, el performer toma una serie 
de decisiones previas, además de otras que ocurren en el momento para determinar cómo se lleva a cabo la performance. Estas decisiones no están escritas de antemano en el texto de la obra pero son parte del acto narrativo en tanto toma de decisiones en curso que realiza un agente: el narrador.

\subsection{La relación dinámica con la obra}

Caso 1. El proceso de compartir tiempo con la obra ${ }^{78}$ es planteado como un proyecto personal de aprendizaje, y surge como una recomendación que el performer se hizo a sí mismo. En ese tiempo, hay mucho para "discutir" con la obra, en el sentido que hay una mirada del performer hacia la obra que varía desde la primera vez a la última, mediada por la situación en vivo, donde se contraponen el yo teórico (del ensayo) y el yo práctico (de la performance). Esto modifica lo que el performer piensa de la obra, sin embargo la obra no cambia: el que cambia es el performer.

Caso 2. La vinculación a través del tiempo con la obra es definida literalmente como una relación. La obra nunca es vista de la misma manera, siempre se encuentran cosas nuevas, hay una maduración. Para la performer una obra siempre modifica al performer. Juntas -obra y performer- fueron transformándose: la segunda se apropió de la primera, la sintió como propia y le realizó aportes. En este sentido entendemos que hay una relación de transformación mutua.

Caso 3. Con el paso del tiempo, el performer va conociendo cada vez más a la obra, encuentra cosas nuevas, nuevos sentidos. La interpretación de la obra va profundizándose, cambiando; el músico se propone una búsqueda, nuevas metas, otras expectativas. El performer está constantemente cambiando (creciendo, madurando), la interpretación representa cómo se siente y se conecta con la obra en cada momento o etapa; sin embargo, el performer cambia en relación a transitar por un conjunto de obras, no por una sola. La obra no se modifica, sin embargo cambia la perspectiva histórica que se tiene de ella; el performer enfatiza que la música no es solamente lo que está en el papel: es lo que cada uno puede aportar, hacer y transmitir a partir de eso.

Caso 4. La relación con la obra a través del tiempo es diferente debido a que ella misma (la performer) es diferente. Si bien al tocarla cada vez la obra se resignifica, considera también que la obra madura en su psiquis cuando no la está tocando. A pesar de ésta maduración, dice que la obra como entidad no cambia; en su lugar, la obra modifica al performer.

\footnotetext{
${ }^{78}$ Esto no es un término analítico nuestro, el músico lo dijo con sus propias palabras: "yo cuando hablo de una música o cuando me recomiendo a mí mismo 'voy a empezar a estudiar ésta música' lo pienso como 'a ver, con ésta música yo voy a compartir mucho tiempo'.
} 
Tabla 3. Aspectos dinámicos de la relación en el tiempo, en la obra y en el performer.

\begin{tabular}{|c|c|c|c|c|}
\hline & Caso 1 & Caso 2 & Caso 3 & Caso 4 \\
\hline En el tiempo & $\begin{array}{c}\text { Hay una } \\
\text { discusión con la } \\
\text { obra. }\end{array}$ & $\begin{array}{l}\text { Hay una } \\
\text { maduración. }\end{array}$ & $\begin{array}{c}\text { Se profundiza. } \\
\text { Cambian las } \\
\text { expectativas. }\end{array}$ & $\begin{array}{l}\text { La relación se } \\
\text { modifica. }\end{array}$ \\
\hline En la obra & $\begin{array}{c}\text { La obra no } \\
\text { cambia. } \\
\text { Cambia la } \\
\text { mirada hacia la } \\
\text { obra. }\end{array}$ & $\begin{array}{c}\text { Cambia la visión } \\
\text { de la obra. Se } \\
\text { encuentran } \\
\text { cosas nuevas. } \\
\text { El intérprete } \\
\text { transforma a la } \\
\text { obra. }\end{array}$ & $\begin{array}{l}\text { La obra no se } \\
\text { modifica. } \\
\text { Se encuentran } \\
\text { cosas nuevas. } \\
\text { Se la conoce } \\
\text { más. }\end{array}$ & $\begin{array}{c}\text { La obra no se } \\
\text { modifica. } \\
\text { Se resignifica } \\
\text { cada vez que se } \\
\text { toca. }\end{array}$ \\
\hline En el performer & $\begin{array}{l}\text { La obra modifica } \\
\text { al intérprete }\end{array}$ & $\begin{array}{l}\text { La obra modifica } \\
\text { y transforma al } \\
\text { intérprete }\end{array}$ & $\begin{array}{c}\text { La maduración } \\
\text { se produce con } \\
\text { el conjunto de } \\
\text { obras }\end{array}$ & $\begin{array}{l}\text { La obra modifica } \\
\text { al intérprete }\end{array}$ \\
\hline
\end{tabular}

En todos los Casos la obra modifica al performer debido a la relación que se establece a lo largo del tiempo. En esa relación, los performers se modifican debido a un cambio de visión, una resignificación o un mayor conocimiento de la obra. Excepto el Caso 2, donde la performer dice que el intérprete transforma la obra (en el sentido semiótico de una construcción textual), en los demás la obra no cambia.

Según la distinción literaria entre historia y relato, éste último se entiende como la manera de contar la historia; sin embargo, al contar la historia, ésta no se modifica. En la analogía de la narración de la obra musical, el texto puede constituirse como la entidad que no se modifica. La consideración de una historia en la música ha sido criticada desde una perspectiva verbal de la narración (la música no puede contar una historia); sin embargo, la obra podría ser análoga a la historia en el sentido en que lo narrado no la modifica. De la misma manera que los sucesos de un cuento no son modificados al narrarlo de diferentes maneras, la obra musical no se modifica por la narración del performer. Desde la mirada del performer, la posibilidad de la obra para ser narrada se constituye al entender que hay más de una manera de interpretarla.

\subsection{El público}

Caso 1. Realiza toma de decisiones en relación al público que está del otro lado: en relación a qué de toda la información de la obra es lo más importante para transmitir al oyente. Estas determinaciones son re-adaptaciones de la interpretación en vivo, que se deciden en el momento de acuerdo a la situación, que incluye el estado en que el performer se encuentra ese día. 
Caso 2. La relación con el público en la performance se describe como la acción del performer para hacer vibrar al otro con el sonido que regresa en el mismo sentido. Los comentarios recibidos luego de una performance son considerados como parte de la relación entre la performer y la obra.

Caso 3. Cuando toca está mostrando lo que siente y entiende de lo que está en el papel. Las mejores experiencias de la performance de la obra son aquellas en las que había conexión y buen clima, en las que sintió la atención y la energía para escuchar, en las que estaba llegando lo que hacía. Cuando tiene una buena experiencia trata de recordar lo que ocurrió para que pase nuevamente, considera que la música es un vehículo emocional para llegar a la gente, y que esas emociones se vinculan con los recuerdos de las personas.

Caso 4. La performer cuenta que siempre que toca la obra primero habla y explica acerca del autor, de la suite, del contrapunto, para naturalizar la instancia de la audición, introducir la obra y acercarse al público. Luego, al comenzar la performance dice que trata de armar un personaje, una construcción propia en el pensamiento y en lo emocional, según lo que la música le sugiere. Dicha construcción es algo que cobra sentido únicamente en relación al público que lo completa.

En el Caso 1, la narración se realiza como un acto de mostrar, en la que el creador de la narración elige revelar algunos eventos seleccionados, mientras que por el otro lado oculta otros (Cobley, 2001).

Con respecto al Caso 2, entendemos que hacer vibrar al otro es generar una llegada desde el sonido, mover al otro o provocarle algo a través de la acción. La fenomenología de la performer en relación al sonido del instrumento puede involucrar: por un lado, que la energía implicada por ésta para la producción sonora sea percibida como una devolución del instrumento hacia ella (sensación física o táctil de la unidad performer/instrumento); por el otro, una parte de la energía implicada se transforma en energía sonora que repercute en el entorno, el músico anima el espacio a su alrededor al empujar hacia afuera su energía (Burrows, 1987; Tanco, 2013b). En este sentido, el narratario es convocado a participar en la narración a través de la energía sonora que lo hace vibrar, mientras que la performer percibe la devolución de esa energía como algo que llega desde el público.

La narración a través de la emoción puede caracterizar la descripción del Caso 3. Como vimos anteriormente, el performer se vincula con la obra a través de recuerdos de lugares y personas. La relación entre la memoria y la emoción puede ser de dos tipos: (i) la memoria es acerca de una emoción pasada, o (ii) la memoria puede causar una emoción presente (Debus, 2007). Se considera que la música participa en 
la construcción de la memoria al ser experimentada de un modo dinámico; es por esto que a través de evocar y reproducir la estructura temporal de una situación, podemos recuperar el contexto, el recuerdo de un ser querido, un sentimiento, una situación, un modo de ser (DeNora, 2000). De este modo, la narración de la obra puede tanto evocar una emoción vivida con respecto a ella o causar una emoción en el presente, en el público, en el performer o en ambos.

Con respecto al Caso 4, Almén (2008) desarrolla un argumento similar siguiendo a Genette (1972) en la distinción entre escena y resumen, una estrategia frecuente en las obras de teatro. Mientras que en la escena se realiza una presentación directa con respecto a las palabras y acciones de los personajes, en el resumen el narrador describe o relata lo ocurrido. Almén sostiene que se podría argumentar que el narrrador se encuentra presente cuando la acción continúa (Almén, 2008). En el Caso 4, la performer cumple estos dos roles: primero introduce el resumen y luego realiza la actuación.

\section{Discusión}

Hemos visto que el vínculo del performer con la obra es dinámico en el sentido que se modifica con el tiempo. En esta relación la obra no se modifica, el que se modifica es el performer y su visión o comprensión de la obra. Si la obra no se modifica, entonces podemos considerarla en términos análogos a la historia de una narración: un cuento puede ser narrado de una manera diferente pero eso no implica modificar la historia. Sin embargo, esta analogía no supone decir que la música tenga una historia.

Nosotros entendemos que lo que el performer realiza es una construcción que considera como propia, una interpretación o versión (narración) sobre una entidad que no se modifica (la obra). Esta segunda creación propia del performer surge (i) de la indeterminación del texto musical (el texto no puede contener todo lo que ocurre en la performance, brindando posibilidades de significado y la toma de decisiones (ii) de la indeterminación en la situación de la performance, que es compartida por el público y el performer: cada acción u ocurrencia in situ crea nuevas expectativas en el momento, renovando el interés de ambos.

Al volver a la obra, se parte de la base existente mediada o influenciada por la situación de la performance en público. Entendemos que esta construcción se realiza sobre una construcción previa existente (Bruner, 1986), lo que en términos análogos entendemos como la narración de la narración.

Sin embargo, la analogía obra/performance en relación a historia/relato de la narración literaria podría ser problemática con respecto al lugar del texto: mientras que 
en la literatura el texto se correspondería con el relato, en la narración musical que proponemos el texto se encuentra en el lugar de la historia.

Podríamos entonces volver al concepto de narrativización de Fludernik (2003) mencionado en el Capítulo 3, un proceso dinámico mediante el cual un lector puede asignar una propiedad narrativa a un texto o discurso para entenderlo (por ejemplo, asignarle una serie de eventos). De este modo, narrativizar es un acto que permite entender a un texto -e incluso a un objeto- de un modo narrativo; esto no implica necesariamente que el texto sea en sí mismo narrativo, sino que debe tener ciertas cualidades, una potencialidad narrativa que invite al lector u observador a considerarlo como narrativo (Fluderkin, 2003). En el caso del performer, entonces, considerar al texto como una historia que pueda ser narrada implica narrativizar la partitura. 
PARTE 3

Conclusiones 


\section{CONCLUSIONES}

En esta tesis nos propusimos indagar en la actividad del performer a través de la analogía del narrador. Para esto, abordamos a la performance clásica en un contexto de relaciones sociales que el performer establece con diferentes personas, desde las primeras instancias de su estudio del instrumento hasta las instancias de presentación en público. La planificación metodológica buscó acercarse al punto de vista del performer para obtener sus descripciones de la experiencia informadas por la práctica.

Nuestro estudio se inició a partir de una hipótesis que previamente había sido abordada por investigadores acerca de la relación entre narrativa y música: que la música es narrativa, que es posible postular una narrativa musical, o que existen aspectos análogos entre la música y la narrativa. Estos abordajes plantearon una relación entre el análisis de la Narratología y el análisis de los textos musicales que no intentó ser estudiada en esta tesis. En su lugar, dicha relación análoga se enfocó en estudio de la performance de una obra entendida como la narración de una historia.

La segunda hipótesis, derivada de la performance como narración, también se sustentó en algunos enfoques anteriores que postularon que la relación puede ser abordada a través de la analogía del performer como un narrador. Al tomar estas ideas como punto de partida nos propusimos indagar dicha hipótesis en la búsqueda de lo narrado, entendiendo que una narración depende del punto de vista, perspectiva o el conocimiento del mundo de un narrador (Bruner, 2002). Por lo tanto, consideramos que para postular al performer como un narrador su perspectiva debía ser tenida en cuenta, algo que dificilmente resulta posible desde la única mirada del investigador, razón por la cual nos comprometimos con una investigación que considerara el punto de vista del performer.

La tercera hipótesis se propuso abordar la actividad del performer como el resultado de interacciones de tipo social que éste establece para dar sentido a la obra. Por ello, la hipótesis fue enunciada como un vínculo entre el performer y la obra, entendiendo que en su actividad el músico se involucra personalmente con la música que está produciendo y que la performance no es el resultado de una actividad individual sino colectiva. En este sentido, el significado de la música no es determinado por una única persona.

A través de las palabras de los músicos, hemos realizado una interpretación de la información que nos permitió pensar a la performance en relación a (i) situaciones interactivas de la vida social, (ii) instancias de comunicación y (iii) narraciones. Lo que 
presentamos a continuación es una síntesis y reflexión del recorrido realizado en esta investigación en forma de conclusiones. Con estas palabras, no pretendemos afirmar que esto es así, o generalizar acerca de la práctica de los performers; en su lugar, consideramos que nuestras conclusiones -basadas en el análisis de la información recabada con un grupo de performers en un contexto dado- pueden aportar al conocimiento de la música en el sentido de ofrecer un modo particular de comprensión acerca de la performance musical como actividad humana.

\section{La interpretación de la partitura en un contexto de intencionalidades}

La actividad del performer requiere producir la presentación de obras musicales frente al público, una actividad que se inserta en convenciones y validaciones sociales dentro de la práctica musical occidental. Hemos visto que en la preparación de la obra la construcción del significado que el performer realiza es consensuada en relación a otros agentes sociales reales: profesores, maestros, expertos, colegas, allegados. Cuando estos no están disponibles, el performer puede convocarlos o evocarlos para ayudarse a entender la obra interactuando con un agente virtual. Por otro lado, el proceso de lectura y comprensión de la partitura implica establecer una interacción con ésta o con la obra: encuentros, diálogos, discusiones, convivencias, etc.: formas de vincularse que recrean interacciones de la vida social.

Aunque el compositor no esté disponible, el músico requiere convocarlo como un interlocutor válido, que pueda entender a la obra y a la interpretación de ésta de un modo similar. Esto implica una negociación o co-construcción de la performance a través de las intencionalidades de ambos, de manera de guiar las acciones y la toma de decisiones que son necesarias para llevar a cabo la tarea. Otras fuentes de información, como las performances que se han realizado anteriormente -y son aceptadas como válidas dentro de la práctica musical- sirven al músico para entender a la obra de un modo intencional a través de un agente equivalente en su rol y función dentro de la misma práctica.

También hemos visto que los performers suelen describir una interacción con la partitura en términos de relaciones sociales. Por ejemplo, un diálogo con la partitura es descripto en relación a un ida y vuelta que produce una actualización de la música en el performer; a partir del primer encuentro con la partitura, su comprensión avanza en el tiempo en el sentido de un significado: no implica meramente un significado de la obra, sino un significado en acción y sonido. Mientras que el texto siempre permanece igual, el performer inicia una búsqueda de significados posibles (Bruner, 1986); o bien, es la indeterminación del texto la que permite un espectro de actualizaciones: el texto 
se comunica con el lector y lo invita a participar en la producción de la comprensión de su intención (Iser, 1978).

Además, los músicos realizaron descripciones acerca de interacciones con la obra: convivir, compartir tiempo, escuchar lo que la obra "te va diciendo". Popova (2015) sostiene que cuando leemos un libro co-construímos una consciencia narrante que estructura los eventos hacia la meta del narrador; al hacerlo, enactuamos intencionalidades: "nos convertimos en participantes dispuestos en sus mundos, pero también ellos se convierten en parte del nuestro." (p. 76). En el caso del performer, enactuar no es meramente un acto mental para atribuir intencionalidad; es un re-crear (una situación, un momento, o un acto) para entender la música, lo que lo involucra en una participación activa que realiza a través de la producción de la obra para hacer sentido. Esta enacción puede producirse durante la preparación de la obra, desde el primer contacto con la partitura; la obra surge entonces como una intencionalidad musical co-construída.

Por todo esto, concluimos que el performer entiende a la obra como un acto intencional humano. No sólo requiere que el performer sepa leer y tocar la partitura adecuadamente, comprender los procesos composicionales de la obra o las estructuras sobre las que se construye semánticamente. Para llevarlas a cabo, requiere de una participación activa para hacer sentido del texto escrito; de una acción del performer que se basa en construcciones sociales previas a las que accede interactuando con agentes (reales o virtuales) y reinterpretando la obra desde su propia intención.

En esta significación social de la música, concluimos que la interpretación de la partitura se realiza de un modo análogo a la comprensión de la lectura narrativa, en el sentido en que es propuesto en el campo de la cognición social (Popova, 2015). El performer, en tanto lector musical, no accede al significado de la obra únicamente a través de los signos escritos, sino a través de una construcción que realiza al iniciar una búsqueda de significados dentro de una variedad de significados sociales posibles, a los que accede interactuando con personas reales o virtuales (evocadas, imaginadas o personificadas) en instancias psicológicamente reales.

Ahora bien, desde la analogía propuesta, nosotros no entendemos que la música sea narrativa. Nuestro abordaje en cambio intenta dar cuenta de que la narración permite hacer sentido de la obra musical. La narrativa, entendida desde la cognición social, hace posible el conocimiento, y junto con la analogía o la metáfora constituyen dos caminos para estructurarlo; las narrativas son procesos dinámicos, la estructura de la acción "refleja los lazos espacio/temporales y relacionales causales de los eventos que involucran agentes humanos" (Popova, 2015, p.2). Cuando nosotros 
decimos que el performer es un lector musical, inferimos que puede narrativizar la partitura, como un recurso que asigna una propiedad narrativa a un texto para entenderlo (Fludernik, 2003).

Lo que Popova (2015) postula es que entendemos a las narrativas de un modo similar a como entendemos a las personas, y que las historias son comprendendidas en relación a los procesos de interacción que moldean un lector y un narrador. Lo que nosotros consideramos importante aquí es destacar dos aspectos importantes de la consideración del performer como lector musical: por un lado, que puede proceder como un co-constructor, receptor o narratario de la obra para entenderla; por el otro, que esta posición adoptada es lo que le permite luego entenderse y comunicarse para empatizar con el público, adoptando una posición de narrador.

\section{La comunicación en la performance}

En este estudio hemos enfatizado los aspectos comunicativos de la intencionalidad del performer. Las descripciones nos permitieron entender que el músico se encuentra en una posición intermedia entre la composición de la obra y su performance. Mientras que la primera supone la comunicación con el compositor, la segunda implica una relación con el público. Sin embargo, en esta dualidad también hemos visto que el performer puede comunicarse consigo mismo: es al mismo tiempo quien produce la música y quien la escucha. Esta posición permite al performer valerse de su rol de "oyente" para realizar atribuciones de intencionalidades con respecto a las expectativas del público porque, a pesar de producir la música, en la performance también se involucra con ésta desde un lugar de receptor.

El modelo de performance del repertorio musical académico que estudiamos aquí no permite una interacción directa entre el público y el performer, como ocurre en otro tipo de performances no-académicas. A partir del análisis de las entrevistas con los performers hemos considerado sus descripciones de la comunicación en diferentes direcciones: desde él, hacia él, consigo mismo y como reciprocidad. Además, la comunicación fue también descripta en términos de interacciones sociales: encuentros, diálogos, mensajes, enunciados. Entendemos que este tipo de comunicaciones musicales no se sostienen (ni tampoco se explican) a través del significado del lenguaje verbal: sino en actos de sonido y movimiento que se ponen en juego para compartir la música sobre una base proto-narrativa (Imberty, 1997; Español, 2014). El performer puede percibir a las personas del público aunque no los esté mirando o escuchando; esta experiencia es descripta como una presencia o compañía que le permite involucrarse más en la performance de la música; en este 
sentido, de acuerdo a lo descripto por los performers, la presencia de un otro podría no ser una actividad imaginativa, sino sentida. El performer además experimenta un cambio en la auto-percepción del yo en presencia del público, lo que puede ser entendido como regulaciones intersubjetivas que se establecen en una comunicación empática durante la performance (Martínez, y Pereira Ghiena, 2015).

La comunicación con la música produce una experiencia afectiva, emocional y sentida en el performer. Esta experiencia ocurre tanto en la comunicación con el público como cuando dice que se comunica consigo mismo, pudiendo además establecer un vínculo con el compositor, la obra y otras personas en términos similares. Algunos músicos contaron que cuando están tocando tienen una percepción o presunción de que el público está sintiendo o experimentando un afecto similar; esto se sustenta en aspectos compartidos de la experiencia humana que se ponen en juego a través de la música. Los performers además hablaron acerca de la presencia del compositor en la interpretación que construyen sobre la obra. En este sentido, a partir de la incorporación de las intencionalidades atribuidas al compositor, el performer podría estar brindando indicios que dan lugar a la presunción de su presencia.

En las conclusiones de la Entrevista 1 hemos encontrado que el performer no se implica únicamente en el modelo de la comunicación tradicionalmente entendido en el sentido compositor $\rightarrow$ performer $\rightarrow$ público.

En la interacción virtual con la partitura o la obra, la comunicación con el compositor es descripta en varios sentidos, puede ser:

$$
\text { compositor } \rightarrow \text { performer ; performer } \rightarrow \text { compositor; y performer } \leftrightarrow \text { compositor }
$$

En la performance, hemos visto que la comunicación con el público se presenta en las mismas direcciones:

$$
\text { performer } \rightarrow \text { público ; público } \rightarrow \text { performer; y performer } \leftrightarrow \text { público. }
$$

Del mismo modo, éstas direcciones se describieron en relación entidades o interlocutores virtuales como la obra y la partitura, mientras que en el caso del performer consigo mismo la dirección es:

$$
\text { performer } \leftrightarrow \text { performer. }
$$

Además, estas pueden ser descriptas como ocurriendo de manera simultánea; por ejemplo, cuando los músicos dijeron que pueden estar tocando para sí mismos y para los demás:

$$
\text { performer } \leftrightarrow \text { performer } \rightarrow \text { público. }
$$


Es por esto que, desde la experiencia del performer, cuestionamos la direccionalidad del modelo de comunicación tradicional de una única vía y un único sentido. El modelo parece ser más complejo, es más una red de comunicaciones que pueden ocurrir de manera simultánea a través de la música, y para esto el performer se encuentra en un lugar privilegiado: su rol de mediador no implica transmitir un mensaje sin intervenir o interponerse; por el contrario, puede ser considerado como el centro de la comunicación. Por lo tanto, concluimos que el performer experimenta la comunicación en diferentes direcciones, y esto es fundamental para entender a la performance como una práctica social de hacer sentido.

Con respecto al rol del performer como mediador entre la obra y el público entendemos -en vista de los hallazgos de este estudio- que, en su lugar, es la performance el medio para la comunicación entre el performer y el público. Esto implica, además de la significación del "mundo" de la obra, una significación de la situación que se establece con otros en el contexto de un evento que, decimos, es extrínseca a la composición de la obra. Esto plantea una diferencia entre el compositor y el performer en relación a las intencionalidades que son puestas en juego para la comunicación de la obra.

Al abordar la relación entre la narración y música nos enfocamos en la comunicación que tiene lugar en la performance, en lugar de entenderla a partir de las categorías de la narrativa literaria y sus recursos verbales. La base común existente entre música y narración permitiría basar las relaciones análogas en proto categorías, como la proto-narración, que se encuentran en los primeros intercambios de la infancia temprana (Imberty, 1997). La música como medio expresivo culturalmente organizado forma parte de las interacciones en etapas anteriores a la adquisición del lenguaje y puede permitir entender la composicionalidad de la comunicación adulto-bebé en la identificación de construcciones narrativas (Martínez, 2007). Consideramos que a través de esta base común -y no la del lenguaje- es que se pueden establecer mejores relaciones análogas en el sentido inverso: desde la narración hacia la música.

De esta manera, decir que la música no puede significar o establecer relaciones semánticas del modo en que lo hace el lenguaje no implica descartar que en una performance haya (i) una comunicación de un mensaje (Rink, 1994); (ii) que el performer pueda 'colorear' de subjetividad la partitura dando surgimiento a una narrativa en cada focalización (Meelberg, 2006); (iii) que la performance sea entendida como una experiencia intersubjetiva (Shifres, 2007); (iv) que los gestos musicales sean entendidos como enunciados de personas, como formas de hablar y manipular el tiempo a la manera de una voz narradora (Abbate, 1991); o (v) que una serie de 
eventos puedan ser entendidos como acciones o comportamientos que se atribuyen a acciones humanas de un agente de la acción narrada (Maus, 1991).

\section{Acerca de la relación entre narrativa y música}

Nuestro enfoque acerca de la analogía entre la narrativa y la música se centró principalmente en establecer relaciones entre el acto de la narración y la performance musical, recuperando categorías de la Narratología que se refieren a agentes humanos (narrador, focalizador, voz narradora, personaje). Al posicionarnos en dicho enfoque consideramos que para el estudio de la performance, la relación análoga entre los textos literarios y musicales no era adecuada en vistas de un fenómeno que excede lo que está escrito en la partitura. De esta manera, intentamos evitar la aplicación forzada de categorías que, entendemos, se refieren a aspectos y recursos textuales o composicionales sobre los que el performer de una performance clásica no incide de manera directa.

En cuanto a la comunicación de la obra musical, hemos considerado que los performers pueden cumplir un rol de narrador en relación a un narratario cuando tienen intenciones específicas, vínculos e intercambios con el público que determinan en alguna medida el curso de las acciones en la performance, o cuando consideran que lo comunicado les pertenece en cierto modo a todos los que participan del evento. Los performers pueden tomar decisiones a partir de las indeterminaciones de la partitura o de circunstancias no planificadas en el curso de la performance; dichas acciones les otorgan un sentido de agencia que los posicionan como sujetos creadores en la determinación de lo comunicado en la performance. Además, la determinación puede implicar comunicar el punto de vista del performer en relación a la obra, o ser éste quien se encarga de llevar a cabo una narración, al convencer, provocar o dar sentido a la composición de un modo análogo al narrador. Los aspectos personales que afirman su rol comunicativo pueden ser entendidos en términos de un focalizador, involucrando su intencionalidad, su carácter, su subjetividad, su sentido del yo o personalidad, su convicción y el compromiso, que lo posicionan en relación a la presentación personal de la obra.

Algunos músicos entrevistados dieron cuenta de la importancia de que la performance sea convincente, algo que desde la perspectiva del espectador produce un acuerdo o empatía con el performer. Esta determinación que el músico tiene cuando realiza la performance puede ser posible a través de la modalidad narrativa del pensamiento, que permite producir relatos que convencen por su semejanza con la vida o una verosimilitud, además del modo subjuntivo de organizar la realidad, que 
permite estar intercambiando posibilidades humanas y no certidumbres establecidas (Bruner, 1986).

En las palabras de los músicos la comunicación fue descripta también como enunciados: al decir, contar, narrar, transmitir un mensaje o discurso, y al hablar con el instrumento. Estas descripciones, que entendemos en el sentido de una voz narradora, son las que según Abatte (1991) nos permiten abordar la narrativa sin entenderla exclusivamente como un asunto de la historia, y que además permiten descentrar la idea de voz como un asunto exclusivo del compositor.

También hemos encontrado descripciones acerca de la performance como un acto que se realiza a través de acciones y gestos exhibidos. Los performers pueden también describir acciones que se entienden en un sentido de creación: dar vida, construir, transformar, formar, modificar, recrear, proyectar, llevar, fluir, inventar o jugar, experimentar una situación mágica o irreal, o situar a la performance en otro lugar o mundo. Aquí entendemos que la creación del performer es algo que se construye a partir de lo posible, mundos y significados que se sustentan en una base social de entendimiento al ser constantemente interpretados y negociados por sus integrantes. En las entrevistas hemos identificado descripciones de la acción en la performance como transformaciones, versiones y recreaciones que puede relacionarse con las construcciones de mundos y significados desarrolladas por el constructivismo y la psicología social (Goodman, 1984; Bruner, 1986).

Cuando les preguntamos a los performers en dónde estaban cuando estaban tocando, varios de ellos dijeron estar en otro lugar, otro mundo, otra dimensión; además mencionaron de un modo similar situaciones irreales o mágicas. Sin embargo, no interpretamos estas palabras en el sentido de sacrificar por un instante "nuestra limitada existencia individual en aras de una especie de existencia superior". (Moritz, en Dahlhaus, 1978, p. 8), como se entiende a la relación entre el sujeto y el objeto en la idea de la música absoluta. Entendemos a estas descripciones como aspectos análogos a la narración en un contexto de relaciones humanas, donde el narrador invita a compartir un mundo (erase una vez, hace mucho tiempo, en un lugar muy lejano...), a compartir una música de otro tiempo, a transportar al oyente a un plano diferente (Rink, 1999), a compartir un estado afectivo de la mano del músico. Cuando los performers dicen que han conversado con un compositor, o que el compositor puede estar en la sala, cuando dicen que están en otro mundo, cuando dicen que en la performance hay algo del compositor, algo de ellos, y algo que es del público, se trata de construir lo posible en la música. Es a través de la música, de la obra y la performance que estos mundos construidos son posibles, aunque no sean reales. 


\section{Acerca de lo narrado}

En esta tesis partimos de las concepciones acerca de la obra musical: su definición en relación a su autonomía, su consideración como expresión del compositor, y su objetivación en la partitura. También hemos revisado concepciones que la definen como un objeto intencional, y la distinción entre producto y proceso en relación a una serie de estados de la obra.

En la música actual, varios aspectos de la performance musical occidental se mantienen, mientras que otros han sido modificados. Desde su origen histórico, debido a la ausencia del compositor y a la perspectiva histórica/cultural de las obras, la práctica de la performance occidental fue adaptándose a las condiciones de cada época siguiendo el cánon a través de generaciones de músicos. En el siglo pasado, los movimientos de las performances históricas o auténticas se valieron de fuentes originales (documentos, tratados, cartas) y manuscritos que pueden ser entendidos como estados anteriores al cierre de la obra, que son utilizados para rescatar el contexto original de la práctica.

Se considera que la partitura representa el estado final de la obra según la intención del compositor. En nuestro estudio, hemos visto que el performer se vincula con la obra en una relación a través del tiempo, pasando por instancias que consideramos como diferentes estados de la obra. Durante la preparación de la obra, se identifican procesos en avance: la preparación de la obra a través del tiempo avanza sobre una maduración o profundización de la interpretación en la que pueden identificarse aspectos estables y variables. Este proceso se encamina hacia la producción o creación de un estado de interpretación de la obra que el performer reconoce como propia. Sobre esta base que podemos considerar como estable, o interpretación construída, los performers realizan diferentes versiones de la obra durante sus actuaciones en público. Luego de la presentación en público, el trabajo con la obra continúa sobre la base de los aspectos estables, a partir de los cuales se producen modificaciones o se abordan aspectos técnicos de la interpretación.

La relación entre el performer y la obra es entendida como una variación en el tiempo, donde el músico puede ser modificado por la obra, cambiar su visión respecto a ella y profundizar en su comprensión. En este proceso temporal, la obra sigue siendo vista por los performers como algo que no cambia.

A partir de la presencia de entidades estables y variables que intervienen en la práctica de los performers, hemos propuesto que el performer puede ser considerado como un narrador en la construcción de una entidad que permanece estable a lo largo de una serie de actuaciones en público, entidad que puede ser definida como su 
interpretación de la obra. Debido a que esta entidad difiere de la obra (puede ser revisada y modificada en estados futuros), entendemos que puede ser considerada como una narración (interpretación) que es construída en relación a una historia (obra). Como creación del performer, la narración surge de las oportunidades que presenta la obra para ser narrada: (i) la indeterminación del texto musical; (ii) la indeterminación de la situación y el contexto de la performance; (iii) el estado del performer que incide en la versión que finalmente se produce como un acto.

Esta construcción del performer difiere de la obra en el sentido que está informada por la experiencia de la situación de comunicación de la obra en la performance, lo que la distingue del estado final de la obra del compositor. Como narración, la interpretación difiere de la obra al mismo tiempo que es distinguible con respecto a otras interpretaciones de otros performers. Es por esto que consideramos que lo narrado en la performance es una construcción propia de un performer a partir de la intencionalidad de comunicar una obra musical.

A partir de estas consideraciones la obra, tal como la recibe el público, es "producto" de un "proceso" iniciado por el compositor y presentado por el performer en una actuación, donde su interpretación está mediada por la participación de otros agentes, ya sea en una serie estados que la obra adquiere en el marco de una práctica cultural, o sujeta a verificaciones interpersonales. En este sentido, la composición como el texto que representa las intenciones del compositor no es igual a la obra. Según Ingarden (1986), las partituras y las performances son determinadas en sus cualidades, mientras que las obras son indeterminadas al permitir muchas interpretaciones posibles. La obra -como algo abstracto y doblemente alejado del mundo real- es un objeto intencional que depende de su existencia en las mentes conscientes y en los objetos reales que existen en el espacio y el tiempo, capaces de ser transmitidos inmediatamente a la percepción. En la partitura, además, existe un espacio para varias interpretaciones, imprevistas por el compositor, por lo que la obra existe heterónomamente a través de los actos intencionales de los performers y los oyentes. Es por esto que, al decir que la obra es indeterminada entendemos que es el performer quien la determina en la performance a través de la creación de una interpretación propia -aunque sujeta a verificación interpersonal- que aquí entendemos como una narración que existe heterónomamente a través de los actos intencionales entre un narrador y un narratario. Por lo tanto, lo narrado -entendemoses algo que pertenece a todos. 
PARTE 4

Apéndices 


\section{APÉNDICE 1}

\section{Entrevista 1}

\section{Guión de la entrevista}

1. Hábleme de su primer profesor/a de piano.

2. De todos los profesores que tuvo, ¿Cuál fue el/la profesor/a que más lo/la influyó? ¿Por qué?

3. ¿Piensa que en usted han quedado cosas de él/ella? ¿Qué cosas son? ¿En qué lo nota?

4. Me interesa saber cómo usted prepara una obra a partir de una partitura. Me gustaría saber como es el primer encuentro con la partitura y cómo se van dando las cosas a partir de ahí.

5. ¿Piensa que el compositor se comunica de alguna manera con el intérprete? ¿En qué momento se produce esa comunicación? ¿En qué consiste?

6. ¿Tiene en cuenta intenciones del compositor en la obra para prepararla? ¿Cómo llega a esas intenciones, de qué manera, o de dónde surgen?

7. ¿Puede imaginarse al compositor trabajando con la obra o tocándola?

8. ¿Tiene en cuenta la/s interpretación/es de otro/s músico/s cuando prepara la suya? ¿Cómo las considera?

9. ¿Realiza la preparación de la obra en solitario o con otros? ¿Recibe ayuda, opiniones o sugerencia de otras personas? (los maestros, los profesores, otros músicos, otras personas) ¿importa o influye en su manera de preparar su interpretación?

10. ¿Para quién toca? ¿Toca para alguien? ¿Toca para usted o toca para otros?

11. ¿Cómo se hace para tocar para otros? ¿cómo se vivencia? ¿qué cosas pasan?

12. ¿Piensa que antes de la performance o mientras ocurre los demás están esperando que la toque de cierta manera o esperan que en algún momento ocurran ciertas cosas? ¿Y cómo hace para manejar esa expectativa de los otros?

13. ¿Es posible tocar para uno mismo? ¿Cree que hay una comunicación con uno mismo? ¿Cómo se vivencia? ¿Qué cosas pasan? ¿No hay nadie más en ese momento?

14. ¿Cómo sería tocar para el compositor? ¿piensa que de esa manera se comunica con él? ¿se imagina lo que él piensa o pensaría de su interpretación?

15. ¿Y dónde está entonces el compositor? ¿cómo se lo encuentra o dónde se lo encuentra? 


\section{Temáticas del análisis ${ }^{79}$}

\section{1. ¿Para quién toca el performer?}

La pregunta acerca de para quién toca el performer es amplia, y será más desarrollada más adelante en relación a otras preguntas que indagaron el 'tocar para otros', 'tocar para uno mismo' y 'tocar para el compositor'. En esta primera pregunta abierta, los músicos tuvieron mayor libertad en desarrollar su propia respuesta.

(1)

M - Es lindo tocar para alguien, que alguien te esté escuchando.

Yo cuando toco para mí es porque estoy creando, porque estoy probando cosas. Pero cuando las tengo decididas me gusta que alguien las escuche.

(2)

M - No sé, a veces toco para mi pero también toco para otros. Me gusta cuando estoy tocando y viene alguno de mis hijos, "que lindo", o que se yo.

(3)

M - Yo creo que en definitiva y en resumidas cuentas para mi. Es como un desafío, y cada cosa nueva es un desafío. Yo creo que lo hago para mi, es medio narcisista, es así.

I - ¿Y para otros también tocás?

M - Si se da la oportunidad de un concierto si. Y si no, no dejaría de hacerlo digamos.

(4)

M - No sé, eso es difícil. Para ser honestos, te puedo decir para quedar bien que es para los demás. La realidad es que también uno toca para uno. Para los demás y para uno. Uno nunca está en un frasco hermético. Pero es para uno.

(5)

M - Muchas veces me pregunté ¿por qué hago música? Si es mi decisión, si es mi deseo realmente... Porque al venir de una familia de músicos es como que un poco "es lo que hay que hacer". Y bueno yo estudié psicología, me acuerdo, dos años y después me di cuenta que el escenario, el instrumento, el tocar, como que a mi un poco... no sé como explicarlo, siento como una sensación en la panza, se me acomoda el cuerpo. Me di cuenta que es realmente lo que quiero hacer y donde me siento muy cómoda, donde digo "bueno, esto quiero". Siempre.

Pero después siempre pensé ¿y para qué quiero esto? Bueno, para mí, por mi bienestar digamos. Es algo que siento que lo tengo que hacer por mí, por el placer que me genera.

Pero también lo he pensado ¿toco para otras personas? O sea como que a veces, de esa retroalimentación que uno tiene del público me hace algo a mí, viste, me genera como un placer. Entonces también me he preguntado "capaz toco para otros" una especie de ego que se alimenta, de músico, pero es un ego propio también porque yo quiero eso de mi. A mi me da placer tocar. Entonces lo voy a seguir buscando.

I - ¿Pero también pensás si para los demás también estás generando algo?

M - Sí, sí, lo pensé, lo pienso. Pero ahí también está la pregunta de si toco por mi familia, si toco para mi familia, para mi viejo, para mi abuelo. Y de repente no era por ellos, sino como que siento algo como muy físico, como muy del cuerpo.

Todo lo que hago es música casi. Y es como que en un momento, cuando era más chica y tocaba el piano estaba horas y horas, no sé, ocho horas tocando el piano sin parar y mi mamá llevándome la comida al piano y era bueno "salí un poquito".

${ }^{79}$ En las transcripciones, las iniciales que se presentan antes de los diálogos identifican al entrevistador y al entrevistado entendidos respectivamente como investigador (I) y músico (M). 
(6)

M - Y, yo toco... arranco tocando para mí.

(7)

M - Para la música. No es la música por la música, porque todo se sitúa en un contexto histórico, tratando de que la gente y uno se acerca a cosas más verdaderas, con una persona vinculada a lo individual y a lo colectivo. Desde ese punto de vista me parece que una presentación nunca debiera ser en una sola dirección, que la gente vaya a escuchar como yo toco, o que la gente vaya a disfrutar de como toco. Me parece que lo bueno está en la obra, en lo que a esa gente le pasa estando al lado de otras personas; $y$ uno aunque esté en el escenario está como en un círculo con todos los demás. Lo otro sería persistir en un individualismo que sería como clasista de alguna manera, y nunca inclusivo, viste.

(8)

M - Para ninguno, y para mí tampoco. Tocás y te comunicás con la "cosa". Como cuando tocaba con Gerardo Gandini, que se armaba una "cosa" ahí. Bueno, vos te comunicás con ese mundo ahí. En vez de "cosa" llamale "mundo", donde están todos ahí. No tocás para éste, para éste, para la otra. Para mí esa es una imagen romántica, que "vos pintás para tal", o componés, o... a lo sumo la dedicatoria viene después.

Yo pienso que no se puede decir "toco para tales". Yo soy peor, "para una cosa", "me meto en una cosa", "y una cosa que es un mundo" ¿cómo lo traducís Matías? (ríe).

I - A veces te dicen "tenés que tocar para..."

M - Yo entiendo porque alguna vez lo he dicho. Pero yo le agregaría "tenés que tocar para...." te diría, "tenés que tocar para... también". No se si completa la pregunta. Yo al principio lo pensé en el sentido romántico. Que estaban en el público dos personas y querías tocar para ellas o que se yo, una enamorada que tenés por ahí.

I - Por ahí alguien te va a decir "yo toco para mi madre"

M - Y está bien, es válido. Yo pienso que no se puede decir "toco para tales". Yo soy peor, te dije "toco para una cosa" (ríe) Me meto en una cosa, una cosa que es un mundo. ¿Y cómo lo traduzco?

(9)

M - Creo que hay como muchas respuestas. Uno en primer lugar toca para uno, porque no te están obligando, en principio. Si tengo que decirte, lo que más he disfrutado es de tocar para mis amigos, para mi familia. Es un otro cercano, con el que tenés vínculo. Para alumnos. Siempre me gustó más eso que tocar para un colega.

El tema de llegar a saber uno para qué hace las cosas, que peso tiene en tu vida tocar, también. Cuánto querés darle, cuánto no, hasta donde. Y el tema de hacer las cosas justamente por ese interés genuino artístico que uno no tiene pero que bueno, que como es personal no va a ser el mismo de... ni el mismo de...

\section{Obra musical}

La obra musical a menudo es entendida como la creación del compositor, o es igualada a la partitura (su escritura en texto). A partir de las palabras de los músicos, hemos identificado descripciones de la obra que la 'humanizan' o la involucran en relaciones humanas, en diferentes aspectos:

El performer establece algún tipo de vínculo con la obra que puede ser descripto en acciones sobre la obra (aproximarse, adentrarse), en acciones percibidas por la obra (ser atrapado, la obra me habla), o en acciones con la obra (comunicarse, encontrarse, convivir, dialogar, compenetrarse, relacionarse amorosamente). 
(i) La obra me atrapa

M - Yo tengo que ver qué es lo que me atrapa de esa obra para tener ganas de hacerla, porque hay obras que no me dan ganas de hacerla, no tengo ni ganas de tocarla. No me importan.

I - ¿Y porqué te parece que te gustan esas obras?

M - Supongo que serán reminiscencias de otros momentos. De mi vida, de recuerdos, de cosas que quiero, que anhelo, que se yo. La verdad que es interesante la pregunta, no lo pensé nunca.

(ii) Comunicarse con la obra (es un encuentro, es un diálogo)

I - ¿Y qué hay que hacer para entender la obra?

M - Comunicarse con la obra. Sentirla, sentir que te gusta, que querés decir algo. Tener una intención de comunicar algo.

Comunicarse con la obra es como tener un encuentro con la obra, ¿no? A mi me pasaba con algunas obras que me gustaban mucho, era como que tenía como un diálogo que acá hay tal cosa y lo quiero decir de cierta manera, como si se me representaba el autor también.

(iii) Convivencia con la obra (es un diálogo)

M - El problema es cuando vos trabajás, analizás, convivís con la obra. Esa convivencia para mi implica una relación dialógica con la obra. En esa relación hay un proceso de maduración hasta que llegues a comprender, a entender que los procesos de frase que vos querés hacer tienen que ser de tal o cual manera.

(iv) Compromiso con la obra (significado afectivo)

M - Primero un compromiso desde lo afectivo con la obra y que a vos te signifique algo, que puedas expresar en esa obra. Que te signifique algo no quiere decir que vos tengas consciente que significa. Ese nivel de comprensión no lo he buscado nunca. Nunca he buscado traducir en palabras qué me significa lo que estoy tocando. Pero si hay una cuestión que se llama emoción estética, a mi me pasa algo profundo con lo que estoy buscando.

Desde el punto de vista interpretativo tiene que tener un significado lo que estás tocando. Un significado previo o que se va armando ese significado a medida que vas estudiando la obra.

\section{(v) Compenetrarse (meterse dentro)}

M - Lo mas importante es compenetrarse, saber del autor de la obra. Después uno se aproxima a la obra y se pone dentro de la obra. Después de leer uno tiene que meterse adentro de la obra. Eso lleva tiempo.

I - ¿Qué sería meterse dentro de la obra?

M - Hacer el fraseo, hacer la expresividad, hacer "¿qué quiso decir este con la música?”.

(vi) Relación amorosa: escuchar a la obra (desde adentro)

M - Es todo un caso de relación amorosa con la obra. En primer lugar, si vos la hacés es porque la necesitás. Y una vez que te ponés a hacerla ella te va diciendo cómo: por acá, por allá... Bueno, te va diciendo la manera, la forma... Como cada lectura me saldrá diferente, o a veces me cierro y digo "voy a cerrar el libro hasta mañana porque tengo ganas pero no me da, o no lo entiendo". Con la música pasa lo mismo, pero no 
viene desde afuera en buscarle qué. Sino, desde adentro te va diciendo cómo. Un maestro, Jacob Fischer, me decía "una obra es buena cuando te deja ganas de seguir escuchándola". Cuando vos hacés una obra sin trabajarla desde afuera, y te va diciendo todo, te deja para después; o también te dice "dejame descansar un rato", "estoy cansada". Por eso te digo, es casi una relación de amor. O es una relación de amor. Lo que pasa es que los términos a veces se confunden mucho.

\section{Texto musical}

Cuando fueron consultados acerca de la preparación de la obra a partir de la partitura, todos los músicos hicieron referencia a la lectura del texto musical de acuerdo a las categorías de la teoría musical (melodía, armonía, contrapunto, ritmo, etc.) y el análisis, como un proceso que se realiza de manera externa hacia un objeto. En cambio, encontramos algunas descripciones que se destacan por el uso de analogías literarias y el rol del lector como agente interactor.

Los primeros tres fragmentos que presentamos aquí, se refieren a analogías entre la lectura de una partitura y la lectura literaria. En el primer caso, la novela es entendida en términos de la expectativa del lector y la sorpresa. Luego, la analogía con la poesía se refiere a la diferencia entre la textualidad y la oralidad en música. El tercero se refiere a una analogía con una historia y el modo en que el lector completa el sentido, donde cada lector construye de manera imaginativa.

Los dos últimos ejemplos se refieren a interacciones con la partitura. En el cuarto fragmento, se produce un diálogo y una actualización de la obra, mientras que el quinto es una co-construcción de la obra entre el intérprete y el compositor a través del análisis de la partitura.

Analogía literaria 1 (la novela)

M - Yo antes la leía la partitura y quería... era como un libro de lectura, un libro que querés leerlo y entender, y agarrás la partitura y empezás a leerla, para ver que sale, la sorpresa. Eso fue lo primero que hice.

I - ¿Y eso del libro cómo sería? Explicamelo mejor

$\mathrm{M}-\mathrm{Y}$, vos leés una novela, tenés un libro. Cualquier novela linda, "ay, ¿cómo será?" $Y$ empezás a leer. Y ya te dejás llevar por el libro. Es lo mismo, leés la partitura y te dejás llevar por la música que sale, y te sorprendés, porque no te lo esperás lo que viene.

I - ¿Y se parece la música a una novela, por ejemplo?

M - Sí.

I- ¿En qué se parece?

$\mathrm{M}$ - Bueno, en una novela o en una parte de una novela, sí. $Y$, en ese lenguaje que te va sorprendiendo. Una música buena, si te sorprende es linda. Lo mismo que un libro, tenés un libro todo aburrido lo cerrás y no lo leés más.

Analogía literaria 2 (la poesía)

M - Para mí una partitura no es difícil de entender, es difícil de explicar. Por equis motivo, a lo mejor por los medios de la época en que yo estudié, donde conseguir una partitura... era copiarla, costaba el papel, costaba que te la prestaran para copiarla... porque siempre hubo mucho egoísmo en música. Faltaba lápiz para... Aunque parezca paupérrima, la comunicación hoy, era así, aunque no es totalmente válida, porque si uno se esforzaba tanto en conseguir tal obra... Digamos, las obras, o los estudios, era porque vos los habías escuchado, por eso los querías.

No, me pasaron cosas peores! tener que, como no había grabadores... (ríe) hasta que descubrí el primer grabador a alambre -mirá si soy viejo-, entonces uno registraba la música, a través de los signos. No es ninguna maravilla, es lo mismo que vos al leer un 
libro: leés una poesía cualquiera, en castellano o no -depende del acceso a los idiomas que tengas-, y vos sabés decodificar lo que es un texto a la oralidad, a como sonaría eso.

Analogía literaria 2 (la poesía)

M - Hay una parte en la que vos simplemente le ponés tu atención a las notas. Hay una parte de prestarle atención. En la medida en que uno trabaje en escuchar como es lo que está tocando, y cada nota, prestándole atención todas las notas, ahí lo estás diciendo. Porque vos le estás prestando atención y lo vas a decir de alguna manera. Te lo comparo con una poesía. Si agarrás una poesía y la lees (tacatatata) es una cosa. La estás diciendo, la estás leyendo correctamente, y aún si lees las puntuaciones correctamente. Aunque hagas el punto, no es lo mismo que hacer toda la gestualidad.

Analogía literaria 4 (la historia)

M - Es hermoso saber leer. Pero no de bajar las teclas. Saber leer implica el contrapunto, saber los acordes, saber de morfología. Yo tengo un $A$ y un $B$ y cuando vuelvo al $A$ yo tengo que ir recordando de alguna manera para mantener el discurso que estoy haciendo... recordar como largué. A lo mejor la intencionalidad es otra, emotivamente estás más como parado en otro lugar. Pero vos tenes que ir traduciendo para vos la emoción que vayas teniendo pero no te podés desbordar ni pasarte porque el que está escuchando tiene que entender también que está pasando.

A mí me parece que abordar la obra desde una partitura, si uno no va solamente a bajar la nota, es como leerte un libro... una novela. Al menos debiera ser así.

I - ¿Por qué?

M - Porque hay toda una historia ahí adentro. Pero la historia no te viene ni traducida en el lenguaje oral en el que hablamos, sino que está en otro lenguaje, así que todo lo imaginario que vaya pasando... Io imaginario puramente sonoro o emotivo, esa es una construcción que hacés vos, pero es un libro que estás leyendo, ¿entendés? Yo agarro una obra... este Murakami. Los libros que he leído las traducciones no me parecen tan fieles. Pero yo me imagino toda una situación. Y por ahí mi hija lee el mismo libro y se imaginó, pero el paisaje para ella era verde y para mí no lo era, ¿entendés? Entonces yo digo hay una construcción en la obra, con un lenguaje distinto, pero hay una construcción, hay una narrativa, puramente musical, pero es narrativa ¿qué otra palabra le puedo encontrar'

Interacción 1 (diálogo)

M - Lo primero que hago es decodificar. Así, jtac! A secas. Y después, a medida que la vas tocando, como que es un diálogo contínuo con la partitura. Como que vas descubriendo cosas, la música te devuelve otras cosas, y así, que se yo. No sé.

I - ¿Y cómo sería ese diálogo?)

M - Es como que todo el tiempo se va actualizando la música en vos. No es lo mismo tocar una cosa después de un mes que el primer día que la empezaste a tocar. Como que ya vas a niveles más macro, digamos, de lo que suena. No estás tan pendiente de por ahí "ay, esta parte no me sale" o "éste dedo". Como que ya fluye y bueno vos ya te vas como preguntando otras cosas.

Interacción 2 (co-construcción)

M - Yo no me coloco en un lugar así.... Yo construyo la obra con el que la hizo, eso es lo que para mí es atrapante.

I - ¿A qué te referís...? 
M - Qué análisis yo hago de la obra, qué me imagino que el compositor quiso decir y qué es lo que yo quiero decir con esa obra. Elijo esa y no otra, ¿no? A esta altura uno elige lo que tiene ganas de tocar, cómo y de qué manera, ¿no?

Entonces, lo primero que hacés es hacer una lectura muy difusa, ¿no? Y eso te da una idea de lo que vos vas a querer lograr musicalmente y a partir de ahí hacés la elección de cómo la vas a trabajar técnicamente. Si quiero lograr esto voy a trabajar técnicamente esto, lo voy a encarar desde este lado.

\section{Compositor}

Varias de las preguntas de la entrevista se referían al compositor. Las temáticas del análisis en una primera etapa distinguen: (i) la comunicación compositorperformer y viceversa; (ii) el reconocimiento de las intenciones del compositor en la partitura o la obra; (iii) tocar para el compositor; (iv) imaginar al compositor; y (v) ¿dónde está el compositor?.

(i) La comunicación con el compositor

Opiniones acerca de la comunicación

(1)

I - ¿Uno se comunica con el compositor?

M - Sí, yo creo que sí, uno siempre se comunica con el comp... Si el compositor se quiere comunicar con uno no sé, pero uno con el compositor sí.

(2)

I - ¿Pensás que el compositor se comunica de alguna manera con el intérprete?

M - Yo creo que el que más se comunica con el intérprete es el compositor del siglo veinte en adelante, sencillamente porque... antes el compositor componía sus obras para tocarlas él.. Había un doble juego... Cuando se produce esta división de tareas trae más que una dificultad. Hubo momentos de mucha enemistad entre compositor e intérprete. Ahí por ejemplo en un tiempo yo hice dirección contemporánea y era fantástico porque estrenábamos las obras, entonces uno era como ese mediador entre el compositor y el intérprete, y hay más puntos de encuentro que de desencuentro.

Creo que el compositor... Es importante la tradición escrita y es importante lo que pueda transmitir desde lo que está escrito. Pero bueno, yo creo que ahí se las tiene que ver... viste como es la construcción, vas a tener el compositor que te anote todo porque va a querer que se haga de esa manera... eso... es una pavada grande como una casa, es inexistente aparte. En tal caso lo deberá él porque es ahí no entender cual es el rol del intérprete, que interpreta, no lee lo que anotás, interpreta lo que anotás. Bueno, ahí hay una cosa que es fuerte. La interpretación no es una cosa menor, habla de una subjetividad, de una construcción subjetiva, viste.

(3)

I - ¿Pensás que el compositor se comunica de alguna manera con el intérprete?

M - Yo creo que... volviendo a esto que te decía, de leer una novela, o un cuento... Desde ese punto de vista sí hay una comunicación.

(4)

I - ¿Te parece que el compositor se comunica con el intérprete?

M - Ahí vamos a las cuestiones más ideales. Literalmente no, obviamente, pero sí.

Cuando uno dice que parte del papel es porque parte de ser muy respetuoso de lo que evidentemente alguien escribió, pensó, con un código que es limitado, felizmente 
limitado (ríe), sino no habría nada que hacer. Y que hace también que la música se renueve.

Pero uno no se olvida que hay alguien que se esforzó por escribir. Hay compositores enormemente detallistas y creo que hay que ser puntilloso, en darle la vuelta a todas las cosas que se pusieron en el papel. Porque bueno, hay alguien atrás que trabajó mucho para escribir eso. Creo que pasa por ahí.

Sí, en ese sentido te conectás, pero bueno la lectura es indefectiblemente propia. Yo trato de ser respetuosa porque la obra no es mía, pero no puedo ser él tampoco (ríe).

(5)

I - ¿Te parece que el compositor se comunica con el intérprete?

M - Y, tendría que ser sí. Si pudiera.

I - ¿Y en qué momento? ¿Cómo se produce esa comunicación?

M - Sí, estamos hablando de compositores que ya no viven. Qué difícil que es esa pregunta...

Y... ojalá me habría podido comunicar con Beethoven! Pobre, él dejó escrito lo que pudo, en la partitura, no dejó escrito todo. Pero después de escuchar, de tocar varias cosas de él, no una sola cosa, tenés que conocer mucha obra de él. Y oír, obras orquestales, de distinto tipo, creo que ahí le captás un poco, y ahí te comunica. En la diversidad de las cosas que hizo, no con una sola.

\section{Diálogos con el compositor}

(6)

I - ¿A vos te parece que el compositor se comunica de alguna manera con vos?

M - Sí, ahí no entramos en cuestiones metafísicas, ¿no? (risas) lgual decilo, podés decir mi nombre y que yo creo en el más allá, también si querés, yo no tengo problema. Lo cual sería un halago. La Rosalyn Tureck decía que hablaba con Bach, lo cual me parece maravilloso. La envidio a la Turek, digamos.

El asunto es que, en realidad, en ésta relación dialógica que te comentaba recién, yo encuentro un ser humano ahí atrás. Un ser humano que está diciendo cosas, que sufre o que está alegre, o tiene una nobleza extraordinaria en lo que está planteando, que genera expectativas, que habla sobre el tiempo y el espacio. En ese sentido me parece comprender realmente qué es lo que... en éste diálogo con el compositor.

Las indicaciones en la partitura

(7)

I - ¿Te parece que el compositor se comunica de alguna manera con el intérprete?

$\mathrm{M}$ - Sí.

I - ¿Cómo?

M - Y, desde las indicaciones que tiene la obra. De la partitura.

(8)

M - Depende de qué compositor, que se yo. Hay algunos que tratarán no de indicar, sino de imponerse mucho. Sobre todo lo que es la música contemporánea. Ahí no hay muchas cosas libradas a la interpretación, está como todo muy pautado.

En cambio, una obra de Poulenc, por ejemplo, que estoy tocando una con un flautista. El tipo te tira un "usá el pedal como si fuera un baño", como que te estés bañando las notas con pedal. Eso está buenísimo! Te abre una imagen sonora directamente.

I - ¿Lo pensás como una comunicación?

M - Sí, porque el tipo te está diciendo cómo quiere que suene ese pedal, no es cualquier pedal. Es como si estuvieras bañando las notas, está buenísimo.

I - ¿Y si no fuera por la partitura? 
M - No, salvo que el compositor esté vivo (ríe). Creo que no.

\section{Preguntas}

(9)

M - Por ejemplo, me pasaba con Chopin, como que me apabullaba porque sentía que eran preguntas y preguntas y preguntas sin respuesta.

I - ¿De dónde salían?

M - Salían de mí pero como que él escribía preguntas, frases que no tenían como respuestas, estas cosas más existenciales permanentemente. Me apabullaba eso. En realidad era como que me inhibía más de lo que me estimulaba.

(10)

M - Mirá, en una cuestión muy personal, yo a veces siento que dialogo con Beethoven, cuando estoy tocando sus sonatas... No es ninguna cosa misteriosa, simplemente... en el sentido de lo que me pasa con una obra musical que veo un ser humano atrás, que compuso eso. Que se yo, el 15 de Mayo de 1797 Beethoven estaba en el compás 15 de la sonata pastoral. El tipo está haciendo eso, entendés? Es algún ser humano que hace eso.

Me gusta como esa suerte de diálogo. A mi me interesa mucho Beethoven por su capacidad de correrse de las estructuras dogmáticas, digamos ¿no? Yo lo veo un tipo, un gran revolucionario. Un explorador extraordinario de ese mundo de sonoridades que siempre te conmueve.

Entonces, pensar el Beethoven de la novena, de ese himno final, pensar el Beethoven de los últimos cuartetos... Dialogar con ese hombre que uno (está a) muy pero años luz de distancia de vivir lo que él ha vivido. Pero comprender mínimamente que lo que está haciendo en los últimos cuartetos, ese canto a la humanidad del himno a la alegría "hermanos, hermano, uníos" ¿qué está diciéndole al mundo? Es emocionante, ¿entendés? Porque son tipos comprometidos con una cuestión política, social, de una gran convicción personal.

Entonces lo siento a veces como un amigo, que a veces (ríe), en algún punto, salvando las... kilómetros y kilómetros de años luz que hay, digamos, es decir, bueno, encuentro a alguien con el cual mínimamente uno entiende que le pasó en su soledad.

1 - ¿Eso es a través de una obra?

M - Sí, es a través de una obra. Ahora estaba trabajando... retomando, mejor dicho, la pastoral. Es un canto bellísimo, una pintura exquisita...

Son mundos realmente tremendos, de conflictos y de cambios de estado de ánimo internos, no? Sistemáticamente. Entonces digo "¿qué te pasa acá?" "¿qué te pasa acá?" "¿qué andás pensando acá, Luis?" (ríe).

(11)

I - ¿El compositor se comunica con el intérprete?

M - Sí, por supuesto. Yo a veces digo "¿para qué escribiste tal cosa?" (ríe) ¿y esto? ¿para qué pusiste esa nota ahí?

\section{Tocando}

(12)

I - ¿Te parece que el compositor se comunica de alguna manera con vos?

M - Yo tengo comunicación con... hasta determinada época de la historia. Porque los de ahora no, conmigo no, no somos amigos. (ríe) Yo por ejemplo llegaría hasta un Debussy, Grieg ahora me estoy comunicando. Uno se da cuenta cuando toca.

I - ¿Y cómo sería la comunicación? 
M - Uno se siente cuando toca, un placer increíble. Una cosa que se va de uno de donde está. Se va, o sea, entra en un mundo nuevo. Yo sentí una vez que me iba así (hace el gesto con las manos hacia arriba) y volvía, delante de mi profesora. Estaba tocando 'El jardín bajo la lluvia' de Debussy. Y en un momento dado la miro y me sentí ir y después volver. Así que con Debussy también somos amigos. (ríe).

\section{Desde lo afectivo}

(13)

I - ¿Te parece que el compositor se comunica de alguna manera con el intérprete o con vos?

M - (silencio, piensa) Termina habiendo supongo algún tipo de comunicación.

Hay a veces una cuestión como de conexión, por lo menos sí, uno dice... yo agarro algo de Bach, a me gusta, y yo siento como que "uh, qué groso esto!", me llega. Siento como que... como que uno se vincula afectivamente ¿no?, de alguna manera... como que llega, que le llega la música que el tipo compuso, te está llegando y uno como que se vincula.

(ii) Intenciones del compositor

Intenciones en la partitura

(1)

I - ¿Tenés en cuenta intenciones del compositor cuando estás preparando tu interpretación?

M - Eso es fundamental, porque sino es como que estás...

I - ¿Cómo hacés para encontrar eso?

M - Y, en la música contemporánea hay mucho escrito, tenés que conocer de la estética, tenés que conocer por dónde va. Qué estética plantea... El análisis de la obra es fundamental, es tu rol porque sino... si tenés al compositor a mano mejor aún. A veces el intérprete encuentra algunas cosas que el compositor las dejó y que es fantástico, o sea... bienvenido sea, una lectura nueva o como lo sostiene, que se yo, no sé.

(2)

I - ¿Es posible llegar a las intenciones del compositor?

M - Si, pasa mucho con las partituras que es muy difícil reconocer la intención del compositor. Justamente está el tema de los estilos, que es como una intención de época determinada, que suene de determinada manera. Entonces en principio es el problema del papel, que uno no sabe cuáles eran claramente las intenciones.

Yo de lo que soy partidario, un poco... Digamos parto de la base como del respeto a la obra. Entonces un poco me propongo, creo, dentro del marco de libertad y todo, pero tratar de no modificar la obra intencionalmente. Por ahí no sabés cuál era la intención del compositor, podés suponer determinada cosa, puede haber una indicación en la partitura... y bueno, y si choca con mi manera de ver, una reacción típica es "y sí, puede ser un error". Si no lo tengo al compositor para preguntarle (ríe) y hay una indicación que realmente no me cierra, puedo ser capaz de decir "uh, este piano acá...". Sabés que puede pasar eso con la obra y bueno...

Lo he escuchado a Brouwer una vez que vino, estaba preparando la obra con un muchacho y le dijo "claro, sí, lo que pasa que eso que puse ahí no funciona, ¿quién habrá escrito esta tontería?" hizo un chiste ahí. "Habría que hacer tal cosa" Le modificó un par de cosas, pero hizo referencia que eso ahí... reconoció que de alguna manera fallaba. No paso que corrigió todas las obras, es algo que pasó. Y yo creo que nunca es nada más importante que la música, esto de la interpretación. Me parece que es 
como una cuestión como de respeto mutuo. Que el compositor tiene que darle la libertad al intérprete, tratar de orientarlo con las indicaciones si uno cree más claramente que esto tiene que ser más melancólico, o como sea, y que el intérprete tratar de respetar, si le pusieron la palabra melancólico, esforzarte para que sea melancólico sería como bien. Sería un tema de respeto, y tratar de ver...

(3)

I - ¿En ese diálogo tenés en cuenta intenciones del compositor?

M - Bueno, podemos observar que hay cuestiones que él quiso decir, entre comillas en ese "quiso decir", que es una cuestión ajena a uno, tal o cual movimiento o tal o cual planteo estructural...

Las Intenciones del compositor en la interpretación

(4)

I - ¿Tenés en cuenta intenciones del compositor cuando preparás una obra?

M - Sí.... igual, creo que está mejor que no suceda eso. Como haberlas, las hay y a veces decís "ya fue", Beethoven está muerto, listo (ríe). ique se revuelva en su tumba!

Capaz que uno está errado y en realidad eligió una tonalidad menor y una melodía super triste pero él no se emocionaba con eso. Desconozco. Es toda una suposición que nosotros hacemos, pero no podría afirmarlo.

I - Pero, si llegás a las intenciones del compositor ¿cómo llegás?

M - Y, está medio despersonalizado me parece. Por ejemplo pasa mucho, mucho mucho con los metrónomos que te ponen a veces "negra 100", y vos te das cuenta que no funciona tocarlo a veces porque no te dan los dedos, queda todo atropellado, lo que sea. Y decís "bueno, lo podemos llegar a hacer, pero la verdad, yo como que me desentiendo de esto" Yo lo hago, pero como que no le doy como mi sentimiento. Lo hago así "tiki tiki tiki tiki".

Y hay velocidades que está medias raras. Eso seguro. Pasa mucho con la música orquestal además. Pero cuando ya hay una cosa que está muy pautada, bueno okey, no queda otra. Tampoco es que te voy a decir: "aguante la rebeldía y hacer lo que uno quiera", ¿no?. Es como que si estás reproduciendo alguna estética y bueno, hay cosas que tenés que respetar a rajatabla. Pero trato de que sean las mínimas.

(5)

I - ¿Y tenés en cuenta intenciones del compositor?

M - Sí, todo el tiempo.

$\mathrm{I}-$ ¿Y cómo las encontrás?

M - No sé, en los detalles uno intenta acercarse a la intencionalidad del otro, del que estuvo del otro lado, por eso te digo hay alguien que se esforzó mucho en poner lo que está escrito, como pudo. Cuando digo 'como pudo' es porque el código es hasta ahí. Digamos.

(6)

I - ¿Podés ver en la partitura las intenciones del que lo hizo (el compositor)?

M - Si ves un crescendo y lo hizo el autor, más vale hacé un crescendo para respetar al autor. No hagas como algunos colegas que dicen "mirá, ¿no te gusta así?". Dejalo, dejalo como lo hizo el compositor, porque si él lo hubiera querido lo hubiera hecho así, lo hubiera escrito así, si no era imbécil, era compositor.

(7)

I - Ya me habías dicho que tenías en cuenta las intenciones del compositor. ¿Cómo llegás a esas intenciones? Dónde surgen... ¿Qué hacés para encontrarte con esas intenciones? 
M - Sí, hay intenciones, si. Pero si las tomo en cuenta, a veces sí, y a veces no. Eso tiene que ver con el músico, cuando agarrás una obra no tenés derecho a hacer una obra nueva jsi está ahí!

(8)

I - ¿Tenés en cuenta intenciones del compositor?

$\mathrm{M}$ - A veces sí, a veces no. Por ejemplo si tenés una parte que venís tocando una especie de mezzoforte, piano súbito. Ah bueno "el compositor quiere que en esta parte se baje de repente, acá subirse". Cosas de dinámica. Bueno, a ver porqué es eso. Pero que se yo, por ahí esa obra si yo la tengo que tocar por ahí la exagero totalmente. Por ahí no dice piano súbito, dice piano, bueno le hago piano súbito, esas cosas.

Por ahí el compositor me dice "acá hay varias partes que son diferentes", yo decido exagerarlas, o yo decido no exagerarlas, no se. Como que el compositor te dice algo a través del papel pero después..

\section{(iii) Tocar para el compositor}

Opiniones en contra

(1)

I - ¿Cómo sería tocar para el compositor? ¿Te parece qué puede existir eso?

$\mathrm{M}$ - No, nunca me lo imaginé. No lo veo así.

(2)

I - ¿Cómo sería tocar para el compositor?

M - Super interesante! (ríe) Yo creo que nunca le va a venir bien nada. A veces pasa con los compositores que vienen con unos planteos...

I - ¿Pero un compositor que no conozcas?

M - Yo creo que no, porque entrás en un terreno de a ver quién tiene razón o te va a dar una devolución de lo que es SU idea de la obra y vos estás en otra situación.

Se podría, hay gente que es muy de tocar Bach con instrumentos antiguos, estaría en contra de tocar con dos pianos porque en esa época no había piano.

I - ¿Y pensás que de esa manera se podría comunicar con el compositor?

M - No. Aparte, el tipo... jandá a saber! Capaz que compuso la obra y le daba lo mismo, no había nada para hacer y la compuso y le da lo mismo, que se yo!

Opiniones a favor

(3)

I - ¿Se puede interpretar para el compositor?

M - Yo creo que más que la comunicación es una especie de entrega de una forma de ver las cosas al otro.

Tocar para mí es como una especie de auto-conocimiento. Pero de tocar para el compositor es "bueno, yo te ofrezco una forma de ver tu propia música"

(4)

I - ¿Se puede interpretar para el compositor?

M - Sí, porque estás tocando su obra. Estás presentando como una versión de la obra. Entonces sí estás de alguna manera, y también buscando el aval de esa interpretación.

(5)

I - ¿Se podría tocar para el compositor?

M - Si, en el trabajo que tenés que hacer desde el primer minuto hasta, por supuesto, el 
vivo. En el respeto de re-crearlo, de buscar re.crearlo lo que uno fue construyendo a partir de lo que está y lo que no está en la obra.

I - ¿Es una manera de comunicarse con el compositor?

M - Sí, eso que te dije antes sí.

(iv) Imaginar al compositor

Tocando la obra

(1)

I - ¿Te imaginás al compositor tocando esa obra o componiéndola?

M - Sí, me pasaba mucho cuando estudiaba, que se yo, por ejemplo Chopin, esas cosas, me imaginaba que el tipo se sentaba en el piano e improvisaba. E improvisaba eso que estaba escrito, y venía así y lo escribía.

I - ¿Y eso lo tenés en cuenta como una imagen para después tocar?

M - Sí, sí, sí. Entonces yo a veces digo, "me gustaría improvisar en tal estilo", entonces me pongo a improvisar como si fuese tal compositor. Entonces, reconociendo ciertas formas estilísticas, me pongo a improvisar.

(2)

I - ¿Y te imaginás al compositor trabajando sobre la obra o tocándola?

M - Ay sí, eso es un... si, un trabajo de imaginación no sé, por lo menos mía, permanente, sí.

Sí porque quiero imaginarme que es una persona. $Y$ sobre todo cuando son compositores de ese tamaño. $Y$ son tan increíbles, y tan inagotables porque podés tocarlas, ya te digo, y volver a agarrarlas, y retomarlas con otra edad y otra madurez $y$ no se agotan, son increíbles.

Entonces sí, me gusta hacerme una idea de que es un ser humano el que compuso eso, es una cosa fabulosa.

Porque son tan increíbles, yo no las endioso, pero cuesta mucho pensar que es una persona con los mismos problemas que uno, en el sentido de que es un ser humano. $Y$ es una cosa maravilloso pensar que es una persona trabajando, siempre hago ese esfuerzo. Y si busco cosas del autor, anecdóticas es un poco para eso, para imaginarmelo trabajando, en su casa, en su escritorio, sí.

(3)

I - ¿Te podés imaginar al compositor trabajando con la obra o tocándola?

M - No. Con Tárrega sí, pero desde el punto de vista técnico. ¿sabés por qué? Yo aprendí la escuela Tárrega, a pesar de ser alumno de un ex alumno de su escuela, por las fotos, que ya existían. Entonces, no era como a mí me habían enseñado. (me muestra posiciones de la guitarra). Entonces a mi me ha servido para, de una fotografía, hacerme la película. E incorporarlo en mi forma, claro, tuve que cambiar. Era momento de hacerlo, si yo veía que lo tocaba él. Ahora, como sentía él o que... no sé, ni idea. Yo lo veía compenetrado con lo que estaba haciendo.

(4)

I - ¿Te podés imaginar al compositor trabajando con la obra o tocándola?

$\mathrm{M}$ - No. Cero.

(5)

M - No, me ha pasado en cualquier otro momento, pero tocando no.

Cuando leés algún libro de historia de la música. O cuando das una clase y hablás del autor. 
(6)

M - No. Es más, a veces que vos viste películas del tipo y por ahí te puede traer la imagen de la película, pero es una ilusión eso.

(7)

I - ¿Te imaginás en algún momento al compositor trabajando con la obra o tocándola?

M - Tengo la imagen de Kabalevski porque he visto fotos enseñándole a los pibes como ahí puesto a escribir. O Beethoven, ¿viste cuando te aparecen las fotos de Beethoven? Que el tipo se enloquecía escribiendo.

Pero No, no, no. Cuando estoy estudiando o tocando no

\section{Componiendo la obra}

(8)

I - ¿Te imaginás alguna vez al compositor trabajando o tocando la obra?

M - No, tocando la obra no me lo imagino al compositor. Haciéndola sí, creo que si.

I - ¿Y cómo te lo imaginás? ¿qué es lo que te imaginás que hace?

M - Bueno, yo hice Composición en la facultad, entonces por ahí estamos bajo la tutela del espítiru de Mariano Etkin. Esa cosa de mirar la parte, concentrarse y escuchar. Entonces yo me imagino ese tipo de composición. La verdad que es eso. Esa nota, buscada, pensada, elaborada, tachada, vuelta a pensar, ¿si?

I - ¿Vos tenés que hacer cosas similares cuando tenés que interpretar?

M - Yo creo que sí, sí. Hay una parte que es muy mecánica que por ahí es importante también entender que el compositor la tiene, no ésta estética pero está mecanicidad de hacer algo que tenga que ver con una mecánica, de componer algo que tenga que ver con conocer los yeites compositivos, o las técnicas compositivas, ¿no? Y eso lo comparo por ejemplo con lo técnico. Pero después sí, hurgar en la obra y analizarla y pensarla y volverla a tocar, y probar en el piano y cómo responde el piano y buscar otra opción por más que esa opción no sea la que elijas, ¿no?

(v) ¿Dónde está el compositor?

¿En la obra?

(1)

I - ¿Creés que está el compositor cuando estás tocando?

M - Sí, sí, de alguna manera está. Siempre está presente aunque yo no lo visualice o no lo esté nombrando en mi cabeza. La obra fue escrita por alguien, tiene sus giros, yo tengo mis libertades.

(2)

I - ¿Está el compositor cuando estás tocando?

M - Sí en la obra.

I - ¿Se percibe de alguna manera?

M - Sí, en la obra

(3)

I - ¿Y dónde estaría el compositor entonces?

M - Cuando yo toco, en ningún lado.

I - ¿En la obra tampoco?

$\mathrm{M}$ - No. 
(4)

I - Pero si tenés en cuenta sus intenciones, de alguna manera estaría ahí el compositor.

M - Y sí, está su fantasma.

I - ¿Entonces dónde está el compositor cuando estás tocando?

M - En ciertos puntos de la obra, cuando hace "click" con vos.

Puede estar en algún momento en la melodía, o en el ritmo, o en la armonía. En la armonía más. Yo creo que en la armonía nos encontramos todos.

I - ¿Se puede hacer algo para buscarlo?

M - Yo creo que sí, en la armonía, más que el ritmo. Bueno, en la melodía un poco más también. Pero más la armonía porque la armonía te está condicionando la melodía también. Es la base.

I - ¿Y que hay de él en la armonía?

M - Es un mundo. Subterráneo. Sus emociones, sus tensiones, sus distensiones.

(5)

I - ¿Y cuando estás tocando pensás que el compositor está?

M - Ahí no tanto. No se humanizo la partitura, no sé.

I - ¿Entonces dónde estaría el compositor, en una obra?

M - Estaría a través de esta cuestion de lenguaje, de lo que escribió, pero no sé si me encuentro exactamente con el yo te digo, más allá de esa experiencia.

Puede estar en el estilo. Si lo pienso desde el estilo sí está presente. Creo que sí.

\section{Otras interpretaciones}

Durante la preparación de la obra, los músicos en la actualidad no cuentan únicamente con la partitura como referencia para la performance. Al hablar acerca de cómo proceden desde el comienzo de la preparación, algunos músicos mencionaron la relevancia de escuchar o ver interpretaciones de otros músicos como parte del análisis y la comprensión de la obra. En otros casos, la pregunta tuvo que ser enunciada directamente.

Aspectos a destacar son el reconocimiento de la imposibilidad de replicar la interpretación de otro instrumentista y la decisión de construir una versión propia, personal.

\section{Escuchar/observar otras interpretaciones}

(1)

M - Sí, por supuesto, he tenido que hacerlo. Escuchar distintos, les he hecho a mis alumnos escuchar distintas interpretaciones de obras. Lo mejor es la mayor cantidad posible. Que ahora como tienen Youtube lo pueden hacer fácil.

(2)

M - Y sí. Sí. Nosotros, sobre todo cuando estudiábamos, que se yo, escuchábamos montones de versiones. $Y$ bueno, ahora también escucho aunque no esté estudiando una obra escucho muchas versiones y también me interesa ver lo gestual, el contexto, que se yo.

(3)

M - Sí, a veces observo a los pianistas, sus manos... me gusta ver lo que hacen. O por ahí me pongo a ver videos.

(4)

M - Después también voy a grabaciones, entonces comparo lo... escucho por ejemplo los pianistas así bien de renombre: Barenboim, todos esos. 
No escuchar otras interpretaciones

(5)

M - No. Detesto. De hecho no me gusta escuchar versiones previas. Como que yo reivindico mi descubrimiento de la obra. Después, quizás escucho alguna versión para ver si no le estoy pifiando a algo y no me di cuenta. Pero no, me parece que es una subjetividad que te puede influir y no está bueno.

I - ¿Y cómo te influiría?

M - Y, por ahí decís "porque lo hizo éste yo debería hacerlo así. Y no. Es algo que es arte, o sea. No hay una única verdad.

I - ¿Pero te ha pasado?

M - ¡Síl Me ha pasado de tocar con gente que te dice "no, tal lo frasea asi" A mí que me importa! (ríe) Dejame, yo soy yo, andá a tocar con ese si te gusta más. Y son como cosas que no tienen fundamento, "porque lo hizo tal persona tiene que ser así" iNo! Esa persona estaba en otro día que le salió diferente.

I - Pero te tiene que haber pasado que hayas tocado algo que ya hubieras escuchado antes

M - Sí, las menos igual. Siempre me gusta como despojarme de todo eso.

Acerca de la imposibilidad de replicar otras interpretaciones

(6)

M - Por supuesto, en muchos casos influenciados por el conocimiento que uno tiene de otras escuchas de grandes instrumentistas. Pero después está lo tuyo. Porque por más que escuches a Arrau todo el tiempo, no sos Arrau.

(7)

M - Y luego, la otra cosas que es muy importante, sobre todo cuando la obra es de trascendencia, y cuando el trabajo ya es muy avanzado, ya pasó mucho tiempo, es ir a las versiones. A las versiones conocidas porque necesariamente, cuando los intérpretes son de relevancia, ellos logran lecturas que uno a lo mejor es incapaz. Nunca son para copiarlas, no puedo tener esa aspiración porque no me saldrían. Pero son a veces para que me cierren cosas que no me cierran, para que me ofrezcan una lectura que no pude ver. Pero tratar de darle forma otra vez yo, porque copiar... no te sale.

La influencia de los intérpretes en la preparación de la performance

(8)

M - Como que si escucho un pianista que la interpretación sea como también un poco personal, reconocer a tal intérprete como tal, digamos.

Por eso siempre, si escuchas a Martha Argerich sí, Bruno Gelber tiene sus cosa viste, su estilo, y que lo hace su estilo, eso sería para mi lo más interesante.

I - ¿Tenés en cuenta interpretaciones que hacen otros?

M - No, no tengo mucho en cuenta a veces eso. He tenido en cuenta pero después no. Como que en un principio sí y después, como si fuese un punto de partida para una nueva creación.

(9)

M - Sí. Las escucho, me parece importante... escuchar como... después construís tu versión. Lo que por ahi es interesante es ver, algo que siempre me atrapa es relacionar el tempo con el sostén del discurso, viste que siempre lo que más suelta es el tema de... bueno, el tempo es diferente, ¿no? Y si ese tempo elegido distinto al otro se 
sostiene desde la elección musical o el tempo es caprichoso, o porque lo dice la partitura, ¿no?

Y una relación de cómo se sostiene el discurso a través del tiempo es importante, yo me pongo a pensar en eso. Hay versiones que me gustan más, hay otras que no. Igual, soy muy atípica en eso, realmente lo escucho pero no me... Me parece que es importantísimo, pero no para decir "bueno, lo voy a hacer asi" sino por entender por qué está dado de esa manera y si esa elección se sostiene en la acción. Te pongo un ejemplo claro: tal tempo resuelve los adornos de una manera distinta, por qué suenan... analizar eso, o por qué suenan también, viste.

(10)

$\mathrm{M}$ - Yo he tenido así como algunos referentes, del mundo global de guitarristas, como que aprendes de decir: "esto funciona" o "yo coincido con esto". Hay mucho que uno aprende de decir "coincido con esta manera de encarar la música". Entonces, yo escucho Julian Bream y coincido. Aunque después estudiás la obra y decís "esto yo lo haría distinto", pero escuchás y coincidis, porque musicalmente vos te das cuenta que te llega, que lo hace bien, que impacta.. Hay una cosa que cierra, perfectamente.

Yo creo que hay mucho que uno aprende de lo que suena, como Hopkinson Smith en lo que es el repertorio de Laúd que a mi me llega esa parte de la libertad que le ves a él. Está implícita la libertad.

\section{Otras personas}

Aunque preparen la obra en solitario, los músicos reciben comentarios, opiniones y sugerencias de los demás. A veces, esto se recibe a través de convivientes, amigos, colegas, profesores; la devolución puede ser espontánea o requerida. Una opinión es considerada también en el modo en que se enuncia, de acuerdo a quién lo enuncia, y requiere que el músico esté dispuesto para recibir el comentario de un 'externo' en su propia interpretación. La decisión final sobre estos aspectos involucra la consideración de una opinión de un 'oyente' experto o no-experto y la propia intencionalidad el performer para con la obra.

$(1)$

I - ¿Preparás tu interpretación sola o hay otra gente que te dice cosas?

M - Sí, hay otra gente que me dice cosas. Pero no profesores, amigos, compañeros. Yo estaba viviendo hace poco con otro pianista, y por ahí yo estaba tocando, venía y me decía algo.

(2)

I - ¿Recibís opiniones de otras personas?

M - Y sí. Acá en casa... jcon todos músicos que pasa uno y te dice algo! Sí, sí, claro que sí. Igual, siempre busco lo que quiero decir yo. En última instancia siempre voy a hacer ese recorrido.

I - ¿La última palabra es tuya? ¿A eso te referís?

M - Y sí, claro. Pero bueno, sí me influye. Pueden ser buenas ideas, pueden ser cosas, o pueden ser cosas que uno no se da cuenta que estás haciendo y...

I - ¿Te ha pasado que te sirvió algo?

M - Y bueno, con ellos sí. Por ahí viene alguien y estás estudiando, y te dice algo ... sí. Sí, en compañeros, sí. También pasa, sí, sí.

(3)

I - ¿Tenés en cuenta opiniones que recibís?

M - Depende de quién lo diga. Yo pienso que si, si es una persona muy importante que le creo, creíble para mí, sí. Sí que me influye. 
I - O sea que por delante está tu consideración de aquella persona y luego el mensaje...

M - Si no lo considero, obviamente que no me importa nada.

\section{(4)}

I - ¿Lo que dicen los demás te influye?

M - Depende de quién sea y cómo te lo diga, me parece. Siempre que tenga un buen fundamento para decir lo que diga sí. Más vale. Y los que no, no (ríe). Lo hacés más de gusto encima.

(5)

I - ¿Recibís ayuda de otros en tu preparación de la obra?

M - No, cuando ya la tengo más o menos pregunto. Pregunto o me gusta que la escuchen.

I - ¿Colegas o amigos?

M - Sí, sí. "Che mirá, escuchala, como va esto, o como...".

I - ¿Y qué te aporta?

M - Mucho. Te aportan siempre algo. Yo más que lo que dicen, escucho... es algo raro lo que pasa Matías, pero vos te das cuenta cuando el público está concentrado en lo que vos estás escuchando o no. Si no está concentrado es que no estás siendo convincente en lo que presentás.

I - ¿Recibís comentarios de otras personas?

M - Sí, cuando me pasa de recibir opiniones las tomo. Mientras las correcciones estén bien indicadas, está perfecto.

(6)

I - ¿Te ha pasado que te han dicho cosas mientras estabas preparando la obra?

M - Con la profesora sí, después con los colegas no. Porque vos perdés la personalidad.

Por ahí, si me han dicho. Y yo tomé ese concepto. Inclusive he aprendido de algún alumno. Y yo lo agregué a lo que estaba tocando. Depende esto, porque sino uno no tiene personalidad.

(7)

I-¿ Lo que dicen los demás te influye?

M - Y, habiendo hecho una carrera, no tenés más opción que mostrársela al profesor. Es para ver como uno va, que se yo.

I - ¿Pero hay lugar para el otro?

M - Sí, en mi caso sí. Yo soy potable para cualquier tipo de sugerencia. Eso sí, siempre lo voy a tomar como una sugerencia, siempre lo voy a tomar como una opinión. Porque sino entonces ¿mi opinión no vale?

Porque, al fin y al cabo, vos salís a un escenario (suponé) o un canal de televisión, y no sabés cuántos va a haber, no le vas a preguntar a cada uno qué opina. Vos salís y te vas a brindar, $y$ con todos pero... y si a alguno no le gusta, no le gusta... y tiene todo su derecho. Aún fijate que uso la palabra "gusto" que es la que más odio. Le puede gustar o no. Me da lo mismo. Ahora desde el punto de vista sensible, si está reaccionando al mensaje, bueno, está bien, o por ahí no... y tiene su derecho.

(8)

I - ¿Hay otras personas que te dicen cosas?

M - A mi me gusta más llegar en solitario, en cuanto a la preparación y eso. Si lo trabajé con alguien, me gusta tomar distancia. Pero si me das a elegir como prefiero ir a un concierto en la preparación, prefiero ir solo.

I - ¿Y te ha pasado que recibiste alguna opinión?

M - Sí, si, te escuchan y te hacen algún comentario.... Y, uno siempre los escucha. Si es algo que del todo no entendés, yo siempre hago el esfuerzo de tratar de escuchar lo que te están diciendo. 
A veces, por ahi te hacen un comentario y vos por ahí no coincidís de una... pero que vale la pena decir "bueno, ¿qué escuchó?, ¿qué está escuchando?, ¿por qué hace este comentario?" Te saca de tu punto de vista y te hace entender el del otro. Porque la otra persona por ahí te está reclamando "le falta algo", o "no tiene interés musical", es porque evidentemente no lo tenía. Podrá chocar pero bueno "a ver ¿qué podemos hacer para que lo tenga?" Y bueno, me di cuenta que sí, que había cosas para hacer. Creo que es bueno que haya una distancia, entre el momento que te dan una indicación, porque puede ser una persona fuerte, un profesor, y como te lo diga, y con qué grado de libertad.

\section{Uno mismo}

Como un primer oyente, el músico puede tocar mientras está solo en un tipo de comunicación consigo mismo. Varios músicos describen a esta situación como el impulso que genera posteriormente presentarlo ante un público. Este tipo de comunicación interna, por momentos afectiva, puede estar generando un tipo de comunicación que es la que se pone en juego luego, durante la performance.

(1)

I - ¿Cómo es tocar para uno?

M - Si yo toco para mi, yo soy el público. Siempre me estoy ubicando adentro tocando, y hay otro yo que está como afuera, siempre hay un público.

(2)

I - ¿Y cómo sería tocar para uno mismo?

M - El primer motor de lo que estás haciendo es porque te gusta. Entonces hay un goce en decir "estoy haciendo esto".

Hay una cuestión como de descubrir por ahí algo. Escuchaba algo la otra vez, el tema de la curiosidad y del artista, y el tema de los desafíos. Como te decía al principio, lo primero es escuchar algo "quiero tocar eso" o "quiero tocar esa obra". Es como el primer motor de poder ser vos el que está produciendo ese momento musical, algo así como ese placer... En el medio está que lo estás haciendo, lo vas a estar haciendo a tu manera inevitablemente. Y después de eso creo que llega la parte de decir, "bueno, esto lo quiero compartir". O a veces puede pasar "a ver, ¿qué podría compartir? Ah, esto que me gusta", es como que está medio conectado.

Hay algo del disfrute en primer lugar de decir "esto me gusta poder hacerlo yo", porque aparte, está inevitablemente esto de querer compartirlo, esto de querer mostrar el punto de vista.

(3)

$\mathrm{I}-$ ¿Y se puede tocar para uno mismo?

M - Si, en realidad digamos yo no lo hago consciente eso, no es que me pongo "voy a tocar para mí". Yo me pongo a estudiar una obra y por supuesto, un momento... la estudio toda completa, de principio a fin para ver bueno las cuestiones que van pasando. No experimento necesariamente que toco para mí. Siempre pienso, aunque esté solo en casa estudiando que estoy con otros, que esto es para alguien.

La experiencia que uno percibe al público en términos de estar presentes o estar... estar convocados a un discurso o estar escuchando un pianista, digamos, ¿no?. Cuando estudio solo realmente me pongo en la situación de "a ver cómo esto llegaría al público" porque a mi me produce...

El otro día estaba estudiando uno de los Scherzos de Chopin. Y había una cosa muy loca en el número uno, ¿no? Muy así, arrebatadora. $Y$ hay un problema técnico que tengo que trabajar todavía, no le encuentro bien la vuelta. Pero en un momento 
aparece, digamos. Y cuando me empiezo a enganchar en esa energía que genera ese comienzo arrebatador pasan cosas muy fuertes internas, como que uno se mete en esa agitación. Y ahí digo bueno "esto lo ofrezco", se lo ofrezco a la gente...

(...)

I - ¿Te ponés un poco en situación?)

M - Sí. Hay momentos que digo "bueno, estoy en un concierto", "a ver qué pasa"

I - Te proponés tocar en una situación, aunque no sea la actual. La creás, digamos.

M - Sí, sí, sí. Uno se crea eso para ver qué... porque también eso tiene que ver con... la manera de pasar una obra en donde sabés que no vas a parar, de principio a fin.

(4)

I - ¿Cómo es tocar para uno?

M - Y... escucharlo, tocar. "Qué lindo esto que está sonando" No sé, yo no pienso que lo estoy tocando... Yo la verdad Matías, que soy yo la que estoy tocando. Yo estoy escuchando lo que toco, que se yo. Me parece maravilloso. O no. Digo "ay que feo" pero sí, y eso es lo que comparto. Lo que me gusta de lo que estoy tocando, suponete.

I - ¿Uno se puede comunicar con uno mismo?

M - Sí, yo creo que sí. Porque el sonido te vuelve, vos lo producís, te vuelve. Es una maraña, sí. Te vas escuch... si no te escuchás, qué estás produciendo? Es... yo creo que hasta digamos ni siquiera hay una división, va y viene todo el tiempo. Circular, completamente.

(5)

I - ¿Se puede interpretar para uno mismo?

M - Sí.

I - ¿Y cómo es eso?

M - Y, cuando pruebo. Es muy romántica esa idea "sí, yo toco para mí mismo", "no quiero tocar en público", te dice mucha gente. "¿Para qué voy a estudiar música yo si a mi me gusta tocar para mí?", no, no me interesa. Cuando toco para mi porque estoy armando algo es una cosa desarmada, no tiene...

I - ¿Hay una comunicación con uno mismo?

M - Estoy pensando ( pausa). Estoy tocando para mí un determinado tema que me gusta, porque estoy en un estado psicológico determinado, y lo voy a tocar de una manera. Si estoy en otra emoción diferente, la misma obra la voy a tocar de otra forma.

Y sí, puedo tocar para mí mismo, sí.

(6)

I - ¿Cómo sería tocar para uno mismo?

M - Te sentás a tocar para vos, porque te gusta, porque querés escuchar eso, ésta obra que te gusta o la estudiaste.

I - ¿Hay una comunicación con uno mismo?

M - Sí. Podría haber un diálogo con uno mismo (pausa).

Esto que aparece en los paisajes o esta cosa que te aparece a veces cuando estás tocando que. A mi me pasaba eso como que de repente estaba tocando algo y estaba como describiendo un paisaje. Porque lo visual es algo que me gusta mucho, me gusta la plástica.

Y ahí esa comunicación era con ese entorno que el sonido me llevaba a imaginar esas cosas.

I - ¿Y en ese momento no hay nadie más?

M - En ese momento no había. Te estoy hablando de momentos así puntuales. Estaba esa cosa, ese paisaje.

I - Pero estabas vos.

M - Sí. 
(7)

I - ¿Y se puede tocar para uno mismo?

M - Sí, sí, obvio, sí. Es muy duro. A veces soy muy crítica conmigo misma, como que me cuesta un montón. Es como una persona tímida tocando para una persona... no sé si es obsesiva la palabra o como muy crítica, con bastante carácter. Entonces a veces es como una especie de miedo a mi misma.

(8)

I - ¿Y cómo sería tocar para uno mismo?

M - Y... muchísimo más relajado. A mi me pasa a veces que estoy ahí y digo "a ver voy a tocar esto" tiki tiki tiki y sale todo, y fluye todo. No importa, mucho más desprovisto de cualquier cosa.

I - ¿Te parece que de esa manera uno se puede comunicar con uno mismo?

M - Sí, totalmente. A mi me ha pasado de tener una situación que por ahí te hace poner mal, como que estás medio abatatado así por cosas del día, y como que te sentás al piano, te ponés a tocar algo y ahí como que esa emoción decanta. Como que te das el espacio para sentirte mal, tocar algo que te haga sentir mal y después llega la paz.

Hay algo psicológico que sólo se puede expresar a través de eso. Es como un canal así de apertura mental. No sé, es como raro pero bueno como que decís "somos yo y la música, y la música me devuelve esa parte de mí que yo estaba como ocultando con mil otras cosas que hacían ruido, por decirlo así de una manera linda. Es como sacarse la careta y decir "a mi me pasa esto"

(9)

I - ¿Cómo es tocar para uno?

M - Es esto que te contaba antes tal vez, de satisfacerse intelectual, emocional y físicamente. Si las tres se te dan, alguna vez, sos muy feliz. Y si sos muy feliz, ese es el objetivo a lograr.

I - ¿Hay una comunicación con uno mismo?

M - Sí. No sé como es no-comunicarse con uno mismo.

\section{Público}

El público, la audiencia, los espectadores, los que escuchan, los que miran, etc. Varias de las preguntas de la entrevista indagaban en cómo el performer entiende al público, en qué modo participa de su performance de la obra, cuál es la percepción que el músico tiene de ellos, y qué implica la situación de tocar para otros.

La percepción del público

En una performance académica, los músicos dificilmente dirijan su mirada hacia el público mientras están tocando. Algunos por elección, otros por imposibilidad. Sin embargo, el público es percibido de diferentes maneras. En estos fragmentos de las entrevistas mostramos algunos casos.

(1)

I - ¿Y los mirás?

M - Los públicos son todos distintos. No, cuando estoy tocando no. Yo los percibo, es la verdad, se percibe como una pesadez, en la atmósfera. 
(2)

I - ¿Sos de mirar?

M - No pero lo sentis, lo sentís, Pero sentís, sobre todo la energía de los que están más cerca, aunque no estes mirando te das cuenta... Vos mirás así como global y ves si se mueve el cuerpo, si no se mueve el cuerpo... la actitud, eso tambien te transmite algo, $y$ en el momento te empuja... lo mismo que el aplauso, lo que sea, pero generalmente yo soy bastante sensible al entorno en el momento de tocar, y escucho si hay conexión, y escucho si hay silencio total cuando estoy haciendo la pausa, es como que sentís que estás conectado. Ahora si escuchás ruiditos, como que la gente está incómoda, ahí yo no es lo mismo, o si hay ruido de ambiente.

I - ¿Eso pensás que te cambia un poco? Digo, si forma parte...

M - Si, sí, yo creo que forma parte.

I - ¿De qué?

M - Forma parte de la interpretación de alguna manera ese intercambio en el momento, esa vinculación con el público, sí.

(3)

I - ¿Llegás en algún momento a percibir o saber que le pasa al público?

M - En algún momento eso se percibe, sí, sí.

I - ¿Cómo?

M - En momentos en que uno hace algo que no está bien y el momento en que uno hace algo bien, por comparación. Se siente ese silencio, que están ahí, atentos. Yo lo percibo mucho eso. O momentos que no estoy bien, estoy tocando correcto digamos, y no está esa conexión, la gente escucha tocar algo correctamente bien. Con crescendos, diminuendos, stacatto, con legato. Pero hay momentos de la conexión que cuando yo lo percibo que uno se conecta ahí yo se que eso llega, y hay una...pasa algo.

(4)

I - ¿Y los mirás?

M - Cuando estoy tocando no, ni de casualidad. No puedo, porque estoy acá, el piano siempre está de perfil, nunca va a estar apuntando al público.

I - ¿Y escuchás?

M - No, trato de poner una barrera acá. Porque sino me distraigo y fui.

(5)

I - ¿Los mirás?

M - Cuando toco el piano, no. A veces me doy vuelta.

(6)

I - ¿Mirás al público?

M - Cuando puedo sí.

$\mathrm{I}-$ ¿y te influye?

M - Sí, porque ¿cómo me doy cuenta del feedback sino? Con los sonidos, pero no... Es lindo mirar.

(7)

I - ¿Llegás a mirarlos?

$\mathrm{M}$ - A veces sí, estoy tocando y veo las caras de la gente, depende con qué instrumento estoy tocando. Veo gente que por ahí me está mirando fijo, o me está mirando las manos.

(...)

No sé como sería pero lo puedo sentir mientras toco. Porque van pasando cosas en el público que a mi también me hacen tocar ciertas cosas. 
(8)

I - ¿Llegás a percibir a los demás?

M - Nosotros por la posición no miramos. Los miro antes de empezar.

Escucho cosas, generalmente cosas que te interrumpen. Una puerta, un ruido, un teléfono, alguien que habla, un bebé. Ese tipo de cosas sí. El resto no puedo! (ríe) No me da para tanta... Si, pero uno está escuchando todo. Esas cosas están ahí presentes, sí, la gente está presente (ríe).

(9)

I - ¿Estás pensando en lo que están pensando ellos?

M - Trato de que no. A veces es difícil igual. Y depende mucho del escenario, de cuánta distancia tengas con el público. Cuando vos tocás, por ejemplo, en una sala como la sala Piazzolla, que apagan todas las luces y es como que casi no existieran porque no hay nada, es re-cómodo, porque te concentrás en lo tuyo y te olvidás que hay público. Ahora, si tocás acá que estamos todos al mismo nivel, y están casi respirándote en la nuca, ahí es más difícil separarse. Lo sentís más la mirada así todo el tiempo.

Pero yo creo que en realidad es un fantasma propio porque no... Yo cuando voy a escuchar algo no sé, ni pienso en esas cosas, escucho y nada más. No me importa.

(10)

I - ¿Cómo te das cuenta? ¿los ves?

M - No, escuchás, percibís.

I - ¿Tenés tiempo para eso?

M - Si, cuando estás tocando tenés que sí. En un momento vos tenés que apropiarte de la atención del público. Porque vos lo que estás tocando en ese momento es lo más importante. Esa es la actitud, se lo merece el compositor (ríe). Sí.

(11)

I - ¿Qué sentís que recibis vos?

M - Y, la atención, vos sentís que es una retroalimentación. Es como que trasciende el silencio, esa atención.

Eso es como una comunicación porque eso a su vez hace que vos te involucres más, que te explayes o que te sueltes más. Vas sintiendo esa cosa.

O sea, está el otro, vos lo escuchás al otro en realidad. Estás como escuchando, ese silencio o esa cosa que está pasando, no estás solo, que era lo mismo que esto cuando te tirás para atrás con el instrumento, como que estás afuera. Ahí estás como dentro de ese contexto. Yo creo que uno está escuchando, básicamente escucha aunque en otro sentido, más metafórico.

(12)

I - ¿Qué diferencia encontrás?

M - Yo puedo tocar solo en mi casa y emocionarme, pero cuando hay público... Cuando hay gente escuchándote, yo también estoy escuchando al público, lo tengo presente... aunque yo no los mire, yo se que estan ahi, se que respiran... Hay una cosa que es... ya te digo, no la puedo describir pero hay como un ida y vuelta... hoy en día se habla mucho de lo energético, yo.... No sé si es así. No lo sé, pero no es lo mismo tocar solo que con otro.... Porque yo también voy muchas veces a escuchar y yo desde el lugar que estoy de oyente, a mi me pasan cosas extraordinarias. Entonces lo traslado, "bueno al otro que me viene a escuchar le debe pasar lo mismo". No soy solamente intérprete, soy músico. 
Cuando el performer es consciente de que la performance involucra tocar para otros, tiene en cuenta que el público está esperando que ocurran cosas. Es por esto que, sean más o menos tenidas en cuenta, forman parte del momento en el que están actuando.

(1)

M - Cuando yo estoy preparando un repertorio siempre pienso en la gente que escucha. Siempre pienso en la persona que escucha, si tiene formación o si no tiene formación. $Y$ el público quiere escuchar todo perfecto. Porque sino, no sería justo para la gente que escucha, que quieren escuchar lo que a ellos le gusta. Eso también, el intérprete tiene que pensar en el auditorio, esa es mi actividad personal.

(2)

I - ¿Estás pensando si están esperando algo?

M - Y, por algo vinieron a escuchar. Si vinieron por compromiso están al horno, viste. Pero la música... sino, se escucha en casa con un CD. Sale mejor eh.

I - ¿Pero te parece que tienen alguna pretensión en especial?)

M - La última vez que toqué... Es un público fantástico porque es toda gente que hace música contemporánea, gente muy formada, y yo noto que realmente lo escuchan.

Tiene que haber algo distinto a escuchar una grabación, sino no se sostiene el concepto de concierto. Es más, me molesta mucho si hay concierto con mucha... Si vas a un concierto de música contemporánea no puede haber más de cuatro obras que se estrenen. No hay atención. No es un evento que me siento... escucho un poco, me levanto, me voy.

Hoy en día hablar de cómo suena en la sala es fundamental. Es una acción, sino muere el concepto de concierto... así planteado. Entonces se supone que vienen a escuchar y si vienen a escuchar, vienen a escuchar. Sino para que están, no? Yo me he levantado de conciertos, me he ido cuando no me interesan.

I - ¿Te ha pasado que estás tocando y se va alguien?

M - Siempre pasa. Estas vueltas cuando volví a tocar no me ha pasado, viste. Sí he escuchado mucha concentración. Yo estado más concentrada o menos concentrada pero... Pero está bien que se levante y se... por ahí vieron luz y pasaron y... hay de todo, bueno.

(3)

I - ¿Qué te parece que esperan?)

M - No sé. Esperan pasarla bien, imagino. Y no se si se cumple, ese es un tema aparte (ríe). Pero imagino que uno va como cuando yo voy, a pasarla bien.

I - ¿Están esperando que vos hagas algo?

M - Sí, a ver... A mi no me importa mucho, no me influye eso, porque sino no podría tocar.

Yo fui y soy público, de muchos años. Pasa el tiempo y también, a lo largo de las edades, distintas edades, uno va con distintas expectativas o buscando distintas cosas. Así que yo sé todas esas cosas que van pasando en las cabezas de los demás. Por supuesto, las proyecto. También las escucho, porque te las preguntan a la salida. Porque los escuchás hablar, tanto de mi como cuando voy a escuchar a otros.

Hay cosas que me interesan y cosas que no me interesan de lo que van a escuchar los demás.

(4)

I - ¿Pensás que están esperando algo de vos?

M - Sí. Como que te mantengas en una línea y no bajes, o subas; pero por lo menos que te mantengas. Una línea de rendimiento. 
(5)

M - Además, ellos esperan cosas. Esperan ver una persona así, diciendo esas cosas, tocando esas cosas que ellos esperan.

(...)

Están esperando algo los otros, que pase algo. Como que están esperando que yo me comporte de determinada manera para que responda a lo que ellos quieren de mí.

\section{Tocar para otros}

Consultados por las diferencias entre tocar para el compositor, para sí mismos o el público, los músicos describieron cómo es o qué implica tocar para los demás. Ya sea que se considere como un compromiso hacia ellos, la performance involucra al público y es tenida en cuenta por los músicos cuando están tocando.

(1)

I - ¿Para quién tocas?

M - Para mí. Pero cuando toco en público me debo al público. Cuando estoy en un escenario toco para la gente que escucha, independientemente del conocimiento musical que tenga.

En los conciertos los bises los tengo pensados de antemano, pero a veces no pegan en el momento y los cambio ahí mismo.

(2)

I - ¿Cómo es tocar para otros?

M - Yo toco con mucha felicidad algo, entonces me encanta tocarlo para que los demás puedan tener la misma felicidad que tengo yo. Es así de simple. No sé si les va a gustar a todos, pero yo la transmito con muchísima felicidad, sí.

No existe la música para mí si no es para ser escuchada.

I - ¿Y los demás que están haciendo en ese momento? ¿qué te parece?

M - Yo no sé, yo trato de compartir con ellos la felicidad que me genera esa obra, lo linda que me resulta. Y yo.... Lo interesante que me parece como obra. Me parece que es importante que el otro lo escuche y lo pueda disfrutar como yo. Después ya no depende de mí. Ni de mi, ni de los que estamos tocando, ¿no?

I - ¿Cuando interpretás ante otros ¿qué cosas pensás que hacés, en ese momento, y qué cosas hacen los demás?

M - Cuando la gente va a escuchar... Entonces yo no me puedo dar el lujo de decir "hoy no le pongo nada". Por más que hay días que estoy mal o no me siento físicamente, me voy acomodando. Yo le debo respeto a la gente. Yo termino entrando en la música, es recíproco. Yo la produzco, pero la música me atrapa, viste. No sé como explicarlo. Una vez que entró a sonar te metés en el lenguaje. Sino no se podría hacer.

(3)

I - ¿Cómo es tocar para los otros? ¿se hace algo diferente?

$\mathrm{M}-$ No.

I - ¿Entonces uno puede tocar para uno mismo y además para los otros?

M - Sï. Se hace solo. Sólo ver el público y ya no sos el mismo. Sï, me predispongo en esta determinación que te hablaba, pero no lo hago de otra manera. Cuando trabajo, trabajo pensando en que es para compartirlo.

(4)

I - ¿Cómo es tocar para otros?

M - Y, tengo que saber cómo son esos otros. Quienes van a ir, quien es el público que te va a ir a escuchar, que van a esperar. 
Imaginate que voy a tocar música para niños. Va a ser muy diferente la música para niños que cuando vaya a tocar (no lo hago, pero ponele que fuera) una música política. Voy a tocar otra cosa porque van a esperar otra cosa.

Es una comunicación que se está estableciendo. Querés establecer una comunicación con toda esa masa. Tenés que pensar antes de hacerlo como para...

I - ¿Y si fuera una persona o dos?

$\mathrm{M}$ - Lo mismo.

(5)

I - ¿Cómo hacés que sea para ellos?

M - Trato de concentrarme y dar lo mejor. No es lo mismo cuando estoy tocando acá sola que no importa, no le presto atencíón. Como que cuando es un concierto me concentro y digo "te van a escuchar así que hacé lo mejor que puedas".

I - O sea que están...

M - Sí, están pero están como menos receptores de la situación. Sí, pero cuando empiezo a tocar ya me olvidé de eso porque sino no se puede.

Es como que uno ya lo tiene en el momento que te sentás decís "bueno, no estoy en mi casa, estoy en un concierto" Ahí si. Porque ¿cuál es la única diferencia? Porque vos podés estar en el mismo escenario y tocar para vos solo y no vas a tocar igual, con la misma concentración que cuando estás mostrándole al público lo que estás haciendo.

Depende del escenario además hay una lejanía o cercanía. Pero al momento de empezar sí, sabés que estás en un concierto, ahora después se te fué. Mejor, porque sino estás re-tenso (ríe).

Creo que nunca dejo de interpretar para mi sola. Para que tenga más coherencia conmigo misma lo que estoy haciendo.

I - ¿Y cuándo hay otros?

M - Algo cambia, no es lo mismo. No es lo mismo que alguien te esté escuchando que no haya nadie. Pero ahora ¿qué diferencia hay? No sé.

La comunicación con el público

Consultados por las diferencias entre tocar para el compositor, para sí mismos o el público, los músicos describieron cómo es o qué implica tocar para los demás.

(1)

I - Cuando estás tocando, ¿Te parece que hay una comunicación?

M - Siento que están interesados, atentos escuchando lo que estaba pasando. Hay un encuentro entre esa audiencia y ese intérprete.

(2)

I - ¿Te parece que hay una comunicación cuando estás tocando en público?

M - Sí. Lo que pasa es que eso es muy difícil para nosotros, los que hacemos música que guarda tantas formas. Es muy difícil, pero por supuesto que está.

I - ¿Cómo la podríamos describir?

M - Uno la siente, incluso en el silencio de los que están sentados. El silencio es muy tenso y transmite muchísimo también. Hay silencios y silencios, desde el que se durmió hasta el que está fascinado. $Y$ en el silencio también se siente.

(3)

I - ¿Hay una comunicación entre vos y el público?

M - Sí, por lo menos yo la planteo, no sé si ellos se comunican conmigo, pero yo con ellos seguro.

Mirá, es como yo te decía. Hay un aplauso... hay que manejar tiempos de pausas. 
Si tocás en un concierto en el que tocan varias personas. Te toca a vos, esperás que terminen de aplaudir, después te sentás, te concentrás, y hacés la acción que vas a empezar a tocar. Y es un aviso al otro. Que ahora empieza algo. Que antes también y que después va a haber otra obra. Entonces la acción corporal es fundamental. No puede haber ruido ni siquiera de pasar la partitura. Hay que pensar en todo. Un distractor.. Es fundamental.

(4)

M - ...como que hay un diálogo.

I - ¿Existe una comunicación entonces?

M - Sí, el emisor emite, estoy tocando. Pero el receptor por ejemplo, termina algo, empieza otra cosa, la gente aplaude, por ahí empieza a hablar un poquito... Yo de repente hago otra cosa de la que tenía pensada, empiezo asíiii que se yo, bajito y hay como una especie de comunicación. Si yo te estoy diciendo "callate la boca", ponele, bueno "arranqué, empecé a tocar" entonces estoy diciendo algo, la gente se calla, me presta atención, todo el público está así, y yo hago otra cosa, entonces es como un ida y vuelta en ese sentido. Ahí hay una comunicación digamos, clara. Pero en ese mismo nivel, con el resto de la música con la gente atenta.

Pero bueno, todo depende del ambiente, del instrumento, del piano, del escenario, si es un bar, si estoy en un teatro con la gente sentada en butacas. No sé, todo influye en la comunicación.

(5)

I - ¿Pensás que hay una comunicación entre vos y los demás?

M - Sí. Hay una comunicación, que va y que viene... pero esa obra que uno que está tocando el otro generalmente la conoce. Sabe que va a pasar y lo está esperando. Y si no lo hacés, entonces le pasa algo. Hay algo que no te puedo traducir en palabras como es. No es una presunción, algo está pasando, es una certeza que uno tiene. Pero trasladarlo a la palabra ¿cómo fue? No se puede decir. Yo tengo esa confianza que está yendo y viniendo.

\section{La devolución del público}

Además del aplauso, el performer puede recibir algo del público. Ese 'algo' puede ser percibido como una compañía o una empatía, pero también son los comentarios recibidos después de una performance.

(1)

I - ¿Qué recibís del público?

M - Es muy gratificante, la compañía es muy gratificante. Haber compartido... es lo que tiene que no tiene la grabación.

Aunque es más difícil que grato, el vértigo que se siente también es muy gratificante. Eso no lo tiene la grabación. (ríe) Cuando uno escucha grabado vos sabés que no va a pasar nada raro. Y eso no le da vida.

Todo es inesperado en el vivo, y eso está buenísimo y eso no está en la grabación.

Siempre pueden pasar cosas, desde que se muera el que está tocando hasta que pasen cosas buenísimas. Eso es lo que tiene, que es abierto, digamos.

(2)

I - ¿Sentís que recibís algo del público?

M - Sí, cuando recibis la atención, cuando se produce el silencio. Vos sabés que algo les está pasando parecido a lo que te pasa a vos. Cuando vos sentís que entregaste mucho entonces ahí hay mucha comunicación o comunión. 
(3)

I - ¿Qué pensás que le pasa a la gente cuando están ahí?

$\mathrm{M}-\mathrm{A}$ veces sí, lo pienso y a veces me lo dicen. Termino un show y la gente va y me dice que no lo pueden creer, que nunca habian visto un pianista así. O me he encontrado con gente de otros países que ... o una pianista de Suecia que justo estaba en un lugar donde yo toqué, escuchó todo el recital y me dijo que no lo podía creer, que nunca habia visto una pianista como yo "yo vivo en suecia y conozco pianistas de todo el mundo y nunca vi algo así".

(4)

I - ¿Qué pensás que piensan los demás de lo que vos hacés cuando tocás?

M - Es que no lo sé. Me encantaría saberlo (ríe).

Ya te digo, me han dicho esas cosas como "sos re vos tocando". La otra vez que toqué acá en el último concierto una me vino a decir "ay, hacés como colores en el piano, como que le buscás la sonoridad" Y yo "joya, es mi objetivo", no me gusta que suene todo igual.

\section{Presencias}

Algunos fragmentos de la charla fueron considerados aparte. Estas descripciones se diferencian de las demás porque refieren a experiencias sentidas, situaciones imaginadas, evocadas o recreadas que provocan la presencia de un otro.

En estos pasajes de la entrevista, los músicos no describen conceptualmente un encuentro con otras personas, sino que cuentan la experiencia de haber sentido estar con otras personas. Por ejemplo, no es lo mismo decir "leer una partitura es como establecer un diálogo con el compositor" que "una vez tuve una experiencia en la que hablaba con Chopin"; hay una diferencia entre una reflexión mental y una situación sentida.

Algunos de los entrevistados describen estas experiencias como un producto de su imaginación, mientras que otros ponen énfasis en haberlo vivido de algún modo. Si bien la imaginación es algo que se considera como mental, en estos párrafos los músicos hablan de situaciones que de algún modo describen como vivencias porque han sido sentidas como si fueran reales, o psicológicamente reales.

La presencia es una posibilidad

(1)

I - ¿Y en ese momento puede haber alguien más?

M - Por ahí, depende del sentimiento, si me une a otra persona puede ser. Puede ser, cómo no.

(2)

I - ¿Estás pensando en alguien cuando tocás? O solamente creés que sos vos y la música?

M - Puedo ser yo y la música, o puedo estar pensando en alguien.

(3)

I - ¿Y hay alguien más en ese momento o estás solamente vos?

M - No, está el sonido, eh. Uno es una herramienta de ese sonido. No, no, el protagonista es el sonido.

I - Pero digo, ¿aparece alguien porque te acordás?

M - No, eso trato que no. Porque perdería la concentración. Me ha pasado, de tocar en algún homenaje o eso y... Las emociones que te generan eso, perdés la concentración 
en la obra, en lo que vos querés lograr de la obra. Entonces trato de que no. Obviamente, a veces la cabeza se va, pero trato de que eso no suceda.

I - ¿Y por qué a vos te parece que uno se puede acordar de alguien...?

M - Y bueno, porque hay referentes sonoros. Seguro. Hay momentos. $Y$, porque es el tiempo, Borges decía que uno no añora los lugares sino los tiempos vividos en esos lugares. Yo creo que el tiempo es otra vez el concepto.

(4)

I - ¿No hay nadie más?)

M - Cuando estoy sola tampoco estoy sola. Quiero decir, están presentes... no sé, creo que los afectos. Los afectos de todas las personas que te rodean aunque no estén literalmente ahí. Sí, es así.

La presencia no es una posibilidad

(5)

I - ¿Estás pensando en alguien más cuando estás tocando?

M - No, soy yo y me tengo que concentrar, y tiene que salir bien. Soy yo conmigo constantemente.

I - ¿Nunca se cruza nadie, aunque sea en el pensamiento?

M - No, jamás.

(6)

I - ¿Estás pensando en alguien cuando estás tocando o solamente pensás que estás vos?

M - Cuando estoy escuchando. Puede que haya evocación de personas vinculadas. A veces me aparece una persona que no sé qué la disparó. Cuando estoy tocando no.

\section{La presencia imaginada o evocada de personas cercanas}

(7)

M - Pero de mi profesora me acuerdo siempre muchísimo que a ella le gustaba mucho cantar "da da da da" (canta). Y había toda una expresividad en los sonidos que hoy mismo tengo muy presente, todo eso inserto en todas otras búsquedas, por supuesto. Pero por momentos me acuerdo, al estar estudiando una obra, que se yo, "uh, esto mi profesora lo haría de tal manera" "acá, mirá que bueno lo que me dice ella" ¿no?

(...)

I - ¿Hay alguien más?

M - El hecho de estudiar solo te aisla.

Pero siempre cuando estoy leyendo una obra, estudiando una obra, me vienen preguntas. Por supuesto que a veces me acuerdo de mi profesora, como te decía recién, tal pasaje la digitación "ah, ella lo hacía así, claro" "¿a ver cómo era?" "tal cosa". O haberlo escuchado a Arrau, a Richter, o a Gilels, que se yo. Esto lo tocaría así tal pianista, ese tipo de cosas.

De todas maneras, no son cosas que distraen, nutren en el proceso de construcción de algo que estás estudiando nuevo. Después cuando lo tenés más asimilado...

(8)

I - ¿En ese momento estás sola?

M - Sí, a veces sí. Generalmente. Si estoy muy desconcentrada no. Si me puedo llegar a concentrar estoy como en otro lado básicamente. No sé con quien. Ni sola, ni no sé (ríe).

I - ¿Y puede llegar a haber otras personas? 
M - Puede ser. No sé. No sé cómo sería. A veces flasheo con cosas como... Yo vengo de generaciones de músicos, entonces a veces pienso como que... Encima yo sigo haciendo lo que hacía mi abuelo, entonces a veces pienso como que... no sé, como si mi abuelo estuviese ahí, como si mi abuelo también tocase. A veces lo pienso. Nunca lo dije.

1 - ¿Puede aparecer?

M - Lo que pasa es que la música es un lenguaje. Entonces es como... así como yo hablo y a veces me hago acordar diciendo las cosas como las dice mi papá, a veces me hago acordar, me acuerdo cuando mi abuelo tocaba cierta cosa, o de cierta forma, y mi papá mismo también. Con mis profesores no me pasa, ese es mi recuerdo.

(9)

M - Mozart es un compositor que yo amo pero es dificilísimo. Ahí, hay algo que a mi me pasa independientemente de la obra de Mozart que toque (que no son todas iguales). Me pasa con él que yo tengo que buscar la frescura y la naturalidad de la niñez. Eso es dificilísimo, es dificilísimo porque lamentablemente se pierde (ríe).

Entonces el trabajo es..., yo busco contactarme por ahí con... experiencias o momentos vividos con mis hijos -que son chicos-, o sino con chicos que haya conocido, pero que tengan esa edad que me retrotraen a mí a esta primera etapa de una inocencia de por ahi tocar asquerosamente pero creer que tocás lindo -hasta eso-. Ese disfrute de una enorme frescura y fluidez. Recurro mucho a ellos. En este caso me acordaba mucho de ella en algunas situaciones en que bailábamos juntas, tengo que buscar eso, es muy difícil...

Previo a entrar a la obra tengo que tratar de meterme en el cuerpo de ella, que es muy chiquita para lograr tener hasta el peso de las manos de ella. Es muy difícil. Yo no sé si lo logro, pero busco un poco eso, porque tener la mano de un niño es muy difícil.

\section{Hablando con los compositores}

(10)

M - Tengo como una anécdota, era como si tuviera... como si estuviera hablando con Schubert, me acuerdo que era un Scherzo que tocaba. $Y$ bueno, porque en ese momento estudiábamos en la facultad, en el Steinway que ya no está más, y tenía muchas obras nos pasábamos. Y era como tener un encuentro, un diálogo era, con el autor. Pero en una intimidad, una cuestión muy íntima, y muy, muy interior. Una cosa muy linda, no te pasaba con todas las obras.

I - ¿Siempre la persona que podés llegar a encontrar es él? ¿el autor? ¿o te imaginaste alguna vez que podía llegar a haber un personaje, alguna cosa así?

M - Sí, es un diálogo a lo mejor con un imaginario, que se yo, puede ser una persona que vos querés y le estás dedicando algo a esa persona. Puede ser otro pianista que admirás o puede ser otra cosa, no sé. También puede ser un paisaje.

En realidad la búsqueda mía, para mí, en ese momento era como la imaginación, ¿no? Abrir la imaginación a lo sonoro, cuando vos estás generando el sonido y lo que querés decir, la intención de alguna frase o algo y bueno, como que te abre la imaginación o vos ves un paisaje o está metido adentro de algo, o estás conversando con alguien. Esas cosas me pasaba a mí.

(11)

I - ¿Cuándo estás tocando pensás en alguien?

M - Cuando estoy tocando música de tango se me cruza Gardel. Cuando estoy tocando música de Chopin, se me cruza también. Uno parece que lo viera, sentado con la George Sand ahí lo más tranquilo tomando un café en su casa, y oyendome. Una cosa 
que uno a veces está compenetrado con todo. Porque uno a veces completa todo con la biografía del autor también.

(...)

I - ¿Qué le dijiste a Chopin?

M - Lo de Chopin fue gracioso. Porque yo una vez estaba tocando una balada, no me acuerdo cual. Y vi una cosa disonante, entonces sufrí como una especie de ensoñación cuando estaba tocando el piano. Y entonces vi como si fuera un túnel, así. Y acá, en la boca del túnel estaba George Sand con un vestido gris de volados, al lado de un piano de cola con una manta roja. Y Chopin estaba así apoyado, Chopin que tenía el pelo asi y así, como esa foto... una de esas últimas. Y yo no podía pasar, era como si me hubieran parado ahí, no podía entrar en la habitación, me quedaba ahí. Y yo le dije: “¿me quiere hacer el favor de decir por qué puso esa nota ahí?" Y el tipo se moría de risa. Estaba tocando el piano. Tuve una visión. 


\section{APÉNDICE 2}

\section{Entrevista 2}

\section{Guión de la entrevista}

1. ¿Qué es lo más importante para llegar a interpretar una obra?

2. ¿Piensa que hay una sola manera de tocar una obra?

3. ¿Y cómo procede para saber cómo debería tocarla usted?

4. ¿Usted tiene una sola manera de tocar una obra, ya sea porque es el ideal de su objetivo o el resultado al que llegó con su versión definitiva?

5. ¿Y qué piensa que tiene usted para aportar desde su interpretación?

6. ¿Cómo se siente cuando toca?

7. ¿Cómo se diferencia de cuando está haciendo otras cosas en su vida cotidiana?

Pienso que hay algo particular que lo diferencia de las demás cosas, algo que hace que uno regrese y vuelva a tocar... ¿Por qué cree que vuelve al instrumento a tocar?

8. ¿Piensa que de alguna manera es otro/a cuando está tocando? ¿O se siente diferente de algún modo?

9. ¿Está pensando en alguien cuando toca o solamente está usted?

10. ¿Y usted en dónde está? ¿Cómo se ubica con respecto a la música?

11. ¿Piensa que, de alguna manera, hay otros/gente/personas en la música?

12. ¿Cómo definiría quien es usted con respecto a la actividad que realiza? ¿qué otra cosa podría ser? ¿sería posible compararlo con otras actividades de otras personas?

13. ¿Qué cree que piensan los demás de lo que usted hace cuando usted está tocando?

14. Durante la interpretación ante otros ¿Qué cosas cree que hace usted y qué cosas hacen los demás?

15. ¿Cómo piensa que se sienten ellos cuando interpreta? ¿Suele pensar en eso? ¿mientras está tocando también? ¿Los mira cuando está interpretando? ¿Lo influye? ¿Y qué le pasa en ese momento? ¿Y antes de tocar? ¿Y después?

16. ¿Siente que recibe algo del público? (además del aplauso)

17. ¿Piensa que existe una comunicación entre usted y ellos? ¿Cómo sería?

18. ¿Existe algo que comunicar? ¿qué es?

19. ¿Y a quién le pertenece ese algo?

20. ¿Cómo le parece que a música se vincula con el tiempo? ¿Ese tiempo de la música es diferente al de la vida cotidiana? 
21. ¿Cómo organiza su interpretación de la obra en el tiempo?

22. ¿Cómo se siente cuando está dentro del tiempo musical? ¿considera que es su tiempo o es el tiempo de otro? ¿es un tiempo compartido o es un tiempo personal? ¿y cómo se da cuenta?

\section{Temáticas del análisis ${ }^{80}$}

\section{La interpretación}

La temática de la interpretación se organiza en cinco sub-temáticas. Los músicos respondieron acerca de: (i) aspectos importantes en la interpretación; (ii) la posibilidad de una interpretación única vs. la interpretación personal; y (iii) la de una interpretación ideal, así como (iv) el modo en que piensan la interpretación.

(i) Lo más importante

(1)

I - ¿Qué te parece que es importante para llegar a interpretar una obra?

M - Lo más importante - bueno, es una expresión pero, que encierra muchas cosas, no sé si podría precisar en su totalidad- es lograr que esa obra, respetando todo lo que está en el papel, respetando sabiendo que lo que está es de una enorme amplitud de lectura, uno es consciente de eso. Pero respetando lo que está uno pueda hacer de esa obra que sea suya, esa sensación que uno la puede hacer como si hubiera salido de la cabeza de uno, no que es mía, que uno la pueda hacer con esa frescura, no actuarla o sobre-actuarla, recuperar eso. Si uno logra eso en una interpretación es muy placentero, se siente muy feliz. Creo que uno tiene la sensación de que logró algo, de que hizo algo bueno porque uno no siente que está artificialmente tocada.

I - ¿Hay una manera de hacerla tuya?

M - Sí, es larguísimo. Es hacerla... Cuando uno dice "hacerla suya" es intelectual, emocional y físicamente suya. Sentir que la obra fluye, que uno no está forzándose a tocar pasajes que no entendés ni para donde van, que los pasás porque no sabés bien qué hacer. Es muy difícil, creo que no se si uno tiene alguna vez -uno, no digo los grandes-, esa sensación que de principio a fin uno la abarcó pudiendo lograr eso. Pero ese es el norte.

Pero ya te digo, es intelectual, emocional y físicamente, uno siente que fluye, que de principio a fin es coherente, que hay armonía, que la pudo abarcar, que no queda entrecortada o partimentada, que uno logra integridad en los tres niveles, y eso es muy complejo.

(2)

I - ¿Qué te parece que es lo más importante para llegar a interpretar una obra?

M - Entender, si es un mensaje el que hay, cuál es. Porque yo creo que, no sé, la música transmite una idea, entonces hay que descifrar cuál es la idea que el tipo que escribió eso o la mina quiso plasmar en la música. Me parece que por ahí va la cosa.

(3)

I - ¿Qué te parece que sería lo más importante para llegar a interpretar una obra?

${ }^{80}$ En las transcripciones, las iniciales que se presentan antes de los diálogos identifican al entrevistador y al entrevistado entendidos respectivamente como investigador (I) y músico (M). 
M - ¿Tenés tres meses para hablar de eso? (ríe) Yo creo que lo que se ha perdido hoy es narrar historias. Se está muy en función de tocar muy bien el piano, de ser muy virtuoso pianísticamente. Hoy ya está todo codificado, digamos, lo que son los crescendos, los diminuendos, ponés Youtube, tenés veintiocho pianistas, por decir un número apenas, que tocan la sonata tal y cual, y tenés una idea de cómo hacerlo, digamos. En otra época no teníamos el Youtube y era otro tipo de elaboración.

Pero me parece que lo que se ha perdido es un concepto de lo poético, que es lo que yo siempre escucho en esos grandes pianistas del pasado. En un Arrau, en un Richter, Guilels, ¿no? Tatiana Nikolayeva, que la encontré hace poco, es una belleza haciendo Bach tremenda, Porque no hacen fortes o pianos, crescendos, te estan contando, hay algo detrás de todo eso, que eso es lo que uno trata de rescatar, en principio. Hay un punto ahí.

(4)

I - ¿Qué sería lo más importante para interpretar una obra?

M - Sentirla, yo creo que sentirla. Uno, una obra la toca cuando la siente en la yema, cuando vos sentís que tu yema es la que genera ese sonido.

No es tan filosófico, es cuando vos sentís que realmente la yema del dedo está generando ese sonido. Porque hay todo un mecanismo, pero en el fondo... y que hay una conexión muy fuerte con el que escucha. Es una construcción colectiva de lo que vos le das y lo que recibe el otro.

(5)

I - ¿Qué es lo más importante para interpretar una obra?

M - Es importante entender lo que el compositor quiso decir.

I - ¿Es solamente lo que quiso decir el compositor?

M - No, yo también quiero decir lo mío. Es una transmisión al auditorio, a la persona que me está escuchando. A la persona le llega o no le llega la música.

$\mathrm{I}-$ ¿Y a quien le pertenece eso? ¿es de alguien?

$\mathrm{M}$ - Yo lo tomo y se va al auditorio. Yo lo hago y el otro recoge las cosas que yo hago. Yo le pongo cosas. Y del compositor le pongo un poco de lo que hizo. Le puedo modificar algo pero sin sacarle la esencia, entonces llega.

I - La otra vez me decías que el intérprete recreaba la música...

M - Claro, agarra la obra, se la hace propia, sin cambiarle la parte técnica. En lo clásico uno recrea la parte expresiva, porque a veces en la partitura no está todo escrito. El intérprete lo que hace es... recrea lo que hizo el autor.

Cuando uno escucha a un buen intérprete, que es maravilloso, uno ve la música escrita de acuerdo a lo que ellos tocan. Parece que escribieron lo que ellos están tocando, no que están tocando lo que está escrito.

I - ¿Y cuando estás trabajando, en ese re-crear la obra es siempre la misma? O cambia?

M - Y sí, cambia. Hasta que vos encontrás el lugar exacto. A veces uno lo cambia, pero muy poco. Cuando tengo que tocar delante de la gente agarro una de las cosas que he hecho y lo pongo ahí. La obra siempre está escrita, lo que uno hace es recrearla, sin salirse de lo escrito. Modificarla no.

(6)

I - ¿Qué te parece que es lo más importante para interpretar una obra?

M - Lo más importante es tener la expectativa, que yo más que expectativa diría "duda". Qué duda hay antes de comenzar a ejecutar una obra para comunicarla, porque sino ¿para qué va a ser? ¿no es cierto? Podría añadir teorías, que se yo. Te podrías estar comunicando con el autor, ¿no? A mi me suena medio extraño. Prefiero comunicarme con el público aunque esté solo. Parece un contrasentido, pero esa es la expectativa: ¿qué comunicaré?, aunque sea a mí mismo. Por eso te digo, aunque esté solo, siempre hay "otra cosa" a quién comunicar, sino ¿para qué? ¿para vender libros? 
¿para vender discos? ¿para vender cintas? ¿para vender no sé qué medio se inventará? No es para vender, es para comunicar. Y siempre que quise comunicar algo, tenía la expectativa. El problema fué a veces conseguir la expectativa del otro. $Y$ la misma longitud de onda. Esto es quizás lo más difícil. Me refiero a que la persona a quien supuestamente estás dirigiendo un mensaje está esperando otro mensaje, y de otra fuente, o de otra característica, o en otro idioma si vos querés. Yo puse longitud de onda, buscá vos qué término usar, no sé. Yo te lo digo porque me surgió así.

Cada vez que uno quiere comunicar algo -yo te hablo de mí-, no quiero comunicar una cosa, sería el contrasentido de la expresividad. Si yo estoy seguro de qué quiero comunicar... y, me pego un tiro. Porque no quiero comunicar nada. Estoy, además, despreciando al destinatario de esa comunicación; estoy pensando que él va a recibir eso, y que lo va a valorar, y que le va a hacer falta. Es una estupidez.

Es lo mismo que el acto docente, eh. Instrumento por medio, la docencia por medio, es lo mismo, absolutamente igual.

(7)

I - ¿Qué te parece que es lo más importante para interpretar una obra?

M - Vos podés escuchar versiones por ahí.. Que no dicen nada, y versiones como la de Julian Bream, por ejemplo, y vos las ponés, las estudias y por ahí habría alguna cosa que podría ser distinto pero creo que no hay ninguna duda que la versión convence ¿desde qué lugar convence? Yo creo que desde este lugar que vos escuchás como una continuidad en la expresión... como un actor ¿no? Que vos mirás y decís "esto está bien actuado, o mal actuado" Y lo escuchas forzado. Con la música pasa así, en general.

\section{(ii) ¿Una sola manera? Buscando una interpretación propia}

(1)

I - ¿Te parece que hay una sola manera de tocar una obra?

M - No. Hay que probar varias. A distintos ritmos, y en distintos carácteres. A distintas velocidades.

I - ¿Cómo hacés para saber cual es la que es para vos, la manera de tocar tuya?

M - Y, ahora es más mi intuición en este momento. Me dejo llevar.

(2)

I - ¿Pensás que hay una sóla manera de tocar una obra?

$\mathrm{M}$ - No, para nada.

I - ¿Cómo hacés para saber cuál es tu manera para interpretar esa obra?

M - Uso algunas herramientas. Me grabo la obra, filmo, me grabo para escucharme, para escuchar el sonido, o con el piano era lo mismo, para escuchar la sonoridad. No sé, voy viendo el tempo, a veces dice lento pero ese lento no te significa nada, o vos necesitás que sea un poco más rápido.

Eso sí, es una búsqueda pero de mi propio timing, que soy como una persona así ansiosa y por ahí no me banco mucho las cosas lentas, o no suena a veces.

Y bueno, voy buscando hasta que uno ... es como una cosa como que lo encontrás pero tiene que tener una fundamentación más que esto que estoy diciendo. Es una búsqueda que vos sentís que bueno: ahora sí.

I - Hasta que llegás a un momento en el que ya lo encontraste digamos.

M - Sí. O sea, tampoco eso es un absoluto porque es el día hoy me pasó esto, suponete. Ahora te hablo desde el piano. Por ejemplo, cuando tenía una obra resuelta, bueno ¿qué hacía? Venía, me sentaba, tocaba y a lo mejor había logrado en ese momento algo que me sorprendía y me interesaba mucho, una cuestión expresiva. Y bueno, en ese momento era esa, esa forma. Después por ahí te sale más rápido. 
(3)

I - ¿Te parece que hay una sola manera de tocar una obra?

M - Jamás. No. Creo que nadie podría pensar eso igual.

I - Entonces ¿cómo hacés para saber cuál es la manera en la que vos deberías tocar una obra?

M - Con la que mejor me conecte, digamos. Con la que no.... No se. Como que no pensar en nada más que en lo que va a sonar. No pensar ni en dedos, ni "este pasaje no me sale". Es como sólo concentrarte en la música y lo que está sonando en ese momento. No controlar más que eso.

Me ha pasado de agarrar una obra que toqué cuando iba al conservatorio y era una piba. Y claramente había un montón de cosas que no le estaba sacando el jugo pero iporque no las entendía!

I - ¿Y cómo hacés para entender entonces?

M - Y, como que te cae la ficha de... no sé, porque te faltaba información de lo que era la tonalidad, lo que no era la tonalidad, o que esto tenía que conducirse hasta ahí porque te llevan un montón de cosas. No sé, son como cositas que lo hacías porque te decían o porque el instinto te llevaba a hacerlas, y ahora que lo entendés lo podés explotar mucho más. Podés elegir hacerlo, no hacerlo.

I - O sea que tenés opciones para elegir...

M - Sí, mil! Pero siempre el instinto tiene que estar. Si vos no tenés como una cosa interna que lleva a hacerlo de determinada manera no va a funcionar.

(4)

I - ¿Hay una sola manera de tocar una obra?

M - No, ojala que no! (ríe).

I - Y entonces ¿cómo sabés la manera en que vos tenés que tocar una obra?

M - Lo que podemos decir es que hay marcos estéticos globales sobre los cuales uno plantea, ¿no? Que también es una cuestión muy relativa, porque vos el Bach que hace Gould y el Bach que hace Rosalyn Tureck pedaleado y ¿quién tiene la verdad? Y los dos son maravillas por diferentes motivos.

Hay como grandes marcos sobre los cuales trabajar. Determinado tipo de fraseo. Después está la cosa de que somos seres humanos, tenemos diferentes estados de ánimo aún por nuestra concepción de multiplicidad de yoes que nos construyen, entonces no estamos siempre de la misma manera.

(5)

I - ¿Hay una sola manera de tocar una obra?

$\mathrm{M}-$ No.

I - ¿Y como vas haciendo para encontrar tu manera?

M - Es esto que te digo, darle forma y que eso cierre, es que cierre en ese sentido. Lo que estoy pensando de la obra, lo que estoy sintiendo de la obra y luego obviamente lo que estoy sintiendo físicamente de la obra porque la tengo que hacer. Que es lo más difícil porque leerla y emocionarte con la obra te podría decir que es más fácil. Luego hay que hacerla a la obra y eso es... ahí hay que pensar también en frío.

(6)

I - ¿Te parece que hay una sola manera de tocar una obra?

$\mathrm{M}-$ No.

I - ¿Cómo hacés para saber cuál es tu manera?

$\mathrm{M}$ - Y, es donde yo me sienta cómoda.

Está bien, investigar un poco al compositor es parte de eso para entender un estilo.

Depende de qué música estemos hablando. Entender un poco el estilo y entender qué articulación corresponde, que onda le vas a dar a... cómo lo vas a estudiar... 
Pero bueno, obviamente siempre hay que tomar una decisión y esa decisión te hace.. Hace que vos le des tu personalidad a la música.

(7)

I - ¿Hay una sola manera de tocar una obra?

M - No. Para nada.

I - ¿Cómo hacés para encontrar tu manera?

M - Para mi es muy importante el evento en el que.... Yo estoy pensando en tocar la obra para otros, ¿no? El lugar, la espacialidad donde vos vas a trabajar, como influye en nuestro caso aparte el piano, cuál es la característica del evento, cómo está construído el programa, en qué lugar tocás, después de qué obra y antes de cuál, qué gesto vas a tener que generar si el público es muy disperso y vos tocas una obra con pianissimos, donde sino se sostiene el sonido no se dice nada, por ejemplo. Y depende de cómo uno esté también.

(8)

I - ¿Te parece que hay una sola manera de tocar una obra?

M- No. Sino, yo no distinguiría una Argerich de un Barenboim.

I - ¿Cómo hacés para saber cual es la que es para vos, la manera de tocar tuya?

M - Porque la intencionalidad... digamos, vos bajás la nota que está. Vos la bajás fuerte, piano, como te van pidiendo. Pero cuán piano, cuán fuerte, o el contenido que vos le ponés a esas notas no es el mismo que le puso el otro. Aunque si la estudias con un maestro te va a dar... toda su visión de la obra. Pero después hay un punto en el que vos empezás a reinterpretar la obra, no desde tu punto de vista, desde tu emoción. Entonces la vas cargando de un montón de significados que hacen que vos bajes un poquitito diferente de lo que baja cada uno. ¿no? O que le pongas un poquito más de peso... todo eso se traduce y no hay forma de... todo eso se traduce al sonido. jno hay forma de explicarlo en palabras! Para mí. Y si buscás la forma es como: "¿para qué vamos a destruir este misterio?”. La palabra, al menos en música, no llega a narrarte la emoción. La emoción es la emoción.

(9)

I - ¿Te parece que hay una sola manera de tocar una obra?

M - No creo. No, no. Hay varias. También depende del que toca. Y si la siente así o no la siente así de acuerdo a lo que debe ser. Eso es lo que yo pienso.

I - Entonces ¿cómo hacés para saber cuál es la manera en la que vos deberías tocar una obra?

M - La mía personal es cuando uno se acerca y tiene, por ejemplo, una afinidad con lo que está escuchando.

(10)

I - ¿Te parece que hay una sola manera de tocar una obra?

M - No. Sería como comprar un cuadro y por un rato mirarlo, ¿para qué lo comprás? Pasás por la exposición, lo mirás y listo. Una obra es un cuadro que lo vas a ver todos los días. Y lo vas a disfrutar todos los días. Y sino, tenelo enmarcado y dado vuelta, o enrollado, viste.

Y de todos los días implica -en lo que vos preguntás de las obras-... Hay una diferencia, una cosa es cuando vos tocás solo y cuando vos tocás en la orquesta y tenés una parte solista o integrada a un grupo, es muy diferente. En ese caso vos vas a hacer tu parte, tu partichela lo mejor que puedas, pero el que está expresando es el director. Vos te asociás al director. Así como el director se asocia al compositor. Al compositor y al público. En cambio estando solo, es directa, el pasaje es directo. Entonces, nunca la toco de la misma forma, sino me pegaría un tiro, o rompería la obra, o rompería la guitarra, el piano o lo que sea. 
(...)

Yo nunca podría tocar una obra una sola vez. Para eso, dado el sistema de estudio que te dije, directamente no la estudio, no la toco, no pierdo el tiempo, ni le hago perder tiempo a otro, menos al compositor, pobre. Porque por ahí no la entiendo a la obra, no la decodifico. Entonces por qué la voy a manosear, no?

(...)

No hay una sola manera, es infinita. Por eso una obra, a veces uno le dice al alumno, "mirá, dejala un tiempo, dejala que madure un tiempo (ríe), ponela en el asiento y que madure". "No, se me gastó". No, no se gastó, necesita tomar una maduración que no tiene, y que no tiene uno. Pasa con los libros, uno no los lee, los tiene gastados de volver a leerlos. Porque cada vez que los vuelve a leer le encuentra una dimensión que no le había encontrado. Y una significación que no había tenido. "iUy qué bárbaro ésto!" y ahí lo archivo. Entonces a veces por ahí pasa mucho que desaparecen libros más vale- $y$ uno los va a buscar porque decían tal cosa y no los tenés. Y con las obras pasa lo mismo. Aunque sean muy sencillas, pero querés sentir esa combinación de sonidos, cómo la hizo el autor, y es muy elemental, muy simple técnicamente pero es lo que yo necesito en ese momento. Para ser "yo músico". Para expresarme a través de eso. Porque es elemental, así como el escritor, a través de lo escrito, y el pintor a través de sus formas y sus colores, el músico también necesita esas formas y esos sonidos para poder hacerlo. O sea, el músico no es para hacer plata con eso, ser conocido por eso, ser aplaudido, ser famoso. Son diferentes cosas, en éste mundo confuso, en ésta época donde está confundido lo que sea comunicación artística con espectáculo, por ejemplo.

Yo todo lo que veo es un espectáculo. Van al cine, van a ver un espectáculo. Van a un concierto, van a un espectáculo. No van a tener una comunicación. Desgraciadamente lo veo así.

I - Entonces ¿cómo hacés para saber cuál es la manera en la que vos deberías tocar una obra?

M - ¿Vos sabés Matías que no? En primer lugar, uno escucha diferentes ejecutantes pero si son expresivos para uno. Y cada uno es expresivo a su manera, y porque es diferente. Cada ser humano es diferente. Entonces eso volcado a uno mismo, yo mismo, no me hace falta buscarle a la obra como mejorarla, como hacerla más linda, como más atractiva. No. La obra me va sirviendo a mi.

(11)

I - ¿Te parece que hay una sola manera de tocar una obra?

M - No. Está a la luz de las diez millones de interpretaciones que la obra pueda tener. Probablemente para uno termina cerrando de una manera o tiende a acercarse a una manera de tocarla que es la tuya, un poco.

I - Entonces ¿cómo hacés para saber cuál es la manera en la que vos deberías tocar una obra? Un poco ya lo hablamos...

M - Si, en principio me guío mucho por la cuestión intuitiva, emocional. Decir "me gusta" llevar la obra para este lado. Me gusta, me convence... Siempre a mi me gusto, aún dentro de este concepto de "libertad" que estaba diciendo, tratar de ser fiel al estilo igual. Creo que eso no se contrapone. Uno puede tener libertad tocando Bach y de repente estás decidiendo .... Son cosas que definen muchísimo la sonoridad y todas son en el estilo. Tratar de ajustarse a esa sonoridad del estilo.

I - Sí, lo que más me importa es ver si vos llegás a construir una intención que reconocer como propia, ¿no?

M - Sí, yo creo que dentro de este concepto de "libertad". Yo te digo libertad y en realidad es como una especie de fidelidad a uno mismo, de hacer las cosas con convicción y a fondo, y que todas las notas tengan un lugar en la interpretación, que tengan una función, una manera de decir. Que uno nunca toque las notas sin saber cómo las está tocando. 


\section{(iii) La versión ideal}

(1)

I - ¿En algún momento llegás a crear como una especie de versión ideal de la obra?

M - No sé si versión ideal, pero que tenés un imaginario sí. Un deseo de cómo quisieras que suene, sí. Pero no sé si uno, cuando te sentás a tocar, no sé si cumplís con ese ideal como cosa así absoluta. No sé. Pero bueno, que se acerca o que te gusta lo que hacés, sí.

Un día te sale fantástico. Y sí, te queda ese recuerdo. Tiene que ver con la entrega de uno también, con el momento en que uno está y con la entrega que uno hace en esa cuestión de la comunicación.

(2)

I - ¿Hay una sola manera, un ideal de tu manera de tocar la obra?

M - Depende del día (ríe), la situación. No es lo mismo cuando estás tocando en tu casa que cuando vas al concierto. Depende el día, lo que te va pasando, por ahí estás medio acelerado, se te acelera. Va mucho con el diálogo interno que uno tiene en el momento que está tocando.

I - O sea que vos tenés como una gama de posibilidades.

M - Sí, y el dicho ese de "hay que prepararse para cien y que te salga sesenta" más o menos, para mí es una realidad.

I - Cuando estudiás, ¿preparás diferentes maneras de tocar?

M - No, yo siempre sé cuál es mi máxima y trato de mantenerlo ahí. Después en el vivo puede pasar cualquier cosa.

Cuánto más veces lo tocás empezás a descubrir más cosas. Por ahí las primeras veces estás más pendientes de la digitación o "ay, acá no te apures" o "acá esperalo", "escuchalo". Pero después como que lo hacés más carne y va fluyendo. Capaz que decís "ahhh esto era asi" "ahhh acá estoy imitando" "acá tengo que hacer tal cosa". Como que te desligas más de lo técnico y pasás a hacerlo más natural, si se quiere.

(3)

I - ¿Llegás a una versión ideal? A decir: "Ésta es mi versión"

M - Ah no ¿mi versión? ¿ldeal de lo que quiero? Si. Pero de mi versión nunca tengo un ideario.

Uno corrige, es curioso eso, porque uno trabaja mucho tiempo una misma obra, te diría que hasta que te ponen la fecha para tocar, no es como cuando uno tiene que rendir un examen. Sino, es infinito. Entonces hay todo un trabajo casi, no diría una lucha, pero es un trabajo de concesiones. Y uno corrige todo el tiempo, uno siente progresos, y son permanentes por eso te digo que si uno no pone un punto o un punto aparte no tocás nunca. Porque todo el tiempo se corrige, y se corrige, claro, con respecto, pienso yo a una idea que uno tiene. Una idea, nunca pienso en que es una intelectual, pienso en una idea emocional también, juntas.

(4)

I - ¿Llegás a una versión ideal de tu interpretación?

M - No. A veces pienso cosas así, pero después modifico constantemente las cosas. Porque siento que los lugares... como que la música, más allá del papel, es la gente que está alrededor, es el espacio. Es el escenario, es el piano en particular, entonces es como que... cambia. Y una misma obra a veces es muy diferente, no por mí sino por el receptor. 
(5)

I - ¿Tenés un ideal al cual llegar o construir "la" interpretación de la partitura?

M - Depende de lo que vos toqués. Yo ya tengo un objetivo. Quiero lograr esto. Quiero lograr que esto impacte en tal lugar. Y ver cómo lo hago, para que pase.

I - ¿Y si no pasa?

M - Y si no pasa, en el momento en el que estoy tocando lo arreglo.

I - Está bien, como que lo vas llevando.

M - Sí, sí, sí.

(iv) Pensando la interpretación

(1)

I - ¿Cómo vas preparando la interpretación? ¿Qué cosas vas haciendo?

M - Bueno, en mi caso, por el tipo de práctica siempre es desde el papel. Inevitablemente empieza en el papel. Pero siempre intentando también que suene algo. Creo que rara vez, nunca me he sentado con el papel fuera del instrumento. Si lo hice lo hago, al contrario, en situaciones ya avanzadas de la obra, pero sino quiero que esté sonando algo, necesito que esté sonando algo. La lectura silenciosa es difícil -depende de la obra- pero siempre es en el instrumento. Y luego es una dinámica de ida y vuelta permanente, del sonido al papel, del papel al sonido. Los dos están todo el tiempo retroalimentando el trabajo porque renuevan permanentemente la "visión" entre comillas que uno va teniendo, la concepción que uno va teniendo. Pero es ese trabajo. Por supuesto que cuando uno conoce al autor, eso ya viene predispuesto de ideas y de expectativas sobre la obra. No es lo mismo cuando es desconocido. Pero cuando es desconocido es cuando más iría al instrumento, y probaría encontrar, darle forma, siempre buscando un poco eso, la sensación que tengo es siempre buscando darle forma. Ir a lecturas extra, intertexto ese tipo de cosas, por supuesto que hago uso de eso, o cuando la obra es demasiado intensa o por curiosidad a veces. Las curiosidades que tienen que ver con las anécdotas, que tienen que ver con el autor o lo que le habría pasado no sé hasta qué punto aportan a la interpretación de la obra que tengo ahí en el papel. Eso es más de color, más divertido, Sino el trabajo es desde el papel.

(2)

I - ¿Te conectás con el compositor cuando trabajás con la obra?

M - Sí, en ese sentido te conectás, pero bueno la lectura es indefectiblemente propia. Yo trato de ser respetuosa porque la obra no es mía, pero no puedo ser él tampoco (ríe). Con "hacerla mía" es ser muy respetuoso de todo eso anterior. "Hacerla mía" en el sentido que fluya, de que no sea sobreactuada digamos como esas recitaciones de poemas infantiles viste "en el cielo las estrellas" y es un espanto, porque no suena nada.

Bueno buscar eso, que sea fresco, que sea natural y bueno para eso tenés como que encarnarlo. Pero no es que es mía porque la idea es mía digamos. Ahí voy cuando digo que tengo que ser respetuosa porque no puedo inventar, tengo que recrear.

(3)

I - ¿Cómo llevás adelante la preparación una obra?

M - Cuando estudio me busco varias posibilidades. Porque no se como va a pintar arriba del escenario, como va a salir disparado. Después que toco el primer sonido... Es así, yo voy con una idea. Es como tener un bagaje de cosas, y entran a salir. Pero si el discurso salió de una forma... eso es lo que me va pre-determinando qué buscar. Puedo hacer un parate en una frase donde no lo hace casi nadie o a veces voy con el imaginario de cosas que escuché, que me gustaron mucho.

Siempre estoy como reinventando algo. Reinventar no quiere decir que vaya a hacer algo nuevo, pero decir: "ahora estos días lo voy a tocar así que me gusta más". 
(4)

I - Y una vez que ya empezás a tocar la obra, ¿cómo le vas dando forma, o cómo se va trabajando?

M - Según la expectativa, ahí ya es mía, ahí ya empiezo a disfrutarla. Es como disfrutar un hijo. No es lo mismo disfrutarlo recién nacido que a los dos años, que a los tres años. Él va cambiando, le estás dando posibilidades de que cambie, de que mejore. Entonces, cada vez que la ejecutás, esa es la gran expectativa y el interrogante, ¿no? “¿cómo me saldrá?", "iuh, me equivoqué de dedo!", eso es circunstancial. Una pifiada de dedo, "se me cayó la batuta".. Y no se para la orquesta si es tú orquesta. Con la guitarra, con lo que sea, pienso que no es lo más importante. Aún desde el punto de vista expresivo, no creamos que siempre va a salir mejor o diferente. Hay veces que uno no está, y desgraciadamente, te voy a decir Matías - a lo mejor vos ya lo sabés-: hay veces que uno no está en toda la obra iy son las veces que más te aplauden! (ríe) O sea, lo más divertido, es decir ¿cómo estos salames me vienen...? ¡Yo los tenía por ídolos! Porque había que hacer un esfuerzo para que te aplaudieran, para arrancarles un aplauso. ¿En éste momento que yo no dije nada me están aplaudiendo!? ¿qué aplauden? Mi ignorancia, mi ineptitud, mi silencio. (ríe) Eso es lo divertido.

(5)

M - Este hombre me acuerdo que insistía para que no toque plano, siempre al mismo nivel. Sin darme demasiados recursos. Pero esa insistencia fue generando algo y me terminé acostumbrando a jugar. Que jueguen con la música, que se diviertan.

Con este hombre lo que fui aprendiendo fue eso. Es algo que me permitió eso de... Del interactuar con otra persona y ver los momentos en las obras. Hacer música desde un lugar más intuitivo. La capacidad de disfrutar algo con cierta libertad.

I - Te tengo que preguntar de la "libertad" entonces, ¿qué sería la "no libertad"?

M - (piensa) Bien, bien, bien. La no-libertad sería hacer algo porque "se tiene que hacer". Porque me lo dijeron, porque lo vi en una versión. No porque uno está convencido de que se debe hacer de esa manera. Entonces eso sería la libertad. Entonces yo siempre me consideré un intérprete libre, y he huído de situaciones que intuís "acá no voy a tener tanta libertad".

Básicamente creo que sería eso: el músico tiene que ser libre, el artista tiene que ser libre para que funcione, porque justamente la comunidad de artistas se nutre de la libertad de cada uno de los artistas, y entonces es ahí donde la cultura se... ¿no? Se da como ese intercambio. Pero si yo hago algo pensando en lo que me va a decir ese, o lo que dijo, o la versión... Yo escucho una versión por ahí para ayudarme a entender una obra, para "ah, esto funciona de esta manera", pero no para decir "esto hay que hacerlo de esta manera".

(6)

I - ¿Cómo se prepara la interpretación a partir de la partitura?

M - Entonces si hay una versión que está circulando, que está dando vueltas... ¿no? Está circulando, te llega. Por ahí es lo mismo. Dependerá seguramente del estilo, porque no es lo mismo si abordás una obra que por ahí es de Bach... y, vas a estar prestándole atención a otras cosas, tratás de entender los motivos, tratás... No todas las músicas tienen el mismo tipo de trabajo... intelectual. Analizás los motivos, sí o sí. Es saber justamente como decirlo, tenés que saber cuáles van a ser las estructuras. Pero de repente agarrás una obra de Tárrega y es más directo.

Entonces, bueno, esto que te decía, ver el carácter o el concepto de la obra. Tratar de saber hacia dónde tenés que llevar la obra que es por ahí de lo más importante... O sea, tenés que tener claridad de cuál es el concepto así general de interpretación de eso que estás tocando. Como que si tenés claro eso te permite avanzar en la interpretación que termine funcionando. 
(7)

M - Es necesario que el intérprete trate de comprender... o parte, porque está bueno que el intérprete... hay cosas que surgen distintas, por eso también está bueno esto de la libertad del intérprete pero... de comprender la obra, como sea, desde su mirada. Porque vos podés hacer una escultura, y por ahí el que la hizo le puso énfasis en determinado detalle y capaz que viene uno que la mira y dice "mirá que bueno esto, esta cara que tiene" y capaz el otro no le había prestado atención. Yo creo que eso también pasa cuando uno hace algo musical, y pasa eso, otra persona... O sea, yo no creo en esto de la obra, que se mantenga... desde el momento que otra persona la mira ya (aplaude), o sea se está modificando, es imposible que sea la misma obra que la que pensó la persona, el compositor, que sea la misma obra que el que interpreta. Seguramente va a haber una variación, porque es otra mirada y eso modifica.

Me parece que el que está al frente de la interpretación tenga esa libertad para... Y es eso, como que de repente la obra va teniendo como distintos aspectos, y es la misma obra. Eso también está bueno, como la obra puede... la misma obra, o sea, sigue siendo la misma obra pero tiene como distinta forma.

I - Si. Aparte esto que decís de la escultura es genial, porque es como una escultura de sonido, y que vos si lo mirás desde otro punto de vista es como que...

M - Claro, donde ponés el ojo viste... donde ponés... o el oído...

\section{La performance}

La comunicación en la performance fue indagada a través dos preguntas centrales: (i) ¿qué se comunica en la performance?; y (ii) ¿a quién le pertenece lo que se comunica?. Luego, encontramos segmentos de la entrevista sobre la relación con el público, la obra y otro tipo de ocurrencias en la performance.

¿Qué se comunica en la performance? ¿A quién le pertenece?

(1)

I - ¿Existe algo que se comunica en la performance de la música?

M - La parte expresiva.

I - ¿Y a quién le pertenece eso?

M - A mi habilidad de expresión en el instrumento.

Bueno, al compositor ya lo tengo asumido, ya lo ví, lo analicé. Luego lo mío y después viene lo del público como me responde con el Feedback.

I - O sea que a todos.

$\mathrm{M}-\mathrm{A}$ todos.

(2)

I - ¿Qué sería lo que se comunica? ¿Existe algo para comunicar?

M - Ya te digo, esto de la emoción para mí. El afecto. Bueno también estás diciendo como una frase, estás diciendo un motivo.

I - ¿Y a quién le pertenece eso?

M - Eso de todos. De cómo la recibe, quién la recibe, del que toca y del que la escribió.

(3)

I - ¿Hay algo que se pueda comunicar?

M - Que se yo, alguna emoción, seguro. Algo desde lo emocional. Si no te pasa a vos, dudo que lo puedas comunicar. Si querés que la gente llore tenés que estar casi por llorar vos. Sino, dudo que eso suceda. 
La gente, yo creo, si va a ver así un espectáculo de música de tipo cámara está esperando algún tipo de pero sino se duerme, se aburre, no le gusta. A mi me pasa a veces con cosas que no me transmiten nada y me parece que fui de gusto.

I - ¿Pero si te transmitiera es tuyo o del que está tocando?

M - En el momento que uno la transmite sí, es del público también.

(4)

I - ¿Existe algo para comunicar?

M - Hay una música que se está tocando en particular. No estás tocando cualquier cosa, pero luego tampoco la estás tocando a cualquiera. Más que nada tiene que ver con esto que te decía que si uno logra que las cosas se hagan, que recuperen naturalidad, que se hagan vivas, lo que transmitís es eso. Es la obra hecha vida, eso es lo que tiene el hacerlo en vivo, que no tiene cuando no está el intérprete ahí en el escenario.

I - ¿A quién pertences eso?

M - A una persona no. O a algo puntual no. Ese sí es el evento, que no es el acontecimiento, es el evento, es eventual. Es el que está sentado, son los que están sentados arriba, abajo del escenario. Es todo, por supuesto la música obviamente.

(5)

I - ¿Existe algo para comunicar?

M - Sí, el gesto corporal es fundamental. Fundamental. Y que depende de vos como intérprete, ¿no? Vos vas a anunciar que vas a empezar a tocar. Anunciás que el otro deje de hacer...

I - ¿Y cuando estás tocando?

M - También, al tocar sí. Porque tu brazo es como si fuera... No sé, tal vez es exagerado, pero el brazo del pianista es la envolvente de ese sonido, ¿si? Entonces lo mira y lo escucha. Es fundamental el gesto todo el tiempo de sostén.

I - Y eso que se comunica, ¿a quién le pertenece?

M - A todos. Sí. Es el momento, el que toca, el compositor, el que escucha.

En la performance...

(1)

I - ¿Qué está haciendo el público en ese momento?

M - Una fracción de su tiempo lo dedican a escuchar lo que estoy haciendo. $Y$ eso es muchísimo. Ya eso para mí es digno de agradecer. Que escuchen algo que vos tenés algo para decir... Y qué es lo que estás diciendo en lo que estás tocando. Cómo se transmite esa obra que el compositor creó a partir de tu ejecución, de tu interpretación. Es muy importante eso.

(2)

I - ¿Cómo es la situación de estar tocando en público? ¿Qué cosas creés que hacés vos y qué cosas hacen los demás?

M - El concierto es como una experiencia personal de maduración de una obra. Cuando vos tocás en público la obra... ya tenés una impronta distinta, se va madurando y cuanto más la toques, mejor digamos, ¿no? O sea, esto es un nivel. Y una realidad que tenemos que hacer obviamente y está muy bien.

Yo lo que intento ahí es qué puede dejar uno ahí. Qué energía uno puede dejar ahí, que mensaje uno puede dejar ahí. Y no mensaje en el término emisor-receptor, eh. Sino qué cosa de esa vibración que sucede en una obra musical. En cada gesto, en cada tránsito del brazo sobre el teclado pasan cosas que llegan a la gente, en algún punto lo perciben. Trato -trato, porque no está todavía absolutamente incorporado eso, son búsquedas realmente- que lo que uno está expresando ahí tenga que ver como un 
"decir" de lo que vos interpretás... la locura, la serenidad, la placidez, lo expresivo. Todo eso, que uno encuentra en una obra.

(3)

M - A mi nunca me gustó estar super-atado a un esquema de interpretación. A mi siempre me pareció más importante que haya una cuestión discursiva, de expresión. La capacidad de adaptarse al momento, de lo que uno está necesitando. Y uno sabe que "según como toqué esto, después esto lo voy a tocar distinto", y después...

No es que no tenga una manera de tocar. Seguramente yo agarro una obra, la estudio y va a tender a sonar parecida pero lo que siempre evité es trabarla, "acá tengo que llegar con este forte, con este piano". Me parece que es más importante siempre que haya cierta flexibilidad que es lo que permite que uno escuche con cierta naturalidad el discurso y tenga una cosa como más fresca.

Yo creo que parte de eso que he conservado tiene que ver con ese aprendizaje intuitivo de escuchar música, de gente como Eduardo Falú, que tenía una concepción desde la energía desde transmitir algo.. Lo que me quedaba de Eduardo Falú es que vos escuchás y decís... algo te llega. (pausa) Pero vos escuchás algo en el toque, en la expresividad... que yo creo que algo te llega.

(...)

Eso del esquema es algo que yo puedo notar. Escucho versiones que no son contínuas, con una expresividad que no.... Uno no escucha como una continuidad en la expresión, por ahí pasan algunas notas... es obviamente subjetivo.

(4)

I - ¿Pensás que tiene que ver con lo que hace el intérprete cuando toca una obra más de una vez?

M - Pienso que ningún momento es igual a otro. Esto es como lo humano y normal. Hay un elemento creativo, de la imaginación creadora de la persona que bueno, no sé, algunos están más acostumbrados a reproducir y otros a inventar. Pero siempre en esa reproducción hay algo que tiene que cambiar.

I - ¿Por qué pensás que tenemos la necesidad de eso? De no volver a repetir

M - A mi en lo personal me asfixia esa cosa, me encierra. Algo creativo pero que además es incierto, es indeterminado. O sea, algo que vos no sabés y que pasó, y como pasó te sirve para cambiar otras cosas. Me parece que es lo más fascinante, es lo incierto que pasa. Esa capacidad de asombro tal vez, que nos da eso.

(5)

I - ¿Te pasó que te haya pasado algo fantástico que nunca trabajando en la obra lo habías logrado?

M - Sí, supongo que sí. Es más fácil ver lo que no te sale (ríe). Digamos, uno siempre sale más insatisfecho que satisfecho. Uno va siempre cargado de aspiraciones, como que es más una situación de evaluación por eso uno ve más lo que no te sale.

Pero sí, también salen cosas que uno no imaginaba porque... a ver, eso me ha pasado más, no cuando uno toca una pieza, sino cuando hace un concierto entero. Porque un concierto entero hay que transitarlo y ahí también juegan otras cosas que tienen que ver con el tiempo. Uno no es el mismo cuando empezó el concierto, cuando uno sale a escena y saluda que cuando te cansaste ya de tanto nervio. Entonces hay algún momento en el que uno suelta las riendas del control, por cansancio, sin querer. Ahí se te puede ir todo al cuerno o no, al revés, de pronto empezar a aflorar cosas muy positivas. Ahí es un tire y afloje también de riendas que hay que tener pero es difícil transitar lo largo que es el concierto, sí. 
(6)

M - Pero a mi en particular me pasa que tengo identificados estados emocionales, y son infinitos porque cada pasaje, cada obra, son todos diferentes. No son categorizables: "esto es triste", es ridículo... no se ni ponerle nombres. A veces tienen que ver con estados inclusive...

I - ¿En el momento de tocar hay otras personas, aparecen esas cosas?

M - Seguramente está todo, no estoy pensando en alguna cosa puntual. Ahí ya estoy concentrada en acordarme de todo lo que, cosas que fueron apareciendo mientras trabajaba, pero ya están todas combinadas. Pensado es en el trabajo, y un día en una dirección, otro día en otra.

(7)

M - Siempre me he esforzado en que el repertorio que toque sea un repertorio con el que yo tenga cierto feeling (ríe), así que me guste, que yo sienta que tenga, que vale la pena...

Porque también está el concepto interesante, del disfrute de tocar, en el momento de tocar, que uno tiene que tratar de que el que te escuche disfrute. Si lo tocás de compromiso es difícil que a vos te termine gustando y que a la gente que te escucha le termine enganchando. Trato de buscar siempre un repertorio que tenga un valor, para mí. Y me gusta también un poco eso, a veces, de pensar quién me va escuchar también. Entonces, justamente como yo quiero que la gente disfrute, entonces bueno voy a tocar...

(...)

Yo creo que uno con la obra, vos querés como... es el tema de expresión, bueno estás diciendo "bueno, yo hice esto". Yo creo que eso es lo primero, estás comunicando algo, sin duda. Estás diciendo "yo..." estás mostrando una visión, una cosa que tenés dentro la estás plasmando en algo y le estás dando forma a la obra.

(8)

M - Lo que no me gusta es el afán de la perfectibilidad. Que sea perfecta la obra. Entonces siempre estás cargoseándola, modificándole... entonces pierde espontaneidad por ahí. $Y$ con algunas obras, quizás las mejores, quizás me pase eso. Querer que sean perfectas.

I - ¿Y lo lograste?

M - En algunos casos sí. Un gran placer, sentirme contento.

I - Si tuvieras que tocar una misma obra en cinco conciertos, y la primera vez te sale perfecta. Pero la vas a tener que volver a tocar en algún momento...

M - Si, si. Más cuando salís de gira. Yo, las primeras giras que empecé -a parte de la radio y eso, donde tenés la intuición del público pero no lo tenés ahí, tenés algunas personas pero las contás con los dedos de la mano.

Pero, hablando del público, salís y tenés un programa -cambiado, pero algunas obras repetidas-. Y no, las vas a tocar diferente, te equivocarás.. O no, al fin y al cabo no sé. Es como salir a jugar al basquet, o al fútbol y llevarte la pelota, sos el gordito y te llevás la pelota; que no haya excusa, vos vas a salir y vas a patear, no te vas a quedar con las ganas, porque uno lo hace por placer el hecho de salir a tocar. No de ser mejor, de vender mucho, o que haya mucha gente, poca gente, sino porque le gusta hacer eso, es lo suyo, es como respirar. Vos me dirás "es muy ideal esto", pero es así, yo no te puedo mentir.

Entonces tenés que repetir, y bueno, la tocarás diferente. Gustará más en un lugar, gustará más en otro, preferirías no tocarla cuando estás en otro, porque es muy larga y se te va el tren (ríe). Hay pueblitos de la provincia de Buenos Aires, ciudades donde yo los conozco muy bien de nombre pero si me largás de día no te los puedo diferenciar, iporque se me iba el tren! Tenés que viajar y volver en el día o al otro día. Entonces ahí acortás una obra (ríe) porque se te va el avión o se te va el tren, no la cambiás por otro 
motivo, "che, éste público no está tan formado como el otro". No, nunca juzgás al público, porque tenés las grandes sorpresas, eh. No hay públicos analfabetos en música. Todos los públicos tienen sensibilidad. Y por ahí los más intelectuales, los más trajeados, los más corbateados y los más moñudos son públicos fáciles para aplaudir, o para retener el aplauso, pero no son los más "comunicantes", digamos. Es así.

Y te encontrás con públicos amorosos, que están esperando recibir, que no hay casi reacción, vos terminás y hay asombro, tardan en aplaudir, nadie se apura para ser el primero, para ostentar que conoce la partitura.

(9)

I - ¿Qué te pasa cuando alguien te dice eso? ¿sentís que es válido? ¿o a vos también te había pasado? ¿vos pusiste eso?

M - Yo creo que pasa, esa conexión, esto que te decía, que si uno disfruta, el otro disfruta. Era una obra que me gustaba, porque sabía que llegaba, a mi me gustaba tocarla. Y yo sabía que... que cerraba. $Y$ de repente pasaba eso, que te decian... porque uno justamente se conmueve tocando también, es la única manera. Si vos conseguiste que el otro... es como esa cuestión de conexión que pasa porque vos estás conectado con la obra, y buscás retenés, y... no lo hacés para que el otro llore, lo hacés vos porque estás ahí comprometido con la obra en el momento... A mi me ha pasado estar tocando y sentir piel de gallina en la espalda.. Es algo, por ahí otro tipo de cosas, más emocionantes, estás así "fffff...", y es otro tipo de emoción.

I - ¿Y te pasa ahí o te había pasado ensayandola, o de ese momento que te sorprendió?

M - Creo que... siempre en el momento te sorprende, cuando se produce.

I - O sea que no tenías ni conciencia que lo estabas generando en vos.

M - Claro, claro, es algo que pasa que vos de alguna manera en el momento lo sentís como "que bueno", porque lo sentís como algo fuerte, sea hacia llanto, piel de gallina, o una cuestión de agitación, en el momento te sorprende. Porque vos no estás buscando conscientemente eso, pero es algo que está en la obra como latente... yo creo que sí, que son virtudes de las obras, ahí si, que permiten que uno en determinado momento... permite que uno se vaya adaptando en el momento, en el 'en vivo' a esa expresividad justamente a lo que te está pidiendo la obra, te pide un poquito más, te pide un poquito más, te viene la sensación de que lo tenés que hacer de esa manera, lo hacés y lo escuchás y ah... (suspira) y es buenísimo (tono de felicidad). Sí, en el momento te sorprende. Es difícil que se repita exactamente... después es inevitable la tentación de... la volvés a tocar otra vez, otro día... volver a generar lo mismo.... Y, ya no. No va a ser... es difícil que se repita... por ahí en otro lugar, o por ahí.... Pero exactamente la misma sensación... Pero es dificil cuando uno repite mucho, cuando uno estudia, porque hay cosas que se empiezan a desgastar.

Me ha pasado también, de tocar creo que me ha gustado más esto de compartir, está bien decir compartir, la música de uno ante gente 'no erudita'.

Me ha pasado tocar con gente que no conoce de música, la gran obertura y cuando así una catarata de notas con energía, y escuchar "haaaaaa" así, el público cerquita, unos muchachos que flashearon, y a mi me encanta (ríe)

\section{El performer}

Los fragmentos de la entrevista referidos al performer implican un aporte personal en la performance de una obra, su definición de acuerdo a lo que hace, cómo se siente, qué rol ocupa, y su experiencia en general. 


\section{El aporte personal}

(1)

I - Entonces ¿qué pensás vos que aportás cuando interpretás una música?

M - Que la gente entienda lo que yo le quiero dar. Que se de cuenta.

I - ¿Y qué sería eso que vos querés dar?

M - Lo que yo me propuse. Por ejemplo quiero que en este momento, que sea crucial, que la gente se quede impactada, que sea una cosa nueva, que no sea predecible. Y si veo que la gente lo percibe, me pongo re contenta. Eso le aporto. Que haga eso, que le pase eso.

(2)

I - ¿Y qué pensás que es lo que vos le aportás con tu interpretación a la obra?

M - Yo siempre pienso en el cariño, en la ternura, la cuestión del afecto, ¿viste? Esa cosa ... siento eso, no sé, como que es lo más fuerte. Como que el afecto, los afectos, la emoción siento que es lo que puedo aportar. Ahora, en otro plano no sé.

I - Está bien, es lo que a vos te permite decír: soy yo.

M - (Asiente con la cabeza).

(3)

I - ¿Qué te parece que vos como intérprete tenés para aportarle a una obra?

M - Carácter, supongo. De hecho no me gusta tocar cosas que sean muy livianitas, o muy clasiconas. Paso. Me gusta como ponerle ovario a la cosa.

I - Desarrollame un poquito más.

M - ¿La impronta? Como sonido, a mi me gusta (algunos me lo han dicho) si escuchás decís "Ah, ahí está tocando ella". Como que, no sé, de alguna manera Soy Yo. Y yo hablo a través del piano. Ser más auténtico con lo que uno hace. No importa que esté bien o mal o mejor o peor. Ser fiel a lo que uno le parece que tiene que sonar. Nada más.

(4)

I - ¿Qué le aportás vos con tu interpretación a una obra?

M - No se si yo, creo que cualquiera. Vida. En el papel la obra, no... Yo no sé, lo tendrían que decir los demás.

Yo sé cuando escucho a otro las cosas que él no vio y que yo ví. También lo opuesto. Se sentir la diferencia de lo que yo... Con otro como yo, equiparable a mí.

(5)

I - ¿Y qué le aportás vos a la obra con tu interpretación?

M - Yo creo que a la obra le aporto algo que es... una concentración tímbrica importante, yo creo que pongo mucho énfasis en la construcción sonora de esa obra. Yo creo que somos como el obrero de la construcción sonora de esa obra, que hay una nota escrita y todo... pero esa relación, y como es esa envolvente en el piano que es tan interesante, y como el pedal va a sostener ese sonido hasta enganchar el otro, para mi eso es... (pausa) $Y$ es una conexión a veces un poco autista que uno tiene con el sonido, ¿no? Se tiene que conectar con el público porque sino es como que es la obra y uno y el sonido que se genera, ¿no? Una envolvente diría sonora, ¿no?

El aporte es eso, el cuidado sonoro, la búsqueda constante del sonido.

I - Cuando me decís "el obrero" no es porque sea lo más bajo de...

M - No, todo lo contrario. El constructor de eso, sí, sí.

(6)

I - Entonces ¿qué pensás vos que aportás cuando interpretás una música?

M - Lo que básicamente aporto es una cuestión emotiva muy personal. 
(7)

I - ¿Qué pensás que aportás con tu interpretación?

M - Yo pienso que es un poco la entrega, que vos tenés, siempre está la cuestión afectiva me parece, esta cosa que vos querés. Vos querés entregar algo cuando tocás.

Yo siento que es el afecto, algo que uno le salga lo bueno digamos. La bondad o el bien son esas cosas que a mi me interesan, pero después también el cariño o la ternura o la cosa así agresiva que vos decís bueno "acá estoy" o "tomo decisiones". La personalidad, éstas cosas de...

(8)

I - ¿Y qué te parece que le aportás vos?

M - Yo aporto parte de mis vivencias internas y también mucho estudiando la parte técnica. Porque si vos no tenés la parte técnica, tiene que ser tocada sin ninguna duda interna tuya. Entonces después transmitís.

Yo aporto desde mi manera de tocar, porque me lo han dicho a eso. Yo le pongo algo mío siempre.

(9)

I - ¿Qué te parece que le aportás vos a la obra? ¿cuál es tu aporte?

M - Básicamente, lo que le aporta cada artista a la sociedad, que es el punto de vista personal. Y yo, en lo personal, estoy convencido, que estoy aportando algo sincero, vamos a decir honesto artísticamente, desde mi concepto de "libertad" que siento que es obligado -porque sino no vale la pena hacerlo- porque si vos no estás aportando tu subjetividad... medio que no sirve. Creo que el rol del intérprete es... salvo que haya un objetivo externo que sea mostrar el repertorio de determinado compositor, y bueno ahí el objetivo es el compositor. Pero bueno si yo soy intérprete en ese momento voy a estar aportando ese punto de vista que creo que es de lo que se nutre... y es un montón. A la vez siento justamente que esto de la cultura y del arte, y que siempre se dice que es importante, y bueno, es importante porque hace bien, el intercambio. Porque es una cosa que creo que como sociedad retroalimenta, ¿no? Esto de que escuchas a alguien y decís "uh, que bueno esto" y llegás a tu casa y tenés ganas de tocar la guitarra, vos como viste a alguien... Me han dicho un elogio, aunque haya sido mentira "sos el único guitarrista que me hace llorar". Yo lo tomé porque me parece bien, llegar, porque si se llega a algo así, está bueno.

\section{¿Quién el performer? Cómo se define}

(1)

I - Quiero que me definas lo que hacés cuando interpretás una obra.

$\mathrm{M}$ - Soy un medio para llevar a que alguien lo escuche.

I - Entonces ¿qué habría en ese medio?

M - Interpretar lo mejor para que se llegue. Lo importante es qué le aportás con tu música.

I - ¿Y qué otra cosa podrías ser? Por ejemplo, otra profesión.

$\mathrm{M}$ - Un actor, un escritor, un cineasta. Y, un actor también es parecido.

I - ¿Y un escritor por qué?

M - Le estás provocando al lector una cosa que vos sacaste de vos mismo, la inventaste. Le hacés llegar, le promovés, le provocás algo al lector.

I - O sea que ¿para vos interpretar es como inventar?

$\mathrm{M}$ - Inventar o re-crear.

I - Re-crear es volver a crear.

M - Sí, sí, sí. 
(2)

I - ¿Te sentís otra persona otra persona cuando estás tocando?

M - No creo. No se, no. Justamente trato de ser lo más auténtica que puedo. Ser yo. Sí, busco eso. En realidad busco ser como lo más honesta que puedo conmigo misma. Soy esto. Trato de comunicar, o un objetivo claro que tengo o para ejemplificar algo, y trato de hacer música. Desde ese lugar, de hacer música y que puede inferir. Aunque sea sencilla, trato como de interpretar eso, ponerme a tocar eso yo, como lo siento yo.

(3)

I - ¿Y cómo te ubicás con respecto a la música?

M- Para mí, la música es como una profesión. Es como que hay mucha gente que tiene muy mistificado todo eso de dedicarse a la música, como una cosa así especial. Para mí es una elección de lo que uno quiere hacer. O lo que se me ocurrió hacer, que se yo, nunca me propuse hacer otra cosa. Pero es como algo que uno hace. Así como el abogado redacta expedientes, nosotros tocamos un instrumento y ofrecemos eso al mundo, que se yo. Es una profesión, no es ni un estilo de vida, ni una filosofía, ni un estandarte, ni nada.

I - ¿Pero vos pensás que existe algo que es la música?

M - La música es algo que se hace, algo que nos implica a todos, desde que nacemos, algo que está en el aire, no sé. Y yo elijo reproducir algunas cosas, y otro elegirá reproducir otras cosas. Pero no me gusta endiosar, no es así.

(4)

I - ¿Te sentís otra cuando estás tocando?

M - No, de hecho me siento más yo que nunca.Porque ya te digo, es como que si hablara a través del piano. Como que la versión más genuina mía es a través de lo que estoy tocando.

I - ¿Pensás que existe una comunicación entre vos y los demás?

M - Sí, porque uno en la manera de afrontar el sonido está diciendo algo. Si.

(5)

I - ¿Te sentís otra persona cuando estás tocando?

$\mathrm{M}$ - No, soy yo.

(6)

I - ¿Y te parece que podés llegar a ser otra cuando estás tocando?

M - Sí... otra persona sí.... Yo me conecto con otra realidad. Mucho mejor, aparte. Eso seguro. Para mí... yo me transformo: otro mundo, otro espacio, otro lugar.

Me cuesta volver a veces, eh. En esa sensación, ¿no? Por eso bueno, cuando bajo los brazos y bajo las manos es ahí cuando... Yo te digo que sí, es una situación ceremonial de cierta magia porque es... es metafórico completamente. Una situación, sí... te transporta a un mundo fantástico.

(6)

I - ¿Y seguís siendo el mismo?

M - Si, estoy como en estados distintos, ¿viste? Cuando estoy tocando puede ser parecido, como si fueren varios yo... Cuando era chico tocaba mucho para que me vieran. Ahora toco para que me escuchen. Que me escuchen pero que disfruten, no que me presten atención nada más.

Esto es así: lo que me interesa es la obra. Entonces yo disfruto la obra y el tipo disfruta la obra. Como consecuencia, si lo disfrutó le gusta lo que estoy haciendo. Pero básicamente es la obra lo que me interesa. 
(7)

I - ¿Te sentís otra?

M - Sí. Y uno se siente así como... cuando estoy ahí el espíritu se libera y va para arriba, y se amplía.

I - ¿Quizás uno se pone de otra manera?

M - Sí, más me pasa cuando he terminado el concierto. Antes, volvía del concierto y lo tocaba todo de nuevo en mi casa (ríe). Me acordaba del concierto, todo. Era una necesidad que tenía.

I - ¿Y sentís que estás en otro lado?

M - Determinadas músicas sí. Como si fuera en otra dimensión. Pero después vuelvo en seguida, porque tampoco quiero estar demasiado en otro lado (ríe) porque la vida real es la vida real. Pero yo me tomo mis momentos.

(8)

I - ¿Te sentís otro cuando tocás?

M - Hay como un cambio de rol. Hay una sensación distinta.

I - ¿Y cómo sería?

M - Es como que de repente decís “upa, que hago acá?” ¿no? a veces me pasa. El tocar en público tiene así como una cosa así vertiginosa, así, hay como una cosa como de adrenalina que no se... uno dice que está bueno, pero antes te da miedo. Yo soy de esos que en el momento lo disfruto, después lo disfruto, pero los cinco minutos antes estoy tenso, ¿no?

Aparte estás como en una vidriera, pasás de estar de espectador... Y que cada cosa que hacés tiene... esa es una sensación, sí, sí, muy de tocar en público. Estas tocando e inconscientemente esta sensación de que sos el que está produciendo los sonidos ¿no? en el momento. O sea que si vos dejás de tocar... es como esa cosa que a veces dicen del que están en el borde del precipicio y que dicen "uh, yo acá si me tiro..." ¿no? Estás tocando y decís "si me equivoco, si dejo, de tocar, si me olvido, si..." ¿no? hay como una sensación así, como que sos el responsable de ese momento, esa cuestión de esa responsabilidad que tenés en ese momento.

Por ejemplo, tocar la gran obertura, que es una obra que es virtuosística, que es difícil, que a mi me ha gustado tocarla pero siempre estoy sudando la gota hasta el último instante que la estoy estudiando, y cuando la estoy tocando también. Y también por esa cuestión de que vos sabés que la tocás... igual con respeto siempre, no es que uno va a subestimar, pero yo digo "está bueno que esta obra suene, y que la pueda escuchar determinada persona, aún con mis errores, con las cosas que no suenen perfectas. Porque finalmente no es lo más importante, aún en una obra, dentro de un concepto de perfección, sino dentro de estas cuestiones de expresión y todo. Y que uno a veces con el repertorio estás mostrando el punto de vista, tu punto de vista.

Pero bueno, en el momento no deja de tener esa cuestión así como vertiginosa, o sea, lo que es en público, aún tocando bien y sintiendo que....

Lo que tiene el tocar en público, especialmente, es que requiere una actitud mental de ponerle garra. Si te aflojás... mal, en el sentido de abandonarte, ¿no? Abandonar el momento.

Tocando en público hay distintos momentos. Hay momentos en donde estás luchando por concentrarte, momentos que son los mejores que es cuando cuando estás consiguiendo la expresión, estás soltandote y de repente fluye, y estás como disfrutándolo a pleno. Creo que es como la mayoria, porque hay un disfrute en escuchar que suena bien. 
(1)

I - ¿Cómo te sentís cuando estás tocando, interpretando?

M - En otro mundo. Porque sale la música de mis manos así solita, como magia.

I - ¿Estás pensando en alguien cuando estás tocando o solamente pensás que estás vos?

$\mathrm{M}$ - No, no pienso en nada, pienso en lo que estoy tocando.

I - ¿Y vos estás?

M - Ahí. Sí, hay que estar alerta, sino no.

I - O sea que estás ahí. ¿En dónde?

M - En mi cabeza, en mi físico. Mente y cuerpo.

I - Y con respecto a la música. Si la música pudiera ser algo, por ejemplo, un cuerpo físico ¿cómo te sentís? Que estás con la música, que estás en la música, que estás al lado de la música...

M - En... En la mùsica

I - ¿Pensás que cuando estás tocando música seguís siendo la misma?

M - No. Estoy expresando algo, y a veces no estoy expresando nada. Estoy en un bar charlando con cualquiera. Expresás cosas así muy nimias. En cambio de otra forma estás expresando algo tuyo que sale, como vos lo podés mandar. En la música.

I - Es como más fuerte.

M - Sí.

I - ¿Pensás que hay más gente también en esa música?

M - Quizás a veces, puede ser alguien que te está escuchando, alguien que te está viendo. Puede ser imaginando, puede ser que se te cruce alguien.

(2)

I - ¿Y vos dónde estás cuando estás tocando?

M - En realidad trato de no ser el centro. Porque si yo me siento como que soy yo el centro ahí muero porque me empiezo a cuestionar todo. Que esto no está bien, que esto que lo otro.

I - ¿Cuando estás tocando te pasa?

M - Sí.

I - Entonces si no sos vos ¿qué otras cosas más habría?

M - No. Soy yo en ese aspecto, de que me critico.

I - ¿Qué sería el centro?

M - No sé. ¿Sabés qué es lo que a mí más me atrapa? El sonido, eso es lo que más me parece que trato de estar ahí, en ese sonido que se produce o cómo resuena, si está sonando adentro del instrumento. Esas cosas me atrapan mucho.

I - Entonces sería estar en el sonido.

M - Sí.

I - ¿Cómo es la sensación física de estar en el sonido?

M - Estar escuchando sería. No sé, yo estoy disfrutando de cuánto duró ese sonido, la resonancia que tuvo, si aparece de un lado o del otro.

Ese es el placer al que yo me refiero. Esas cosas te van sosteniendo en el estudio de la música, del instrumento y de la música también.

(3)

M - El piano siempre te tapa, un poco. Se te ve el perfil, digamos. Pero cuando estás dirigiendo no, se te ve todo, todo el cuerpo porque ponés el cuerpo.

$\mathrm{I}-$ ¿Y vos en el piano qué sentís, como que estás adentro del piano?

M - No, no, como que estás acompañada. No estás haciendo un monólogo parada y se te ve todo el cuerpo. Estás sentada ahí, y el piano, es como que somos un equipo. Como que no soy yo sola, el piano también participa.

I - ¿Y vos dónde estás? 
M - En el control absoluto. En la cabina de control estoy.

I - ¿Y cómo se siente eso? ¿Cómo lo sentís?

$\mathrm{M}-\mathrm{Y}$, a veces medo agobiante. Como que tenés que controlar mucho de la situación. No sé, ya te digo, es como una guerra interna todo el tiempo, de tratar de no autoboicotearte demasiado "esto salió mal", "esto tendría que haberlo estudiado más". Esto, esto, esto... No. Es como que tenés que decir "ya está", "ya estamos acá" "disfrutemoslo".

I - ¿Te hablás a vos misma?

M - Sí. Mal. Todo el tiempo. Creo que es el momento en que uno más tiene auto-diálogo. Porque siento que si yo me escuchara a mi misma en ese momento estaría pensando eso. "Esto $\mathrm{mmm}$, acá faltó, y esa digitación... mmm." Todos detalles. Todos detalles que no hacen a la música y no se escuchan además. Porque vos te ves a los años, o al otro día, o a los dos días, ves el video, escuchás la grabación y todo eso que apareció en tu cabeza no se escuchó. Son dos cosas diferentes. Pero al momento de hacerlo es un duelo. Un duelo entre cerebro, corazón, oreja.

I - Entonces no es solamente el control, aparte tenés información de lo que te va pasando corporalmente.

M - Sí, ni hablar.

(4)

I - ¿Por qué uno busca hacer música, agarrar una obra nueva?

M - No sé, eso. Es un disfrute enorme. Me aburro si no lo hago, lo necesito y en especial lo necesito físicamente. Uno nunca se siente igual en el transcurso del estudio una obra. Hay días que uno está indignado, que no te sale nada, a veces te dura meses hasta que le encontrás la vuelta. Uno no se siente siempre bien. Hay días que uno amanece y sale todo increíblemente ¿por qué no se repite?

(5)

I - ¿Cómo te sentís cuando estás tocando?

M - Cada vez que toco como que es muy diferente. Todas son sensaciones diferentes. Una vez casi me duermo, tocando, del aburrimiento, que era. Otros momentos era como increíble, una sensación de que estoy volando, otra alegría total.

El hacer música tiene muchas diferentes maneras de ser y esas son también muchas diferentes maneras de sentir.

(6)

I - ¿Y vos dónde estás?

M - En otro lado. Me voy.

I - ¿Y la música?

M - Y la música es algo que está ahí, no sé. Yo estoy con la música y la música se fue conmigo. (ríe) No sé como explicarlo.

(7)

I - ¿Cómo te sentís en el momento que estás tocando?

M - En el momento bien. Antes siempre me dieron ganas de decir "para qué me metí en esto"..

I - ¿Antes antes de tocar?

M - No, antes antes no. Unos días antes. Ese día no. Ese día pongo toda la energía en decir "bueno, toco, tengo que tocar, me hago un espacio, me voy a otro lado, cambio". Me pasó que había estado trabajando acá. Entonces volví a mi casa me cambié, una pavada, el peinado, entonces cuando volví a entrar, entré en otro rol. Entré para tocar la obra. Y hay un poco de puesta en escena, y yo creo que eso te ayuda. A mí, a otro le ayudará otra cosa.

I - ¿Pero cómo te sentís vos? ¿algo más personal? 
$\mathrm{M}$ - $Y$, yo siento adrenalina y esa adrenalina se tiene que transformar en un gesto completamente musical. Ahí es la acción, la adrenalina puesta en ese gesto musical, en el momento de la concentración y empezar a tocar. Es un momento mágico, eso sí es un momento mágico. Te sentás, te concentrás, obligás a un silencio, que no vas a empezar a tocar hasta que no haya un auditorio que escuche. Y ahí empezás. Y en el gesto corporal es muy importante, muy importante. Das cuenta que esto empieza. Vos, tu ejecución antes.

Me parece que la performance de concierto es una performance que está cambiando, por suerte, pero que supone una puesta en escena, una acción teatral, ¿ ¿í? Aún así en lo tradicional de sentarte al piano. Es una acción teatral. Es la conexión con el público, el silencio, la escucha y el sonido que va para un lado y va para el otro, una puerta que deja de abrirse, y aparece una imagen, ¿no? La luz...

I - ¿Qué diferencia hay entre esa adrenalina y la vida cotidiana?

M - Vos estás haciendo algo y podés dispersar tu cabeza. En la acción de tocar, en la adrenalina, estás generando un hecho artístico, es completamente distinto a manejar, a... (pausa) Es generar un hecho artístico. Y lo metafórico, y qué es lo que estás diciendo, y le das... No tiene una utilidad, no tiene una... una utilidad específica como otras actividades que te pueden poner en riesgo. Es otra cosa.

Acá hay... Yo te diría que hasta un momento, no me sale la palabra... no quisiera decir mágico, pero hay un poco de eso, de lo metafórico, ¿no? Es un momento que se construye a través de... puede ser un elemento que sea real pero se transforma en otra cosa. Me parece que es así, muy distinto a otra actividad... generás un mundo paralelo, ¿viste?

I - ¿Dónde estás en ese momento?

M - En otro mundo. Y vuelvo, voy y vengo, eh. Es una cosa... Sí, sí, sí, sí. Yo en lo particular tengo que hacer esfuerzo para no generar ésta envolvente sonora que hasta digamos que es un poquito autista, ¿no? Por eso me gusta mucho la música impresionista, tocar ese tipo de música en la cual lo sonoro es envolvente completamente, ¿no?

(8)

I - ¿Cómo te sentís cuando estás tocando, interpretando?

M - Y bueno, vos no vivís en un estado de emoción estética. Entonces, cuando vos estás ahí tocando estás en otra.... Estás sintonizando otra cosa, una hondura, una profundidad distinta. Yo la consigo cuando estoy tocando. No puedo decirte que es una gran alegría, ni una gran tristeza, es un estado diferente. Y que se mueve con respecto a la música que está... que está ocurriendo y.. Cuando logro integrar todo el cuerpo... no es misterioso porque algo me sucede.... Es algo muy hondo.

I - ¿Y tenés alguna idea de cómo te das cuenta?

M- Por cómo siento el cuerpo. Es como experimentar una satisfacción muy grande porque es como que estás manejando algo que es totalmente emotivo... pero son sonidos y son sonidos con emoción...

I - Y pensando que uno lo vuelve a tocar, ¿se vuelve a repetir lo mismo?

M - No hay una intencionalidad a priori de decir "hoy voy a ir a buscar tal cosa". Yo no sé si me pasan cosas distintas, pero no suena siempre igual. Un día se destacó más una cosa, y otro día es otra cosa. En ese sentido hay una predisposición no-consciente. Algo a cierto nivel que yo no lo hago consciente pero que está.

I - ¿Y vos dónde estás?

M - En la música. Hay un paisaje sonoro y hay un paisaje sonoro, y no hay más.

I - ¿y vos dentro de ese paisaje qué estás haciendo?

M - Tocandolo (ríe). Claro, moldeándolo, modificándolo. 
(9)

I - ¿Cómo te sentís cuando estás tocando?

M - Cuando estoy tocando tengo que aislarme de todo, o sea, depende de lo que estoy haciendo.

Me siento.. Estoy eligiendo obras que me hacen feliz.

Si logro lo que quiero, si salen las cosas bien, me siento muy bien, y no necesito más.

También toco músicas que me evocan paisajes. Porque yo cuando estoy tocando veo cosas, veo imágenes. Cuando estaba tocando Debussy veía un jardín con la lluvia y todo eso. Yo tocaba y estaba mirando al mismo tiempo. Eso es una imagen que surge, del cerebro. Si no toco no aparece, la música es lo que influye. Si yo me integro a la música, entonces el que me está escuchando también se integra.

I - ¿Y usted dónde está?

M - En la quinta dimensión.

(10)

I - ¿Cómo te sentís cuando estás tocando?

M - Serían adjetivos. Y leyendo siempre me encontré con adjetivos y me repulsan los adjetivos. Eso de "estar en la gloria", "me sentía transportado maestro, por su música", a ver ¿qué quiere decir transportado? (ríe). No hay términos, yo no los encontré. Como se siente uno. Yo sé que me siento en lo mío. No es nada importante, es como se debe sentir un jugador de fútbol jugando. Un corredor de automovilismo.

Cuando tengo necesidad de tocar es irrefrenable, voy y toco. Con la música tenés que cumplir, es una necesidad. (ríe).

(...)

Cuando me encuentro con alguien en algún teatro me dicen "¿tocás la guitarra?” y yo les digo: “¿Y, cómo querés que haga para no tocarla?". Es al revés: “¿cómo querés que haga 'sin'?"

I - ¿Te sentís otro?

M - Sí. Y ahí volvemos a los adjetivos. ¿qué te digo? Mejor, peor, más pleno... ¿qué te puedo decir?

(11)

I - ¿Cómo te sentís cuando estás tocando?

M - En principio creo que hay una variedad importante de cómo te sentís cuando estás tocando en público, o cuando estás grabando.

(...)

En vivo te diría así como un goce, un disfrute, básicamente eso. Hay una cuestión a veces con una cuestión vibracional, no? Está la cuestión expresiva que suele surgir así en el momento de tocar en público, lo que es el tema de la obra y la expresión de la obra. Pero a veces me pasa que estoy haciendo técnica en mi casa.. Y toco los graves y me gusta, que se yo. $Y$ es como que me produce placer esas notas, y no estoy haciendo música. A veces en la música se apela a las cuestiones físicas.

Así como pasa con las artes plásticas que hay un goce así visual bueno con la música es algo distinto que es el cuerpo. Y con la guitarra así también, te vibra y es así el goce de un sonido bello, que es subjetivo.

\section{El tiempo}

Los músicos se refirieron a la relación entre la música y el tiempo, el tratamiento del tiempo en su interpretación de la obra y la pertenencia de ese tiempo. 
(1)

I - ¿Cómo te parece que la música se vincula con el tiempo?

$\mathrm{M}$ - ¿en el momento en que está sonando o en general?

I - Qué hay del tiempo en la música y qué hay de la música en el tiempo.

M - La música se desarrolla en el tiempo. El arte, el cine, el teatro.

Lo que pasa es que hay muchos tipos de tiempo. El tiempo es virtual. Está tu tiempo, vos cuando medís escuchás una música y buscás un tempo. Y por ahí no es tu tempo, lo tenés que adecuar al tempo que tiene la música. La vinculación sería que vos te tenés que adecuar al tempo de la música para entenderlo.

Los niños reaccionan con otro tiempos, sin embargo se pueden meter tranquilamente en una música a pesar que ellos tienen un tempo mucho más rápido, porque su corazón late más rápido. Son veloces, caminan más rápido.

I - ¿Ese tiempo es diferente al tiempo de la música? ¿Podríamos hablar de dos tiempos?

M - Sí.

I - ¿Cómo te parece que organizás una interpretación en el tiempo?

M - Y, creo que tiene que ver con el estilo que estás abordando, la época que estás tocando, que tienen distintos tempos característicos en cada época. Es más, en las partituras se nota, que está la redonda, los compases re largos, la unidad de tiempo la blanca y después la corchea, al final, terminamos con corcheas.

Uno o tiene que ir adecuando, a medida que va la obra hay momentos que hay espacios de tiempo, y se tiene que respetar tanto tiempo como silencio, también es muy importante el silencio. ¿que es la falta de tiempo el silencio?

Yo no conozco obras que tengan el tiempo tan riguroso el momento, siempre hay un rubato algún... (paura) Ahora me dejaste pensando.

Yo no sé si tocaría una misma obra al mismo tiempo cronológico, de reloj. Una obra de cinco minutos yo no se si me saldría en cinco minutos. No me importa tampoco.

Yo no lo organizo me parece, me dejo llevar. Como que ya lo tengo trabajado y si me pongo a controlar el tiempo pierdo lo otro. Pierdo la parte de la interpretación.

I - ¿Considerás que ese tiempo es el tiempo de otro?

M - No, es mío. A veces puedo llegar a cambiar ese tiempo. Si yo transgredo el tiempo, es una forma de decir. En ese caso yo primero estudio con el metrónomo, no para tocar con el metrónomo, sino para ver si estoy bien en los tiempos. Una vez que adapto eso, le tengo que dar el carácter. Y si ese carácter no se ajusta con lo que yo quiero hacer lo cambio. Pero muy mínimo va a ser. No va a ser una cosa que lo cambie del todo. Ahí viene lo expresivo, porque gracias a eso podés expresar también y no sea una obra siempre igual, sino tocaríamos todos igual.

Y aparte, el gesto, importantísimo. Como tomás un calderón, como tomás un rallentando.

Sí, sí, creo que eso es bastante libre y que el autor lo compuso con libertad. Sino lo hubiera puesto, en vez de rallentando, lo hubiera hecho con figuras rítmicas.

I - O sea que ese tiempo sería tuyo.

M - Sí.

(2)

I - ¿Cómo te parece que la música se vincula con el tiempo? Qué relación hay?

M - Basicamente es tiempo, el movimiento en el tiempo es como para mi lo más abstracto de la música: sonido y el movimiento que transcurre en el tiempo.

Siempre siento que ésta coordenada temporal (mueve la mano a lo largo de la mesa) que nos atraviesa, primero que es una de las cosas que más nos cuesta entender. Que les cuesta a los pibes entender. Bueno, uno largó un sonido y bueno ya está, ya empezó, pero no sé si lo pensé de siempre. No sé, pero a partir de que lo enseño es importante y sobre todo porque nosotros tenemos otra educación, una educación visual. 
(3)

I - ¿Cómo te sentís cuando estás en el tiempo de la músical?

M - Me parece que ahí entra la empatía, no? Con el carácter o el tipo de lo que vos estás tocando.

I - ¿Pensás que ese es tu tiempo?

M - Me parece que están las dos cosas. Porque es mi tiempo, porque es el tiempo que yo lo puedo hacer o lo siento o, me pasa por ejemplo esto que te digo como que a veces toco las cosas rápido porque soy ansiosa o porque tengo ese timing rápido.

Pero bueno, ese es mi tiempo pero no se si siempre respeto el tiempo del que lo escribió o de como lo escribió. Tampoco se si siempre estoy yo en ese tiempo que es mi tiempo solamente. Hay un tiempo personal y eso se lo imprimís a lo que vos toques. Ahora, si eso predomina siempre, no sé.

(4)

I - ¿Cuál es la relación entre la música y el tiempo?

M - ¿Sabés que es lo primero que se me viene a la cabeza? De que uno está horas y horas y horas estudiando para que después todo suceda en una hora, menos. Quince minutos, cinco minutos. Después a veces cuando uno toca le parece que pasó muy rápido todo y en realidad no, no es así. Es diferente el tiempo cuando uno escucha que cuando está haciendo el mensaje.

I - Entonces ¿cómo te sentís cuando estás en el tiempo de la música?

M - Y, depende la obra. Pero hay veces que como que uno está como agitado, como que se me acelera mucho todo el cuerpo y (obviamente hay cosas que demandan que eso suceda), y después lo escuchas con el tiempo y te das cuenta que estabas exagerando, o te estabas desbordando vos porque en realidad no se escucha eso.

(5)

I - Cuando tocás para otros ¿ese tiempo es compartido o es tu tiempo personal?

M - Lo estoy modificando a ese tiempo. Depende del estado de ánimo que tenga puede ser que cambie.

I - Entonces puede cambiar.

M - Sí. La interpretación de esos tempos internos puede ser que se acorten y se achiquen.

I - Y está mal que cambie?

$\mathrm{M}-$ No.

I - ¿Cómo te das cuenta si es compartido ese tiempo?

M - Y, si fluye la cosa... Hay públicos que son parcos. El público del teatro es muy parco y carapiedras. Pero en lo popular, no. En lo popular te das cuenta enseguida. Pero en lo otro realmente no sé. Y más cuando estás tocando con una orquesta, o estás con un grupo, están todos adoptando un mismo tiempo.

El caso del Himno, cuando tocás el Himno Nacional. Tocás el Himno a una velocidad y la gente no te sigue. Entonces te tenés que adaptar al público, para que siga. El objetivo ahí es cantar algo. Todos juntos. Entonces tenés que bajar un poquito. Los sigo a ellos. A la masa de voces. Y eso cuesta bastante, eh.

(6)

I - ¿Cómo organizás la obra en el tiempo?

M - Sí, a mi me genera... lo tengo todo como un mapa interno. Voy tocando una obra y ya se... Es como una obra de teatro, como un artista que sale al escenario y ya sabe lo que va a pasar en el segundo acto. Para mi pasa eso.

Además de estar en cada situación. Pero cada situación que uno está tocando, ya estoy pensando adónde se dirige eso. O sea la intención que pasa ahí está en función de lo que va a venir después. 
(7)

I - ¿Cómo te parece que se da la vinculación entre la música y el tiempo?

M - Sí, la música transcurre en el tiempo. Es una pavada que te digo, pavada gigante, lo digo por obviedad. Eso es lo que te obliga a estar en el presente. En un presente dimensionado, hacia atrás y hacia adelante.

Pero luego el tiempo es una vivencia. Por eso te digo que uno no transcurre todo el concierto igual. Te van pasando muchas cosas y te vas sintiendo también distinto. $Y$ esa es la relación que va teniendo esa continuidad de presentes.

$\mathrm{I}$ - ¿Te parece que ese tiempo es tuyo? ¿O es de otro?

M - Es mío. Soy yo la que le pongo el tiempo, soy yo la que transita los presentes. Es compartido, pero la determina es del que hace. Se construye compartido pero la determinación es de quien lo hace.

(8)

I - ¿Cómo te sentís cuando estás dentro del tiempo de la música?

M - Se me disparan muchas cosas con esto que me decís, porque me acordé de una obra que tardé un año en prepararla, y duraba cinco minutos. Y me acuerdo que cuando la toqué era como un placer de decir "terminé esta obra, duró cinco minutos, un año de trabajo" Y como que el tiempo ahí es como... es rara la dimensión del tiempo. Un año, cinco minutos, toda la vida de entender esa música, la toqué a los dieciocho años, ¡dieciocho años de entendimiento de esta obra! A los doce no la podía tocar. O si la tocase ahora, treinta años de entender esa música, un año de estudio y cinco minutos de realización. Es como que esos cinco minutos incluyen toda la vida en realidad, viste, es medio raro verlo así.

I - ¿Y ese tiempo es tu tiempo?

M - Sí, es mi tiempo.

I - ¿Y si la música es de otro?

M - Es mi tiempo igual. No, no, esa música es mía ya. Podría llegar a ser de otros.

(9)

I - Si pudieramos decir que hay un tiempo de la vida, que transcurre de cierta manera, y que la música podría llegar a ser otro tipo de tiempo, ¿cómo te sentís transitando por ese tiempo musical?

M - Para mi el tiempo musical es mucho más intensivo. Para mi hay una intención porque es un tiempo recortado y amplificado, ¿viste? Sí, yo creo que un tiempo musical, cuando hay una ejecución de una obra y todo, es de una intensidad superlativa, que la vida no la tiene. Para mí, no? La concentración sonora... sí, es catártica aparte.

I - ¿Te parece que ese es tu tiempo o de alguien más?

M - Yo te digo que sí, no lo he pensado ni lo he hablado con nadie en esos términos. Yo creo que sí.

I - ¿Puede ser compartido?

M - Sí. Con la misma intensidad, no sé. Pero sí.

(10)

I - ¿Cómo te parece que la música se vincula con el tiempo?

M - No lo tengo muy claro, pero me parece que es similar a... evocar las cosas buenas que sucedieron, que duran un tiempo. Bueno, la obra musical tiene un tiempo. Cuando te pegó esa obra, ese tiempo vos lo estirás, o tratás se sostenerlo, contenerlo, guardartelo... Pasa que al tener inteligencia y memoria, guardamos parte de eso... la música ya pasó, el hecho físico transcurre unos minutos, pero ese hecho físico deja deja como huellas, rastros que vos los podés evocar. No personalmente vivenciarlo, 
pero si algunas cosas que vas sacando de eso que te produjo y que a veces querés reproducirlo.

I - ¿Considerás que ese tiempo es el tiempo de otro?

M - No es algo que me preocupe si es mío o de otro. Yo me siento como interactuando en ese tiempo, sí. Yo soy un actor del tiempo, en ese momento de la obra, y hasta ahí llega mi comprensión del tiempo.

(11)

I - ¿Ese tiempo es tuyo o de otro?

M - No, de otro no. Mío, es mi tiempo. 


\section{APÉNDICE 3}

\section{Entrevista 3}

\section{Guión de la entrevista}

1. ¿Por qué elegiste ésta obra?

2. ¿Qué tipo de vínculo te une a ésta obra?

3. En ésta obra está el compositor... (completar según corresponda) y estás vos. ¿Cuánto de cada uno hay en tu interpretación?

4. ¿Cómo te sentís en el momento de tocar en público la obra?

5. ¿Te acordás de la primera vez que la interpretaste en público?

6. ¿Y ahora es lo mismo o te parece que cambió?

7. ¿Y cómo es volver a tocar la obra después de la primera vez en público?

8. ¿Podríamos decir que todas las interpretaciones de esta obra que hiciste en público fueron diferentes?

9. ¿Y cuál fue la mejor de todas?

10. Cuando volvés a retomar la obra ¿la retomás de donde la dejaste o arrancás de cero?

11. ¿Recibiste comentarios del público? ¿alguno que te haya llamado la atención?

12. ¿En qué etapa de tu interpretación de la obra / trabajo con la obra te parece que estás?

13. ¿Te parece que la obra cambió?

14. ¿Creés que vos también cambiaste? 


\section{Selección de pasajes de la entrevista organizados en temáticas ${ }^{81}$}

\section{Caso 1}

Instrumento: Guitarra

Obra: Tocatta, Fugue, Allegro

Compositor: Silvius Leopold Weiss

\section{El vínculo con la obra}

I - ¿Por qué elegiste esta obra?

M - Porque vos me habías dicho una pieza que tenga como algún grado de significancia importante, por ahí afectivo o personal, y ésta es una música que transcribí yo, es decir que hice un trabajo como de producción casi o de re-composición de la pieza que llevó bastante tiempo. Es decir, hace mucho tiempo que comparto con ésta música, como desde que empecé el proceso de transcripción hasta ahora. Al ser una pieza que retranscribí yo tiene como un poco de composición mía también, porque la adaptación de la pieza no es tal cual se toca en el instrumento para el que es original, sino que tiene cambios no sólo en la estructura de la música sino en la técnica para tocarla. Entonces tiene como mucha presencia personal mía la pieza, no es una pieza que compuse yo pero sí es una pieza que tiene un grado de arreglo fuerte mío. Además de que me gusta muchísimo la música digamos.

La pieza originalmente es para laúd barroco. Yo la conocí la música ésta en un disco de Eduardo Egüez, que es un laudista Argentino, un disco que se llama "Tombeau" donde toca ésta Suite -yo toqué recién como una parte de lo que es el comienzo de la Suite.

I - ¿Y hace cuánto que la escuchaste?

M - Hace mucho. Debe hacer capaz que ocho años, no sé.

I - ¿Y ya ahí querías tocar ésta pieza?

M - Sí, bueno a mi me había gustado, yo después de otras músicas de Weiss que también arreglé pero que estaban bastante más cerca del lenguaje de la guitarra, y siempre me encantó. Y después dió cosa que lo conocí a Egüez, pude hacer algunos cursos con él, -el vive en Italia ahora- hice cursos con él, después hice clases particulares con él, después estuve en su casa en Italia quedándome y haciendo clases con él ahí. Y bueno, la cosa se fue dando hasta que finalmente éste año hice unas clases con él en Mayo -acá en Buenos Aires- y trabajé éstas músicas, las músicas que habia escuchado y le conté esa misma historia digamos, que yo había conocido eso por él. $Y$ bueno, en cierto momento donde dije "bueno, a ver qué otra pieza Barroca hago fuera del repertorio tradicional de la guitarra de Barrocos" digamos y varios maestros me recomendaron: "bueno hacete una personal, transcribí una vos, que no haga nadie". Entonces bueno, buscando eso, ésta Suite me encantaba y en ese momento me acordé que me encantaba, y me puse a trabajar en esa hasta encontrarle la vuelta para adaptarla.

\section{Varias personas / Aspectos personales}

I - ¿Y hay una partitura para laúd?

81 En las transcripciones, las iniciales que se presentan antes de los diálogos identifican al entrevistador y al entrevistado entendidos respectivamente como investigador (I) y músico (M). 
M - Hay una tablatura para laúd, que es una cosa... (busca y me muestra). Son manuscritos, porque de Weiss no se... Weiss no editó su música, lo único que hay son manuscritos.

I - Qué te parece, ¿que te gusta la obra o que te gusta interpretarla?

M - Primero me gustaba escuchar la interpretación de Egüez, digamos, en el disco. Ahora me gusta interpretarla a mí. Pero va un poco unido de la mano, me gusta la estructura que tiene la pieza y me gusta el sentido que le doy yo. Que justo ahora hace poquito escuché de vuelta el disco de él -que ahora hacía un montón que no lo escuchaba-; desde que empecé a armar la pieza no lo escuché más, es una práctica que hago: una vez que empiezo a trabajar una música ya trato de no escuchar a otras grabaciones sobre eso. Y resultó ser que iba bastante por otro lado la versión que hacía Egüez, inclusive bastante por otro lado de algunas cosas que habiamos conversado cuando hicimos clase.

I - De cuando vos trabajaste la obra con él.

M - Sí.

I - En ésta obra hay varias personas, el compositor, el intérprete que escuchaste, y estás vos. En la versión que vos hacés ¿Cuánto de cada uno hay?

M - No, hay mucho de todos. Hay algo de Egüez o de -lo podríamos decir- el linaje de los laudistas, porque yo hice bastante estudio de perfeccionamiento con algunos laudistas (de hecho, todo este año tuve una beca sobre eso, no con Egüez sino con otro laudista que está en Buenos Aires que es Miguel de Olaso), entonces a raíz de eso estudié cosas del bajo contínuo, cosas del lenguaje como más profundo que lo que se conoce para un instrumentista que no se dedica exclusivamente a Barroco. Entonces, por ese lado sí, hay muchas... Ilegan muchas informaciones. Por otro lado hay muchas cosas del lenguaje Barroco que me sirvieron para hacer la adaptación, para la comprensión de la armonía y todo eso, que viene como por otro lado, por las escuelas donde yo aprendí armonía en todo caso, no sé. Y la interpretación final o parcial que hago en éste momento de esa obra es resultado de todo eso pero también es resultado de un montón de escuchas de música Barroca -no de ésta pieza en particular, sino de Barrocos de esa misma época, de formatos de comienzos de Suite tipo ésta-, de lectura de libros... Sí, está lógicamente mediado por un montón de personas.

\section{La preparación de la obra}

I - ¿Qué cosas hiciste?

M - Adapté de todo: voces que hubo que sacar, otras que hubo que poner, acordes que no podías hacer con la disposición que estaban, entonces había que reacomodarlos.

I - Igual, eso pasa con las obras...

M - ¿Con las obras que no son originales para la guitarra? Sí. Lo que pasa es que hay piezas que se adaptan más fácil, que vienen más cerca desde lo instrumental, es decir que más o menos vos ponés los dedos como dice la tablatura para un instrumento en el cual estaba hecho y es más o menos parecido que lo que vos podés hacer con la guitarra. Cuando en este caso el instrumento del que viene tiene ya una afinación que es muy distinta, tiene un registro que es mucho más grande hacia el grave bueno, la composición está hecha muy instrumentalmente en ese sentido, muy pensada para ese instrumento.

Un ejercicio que está bueno para siempre hacer es que, aunque suene cualquier cosa, leer la música así para ver como físicamente digamos iba en los dedos, que también es una manera de darte cuenta qué es lo que vale la pena poner en el arreglo y qué es lo que no.

//

M - En ésta siento que es de las que más puedo dar, porque el arreglo quedó muy bien para transmitirlo desde la guitarra, porque creo que tengo ahí unas ideas que están 
buenas, que están bastante bien organizadas, con las que estoy conforme en el modo en que se transmiten, un poco ésto también en el sentido del feedback que tengo con la gente que lo escucha, con la gente que para mi es "la referencia" de "a ver, yo lo escuché en el concierto cuando lo toqué, lo escuché después en la grabación del concierto, a ver ¿cómo escuchaste vos el comienzo de la fuga?”, ¿no? Entonces les pregunto a algunas personas: ¿Se escuchó bien tal cosa que te muestro ahora que yo quiero que pase o no? ¿se transmitió bien o quedó como... no se entendió? ¿acá conviene entonces tomar un poco más de tiempo, separar éstas cosas para que...? Esa referencia es muy importante para mí.

I - ¿Y por qué te grabás? ¿te estudiás después?

M - Sí, claro, me grabo justamente por eso. Porque además, en cada recital -como vos decías bien recién- después de que tocaste una hora y pico de música por ahí no te acordás los accidentes o las cosas que hay que mejorar para el recital de mañana, o de dos días o de la semana que viene, puntuales, no de la interpretación fina o de la versión que uno tiene sobre eso sino más bien sobre los accidentes que puede haber habido, entonces lo uso como un método de... que me facilite el trabajo. Yo me voy del recital con una idea de lo que pasó, por ahí me acuerdo de algunos puntos, "mirá que bueno que estuvo ésto" o "qué flojo que estuvo ésto" y después lo repaso en la grabación y me tomo notas: "esto que me pareció que estuvo bien, no estuvo tan bien" o "qué bolas, mirá el ruido que hice acá"... entonces me voy de hecho a estudiar esas cosas.

\section{Relaciones entre performances}

I - ¿Qué pasaría si escucharas ahora la primera vez que tocaste la obra?

M - Seguramente me parezca como más esquemático, tal vez. Así como menos fluído, menos directo, menos libre, menos cómodo seguro.

I - Pero más allá del "menos" o "más", que no es lo que me interesa, en la comparación de la obra en éste caso ¿cuán diferente te parece que sería?

$\mathrm{M}-\mathrm{Y}$, bastante diferente, sí. En un nivel de detalles, igualmente. Pero bastante diferente.

I - ¿Y vos? ¿cómo te parece que te verías vos?

M - Y yo también, probablemente porque. Eso -otra cosa que no dije antes y que para mí es importante-, cuando uno o cuando yo me voy escuchando y viendo varias veces con el mismo repertorio, yo escucho claramente y que yo le pongo la palabra como cuando estoy estudiando, cuán "convincente" se escucha o se ve. Más allá de que haya tenido más o menos errores. Pero es como que se escucha, y mucho más en un video, se ve como una confianza que se transmite ahí, y que lo hace que resulte más "efectivo" tal vez que otras veces que capaz que estuvo técnicamente mejor. Entonces, en ese sentido, probablemente ahora resulte convincente mi interpretación de ésta pieza en relación a esa primera vez.

\section{Retomar la obra}

I - ¿Cómo fue la primera vez que tocaste en público ésta obra?

M - Me parece que en Brasil fue el primer toque de ésta obra, en Mayo de éste año. En un recital en Porto Alegre o en Camboriú, uno de esos dos fue el primero, me parece.

Me sentía quizás un poco más tranquilo en el sentido que leía la pieza, es decir que tenía un soporte, un salvavidas extra, entonces la memoria quedaba ahí más cómodo. Muy también feliz porque estaba pudiendo poner esa obra en el programa, porque estaba pudiendo mostrarla, que hacía tiempo que la venía trabajando. También más alerta que con otras piezas, por ser una pieza nueva y por ser una pieza que, como primera vez o como primeras veces que la estás poniendo en un programa se pone a prueba ahí todo lo que -como te decía antes-todas las previsiones que vos hiciste. Por 
ejemplo, en el estudio "ésta digitación va bárbaro" y después en el recital te das cuenta que la tocaste una dos o tres veces y salió mal en las tres y bueno, no, "hay que arreglar eso", capaz que no es esa digitación o esa parte del arreglo no está bien hecha. Entonces, especialmente alerta, a todo lo que fuera a pasar.

I - ¿Y la situación en público cambia mucho? Como una interpretación entre tantas, ¿es importante en tu trabajo de la obra?

M - Sí, es importante porque me da pautas nuevas de cómo estoy yo con respecto a esa música. Desde un sentido técnico: tal arpegio, que en el momento en que armé bien la obra, que monté la obra lo estudié mucho, bueno de esa especificidad técnica después por ahí lo vas dejando ese trabajo técnico propio y bueno queda ese recurso aprendido pero a veces queda menos de ese recurso aprendido o a veces queda más, no se -es decir, lo podés hacer más rápido o te sale más cómodo más lento-, entonces ahí vas haciendo esos reajustes también: "bueno, si yo dejé de estudiar técnicamente ésto, bueno cuál es ahora el lugar en el que está".

I - Nunca arrancás de cero. ¿Se podría decir que vos tomás la obra cuando la dejaste o hay una vuelta atrás?

M - Y sí, la retomás desde dónde la dejaste. Pero si pasa mucho tiempo, como en el caso de la otra obra... porque ésta es una obra que está ahora en acompañamiento constante desde que la empecé a laburar hasta ahora bueno, nos hemos ido acompañando mutuamente todo el tiempo, digamos porque estuvo en todos los programas que toqué.

I - ¿Y si yo digo que la interpretación que hiciste hoy es una interpretación de la obra, pero también es una interpretación de la última interpretación que hiciste, que se va sobreinterpretando?

M - Sí, sí, podría ser una cosa así. Y también mediada por cómo estoy yo hoy.

\section{Indeterminación / El público}

I - ¿Vos que pensás que en el momento de tocar influye lo que está pasando en ese momento, que te puede llevar a decidir otra cosa?

M - Rara vez. Porque cuando vos decís interpretar, yo creo que en realidad uno tiene... digamos me hace ruido decir "tocar" como sinónimo de "interpretar". El hecho de la performance "in situ", el momento de la presentación de esa pieza me suena un poco difícil decirle a ese momento "interpretar", porque uno ahí pone o muestra la interpretación que ya hizo sobre ese... por eso yo le llamo más como la versión, que yo hago de esa interpretación.

I - ¿Entonces interpretar qué sería?

M - Yo lo llevo más al trabajo, a la construcción de la idea que uno va a mostrar sobre esa música, que puede tener pequeños matices en la versión en vivo - lo que querías hacer forte uno día lo hiciste más o menos, o no te salio ese forte, o lo que vos querías hacer más stacatto no salió tanto, o lo hiciste más ese día porque te sentiste más cómodo, mil variantes-, pero el trabajo de interpretación sería el de construcción de ésta piecita, o no sé, o en la vida en general.

I - Pero tuya?

M - Mía sí, claro. La interpretación sería la obra vista, a los ojos o vista, al criterio mío en éste caso.

Ahora, como completando ese canal de interpretación -y ahí vamos más a lo que puede estar percibiendo otro-, cuando yo construyo esa idea digamos, después la pienso en el sentido de "ok, yo entendí que yo acá quiero, no sé, que se escuche bien ésta línea de voces pero que no se pierda ésto, y que a la vez ésto sea un poco stacatto y que sí, tenga una continuidad de la frase anterior pero, si viene muy derecho no se va a entender o yo estoy gastando mucha energía y me va a complicar la frase siguiente", entonces empiezo a ver bueno, "el que está del otro lado, de toda ésta información que yo quiero mostrar, ¿qué es lo más importante para el que está del otro lado, para el oyente medio?, digamos", porque a la mayoría de la gente en general, con el repertorio de guitarra -salvo los guitarristas- cuando uno da un recital, siempre es la primera vez que escucha la música y quizás la única en la historia. Entonces como que sopesás ahí "bueno, de toda ésta data ¿qué es lo que puede ser más importante para 
transmitir?” o “¿qué es lo que estoy seguro que quiero que escuchen?”. Entonces ahí hacés otra vez un moldeo de eso y en todo caso, cuando vas al recital, depende cómo estás ese día -como te sentís en todos los aspectos: físico, mental, alimenticio, en todos- decís "hoy prefiero no joder tanto con ésto y dejar más claro ésto otro". En ese sentido sí, hago como re-adaptaciones de la interpretación ahí en vivo, digamos.

I - ¿Tenés como versiones?

M - Hay una versión general, que es lo que te decía antes, pero depende el día por ahí hacés ésto que te digo, "re-adaptaciones", que tienen que ver con "hoy no lo toco tan rápido" o "hoy me siento bárbaro, me doy rienda suelta, trato de no controlarme en ese sentido" o "ésta sala es más grande, más chica, más reverberante, más seca, entonces tomo decisiones en relación con eso", si es más reverberante me puedo dejar más tiempo entre un lugar y otro, es decir puedo tocar más lento, aunque no se perciba eso como más lento.

I - O sea que una vez que decidiste ese plan vas por ahí, ¿o puede ser que arrancaste de una manera y terminaste de otra?

M - También. Mirá, hay un guitarrista muy conocido que se llama Eduardo Fernández del que me contaban ésta anécdota que a mi me sirve mucho para tocar en vivo que es que "uno se da cuenta como va a ser el recital cuando se sienta ahí y toca la primera nota", es decir que descubre uno cómo estaba en realidad uno físicamente, como estaba tu sonido, si estaba bien alimentado antes, bien hidratado, si te está afectando mucho lo que está pasando ahí en el sentido malo o en el sentido bueno, si dormiste lo suficiente, sino. Ahí, pero cuando largás la primera nota. Es una cosa que a mi me sirve mucho, porque en general, para mi vida soy una persona muy previsora y eso para la música en vivo o para un arte performático es buenísimo en cierto sentido pero es muy frustrante en otro sentido porque siempre es un riesgo tocar porque va a pasar en ese momento lo que estás haciendo, lo que vos preparaste en mucho tiempo, o poco tiempo. Siempre que lo vas a tocar ahí quedás abierto a que ocurran un montón de cosas, buenas, mejores que antes, peores que antes, no sé. Entonces estar muy permeable a "bueno, ok, está bien, yo me voy a preparar lo mejor que yo pueda para cada vez pero llego ahí, me siento y empiezo a tocar y bueno, y ahí va a pasar un montón de cosas que yo no puedo preveer"

\section{Relación dinámica con la obra}

I - ¿Pero cómo es la mirada hacia la obra? A mi lo que me importa saber es si la interpretación es como la partitura, ya está hecho, nunca más... o si van habiendo diferentes... aunque no se logren técnicamente... ¿te vas planteando nuevas metas, o buscar una sonoridad, o cambiar algo?

M - En ese sentido, para mí es muy importante -y que es algo que cimenta mi confianza- es tener una interpretación clara de la pieza, como base que es lo que te sustenta -cuando como ahora, no la estás estudiando todo el tiempo, pero la pieza está ahí, te podés equivocar más o menos, tener un blanco de memoria pero donde vos pensás que la frase iba a ser así la hacés así-, entonces tener esa idea base es algo que para mí en la performance me da mucha confianza.

Además cuando hacés muchos recitales -desde ese momento hasta ahora- capaz que esa pieza la toqué como en treinta recitales, muchas condiciones distintas digamos, de mí: más en forma digamos más estudiado técnicamente o menos en forma. Ahora, con muchos recitales vos llevás esa versión a cada uno de esos recitales porque estás mostrando, no es que siempre tocás para la misma gente, entonces estás mostrando a cada uno eso que vos querés mostrar de esa obra. $Y$ el punto al que quiero ir con eso es que éstas piezas están yendo en proceso para una grabación también, es decir que yo estoy en vez de buscando otras ideas, más bien tratando de profundizar éstas ideas que yo ya tengo, por lo menos hasta el momento de hacer la grabación.

I - Pero igualmente aunque sea una idea implica ir cambiando lo que vas haciendo para llegar a eso. 
M - Sí, de hecho yo ya hice una grabación de ésta misma música en un video en Junio pasado y el mismo hecho de haber ese video a mi me dió unas pautas de qué estaba funcionando y que no ahí, para ajustar, pequeños ajustes "acá hay que esperar un poco más" "esto tenía que ser más rápido", eso. Que además, todos esos re-ajustes están buenos porque sino llega a un momento que es un poco aburrido tocar la música.

I - ¿Hay una necesidad que sea diferente?

M - Vas haciendo pequeños cambios. Ahora, si ésta pieza -como me ha pasado con otras"listo, la grabé", la presento para presentar ese disco, hago unos recitales más, "listo, la dejás". Dentro de cinco años, vuelvo y digo "uh, qué buena esa pieza que tocaba, la voy a armar otra vez", volvés, bueno seguro que ahí hay un montón de cambios. Por ejemplo ahora -justo lo que está acá en el atril- estoy retomando una música de Piazzolla que estudié cuando estaba cursando en la facultad. Agarré la partitura que tenía ahí y ya veo un montón de cosas distintas de las que yo había pensado y en principio veo también como un método de trabajo un poco deficiente, porque lo que hago ahora es: de todo lo que trabajo escribo mucho, pensando en ésto, para ver que va a pasar cuando yo vuelva a ésta idea dentro de un tiempo, o nunca, o a otra persona. Pero me encontré con una partitura con muy poca información mía, de qué pensaba sobre eso en el momento.

I - ¿Y qué cambió?

M - Y cambian muchas cosas. Cambia la sensación de control que tengo ahora. Estoy técnicamente mucho más fuerte y musicalmente mucho más fuerte que hace diez años. Entonces, ya descubrís un montón de cosas, y podés hacer un montón de cosas con más facilidad y más pronto, no sólo más rápido sino más pronto. Lo que en su momento me había llevado no sé cuánto tiempo poder armar, capaz que ahora en la primer sesión de estudio sobre eso ya viene solo.

I - Pero la obra no cambió.

M - No, la obra está ahí, no. Siempre el que cambia es uno.

I - Me interesa saber si la obra como algo sonoro va cambiando, en ésta obra en particular. Si desde la primera vez que la tocaste hubo modificaciones, por más pequeñas...

M - Si, las hubo. Ahora por ahí, poniéndome un poco más histórico, también la obra cambia en el sentido -por eso digo no solo personal sino histórico- en el sentido de la información que hay sobre eso, digamos. Hoy más o menos "se entiende" que tales gestos de la música del siglo XVII, de tal lugar, se hacen así o se hacen asá -para los estudiosos, digamos- pero por ahí mañana aparece un documento, la carta perdida de Weiss donde decía que no, que las tocattas en realidad eran rápidas, no eran lentas. $Y$ eso cambia la obra, digamos, no, según el conocimiento general que hay, o social de eso históricamente.

I - Y ésta obra la pensás seguir tocando ¿o ya la pensás...

M - No, porque todavía -esto que te digo- voy a grabarla... tiene todavía más recitales por hacer.

I - Y así como la obra tuvo como un movimiento temporal, a vos -puede ser con ésta o con otra- ¿qué te modificó a vos el trabajo con ésta obra?

M - Mucho, porque yo cuando hablo de una música o cuando me recomiendo a mí mismo "voy a empezar a estudiar ésta música" lo pienso como "a ver, con ésta música yo voy a compartir mucho tiempo". Entonces, como primera cosa tiene que ser algo que sea bastante sustancial, digamos ¿no? Si es una obra grande, con la que vos pensás compartir por lo menos un año de trabajo, bueno eso tiene que estar muy bueno, tiene que haber mucho ahi para discutir con la... con la obra, ¿no?. Entonces, en esa misma discusión, primero hacer una mirada tal, primero capaz como transcriptor o como analista de la obra un poco, después cuando la voy a hacer en vivo la obra las primeras veces bueno, aparecen un montón de cosas que en mi primera mirada, capaz que no estuvieron, o las pensaba de cierta manera y después vas y en vivo pasó, pasan otras cosas que tienen que ver con uno tocando en vivo que no funcionan tan bien con el "uno teórico" o "en casa". Entonces ahí te modifica lo que vos pensabas de eso. Y por 
ahí empezás a profundizar después en un sentido más desde el "fenómeno" musical o sonoro: "bueno, a ver ésto, ésta frase que yo entendía que era así ahora me doy cuenta que... es un poco... éste poquito distinto" pero que para la interpretación siempre es como grande, siempre es como el camino hacia una interpretación más "profesional", donde en los detalles está la calidad, digamos.

\section{Caso 2}

Instrumento: Piano

Obra: Eusebius 1

Compositor: Gerardo Gandini

\section{El vínculo con la obra}

I - ¿Por qué elegiste ésta obra?

M - Elegí yo la obra. Era un concierto que tenía mayormente música Argentina. Y es una obra que tiene una dificultad que es de mis fuertes y tiene facilidad en las cosas que no son mi fuertes, y hacía mucho que no tocaba... es una obra que es lenta, que tiene pocas notas, que no te pone en el riesgo de retomar técnicamente el piano. La disciplina de estudio así riguroso del instrumento nunca ha sido mi fuerte, mi fuerte es más lo musical. Y el Eusebius es una obra que está llena de sonoridades. Es una obra en la cual uno se regodea en el sonido propio del piano, en la superposición que tiene la obra, en la sonoridad, en la escala de dinámica (de $4 p$ a $1 p$, a un $\mathrm{mf}$ un $\mathrm{f}$ ), es una exploración tímbrica desde la primera nota hasta la última. Y eso por ahí es lo que a mi siempre me ha interesado como intérprete en realidad.

I - ¿Cómo es el vínculo que tenés con la obra? Si lo pudieras describir.

M - Y, lo que pasa es que la obra es sobre un danza de la 'Liga de David' de Schumann. Y para mí un compositor que me ha marcado mucho en términos de esa trama Schumanniana en el piano, no? De lo armónico puesto en una aparente simpleza con una profundidad de pocos compositores. Entonces era como un combo, no? Una obra sobre una pieza de Schumann corta, armónicamente más que interesante. Schumann tiene esas cosas, al igual que por ejemplo las danzas... las escenas infantiles. Son etéreas, que parecen de una simpleza y una liviandad, y por dentro tienen una profundidad, para mi en Schumann notorio, para mí es fascinante como compositor.

Y Gandini también. Porque Gandini para mí... yo no lo conocí, lo vi dos veces, no estudié con él, no estuve en la facultad cuando él estaba. Para mí Gandini ha sido un músico que unió esto que estaba tan separado y dividido: el compositor totalmente dividido, separado del intérprete. Y para mí Gandini fue músico, yo lo he visto dirigir, lo he visto tocar, y sus obras... y también tenía algunas cosas que no tenían que ver con la precisión, un tipo que hacía música popular, y para mi el perfil de Gandini es un perfil más que interesante. Lo cual, este grado de objetividad, disciplina y demás se mezcla constantemente con un grado de subjetividad, construcción subjetiva a partir de el decir musical, no? Entonces a mí... no es casual que Gandini elija un compositor como Schumann; para mí en ese punto, no? Yo me sentí muy identificada, porque uno en el fondo se identifica a través de lo sonoro, de la exploración un poquito en Schumann, al igual que por ejemplo en Debussy, ese mundo un poco... hasta autista, te digo, en el cual hay una envolvente sonora que está adentro tuyo y que vos la llevás, la hacés vibrar en algún momento hacia el otro -que en este caso es el público- como una onda en el agua, una piedra que vos tirás, ¿si? Y que vuelve otra vez a tu eje. Eso para mi es el tocar. Entonces por eso Gandini, por eso Schumann, por eso Debussy también. 
I - ¿Y que haya sido la obra con la que retomaste? Eso te generó algún afecto especial hacia la obra?

M - Si, yo la había estudiado antes con mi profesora, fue una etapa en el estudio muy linda que tuve, la trabajé con mucha rigurosidad con ella, la pensé, una obra que me gusta mucho... Se dió, viste, cuando vos decís "bueno" "ay, ¿tenés ganas de tocar el Eusebius?" "dale", y se dio. Sí. Y me vino muy bien tocarla varias veces. La última vez que la toqué la verdad que sí, me transporté completamente.

\section{Varias personas}

I - Habrían varias personas: está Schumann, está Gandini, estás vos. ¿Cuánto de cada uno te parece que hay en tu Eusebius?

M - Bueno, yo creo que más que nada hay de Gandini. A mi me pasaba algo muy raro cuando la retomé al estudiar, que cada tanto tocaba la de Schumann para volver a tener esa sensación y para traer esa circunstancia, no? Pero nunca las toqué en el mismo tempo. Para mí el más fuerte es Gandini en todo esto. Después Shumann y yo creo que lo que hago es interpretar lo que a mi me parece que Gandini quiso decir a través de Schumann. No se si lo hago bien o mal, pero sí es muy personal, eso sin duda alguna.

I - ¿Y por qué sería personal?

M - Bueno, son obras que tampoco son muy tocadas, pero no tiendo a escuchar yo versiones.

I - Serían como otras personas también.

M - Claro, yo me tomo la verdad la licencia. No son tempos tampoco impuestos tan claramente como para decir estás... entonces si la he tocado en distintos tempos dependía el momento también.

\section{La preparación de la obra}

I - ¿Y cuándo la trabajás?

M - Yo la trabajo en casa, la estudio, la toco más rápido, la toco más lenta, la mecanizo en cierta manera. Trato de no dejarme llevar por "ésta sonoridad" porque sino estás siempre... no. Mecanizada, anotar las cosas que tenga que anotar, fijar todos los parámetros, la dinámica propuesta, las notas, el tempo, la estructura del tres cuatro. En este caso hay una fuerte conexión con lo que es la métrica, un 3/4 que se escucha, tenés que pensarlo, cambiando el tempo empezás a escuchar otras cosas, y si lo tocás más rápido empezás a escuchar arcos gestuales expresivos muy distintos. La trabajo como una obra, si? Muchas veces vuelvo a tocar el Schumann y estudiar el Schumann para volver a... después el tema es el piano, yo trato -siempre digo, en ésta obra-, yo trato de probar un poco el piano pero no estudiar sobre el piano, salvo cuando la estudié acá que sí, la estudié con este piano. Probar, a ver cual va a ser el rango de dinámicas que voy a poder trabajar, por las características propias, por eso pruebo, tomo alguna cuestión también, para concentración a mi me sirve mucho pasar de un lugar a otro, incluso si hay ruido en la sala mejor porque estás probando concentración, muchas veces estamos muy cansados, así que está bueno eso, hacerlo desde ese lugar, lo pienso. $Y$ después, en cada momento que tocás es entrar en un estado diferente, esa es la idea, que siempre te sorprenda la obra.

\section{Relaciones entre performances}

I - ¿Y cómo es volver a tocar la obra después de la primera vez en público?

M - Lo que pasa es que esa obra es muy particular, por eso yo la disfruto mucho... Para mí cada vez que la toco es una versión completamente distinta, sobre la base de las 
mismas notas, y demás. $Y$, como te decía, que es un tema de sonoridades, es como que cada piano suena distinto, y yo pasé de tocar un piano de cola como el Petrof -que es ideal para una obra así- a un piano vertical en la casa Carlos Gardel, que no tenía nada que ver. Pero con el público mucho más cerca, entonces por ejemplo cambié las dinámicas, porque en realidad prioricé que la obra tuviera una unidad y que, si trabaja la sonoridad, el pianísimo acá va a ser un mezzo forte o un mezzo piano en otro piano para que tenga una envolvente similar a la que planteo por duración, por ejemplo. Por eso también modificás el tempo, porque tiene que ver con la respuesta del piano, ese piano particular.

I - Es una interpretación de la obra o es una interpretación de la última interpretación? Quizás sea muy rebuscado...

M - No, una interpretación de la obra. No, no es rebuscado. Porque yo en realidad lo planteo como... por más que tenga una maduración lo ves después, pero yo cada vez que la toco no me pongo a pensar "bueno, porque la otra vez...", no.

I - La otra vez un músico me decía que tenía su versión que mostraba concierto tras concierto, vos me estás diciendo todo lo contrario.

M - No es mi caso. Pero porque busco, por eso busco la obra, no todas las obras... o sea, está genial lo que dice. En este momento. Por ejemplo ahora vamos a hacer un homenaje a Coriún, entonces elegí una que es un tango en el cual todo es fortísimo y es la aridez de Aharonián, viste, esa nota que se repite... absolutamente distinto a lo de Gandini.

Porque tenés que modificar, sino es como que... un poquito te manejás de una manera muy casera. De alguna manera sos un profesional, tenés que tener una mirada más de profesional. Entonces buscar una obra con otras características, meterme en la historia de la persona. A mi me gusta mucho tocar música Argentina, para mí hay compositores de puta madre en la Argentina.

\section{Aspectos personales}

I - ¿Qué te parece que cada presentación le va aportando a esa relación que vos tenés con la obra? Que vos digas "cada vez que la toco...

$\mathrm{M}$ - La disfruto más.

I - Y a lo que sería la comprensión de la obra o la mirada de la obra, que le aporta?

M - Era lo que yo te decía, Matías, yo creo que uno lo va afianzando por dónde pasa el sostén discursivo de la obra. Y cuando ese sostén lo hacés propio y no lo pensás más, ahí es el momento mágico. Ahí el discurso sale solo. Que pasa mucho en la música contemporánea con lo cual, muchas obras... o sea, la exploración tímbrica no sostiene un discurso, en tal caso sostiene una estructura tímbrica que vos planteás, o sea como eso se da en el tiempo. Cuando la obra lo tiene y vos como intérprete lo podés captar en algún momento eso es maravilloso. Entonces "¿cuál va a ser el tempo", exactamente cuando es sólo la envolvente en ésta obra en particular, no?

I - Y esto de apropiarse de la obra que es de otro, ¿cómo se explica?

M - Y, es maravilloso. Porque en el fondo es como que te da el permiso, es simbólico lo que yo te digo, no?

I - Bueno, por ahí es una sensación.

M - Sí, pero vos ahí decís "Apa, sentirla propia", no? Porque te encuentra a vos. Me ha pasado con otras obras, me ha pasado con 'pasos sobre la nieve' de Debussy, algunas obras que siento que... no sé, que son... no sé, algo en particular, las siento completamente propias, mías, y me encanta.

\section{Retomar la obra}

I - Cuando volvés a retomar la obra ¿la retomás de donde la dejaste o arrancás de cero? 
M - No, si tengo poco tiempo lo que hago es tocarla en mi casa rápido a ver adónde me saltan todas.... entonces ahí trabajo, si? Trato de nunca trabajar en el área específico musical cuando estudio, porque sino hago mucha trampa, porque como yo tengo mi fuerte ahí la dibujo sea algo técnicamente, si la nota no suena. No. Entonces tengo que trabajar la rigurosidad técnica en ese punto, por más que sea una obra que no tenga velocidad tiene rigurosidad técnica en cuestiones, en lograr que suene la nota en un casi 'al niente' entonces bueno, ahí sí.

I - Me refiero a "ya tengo ésto" ¿o tenés que volver a plantear las cosas?

$\mathrm{M}$ - No, partís sobre una base que ya tenés.

\section{Indeterminación}

M - Si vos estás en una obra de complejidad técnica no queres escuchar porque todo te dispersa. Si te dispersa... A mi me pasó la última vez que estaba muy cansada y toqué el Eusebius y hubo tres notas y me equivoqué y decís "no, nadie se dió cuenta" Yo sí, me costó concentr... Bueno, pero no podía sost... No me puedo permitir desconcentrarme y no volver. No importa, me desconcentré y tengo que volver.

I - ¿Qué hiciste para volver?

$\mathrm{M}-Y$, me esforcé en volver. No quiero terminarla ya la obra.

I - ¿Y dónde te habías ido? ¿Qué pensás?

M - No, dije "ay, que c..., viste esta nota..." y empiezo a escuchar el sonido, y el intervalo y la sonoridad que no era y me deja de sonar el Schumann, me deja de sonar el Schumann... Y entonces armónicamente... si bien estoy tocando Gandini... me desconcentré y me volví a concentrar. Porque son poquitas notas... Y volví viste, y agrandé el gesto y toqué más forte, me escuché nuevamente.

I - ¿Te parece que alguien se dió cuenta de eso?

M - Cecilia, que me dijo "ah, pero salió bárbaro, no pero salió una versión Mónica divina". No porque ahí no se nota en mi cara, pero sí es interno, el enojo o la bronca, ya está.

\section{Relación dinámica con la obra}

I - ¿Y a la obra la seguís viendo de la misma manera?

M - No, yo a la obra siempre la veo... La última vez que la toqué dije "es un buen cierre de ésta obra", por lo menos por ahora, no? Porque yo creo que cuando lo tomás después de varios años más te sorprende nuevamente.

I - ¿Y cómo fue cambiando la mirada? ¿qué te parece?

M - La obra... siempre le encontrás algo nuevo...

Yo partí ya de un análisis de la obra. Sabía de qué se trataba, sabía como la había compuesto Gandini. Para mí la maduración te la da en que por ejemplo los gestos musicales fueron como mucho más claros sobre el final, que la obra se entiende mucho más, y es cuando encontrás justo el tempo. Y no te queda sólo la sonoridad, sino que se sostuvo el discurso mucho más. Creo que eso sí es notorio, porque la obra termina de entenderse en todo sentido. Entonces lo que para mí fue es que tuvo muchísima más claridad en el discurso musical.

I - Entonces si cambió tu percepción de la obra ¿Y a vos te aportó algo, te modificó haberla tocado?

M - Siempre te modifica. Por ejemplo, el Eusebius en el momento que yo estaba, personal hizo que me pueda adueñar de la obra, eso sí me pasó. Pero es una obra que se deja también.

I - Entonces hubo como una relación con la obra.

M - Sí, sí.

I - ¿En el sentido en el que juntos fueron transformándose?

M - Sí, para mí si. Es como el concepto más... digamos el concepto semiótico de la construcción textual, no? En ese punto. Sí, para mi es una obra que se dejo... primero 
uno siente aportes que le hace la obra, después uno realmente -en ésta obra- sentí que me apropié, la sentí como propia, incluso ésto de una versión que es mía. Y eso me gustó mucho. No me había pasado.

I - ¿Antes no?

M - No. Es fuerte, si.

\section{El público}

I - ¿Me dijiste que te habías emocionado la última vez que lo tocaste? ¿Qué pasó?

M - Y, me pasó eh... Bueno, me pasaron circunstancias personales... (...) Se juntan tantas cosas, no? Entonces fue emocionante. Estaba lleno de gente el lugar... y ahí hubo mucha gente sumamente respetuosa en la escucha, ¿no? Entonces... Y bueno, son esos días en que estás iluminada y que realmente... me desconcentré en un momento porque me equivoqué en una nota y vos decís "bueno, nadie se da cuenta" bueno, yo sí porque yo tengo el Schumann sonando todo el tiempo. Sí, para mí fue conmovedor. Eso, todo. Y son momentos eh.

I - Pero además la música no debería separarse de esos momentos. Está todo el tiempo, no?

M - No, no, sin lugar a dudas. Son momentos en los cuales hay un recorte de la vida, no?

M - En una de las veces -nunca es la misma versión-, un chico me dijo "qué bárbaro, vos el Eusebius lo tomás como una obra aparte del Schumann" y yo dije "obvio", viste (ríe). Es una obra sobre una obra de Schumann, no es el Schumann. Aunque diga que si tocás los cuatro a la vez suena... no va a sonar porque no es eso, viste. $Y$ es importante, viste, después vos le vas a encontrar otras cosas, otros tempis. Puede ser que ese día vengas más lento y empieces a tocar más lento y bueno, ¿cómo vas a sostener el discurso? Por ahí no fue tu elección. Eso te lo da el análisis de la obra, que es del compositor y cuál va a ser tu impronta. Es un juego constante (hace un gesto de ir y venir) Es un feedback entre el intérprete y el compositor.

I - ¿Y dónde está el compositor?

M - El compositor está todo el tiempo, puede estar en la sala también. Ahí bueno... (ríe).

I - ¿Cómo sería eso? ¿te parece de verdad o lo decís en chiste?

M - No, mirá, la primera vez que lo hice que vinieron Mariano y Cecilia y los dos me dijeron "hubo muchos momentos en los que estuvo Gerardo", ellos lo conocían... Y eso es lo mejor que te pueden decir. Se escuchó a Ge... Pero no necesariamente vas a conocer al compositor y todo, pero es importante que esté. Figurativamente, metafóricamente o realmente. Siempre en un ámbito contemporáneo, ¿no?

Bueno, por eso yo decía que la respuesta... Bueno, la respuesta acá en las jornadas fue muy... bueno, sí, por ahí para mí fue un poco exagerada. Algunas personas me han dicho que... gente grosa viste, vino una chica a decirme que le había conmovido profundamente la versión. A mí me gusta mucho cuando dicen "me conmovió profundamente 'tu' versión del Eusebius", entonces es ahí decís "chau, ah la pucha". Si, superlativo, por ahí un poquito exagerada, me parece, o por ahí son afectos míos... pero sí, gente muy grosa que sé que es muy hincha me han dicho que le había encantado, le había encantado la versión, sobre todo los compositores, ¿no? Por el manejo porque... por ahí hay intérpretes que tocan diez veces más y tocan fantástico, pero son más pianistas. Yo trato siempre de colocarme en un lugar de "ésta es en el instrumento que me fascina", tiene relaciones tímbricas impresionantes pero bueno, es la vía de comunicación musical.

I - ¿Y te llevás cosas de eso, te las llevás con vos? ¿forman parte de un bagaje de tu relación con la obra?

M - Sí. totalmente. 


\section{Caso 3}

Instrumento: Cello

Obra: Preludio de la Suite para Cello \#1

Compositor: Johann Sebastian Bach

\section{El vínculo con la obra}

I - ¿Por qué elegiste ésta obra?

M - Porque es una obra que toqué - posta- tanto que entre las obras que más... pensá que es una de las obras de Bach que primero ves cuando sos chico, de las primeras. Porque de las Suites es la más "fácil" técnicamente, así que la pasé desde mis épocas de estudiante a profesional, las pasé siempre con distintos... recién la toqué con un cello Barroco, que tiene cuerdas de tripa, que es un sonido más parecido a 1720 cuando se compuso. La toqué con mi cello cuando empezaba, con cuerdas de metal (canta) todo ligado escolástico, pasé a tocarlo como... Ahora lo abordo desde una forma histórica, que es por el lado que más estoy encarando la búsqueda artística, o sea que pasó por todos lados.

I - ¿Qué tipo de vínculo te une a ésta obra?

M - ¿Vínculo? De todo, me recuerda a mi maestro, porque la trabajé mucho con mi profe cuando era chico, las situaciones porque lo toqué en un montón de lados: en Francia, lo toqué en Brasil, lo toqué acá, en Córdoba, en Buenos Aires, Rosario, Santa Fe, Mendoza, en La Plata (mil veces en La Plata). La toqué tanto que es una obra que... no sé como explicar, la toqué tanto que me hace acordar a un montón de etapas de mi vida, porque como es una obra fácil de abordar técnicamente...

\section{Varias personas / Aspectos personales / La preparación de la obra}

I - ¿Qué te parece que le aportás vos con tu versión?

M - Bach es muy interesante -en éstas Suites- porque no hay un manuscrito de la obra. Lo que se tiene, que lo descubre Paul Casals a finales de 1800, son los manuscritos de la mujer, pero la partitura original no existe, no está. Por ende, es una obra que te permite -depende de cómo la abordes- muchas libertades a la hora de tocar, porque hay muchas cosas que no están claras, notas, arcos son un desastre -no tengo acá el urtext para mostrarte lo que es-, es un bardo, no se entiende nada, tenés que pasártelo porque no se entiende nada. Así que para mí es una obra que... inclusive vos la tocás acá, todos los cellistas tienen una versión super diferente.

¿Qué le aporto yo? Lo que trato hoy es una versión historicista, tratar de acercarse a lo que sonaba en la época. Por eso las cuerdas de tripa, por eso el arco Barroco, por eso algunas inflexiones, de tempo, de articulaciones que eran convenciones de la época. Hay gente que no, hay gente que no le interesa y está perfecto, son gustos. A mi me llena mucho más hacer una versión más fiel al estilo pero sin dejar también de lado el rol del intérprete, que en esa época... el rol del intérprete hoy en día es más máquina, bah, a medida que avanza la música se empieza a escribir todo, todo, todo-tocar esto piano, forte-. En 1700 no, eran convenciones, la parte estaba medio como guía y el intérprete medio que podía cambiar notas, hacer los arreglos que quisiera porque habia convenciones... (me explica). No se anotaba, pero bueno hay tratados que te hablan todo de eso. Así que también el rol del intérprete en esa época era más creador que el de ahora, el de ahora es más intérprete puro. Uno siempre le pone su impronta, porque nadie puede copiar sonido... 
I - En éste caso hay un compositor, un editor de la partitura y estás vos. ¿Cuánto de cada uno te parece que hay?

M - En esencia, trato que esté Bach, siempre. Los del medio no, no me interesa, usualmente no uso... trato de tocar incluso de memoria, no uso la parte más que para fines prácticos, de estudio. Estoy como en una puja porque sí, uno quiere poner siempre lo que... es más yo tengo una forma de tocar también muy particular que es como toco yo, que siempre me la han criticado mucho en concursos o cosas... Yo estoy chocho, a mi me gusta tocar como toco y no quiero imitar a nadie, puedo quedarme tranquilo que toco como me gusta y como siento, de alguna forma. Pero trato de alguna forma que esté presente Bach, el compositor es al fin y al cabo el que hizo la música, tiene que haber un respeto... no sé si es respeto la palabra... o sí, puede ser, como un respeto a lo que escribió también.

I - Y en la versión que a vos te gusta, ¿Cuánto de vos hay?

M - Trato que todo, si es para un concierto mío, un recital sí hago todo lo que quiero, trato. Inconscientemente uno siempre tiene, porque estamos formados en un sistema que te obliga a hacer cosas, siempre (que te obliga a tocar cosas así, así), pero bueno uno agarra eso, obviamente lo usa porque la estructura tiene que estar de alguna forma porque sino no podés tocar bien tu instrumento (ríe), pero después está también el criterio de uno, también va leyendo y se va informando. También no hay una forma sola de tocar algo, tenés tantas escuelas (los rusos, los alemanes, los franceses), tantas formas diferentes de tocar que al fin y al cabo, el que te va a juzgar va a decir "no, porque Mozart se toca así, pero bueno es como le enseñaron a esa persona que tiene que tocarse Mozart. O vas a Rusia y se toca de una forma que a mi no me gusta, pero bueno en Rusia todos tocan así y me parece perfecto. (...) Son todos criterios estéticos diferentes, por las escuelas, por los profesores que hubo. Vos pensá que tampoco hubo tantos profesores, el violín tiene una escuela mucho más avanzada, en cello tenés cuatro si no me equivoco. Y son alumnos de alumnos, más o menos una corriente.

Trato que sea un cien porciento, si es un concierto mío trato que sea un cien porciento, pero que sea mío no significa que esté dejando de lado al compositor, a eso voy. El compositor siempre está, y es lo primero porque estás haciendo su música, de alguna forma. Pero uno siempre tiene que ponerle un cien porciento de su impronta, me parece.

\section{Relaciones entre performances / Retomar la obra}

I - ¿Cada interpretación de ésta obra fue diferente?

M - Sí, por más que uno estudie para que salga de alguna forma "igual", nunca sale igual, siempre hay cosas diferentes. $Y$ uno también es diferente.

I - ¿Y qué te parece que se modificó?

$\mathrm{M}-\mathrm{Y}$, es una gran obra, la comprensión por ahí de la pieza, la comprensión de la música, no sé, eso más que nada. El fin para el cual uno toca, que como te decía esto de la inocencia de cuando uno era chico que toca por tocar y por eso va a buscar ese disfrute, y tocar para una competición o tocar para un concierto pago o un concierto que uno quiere organizar porque le gusta como que va cambiando mucho eso también. Así que cada vez siento que es diferente.

Es que Bach es magnifico, Bach es lo más grande que hay en ese sentido. Sí, en notas es re simple en realidad, pero no, tiene una profundidad mucho más grande que las notas nomás.

// 
I - ¿Qué te parece que es la interpretación?

M - La interpretación es las decisiones que uno toma a partir de un material, las decisiones que va a tomar a la hora de tocarlo, de alguna forma.

$\mathrm{I}$ - ¿Y cuando vos tocás en vivo qué hacés entonces?

M - Estás tocando, pero estás haciendo tu interpretación... Interpretación para mi viene de interpretar, de entender, yo lo veo de interpretar es entender. Cuando uno está tocando está mostrando lo que entiende y lo que siente de alguna forma para entender lo que está en el papel.

I - O sea que ¿podría haber una cosa más? Estaría la obra, habría otra cosa que sería como tu interpretación y además está lo que estás haciendo en el momento...

M - Sí, porque por más que vos tengas una forma también un montón de factores va a hacer que nunca te salga igual. Ojo, hay gente que sí puede tocar igual pero son esos medio máquina (ríe). Yo creo que sí va a ser diferente. Uno en general, a grandes rasgos, esto tiene su interpretación porque tiene su forma de entenderla, la música y las elecciones que va a tomar: "esto lo hago asi", "esto lo hago asá", pero sí, hay cosas, uno no puede tocar siempre igual.

I - ¿Te permitís revisar tu interpretación?

M - Me cuesta. Pero sí, trato... hay que hacerlo. Es difícil, porque cuando uno se acostumbra a algo y lo tiene tan seguro puede venir alguien que te dice "no, no es asi". Hay que entender que pueda ser de una escuela diferente y te lo diga, uno puede tomarlo o dejarlo, pero está bueno cuestionarse me parece: "¿y esto por qué lo hago así?" Por ahí uno lo hace inconscientemente. "¿Y esto por qué lo estás ligando acá?"

I - ¿Con ésta obra te pasó?

M - Sí. Pasa que Bach creo es lo más ambiguo en la interpretación que hay en el cello, en general.

I - ¿Qué pasaría si escucharas la primera versión?

M - Sí, es re lindo escuchar ... ¿Con qué te encontrarías? Con todo el recorrido que hiciste. A mi me pasaría eso, decir "wow, como progresás". O por ahí decir, recordar "mirá, acá estaba preocupado por pasar bien el arco", o tocar afinado, o poner bien los dedos, o por tocar directamente todo de corrido sin parar.

I - Comparemos ahora la primera versión con la última

M - Es como te decía hoy, el de la vara. Lo que te vas poniendo. Lo que me pongo ahora es poder hacerlo musical, poder hacerlo auténtico, poder... sí, hacerlo musical y auténtico, ya no pienso... si, la afinación, todo lo técnico siempre está pendiente porque es un instrumento sin trastes, nunca podés dejar de pensar en la afinación (ríe), o en lo técnico. Pero pasa a un segundo plano ya eso, pensas ya más en lo que es la música en sí, en poder conectarte... que en ese momento es re loco porque de chico te conectás... es diferente, yo creo que más que una conexión es como una adrenalina de estar tocando, no es una conexión tan profunda como la que podés tener ya cuando tenés una solvencia técnica y no tenés que pensar en...

Disfrutás de otra manera, pero yo creo que... y disfrutás también, pero yo creo que ahora son menos las veces pero son más intensas, las veces que pasa "sonás" así. Antes como que era así, era un estado más que un momento.

I - ¿Algo más que quieras decir?

M - Eso, que nunca terminás conforme (ríe). No conforme como algo, como que no estoy conforme, pero siempre vas mejorándola, vas... Ni siquiera la palabra es mejorándola, no sé cómo explicarlo, siempre va a cambiar, siempre va mutando este tipo de obras. Que por ahí una sonata... también... pero no tanto. Las sonatas -las sonatas de Beethoven, por ejemplo-, podes ir haciendo... mejorando cosas, pero yo creo que el repertorio solo es el que más evoluciona, el que más cambia y el que más constantemente te replanteás cosas. La música de cámara ya es otro mundo, me parece... si, es como que es otra... avanzás, vas mejorando todo, pero yo creo que 
donde más decisiones y todo tomás es en Bach para mí. Un solo totalmente. En la orquesta sos un engranaje, ni siquiera tenés tanto poder interpretativo, ¿no? Es genial igual la orquesta.

I - ¿Qué es lo que te motiva a volver a tocar una obra?

M - Y, la sensación que me da, cuando sale bien, y que decís "pucha, qué bueno". Eso más que nada, la sensación que te da cuando sale bien.

I - ¿Y cuánto de las anteriores hay en las nuevas? ¿arrancás desde cero?

M - No, no. Vas construyendo igual siempre, porque yo escucho por ahí grabaciones mías de hace dos años y las oculto de Youtube (ríe) por ejemplo, un montón, porque no me gustan. Porque uno constantemente va cambiando.

\section{Indeterminación}

I - ¿Cómo es la sensación cuando terminás de tocar?

M - ¿La sensación? Te sacás un peso de encima. Si salió bien, sí (ríe). Si salió bien es como si soltaras el aire. Y si salió mal, frustración. (ríe)

$\mathrm{I}-$ ¿Y si tenés momentos y momentos?

M - Tratás de no pensar en el momento que salió mal. Pasa igualmente después de tantas veces que la tocás que hay momentos que sale mejor y peor pero en general no suele salir tan mal si la tenés estudiada. Mal no sale. Por ahí cositas, feas, pero mal no suele salir igual. Pero te da bronca, es como que decís "p... madre". Pero igual seguís, tratás de no pensar eso y seguir. Sino se pincha.

I - En mi caso, no me interesa si sale mal, es como que la música se puede disfrutar igual.

M - Da bronca que algo que estudiaste tantas horas, quizás alguna pavada que sabías y no te sale te da bronca igual. Sí, pero va mucho más allá, si lo mirás el todo, un error contra doscientas notas que están bien, está bien.

I - También hay un riesgo que uno asume...

M - Sí, esa es la gracia de la música, a diferencia de las artes plásticas que es algo que ya está plasmado y va a quedar siempre, la música es algo que pasa en el momento y queda, salvo que grabes, que sea.. una música clásica usualmente es tocar en vivo, podés grabar pero lo más lindo de la música clásica es el concierto, ¿no? es algo único que queda ahí.

I - ¿Qué sentís cuando estás interpretando la obra?

M - Depende el momento, depende la situación, depende... muchas cosas. La acústica a mi me influye mucho, por ejemplo. Si estoy tocando en un lugar lindo, para tocar esta música para mí es en una iglesia. Un iglesia, o un lugar así muy reverberante es muy loco como eso te conecta, a mi me conecta mucho más, porque podés escuchar la unión de cómo se arman acordes con lo que vas tocando, porque en realidad esto que vas tocando son notas pero vas formando armonía y es.. acá por ahí más que la resonancia del cello no se escucha mucho, menos acá que es seco, lo tocás en una iglesia (canta) y es una bola... no sé como explicarlo, y aparte cada vez es diferente. Depende de qué tipo de concierto es, depende de cuán preparado esté; cuando estoy preparado disfruto mucho más, cuando sé que estoy tranquilo técnicamente, que estudié bien esa semana me relajo, fluye todo y siento a veces cosas muy lindas, de esas ganas de decir "pucha para esto está bueno estar vivo" (ríe). A veces no, no siempre está eso, es algo que creo también que lo vamos perdiendo a medida que somos más grandes. Cuando era chico me pasaba siempre que tocaba y "waaa" esa adrenalina que te da de tocar, que después uno la va perdiendo pero bueno... hay momentos que hay que buscar y los encuentra, no tanto como antes pero...

I - ¿Y vos? Más allá de la acústica...

M - Es que no siento siempre lo mismo. No puedo decirte algo porque depende mucho del contexto. 
I - Pero es algo personal... de afirmación personal...

M - Estoy pensando. Es que no te puedo decir una sola cosa. Ahora tocándola por ejemplo, y sí es una afirmación personal porque es una obra que sé que me sale, que la toqué tanto... pero no sé si es lo que me pasa siempre. No te podría decir que es algo que me pasa, porque es algo que es algo que depende mucho como esté, siento a veces mucha ternura tocándola o alguna conexión muy linda con la música... a veces no, a veces lo hago como un trámite -que es un bajón, pero bueno es laburo y no podemos evitar que a veces se convierta en un trámite- lamentablemente, me encantaría poder tocar siempre con la misma pasión pero hay veces que no podés.

\section{Relación dinámica con la obra}

I - ¿Y la obra va cambiando también? ¿la sentís de otra manera? ¿la conocés más?

M - La voy conoc... Sí, tal cual, la vas conociendo más, siempre le vas encontrando cosas... En Bach siempre vas encontrando cosas nuevas... distintas cosas... ya sea por ejemplo en articulaciones que pueden ser diferentes y pueden tener más o menos sentido, depende del momento, hay gente que toca articulaciones que vos decís... pero les sirven y tienen un sentido. No sé, armónicamente siempre podés encontrar cosas nuevas, por ejemplo. Siempre hay tanto detalle, tan encriptado, porque es música melódica, no es armonía; es armónico totalmente pero está escrito con notas, muy pocos acordes tenés, así que es música melódica pero puramente armónica, siempre estás descubriendo un enlace diferente cada vez que la vas tocando.

I - ¿Y pasa lo mismo con vos? (además de lo que ya me dijiste)

M - Uno va creciendo, va madurando también un montón de cosas...

I - ¿Pero ésta obra influye de alguna manera en esa maduración tuya?

M - La obra puntualmente no, porque es ésta y mil obras que uno va tocando. Es en general el recorrido que vas haciendo más allá de una obra puntual. Es más el oficio, el ir tocando... no te puedo decir que ésta obra... seguro que sí, porque la toqué tantas veces que seguro en cada una fui aprendiendo algo nuevo o encontrándome con distintas situaciones de exposición, pero no sé si puntualmente... ninguna obra te digo, por ahí. Como que son todas, porque no solamente tocás esto, tocás en orquestas, tocás música de cámara. Todo el recorrido que vas haciendo te va haciendo madurar y cambiar.

I - Entonces en general (y ya no de ésta música), ¿qué es lo que te permite ir madurando y conociendo de vos mismo?

M - Puede ser, entiendo que somos todos personas que estamos constantemente cambiando, no creo que seamos seres estáticos.

//

I - ¿En qué etapa de tu interpretación de la obra estás?

M - No, la interpretación está en una búsqueda, está profundizándose, siempre estás tratando... Yo creo que en ésta música nunca llegás a un.. algo que te convenza. Es más, fijate, los grandes solistas tienen como cinco grabaciones de Bach, siempre te van a decir "no, no escuches ésta porque no, no, yo no", siempre hasta que se mueren están grabandolo devuelta. Yo creo que nunca llegás a una satisfacción total. Sí podés llegar a decir "esto me gusta, está bueno" y representar a quien soy hoy y me gusta... la escuchás en cinco años y te querés matar quizás.

I - ¿Y la obra ya está cerrada o como músico pensás que siempre se puede...

M - La obra como obra, quizás como obra como de museo sí puede ser la partitura de las notas, pero la música no es eso. La obra en sí no es las notas nomás. Hay un montón de cosas que pasan más adentro de todo eso que no es el papel en sí para ponerlo en un museo y decir "la Suite \#1 de Bach", ponele, si se encontrara el manuscrito algún día. 
I - La motivación para tocar la obra ¿sigue siendo la misma que la primera vez que la tocaste? ¿o ahora tenés otras?

$M-Y$, otras. Más expectativa. Como que al principio es poder tocarla sin parar, poder hacerla entera sin parar. Después tocarla sin desafinar. Como que cada vez te vas poniendo más alta la vara. Primero es poder tocarla de corrido, por ejemplo, después como que vas sumando. Sí, las expectativas van cambiando a medida que vas avanzando me parece, son siempre más altas.

I - ¿Te parece que el intérprete tiene como una misión que es continuar el trabajo con la obra?

M - Sí, de alguna forma sí. Respetando -por ejemplo- lo que es la obra en sí: lo que es las notas o en general... si pone un "prestíssimo" no lo vas a tocar adagio. O sea, si querés podés hacerlo, está bien, buenísimo, pero no es... para mí no está bueno. Pero sí, seguís profundizando y seguís buscando otras vueltas, pensando también que la música evolucionó tanto que hay un montón de conceptos que nosotros tenemos ahora que quizás en esa época ni se pensaban, por ejemplo.

Ya por la temporalidad que tienen... son trescientos años casi... así que obviamente vas a seguir profundizando, vas a seguir buscando y descubriendo cosas nuevas porque también la música evolucionó y los intérpretes también evolucionaron un montón, la escuela, todo.

La música muerta como de museo, el papel, está bien y me parece que es super valioso. Pero la música puntualmente, más allá de eso es otra, no es eso puntualmente: es lo que cada uno le puede aportar, lo que uno puede hacer y lo que uno puede transmitir a partir de ese pedazo muerto de museo.

I - O sea que hoy en día no hay Bach si no hay otro... o sea, necesita que haya un otro que interprete Bach.

M - Y sí, y todos tocan Bach, aparte. Es lo magnífico, aparte cada versión es diferente. Yo en Spotify tengo como cinco versiones, y están todas buenísimas pero bueno, hay cosas que me gustan más de una personalmente... y es genial.

I - ¿Y por qué te parece que puede haber cinco versiones diferentes?

M - Y, por lo que yo te decía de las escuelas, por ejemplo, las escuelas tienen mucho que ver.

I - ¿Pero versiones tuyas son?

M - No, mías no, de gente que me gusta: Phoebe Carrai, tengo de Yo-Yo Ma ponele -que no me gusta, pero que está buena como versión romántica está buena-, de Barachmater, tengo varias versiones en Spotify. $Y$ son todas diferentes, inclusive casi todas son como también historicistas, pero dentro de la rama historicista también tenés también un montón de gente que hace cosas diferentes. También es algo muy nuevo, no tiene más de... cuarenta años tendrá como instaurado, treinta años, esto de tocar con cuerdas de tripa, con arco barroco, más arqueológico, la arqueología musical es más nuevo en realidad, así que tampoco hay una sola forma.

Pensá que en esa época tampoco está unificado, porque vos pensá que la afinación, por ejemplo dependía de cómo estaba el órgano del pueblo, así que podés tener un la que era un sol, una que era un si, un la bemol, un cuarto de tono más bajo... no había instaurado una afinación y tampoco criterios de cómo se tocaba cada cosa. No es como ahora que ponés youtube, encontrás todo y "acá está, se toca asi", no, cada uno tocaba diferente, así que hoy en día está pasando más o menos lo mismo también, y no está mal. Está bueno que pase.

\section{El público}

I - ¿Cuál fue la mejor de todas?

M - En La Plata, si, en el 2015, eso creo que fue lo mejorcito. Porque estuvo todo, estuvo afinado, estuvo musical, estuvo con los sentimientos, estuvo con conexión, el entorno era lindo, el concierto, la gente que estaba era gente muy querida. No sé, todo se dio 
lindo, la acústica, todo. O una en Tatuí, en Brasil que toqué en un museo, en un pueblito que está en la selva. Fue muy mágico todo, porque era realmente tocar para gente que quizás nunca había escuchado un cello. Y el grado de atención y la energía que ponían en escuchar era re copada.

I - Entonces pensemos, en un caso me dijiste muy querida, que no sé en qué influyó, vos me dirás...

$\mathrm{M}-\mathrm{Y}$, que no están juzgando, que van para apoyarte. $Y$ en el otro, gente totalmente desconocida que estaba en un lugar de espectador que está "asi" (muestra la posición de estar atendiendo) porque es la primera vez que escucha un cello, y que está como absorbiendo todo lo que estás dando, por así decirlo, y salió muy bien aparte por eso.

$\mathrm{I}$ - ¿Y vos cómo te sentiste en cada caso?

$\mathrm{M}-Y$, feliz. Porque pude hacerlo bien, me pude conectar con esto que te decía antes. $Y$ especialmente en ésta de Brasil contento porque la gente que estaba ahí lo recibió de una forma muy linda también, les gustó mucho.

I - Y cuando hay una experiencia así que vos te sentís muy bien, cuando volvés a tocar ¿tratás de...

M - Buscar, sí, ¿que pase de vuelta? Sí, trato de acordarme qué había sido el disparador de eso por así decirlo. $Y$ a veces sale, y a veces no. No hay fórmulas me parece, paso por paso.

I - Yo para tratar de ver como de una interpretación a la otra va pasando... como que el compositor ya la termino, pero para el músico es como un proyecto...

M - A largo plazo. Pasa que en la música académica hay que buscar algún tipo de estructura. Usualmente las elecciones que vos vas tomando no son porque sí. Como decía, que siempre hay tantas disposiciones de cómo tocarlo, siempre uno trata de que lo que va a hacer tenga -sobre todo en Bach, que tiene una forma muy estructurada de escribir- alguna, no te digo congruencia porque es como subjetivo, pero sí que lo que puedas hacer lo puedas justificar "esto elijo hacerlo así porque... que se yo, puede mantener el pedal y se escucha más disonancia de cómo va cambiando la armonía" por ejemplo, o puedo hacer ésta arco porque hay mucha gente que hace (canta) todo ligado, eso no tiene sentido (canta y explica como lo tocaría), me parece que tiene más fluidez, de alguna forma. Pero que es en siglo XX lo tocaba así y era convención...

I - ¿Cuál fue la interpretación más informal de ésta obra que realizaste?

M - En unas tertulias. Hay algunas tertulias que hacen con música clásica, así en un bar, que está toda la gente tomando algo. Está bueno, a mi me encantó el espacio.

I - ¿Y ahí estabas más consciente de lo que pasaba?

M - Y sí, porque escuchás ruidos, escuchás... la acústica es... seco, es un bar, que es más seco que acá. Pero pude hacerlo igual, pude disfrutarlo igual. El público fue re respetuoso pero es un bar, no podés evitar que "plin" los ruiditos de copas... o en Café Vinilo, ponele, se escucha igual todo eso. Pero hay un punto que si te conectás mucho no lo escuchás, no sos consciente también de eso, como que de alguna forma podés silenciarlo.

I - ¿Y ahí como sentís que están recibiendo la obra? ¿lo sentís diferente?

M - No siempre, porque me pasó en las tertulias que la gente estaban "asi" (hace el gesto de mirar con atención), y la gente le encantó, una señora se largó a llorar, fue re lindo también, la gente lo recibió super lindo también.

I - ¿Cómo te diste cuenta que estaba llorando?

M - No, me contaron después.

I - ¿Te dice cosas la gente después de tocar?

M - Sí, recibís cosas lindas. Después del cumple de un amigo. Hubo un concierto y después fuimos a comer y "que lindo", que le encanta y puntualmente algo así no...

I - Pero cuando te dijeron que se había puesto a llorar una señora... 
M - Bueno, eso sí me acuerdo, me puso contento saber que podés emocionar, que tenés la posibilidad e emocionar a la gente, eso sí. Queda como anecdótico, decir "pucha, que bueno que está, la posibilidad que tiene la música de tocar a la gente".

$\mathrm{I}-$ ¿Y vos alguna vez te lo planteaste a eso?

M - Si, siempre, que es re buen vehículo para llegar a la gente, la música. Principalmente para los chicos, por ejemplo las orquestas sociales. La música es un re buen vehículo, no sólo la música en sí para que sean músicos sino para aprender un montón de cosas de compartir, de valorar más el trabajo en equipo, del metodismo, la dedicación. Yo creo que de los que son proyectos sociales, los mejores son de música porque son yo creo los más integrales. Y eso lo vemos siempre los músicos que tocamos para la gente porque a la gente usualmente le gusta y lo recibe de una forma muy linda.

I - ¿Qué te parece que tiene de emoción la música? O ¿porqué es un vehículo emocional?

$\mathrm{M}-\mathrm{Y}$, porque uno inconscientemente relaciona un montón de sonidos con recuerdos. A mi me parece que lo que más mueve son recuerdos. Cosas buenas, cosas tristes, lo que más mueve la música es los recuerdos. Al menos a mí me pasa así: cuando estoy tocando algo, por ejemplo el segundo movimiento del concierto de Ravel, del concierto de piano, me pasa que es como re trágico pero lindo, pero tiene... me vienen un montón de recuerdos de sensaciones que me dieron situaciones... no sé como explicarlo, es como... Cuando sentís algo con la música estás de alguna forma reviviendo cosas que ya pasaron, por así decirlo a partir de un estímulo que te da la música. Cosas felices, cosas tristes, cosas nostálgicas, de todas las emociones que hay, creo que tenés música para todos todos todos los estados de ánimo, me parece.

I - O sea que no necesariamente son recuerdos con esa música...

M - Con esa música en sí puede ser que... por ejemplo el Concierto de Ravel lo toqué en una orquesta que me encantaba en Brasil, estaba re feliz... tocándolo me pasaba que recordaba otras cosas... aparte la energía que había en la orquesta todo... Ahora cada vez que lo escucho me acuerdo de lo que sentía esa vez cuando tocaba... Es como que es una cadena.

No se si te acordás puntualmente el recuerdo, así "puntualmente estaba acá", pero te acordás de lo que sentiste estando ahí, eso me parece más. Es más una memoria... una memoria emocional, más que de una memoria física, es más de acordarte que no sabes cuand.... pero que sentiste eso que te está generando la música. Eso es re loco. Ahora por ejemplo de haber tocado éste concierto que me encanta -buscalo después, el segundo movimiento del concierto de Ravel para piano en Sol mayor, el solo de corno inglés que está más o menos al final- ahora sí, cada vez que lo escucho pienso "qué buena gira", "qué lindo que la pasamos", "cómo los extraño a mis compañeros"... es como que te despierta cosas... te despierta sensaciones no puntualmente, de un recuerdo puntual sino sensaciones que ya seguramente viviste, las recordás de alguna forma.

I - ¿Y se te cruzan personas también?

M - Sí. Ahora cuando lo escucho se me vienen las caras por ejemplo de toda la gente con la que lo toqué en esa gira. Pero cuando la estábamos tocando, era la primera vez que lo tocaba así que no lo.... Pero aún así se me vinieron recuerdos... cosas personales... recuerdos... no se si recuerdos pero sensaciones estoy seguro que sentí en momentos, no puntualmente. Ahora después de haberla tocado y haberla agarrado como más o menos propia, porque la tocamos como cinco veces (ríe), en cada una era increíble porque en todas te emocionabas y se te ponían los ojos llorosos. Ahora sí, se me viene la gente que cuando estábamos tocando nos mirábamos, estábamos todos con las caras "asi", ahora una vez que la tocamos se me hizo propia de alguna forma y sí lo relaciono con eso. Pero hay mucha música que la tocás por primera vez y aún así te trae recuerdos. No se si es recuerdos la palabra, es "recuerdo emocional", te acordás, revivís la emoción que sentiste en algún momento de algo $X$ (equis). 


\section{Caso 4}

Instrumento: Cello

Obra: Suite para Cello \#3

Compositor: Johann Sebastian Bach

\section{El vínculo con la obra}

I - ¿Por qué elegiste ésta obra?

M - Yendo más a lo general, Bach es un compositor que a mí me atraviesa por varias cuestiones. Además, como es representante del género, del barroco como el exponente así más clave si se quiere. Y por la música, no sé. Tiene una relación para mí con... -icómo explicarlo!- como... que entrecruza lo humano con lo religioso y tiene una profundidad que habla también, o que describe en su música algo semejante a lo que a mi se me ocurre que tiene que ver con la esencia del hombre. Es un compositor que a mi me conmueve. Bueno, la suite que hizo para cello, me gustan todas, las seis y es una de las músicas que con el cello solo más me gusta tocar.

Me gusta el hecho que sea para cello solo, porque el repertorio para cello es más extenso en cello y piano, cello y orquesta... Me gustaba también tener... elegir una obra que sea para mí, que yo puedo contar; entonces es para mí, de mi propia experiencia, personal, digamos, con la obra. El armado es mío, no hay otra persona.

Y bueno, las suites por esa característica que te digo a mí es como que me atraviesan desde lo musical, desde lo afectivo, desde varios lugares. Entonces por eso se me ocurrió esa obra.

Yo toqué la tercera completa. Pensé en esa obra.

I - ¿Cómo es el vínculo que tenés con la obra? Si lo pudieras describir.

M - De tipo afectivo quizás, como que... Hay músicas que quizás son... no sé, como que uno se vincula desde otro lugar. Yo como que en mi estudio, en mi paso por el cello y en mi carrera -carrera no me gusta decir, pero en mi estudio- con el cello hay obras que a mi siempre me ha costado mucho abordar, todas por cuestiones técnicas. Bach es difícil técnicamente, pero como si... si yo pudiese en la música de Bach conectarme más rápidamente con lo musical que en otras músicas. No sé por qué, no puedo explicar por qué. De repente hay sí obras románticas, obras clásicas donde me parece, si se quiere, más trabajoso lidiar con las cosas técnicas, me cuesta más, me requiere más trabajo; y acá también me requiere más trabajo, pero la satisfacción que obtengo musicalmente es muchísimo mayor.

I - ¿Ya te gustaba desde antes o fue en el momento de tocarla que...?

M - No, en casa mi vieja las escuchaba y siempre hablaba de las Suites de Bach y... (ríe) para cello y tenía la versión de Rostropovich. También, eso también.

\section{Varias personas}

I - ¿Qué partitura tocás de la suite? ¿alguna en particular?

M - Estuve un montón de tiempo con la de Anna Magdalena, pero después encontré una versión que es de un alumno de Bach, que está buena también, que tiene unas articulaciones que están buenas. Igual, para mí son como todas sugerencias las articulaciones. Después, escucho versiones y las pongo yo, por lo general. Y siempre voy y tomo clases antes de tocarlo, siempre, me hago escuchar con alguien, siempre. Y no confío mucho sólo en mi perspectiva de las cosas.

I - En ésta obra estaría el compositor, Anna Magdalena (o de quién sea la partitura), estás vos... en éste caso quizás podríamos agregar a quien te está ayudando a armar la obra.

M - Sí, alguien que me escucha.

I - ¿Cuánto de cada uno hay? ¿hay lugar para todos en esa interpretación que hacés?

M - Sí, claro. Lo que es muy interesante pero yo no lo hice mucho, lo hice con éstas obras, es saber algo más del tipo, leer de la vida del tipo, qué fué... Es como que en la enseñanza en la interpretación como que hay una cierta sacralización del compositor, ¿viste? Como una transmisión de bueno, o yo crecí así, pensando en Beethoven como si fuese una palabra... o no sé, Bach es una palabra. Y de repente, sobre todo éstos 
últimos años, y sobre todo ligándome también un poco a la composición, empecé a ver a Bach, a éstos tipos como personas (ríe) y como artistas, y eso también es super interesante, porque la vida del loco. Yo no soy muy curiosa en ese punto, no me pongo a leer y a buscar, pero.. Que era religioso, que el tipo era recontra capo, organista... pero bueno yo lo empecé a ver más tirando para acá a los compositores como bueno "a ver ¿qué quiso el tipo acá?". Y sí, obvio que está, están un montón, lo cual no quiere decir que a veces está bueno también ser un poco insolente con la música del compositor, porque también está uno metido ahí en algún punto. Pero insolencia con criterio, porque... no sé, o con buen gusto, pasa que ahí entrás en la subjetividad: qué es el buen gusto, cómo lo pensás, desde dónde lo pensás... y es subjetivo, es lo que te gusta. Sí, ahí estoy yo, lo que me gusta a mí.

Sí, yo tengo mi forma, de una. Pero es todo un proce..., asumirse eso, y verse a uno también como uno mismo como intérprete... como sujeto creador, digamos. Es difícil. Porque a veces, "si, sos vos", pero en el proceso... habiendo sobre todo tantos referentes en el campo, decir "bueno, yo soy un intérprete" bueno... son como en algún punto palabras mayores, ¿no? Bueno, yo hago lo que puedo, con la música que tengo, con lo que me tocó, con lo que elegí hacer. Y sí, estoy yo, están mis limitaciones, y están mis virtudes también, está todo, bueno, y es lo que soy yo. Pero aceptar eso y sobre todo arriba del escenario es un proceso que tiene más que ver con la vida (ríe) que con la música, bueno que está todo ligado, ¿no? Pero bueno, ya te digo, para mi, como ligarme a la composición y a eso, a esa actividad por ahí... sí, al análisis sobre todo, me hizo dar cuenta de "a ver, ¿éste tipo que quería acá?", "¿por qué", "mirá que capo", "mirá lo que hizo", que se yo. Y estoy en eso todavía. Estoy como descubriendo ese mundo, es como incipiente. Porque yo en lo personal, durante mucho tiempo fui... yo quería tocar mejor el violoncello, como instrumentista, técnica, técnica, desarrollo técnico, escalas, arpegios, estudios. Y las obras mismo desde el punto de vista técnico, como... relegando un poco, porque yo empecé de grande a tocar el cello. Entonces como pa pa pa, mucho ese laburo. Y te podría decir como que recién ahora se está juntando como la parte más creativa, si se quiere, más de búsqueda y más lúdica con esa cuestión de laburo que para mi fue un esfuerzo muy grande, muy técnico. Y con Bach es algo que enseguida, conecta... con Bach eso fue lo que me pasó, como que... conecto, viste, como que conecto, no me importa si está desafinado porque la línea y todo, como el tipo maneja el contrapunto en la línea melódica, viste que pla pla pla pla. No sé, tiene algo, bueno (ríe). El tipo un capo, todo el desarrollo del contrapunto que hace es increíble. Eso me pasó, cuando se la llevaba a mi profesor, con él yo analizaba un montón.

\section{La preparación de la obra}

M - Algo muy interesante para mí fue descubrir que había varias vertientes en la interpretación de esa música. Como, con cello moderno, con arco moderno, con cello barroco, con arco barroco, cuerda de tripa, cuerda de metal. $Y$ todo ese mundo de como... de las diferentes cosas que me devolvía en instrumento con las diferentes recursos, diferentes arcos, cuerdas, que se yo, fue como también un descubrimiento y eso me atrajo también. Bueno a ver, como suena una suite con tales recursos, como suena una suite con tales otros, que se yo. $Y$ en casa se escuchaba todo el tiempo.

$\mathrm{I}-$ ¿Y lo tocaste con diferentes instrumentos?

M - Sí. Primero con el cello moderno sí, chusmetié, toque alguna, con cello moderno, arco moderno y después con un cellista -que ya tocaba cello barroco de antes- empecé a probar: primero con cuerdas de tripa (instrumento moderno con cuerdas de tripa), después con el arco barroco, después con arco barroco y cuerdas de metal, y ahora tengo el arco barroco, el cello barroco ya todo con cadena, puente, todo barroco. $Y$ bueno, también es otro mundo que se abre.

I - ¿Y cambia algo? Con respecto a vincularte con la obra.

M - Sí mucho. Sobre todo cambia mucho con el arco. Lo que pasa es que con el arco es más fácil hacer ciertas articulaciones y ciertas cosas, o mismo la postura, todo es diferente y me es más natural, esa es la palabra. Igual, también era como re lindo tocarla antes con el instrumento moderno, pero bueno, eso le sumo algo curioso quizás como algo que en lo que me gustó profundizar.

I - ¿Te acordás de la primera vez que la interpretaste en público? Cómo te sentías en ese momento, las expectativas que traías... 
M - El año pasado fue que la toqué completa. Sí había tocado números separados antes, pero completa el año pasado. Y nada, con un julepe bárbaro. Era tocar la tercera completa. Yo había tocado la segunda completa... (...) Y la tercera tenía esa característica... es diferente. Como si fuera, yo me la imagino como más gorda. La segunda es profundidad y la tercera es como peso, viste, para mí, más pesada y más... sobre todo el preludio, que es difícil y tiene como.. Necesitás como estar todo el tiempo como en tensión, como todo el tiempo tocando. Y para la primera vez que la toqué, me hice escuchar, estuve yendo con un maestro, que me encantó que me escuche, estuvo re bueno y laburé mucho, laburé todos los números bastante. Y bueno, estaba confiada porque había estudiado un montón, y había tomado clases. Eso me dejaba... las clases me ayudan un montón.

Yo en general me pongo muy nerviosa antes de tocar. No sólo el momento antes sino los días antes, quizás cuando tengo una fecha semanas antes, cuando sé que tengo esa responsabilidad y que me queda todo un montón de tiempo, y que ese tiempo lo tengo que usar para estudiar. Esas semanas antes me recontra re estreso. Digo "no, tengo que estudiar, tengo que estudiar", me agarra nerviosismo. Ahora, en el momento en el que yo entro con mi cello, me siento y toco soy feliz. Lo que pasa es que son veinte minutos de felicidad (ríe) para no sé cuántas horas de laburo en tu casa.

\section{Relación entre performances}

I - ¿Cómo te sentís en el momento de tocar la obra? En público, por ejemplo.

M - Diferente cada vez. Porque, si es la primera vez, como muchísima más responsabilidad, y yo por lo general toco de memoria, nunca toco con parte, entonces la tercera dura como veinte, veinticinco minutos. Si es la primera es como "a ver qué pasa", qué es lo que me pasa con ésto, que es nuevo, si es la primera es como con mucha más responsabilidad. Viste, es como que no sabés como vas a estar, pero a su vez también tenés un montón de licencias, decís "bueno, es la primera vez que la estoy tocando" (ríe), pero bueno, yo quiero que esté siempre bien. Y después, en la medida que lo vas repitiendo, yo lo voy como naturalizando a esa situación y me encuentro con quizás otras dificultades, en la medida que lo voy tocando. Digamos, como la resignificás la obra la otra vez que la tocás, cuál es el recorrido que la obra hace adentro tuyo digamos.

\section{Aspectos personales}

I - ¿Y en el momento cómo arrancás? Por ejemplo, ahí la primer nota...

M - Y ya ahí trato como de construir un cierto personaje. De focalizar los pensamientos, sobre todo depende el carácter. En la tercera era "bueno, listo, acá estoy yo", empezaba (canta) una escala de do mayor. Pla! Do Mayor así, tomá! Pla! (ríe) Es así. Entonces como bueno un poco ese lugar. Desde ese lugar, de construir un personaje en mi cabeza. Y lo que siempre pasa es que al principio estás tenso y después te aflojás.

I - ¿A qué te referís con personaje?

M - Como una construcción en el pensamiento y... en algo emocional, si se quiere, en algún tipo de emoción. No lo suelo racionalizar mucho porque me choca mucho pensar "ah, esto es dulce" "acá estás enojado" "acá estás triste". Me parece que la música va mucho más allá de ese tipo de descripciones, pero si lo que trato es de sentir yo lo que la música me sugiere. Tratar de generar eso que la música me sugiere adentro mío. Quizás ese sea el personaje: ¿qué es lo que siento yo con esto? Bueno, lo reproduzco. Porque el estudio muchas veces de la obra en mi casa es técnico (técnico, técnico, técnico), y en algunos momentos conecto con la música, como largándome, pero no la largo muchas veces la obra antes de tocarla, no la largo igual que en el concierto, no lo hago mucho eso.

I - Te reservás ese momento para...

M - Claro.

I - ¿Y pensás antes como lo podés hacer, por más que no lo hagas?

M - Quizás lo pruebo, sí, lo hago, pero por fragmentos: "acá esto, acá lo otro, como quiero que sea esto, como quiero que sea lo otro", por fragmentos, no en su totalidad. La toco entera, obvio que la toco entera, pero no la toco entera un montón de veces, la toco entera un par de veces. Y como que ese momento, que ya de por sí tiene algo 
especial, bueno como guardar eso viste. Además no es lo mismo, vos podés simular eso de personaje en tu casa, pero si vos tenés la gente adelante ya está, es otra cosa, porque la gente hace que se complete algo que sino... no, para mi no se completa, si no está la gente que te escucha. Eso es glorioso.

\section{Retomar la obra}

I - ¿Y cuando tuviste que tocarla por segunda vez tuviste en cuenta cosas que habían ocurrido en la primera?

M - Sí, lo que me pasó es que no fue inmediato tocarla de nuevo, fue al tiempo. Entonces como que la percepción de la primera ya estaba como medio desaparecida.

La obra madura cuando no la tocás. Por ahí vos le das, y le das, y le das un mes entero "pla, pla, pla". La tocás, bueno, tenés un resultado. La dejás de tocar, la agarrás al mes y creció.

I - ¿Y vos también maduraste algo en ese tiempo o es sólo la obra?

Si, evidentemente yo también en algún punto. Pero... está bueno, porque hay cosas como que suceden en el... con relación a esto que yo te decía antes, hay cosas que suceden en el plano de algo como tácito, que no está como explícito, ¿por qué la obra madura sin tocarla? Como que hay algo bueno, como de lo psicológico, de la psiquis misma, bueno la cosa está ahí y madura. Si la estás laburando es una cosa, pero después que se asienten esos procesos que uno labura a veces lleva un tiempo que ese mismo tiempo. Por eso, yo le di un saque, le podés dar un saque, me pasó mucho con los conciertos para los concursos: le das un saque a un concierto para un concurso, lo tocás de esa manera pero jno podés más que eso! porque vos sos ese en ese momento y estás atravesado por tal y cual circunstancia y le diste, le diste... Después la dejás, y eso que vos hiciste en algún punto queda, y se elabora, se elabora no estándole encima a la obra.

I - Y cuando volvés a tocar la obra, esa motivación de hacerla ¿en qué cambia con respecto a la primera?

M - En la segunda, uno espera estar quizás un poco más suelto, porque ya la tocaste una vez.

I - ¿Pero retomás cosas de la primera?

M - Sí. Y salen nuevas también.

I - ¿Arrancás de cero?

$\mathrm{M}-$ No.

I - O sea, es una construcción sobre la anterior.

M - Claro. La retomo y digo "qué cosas acá pueden permanecer", "qué cosas pueden cambiar". Como que al retomarla hay mucho de lo anterior pero salen cosas nuevas que tienen que ver con otras experiencias de otros lados. Para mi es como que hinchar sobre lo mismo, lo mismo, lo mismo es como que no te nutre. Hiciste un laburo con otras cosas, con otras músicas, que se yo; de repente volvés y suceden otras diferentes.

\section{Indeterminación}

I - Sobre todo la carrera de instrumentista que es un poco competitiva a veces....

M - Sí, recontra. Como aceptar que eso sos vos en ese momento. Nada más que eso.

I - Y, uno tampoco es el mismo siempre.

M - Claro. Pero es que todo eso ha ido cambiando. Siempre. Y además eso, el recorrido con el instrumento es como un simil recorrido con la vida, viste, en ese sentido. Aceptar eso, aceptar como que uno no tiene el control de las cosas, muchas veces de lo que te va a pasar... Eso me acuerdo, cuando yo era muy chica me ponía muy mal. Porque hay días en los que uno está como pez en el agua con el cello, y hay días que no pegás una, que sentís que decís "no puedo". Con el cello y con cualquier... no sé, a mi me pasa así. Capaz que a otro tipo no le pasa... Y siempre está la incertidumbre de cómo va a ser el día que vos tengas que tocar eso. Que no sabés. Y yo en un momento fui recontra obsesiva del estudio riguroso y obsesivo también para tener lo más estudiado para que esa variable me afectase lo menos posible, pero tenía el culo así fruncido entendes? (ríe). No sentía disfrutar en un $100 \%$ con ese resultado. Y eso fue mutando también, como decir "ya tengo un recorrido con el instrumento", voy a 
hacer con responsabilidad lo que tengo que hacer. Pero hay algo, un factor ahí que a mí me excede, que yo no puedo estar controlando y no quiero además. Porque me vuelvo loca estudiando los pasajes a negra 30 con el metrónomo, cambiándole los ritmos, los acentos, con nota pedal... ino tengo ganas! Yo no tengo más ganas. Entonces aceptar ese no control de las cosas es análogo para mi con un montón de cosas de la vida también. A mi se me ha dado muy claro con el instrumento es muy en paralelo con el descubrimiento de un montón de cosas en otros planos que no son exclusivamente de la interpretación. Por eso ahora no es lo mismo para mí estudiar algo nuevo, como que lo dejo, dejo una cosa al azar. Y antes no. Antes también lo dejaba al azar, pero pensaba que no, pensaba que yo lo podía controlar. Bueno ahora // sé que no puedo controlar lo que pase ese día.

M - La última vez, en la repetición de la Giga, cuando repetí, en vez de ir a la dominante -o sea, no sé que hice al final-, cuando repetí la segunda parte terminé con el final de la primera pero fui a la dominante de la segunda... o sea, hice toda una repetición mal pero armónicamente pasable. Y mi amigo cellista me decía "qué hija de p..., porque no fue que te trastabillaste, fue que hiciste armónicamente mal la cosa.." Y seguí, me acuerdo. Como que estuvo bueno eso de... O sea, terminé en otro lado, me fui como al c... y agarré la segunda y ipla! en el momento y seguí. Eso me dijo mi amigo. Como que no se notó por eso, porque armónicamente había una coherencia pero estaba mal lo que estaba tocando (ríe).

\section{Relación dinámica con la obra}

I - ¿En qué etapa de tu interpretación de la obra / trabajo con la obra te parece que estás?

M - No, para mí es como... nunca terminás. De hecho Yo Yo Ma no sé cuántas veces la grabó. Hay ochenta mil versiones, como que tenés toda la vida para grabarla veinte veces si querés.

Yo es como que toqué la tercera y ahora estoy queriendo avanzar con la cuarta, estoy así digamos. Quiero hacer la cuarta completa, la quinta completa, la sexta no sé (ríe) pero... hasta ahí. Estoy en otra Suite. Si hay un acercamiento posterior... Me parece que está bueno pasar por las otras Suites para volver a ésta.

I - Hoy me dijiste anteriormente que había como un recorrido con el instrumento que tenía que ver con la vida. Si en el lugar de con el instrumento lo pudiéramos pensar con ésta obra, ¿dónde te encontró ésta obra y dónde...? O si te modificó algo como intérprete.

M - A mi me encontró como en un momento bisagra, de buscar el goce de tocar por encima del laburo técnico. Con ésta obra encontré un poder explayarme musicalmente como más a gusto y más espontáneamente, si se quiere. Y me agarra en el momento bisagra donde yo necesitaba conectar con el cello desde un lugar más lúdico. Y fue una obra que me permitió amalgamar las dos cosas.

I - Y desde tu interpretación de la obra, ¿la seguís viendo de la misma manera, o pensás que se modificó en algo?

No sé, más me transformó a mí de lo que yo a la obra. No es lo mismo para mí pero porque yo no soy lo mismo. La obra es lo mismo. Con esa obra no me pasó. Quizás la sacralizo un poco, es como si se quiere intocable. Con otras obras sí me ha pasado, me encontré tocándolas en otros tempos, diferentes, porque no me cerraban los anteriores. Pero eso como que tiene una unidad para mí que es estable, o algo que es estable; que los cambios que yo le pueda hacer tienen que ver más con sutilezas, como más delicadas que quizás se puedan ampliar más en las últimas interpretaciones, pero sutilezas. Para mí si hay algo que ha ganado en mi interpretación de la obra quizás un poco más de sensibilidad, no tanto técnico, como más detalles, a medida que la suelto va ganando en detalles la obra. No sé, igual hay que preguntarle al que la escuchó (ríe).

I - Pero al ir a los detalles a mi me hace pensar que en realidad estás profundizando en la obra.

M - Claro sí.

I - A mi lo que me interesa saber es si entre la obra y vos se genera como una relación a lo largo del tiempo, como una relación temporal entre vos y la obra. 
M - Claro, sí, como una resultante que siempre es diferente. Si, no, de una, eso sí, más vale. Pero porque uno es diferente (ríe).

(...)

I - Pero vos también buscás eso, según me contaste antes. Como que ya estás pensando en cambiar... la interpretación.

M - Cambiar cosas, sí.

I - ¿Eso también sería como creativo entonces?

M - Es creativo, claro, sí, más vale que es creativo. Vos tocás una obra de nuevo y decís "ahora le voy a hacer ésto", "ahora le voy a cambiar lo otro", "ahora el fraseo quiero que sea de ésta manera". Obvio que hay un proceso creativo ahí, tal cual.

\section{El público}

I - ¿Recibiste comentarios del público, alguno que te haya llamado la atención?

M - En general todos buenos comentarios. ¿Alguno en particular? No, no me acuerdo en particular.

Un director que fue a escuchar en La Plata me preguntó hace cuánto que yo tocaba cello barroco, porque el vivía en Italia. Viste que allá la movida de la música antigua, los instrumentos antiguos está como mucho más en auge. Me preguntó dónde había estudiado y yo le dije que había estudiado acá, que había aprendido, que había visto videos. Y me dijo que le había gustado mucho, que parecía como que tenía un dominio por sobre el cello barroco. Y eso me gustó, que me diga eso. (ríe) Eso fue algo bueno.

I - ¿Podríamos decir que todas las interpretaciones de esta obra que hiciste en público fueron diferentes?

M - Si. Hay públicos más amigos y públicos más distantes, y que te hacen sentir mejor. Igual, siempre que he tocado ésta obra en general hablo un poco y explico antes. Siempre. De Bach, un poco de la Suite, de la seis, de lo que hace Bach, el laburo del contrapunto, asi para la vecina, la que es contadora.

I - ¿Y cuál es la intención de eso?

$\mathrm{M}$ - Y, como que haya un acercamiento no solo... como naturalizar un poco la instancia más de la audición. Como que haya un acercamiento no sólo desde el sonido, desde la música sino también algo introductorio. No siempre me gusta hacerlo, pero con Bach como que me gustaba: "es un instrumento solo pero tiene un desarrollo que se llama contrapunto a voces", "porque hay una voz y pasa esto", "escuchen que yo voy a tratar de hacer esto", que se yo, "son reminiscencias a danzas, la Alemanda era una danza, la Courante era una danza", algo introductorio porque es un instrumento solo que son veinte minutos tocando que por ahí es medio moplo, viste.

I - No se da mucho que los intérpretes hablen.

M - No. Sí, a mi me gusta.

I - Es diferente del intérprete que entra serio o medio creído, no mira al público.

M - Claro, no a mi eso no me gusta. Me parece que está bueno. Sobre todo porque la gente que va por ahí no conoce, en algunos casos. Nosotros tocamos ahí en la Metodista, en La Plata, y a veces va gente de la iglesia, viste, del barrio, y por ahí está bueno alguna explicación. Sino es todo muy acartonado. Tampoco hablar como un loro, pero dos boludeces. Hablamos, explicamos, los cellos, las cuerdas, de Casals, de cuando encontró las Suites... Está bueno.

I - Es como hablarles, mirarlos.

M - Claro.

I - Y mirás a la gente?

M - No, pero si miro... al infinito. Trato de mirar lo que pasa. No a los ojos a la gente, pero si mirar.

I - ¿Y algún ruido te cambia lo que estás tocando?

M - Depende. Y depende la concentración a la que llegues que nunca es la misma. Si hay como más concentración no pasa nada, pero si estás en cualquiera... eso es diferente, siempre. 


\section{Referencias}

Abbate, C. (1991). Unsung Voices: Opera and Musical Narrative in the Nineteenth Century. Prínceton: Princeton University Press.

Acero, J. J. y Villanueva, N. (2012). Wittgenstein y la intencionalidad de lo mental. Análisis filosófico, 32, 117-155

Adorno, T. W. (1971). Mahler: Eine musikalische Physiognomik. En G. Adorno y R. Tiedmann (Eds.) Gesammelte Schriften, xiii, ed. Frankfurt, pp. 149-319

Almén, B. (2008). A Theory of Musical Narrative. Bloomington: Indiana University Press.

Alonso, L. R. (1994). Sujeto y discurso: el lugar de la entrevista abierta en las prácticas de la sociología cualitativa. En J.M. Delgado y J. Gutierrez (Coords.) Métodos y técnicas cualitativas de investigación en ciencias sociales, pp. 225-240. Madrid: Síntesis.

Bal, M. (1997). Narratology: Introduction to the Theory of Narrative [Teoria de la Narrativa (Una introducción a la narratología) (J. Franco, trad.) Madrid: Cátedra, 1998]. Toronto: University of Toronto Press.

Bengtsson, I., y Gabrielsson, A. (1977). Rhythm research in Uppsala. En Music, Room, Acoustics. Stockholm: Royal Swedish Academy of Music, 17: 19-56.

Benson, B. E. (2003). The Improvisation of Musical Dialogue: A Phenomenology of Music. Cambridge: Cambridge University Press.

Bonds, M. E. (2014). Absolute Music. The History of an Idea. Oxford: Oxford University Press

Boorman, S. (1999). The musical text. En N. Cook y M. Everist (Eds) Rethinking Music, pp. 403-423. Oxford: Oxford University Press.

Bordoni, M., Español, S., De Grande, P. (2016). La incidencia del entonamiento afectivo y la imitación en el involucramiento visual-social temprano. Avances en Psicología Latinoamericana, 34(3), 487-503.

Broude, R. (2012). Musical Works, Musical Texts, and Musical Editions: A Brief Overview. Scholarly Editing: The Annual of the Association for Documentary Editing, 33, 1-29.

Bruner, J. (1986). Actual Minds, Possible Worlds [Realidad Mental y Mundos Posibles. Los Actos de la Imaginación que Dan Sentido a la Experiencia (B. López, trad.) Barcelona: Gedisa, 2004]. Cambridge, MA: Harvard University Press.

Bruner, J. (1990). Acts of Meaning [Actos de Significado. Más Allá de la Revolución Cognitiva (J. C. Gómez Crespo y J. L. Linaza (trads.) Madrid: Alianza, 1991]. Cambridge, MA: Harvard University Press.

Bruner, J. (2002). Making stories. Law, literature, life [La Fábrica de Historias. Derecho, Literatura, Vida (L. P. López, trad.) Buenos Aires: Fondo de Cultura Económica, 2003]. New York: Farrar, Strauss and Giroux.

Burrows, D. (1987). Instrumentalities. The Journal of Musicology, 5(1), 117-125. 
Butt, J. (2015). What is a 'Musical Work? Reflections on the origins of the 'work concept' in western art music'. En A. Rahmatian (Ed.) Concepts of Music and Copyright: How Music Perceives Itself and How Copyright Perceives Music, pp.1-22.Cheltenham: Edward Elgar Publishing.

Caplow, Th. (1956). The dynamics of information interviewing. The American Journal of Sociology, 62(2), 165-171.

Chatman, S. (1978). Story and Discourse: Narrative Structure in Fiction and Film. Ithaca, London: Cornell University Press.

Chatman, S. (1981). What novels can do that films can't (and vice versa). En W. Mitchell (Ed.) On narrative, pp. 117-136. Chicago: The University of Chicago Press.

Chua, D. K. L. (1999). Absolute Music and the Construction of Meaning. Cambridge: Cambridge University Press.

Clarke, E. (1999). Musical autonomy revisited. En N. Cook y M. Everist (Eds) Rethinking Music, pp. 172-183. Oxford: Oxford University Press.

Clarke, E. (2004). Empirical methods in the study of performance. En N. Cook y E. Clarke (Eds.) Empirical Musicology: Aims, Methods, Prospects, pp. 77-102. Oxford: Oxford University Press.

Clarke, E. (2005). Ways of Listening: An Ecological Approach to the Perception of Musical Meaning. Oxford: Oxford University Press.

Cobley, P. (2001). Narrative. New York: Routledge.

Cone, E. T. (1968). Musical Form and Musical Performance. New York: Norton.

Cone, E. T. (1974). The Composer's Voice. Berkeley: University of California Press.

Contursi, M. E. y Ferro, F. (2000). La Narración. Usos y Teorías. Buenos Aires: Norma.

Cook, N. (2001). Between process and product: Music and/as performance. Music Theory Online, 7(2).

Cook, N. (2003). Music as performance. En M. Clayton, T. Herbert y R. Middleton (Eds). The Cultural Study of Music. A Critical Introduction, pp. 204-214. New York y Londres: Routledge.

Cook. N (2013). Beyond the Score: Music as Performance. Oxford: Oxford University Press.

Cook, N. y Everist, M. (eds) (1999). Rethinking Music. Oxford: Oxford University Press.

Cross, I. (2010). La música en la cultura y la evolución. Epistemus, 1, 9-19.

Dahlhaus, C. (1978). Die Idee der Absoluten Musik. [La Idea de la Música Absoluta (R. Barce Benito, trad.) Barcelona: Idea Books, 1999]. Kassel: Bärenreiter.

Davidson, J. W. (1993). Visual perception of performance manner in the movements of solo musicians. Psychology of Music, 21, 103-113.

Davies, D. (2011). Philosophy of the Performing Arts, Malden, MA: Wiley-Blackwell.

Davies, S. (1988). Review del libro The Work of Music and the Problem of Its Identity, por Roman Ingarden. Journal of Music Theory, Vol. 32(1), 169-176.

Davies, S. (1994). Musical Meaning and Expression. Ithaca: Cornell University Press. 
Davies, S. (2011). Music and metaphor. En: S. Davies (Ed.) Musical Understandings and Other Essays on the Philosophy of Music, pp. 11-33. Oxford: Oxford University Press.

De Jaegher, H., y Di Paolo, E. A. (2007) Participatory sense-making: An enactive approach to social cognition. Phenomenology and the Cognitive Sciences, 6(4), 485-507.

Debus, D. (2007). Being emotional about the past: On the nature and role of pastdirected emotions. Noûs 41(4), 758-779.

DeNora, T. (2000). Music in Everyday Life. Cambridge: Cambridge University Press.

Denzin, N. K. (1970). The research act. Chicago: Aldine.

Dexter, L. (1970). Elite and specialized interviewing. Evanston: Northwestern University Press.

Español, S. (2010). Performances en la infancia: cuando el habla parece música, danza y poesía. Epistemus, 1, 57-95.

Español, S. (comp.) (2014). Psicología de la Música y del Desarrollo. Una exploración interdisciplinaria sobre la musicalidad humana. Buenos Aires: Paidós.

Etkin, M., Cancián, G., Mastropietro, C. y Villanueva, M. C. (2001). Cita y ornamentación en la música de Gerardo Gandini. Revista del Instituto de Investigación Musicológica "Carlos Vega", 9, 35-56.

Flick, U. (2006). An Introduction to Qualitative Research, 3th ed. [Introducción a la Investigación Cualitativa (T. del Amo, trad.) Madrid: Morata, 2012]. London: Sage.

Flick, U., von Kardoff, E. y Steinke, I. (2004). What is qualitative research? An introduction to the field. En U. Flick, E. von Kardorff ay I. Steinke (Eds) $A$ Companion to Qualitative Research, pp. 3-11. London: Sage.

Fludernik, M. (2003). Natural narratology and cognitive parameters. En D. Herman (Ed) Narrative Theory and the Cognitive Sciences. Stanford: CSLI Publications, pp. 243-267.

Fludernik, M. (2009). An Introduction to Narratology. New York: Routledge.

Frith, S. (1996). Performing Rites. On the Value of Popular Music. [Ritos de la Interpretación. Sobre el Valor de la Música Popular (F. A. Rodríguez, trad.) Buenos Aires: Paidós, 2014]. Cambridge, MA : Harvard University Press.

Gabrielsson A. (1987). Once again: the theme from Mozart's piano Sonata in A Major (k.331). En A. Gabrielsson (ed.) Action and perception in rhythm and music, pp. 81-103. Stockholm: Royal Swedish Academy of Music.

Gabrielsson, A. (1999). The performance of music. En D. Deutsch (Ed) The Psychology of Music, 2nd ed., pp. 501-602. San Diego, Calif.: Academic Press.

Genette, G. (1972). Figures III. [Narrative Discourse. An Essay in Method (J. E. Lewin., trad.) Ithaca: Cornell University Press, 1980]. Paris: Ed. du Seuil.

Genette, G. (1983). Nouveau Discours du Récit [Nuevo Discurso del Relato (M. Rodríguez Tapia, trad.) Madrid: Cátedra, 1998]. Paris: Ed. du Seuil.

Goehr, L. (1989). Being true to the work. The Journal of Aesthetics and Art Criticism, 47(1), 55-67. 
Goehr, L. (1992). The Imaginary Museum of Musical Works. Oxford: Clarendon Press.

Gomila, A. (2008). Música y Emoción: El problema de la expresión. En M. de la P. Jacquier y A. Pereira Ghiena (Eds.) Actas de la VII Reunión de SACCoM, pp. 1-8. Buenos Aires: SACCoM.

Gomila, A. (2013). San Lorenzo en la ESMA: sobre la ambigüedad moral de la música. En F. Shifres, M. de la P. Jaquier, D. Gonnet, M. I. Burcet y R. Herrera (eds.) Actas de ECCoM, 1(2), 403-416.

Goodman, N. (1976). Languages of Art. Indianapolis: Hackett Publishing Company.

Goodman, N. (1984). Of Mind and Other Matters. Cambridge, MA: Harvard University Press.

Gorden, R. (1975). Interviewing. Strategy, techniques and tactics, Homewood, Illinois: Dorsey Press.

Hatten, R. S. (1989). Semiotic perspectives on issues in music cognition. In Theory Only, 11(3), 1-11.

Hatten, R. S. (2004). Interpreting Musical Gestures, Topics, and Tropes: Mozart, Beethoven, Schubert. Indiana: Indiana University Press.

Hill, P. (2002). From score to sound. En J. Rink (ed.). Musical Performance: A Guide to Understanding, pp. 129-143. Cambridge: Cambridge University Press.

Hindemith, P. (1952). A Composer's World, Cambridge, MA: Harvard University Press.

Høffding, S. and Martiny, K. (2015). Framing a Phenomenological Interview: What, Why and How. Phenomenology and the Cognitive Sciences, 15(4), 539-564.

Imberty, M. (1997). Peut-on parler sérieusement de narrativité en musique? En A. Gabrielson (Ed.) Proceedings of the Third Triennal ESCOM Conference. University of Uppsala, pp. 23-32.

Ingarden, R. (1986). The work of music and the problem of its identity. (A. Czerniawski, trad.). London: Macmillan.

Iser, W. (1978). The Act of Reading: A Theory of Aesthetic Response. Baltimore: The John Hopkins University Press.

Juslin, P. y Sloboda, J. A. (2001). "Music and emotion: introduction.". En P. Juslin y J. A. Sloboda (Eds.) Music and Emotion. Theory and Research, pp. 3-20. New York: Oxford University Press.

Kivy, P. (2001). New Essays on Musical Understanding [Nuevos Ensayos sobre la Comprensión Musical (V. Canales, trad.) Barcelona: Paidós, 2005]. Oxford: Oxford University Press.

Klein, M. (2004). Chopin's fourth ballade as musical narrative. Music Theory Spectrum, 26(1), 23-56.

Klein, M. L. (2013). Musical story. En M. L. Klein, y N. Reyland (Eds) Music and Narrative since 1900, pp. 3-28. Bloomington: Indiana University Press.

Klein, M. L. y Reyland, N. (eds) (2013). Music and Narrative since 1900. Bloomington: Indiana University Press.

Kramer, L. (1990). Music as Cultural Practice, 1800-1900. Berkeley: University of California Press. 
Lakoff, G. y Johnson, M. (1980). Metaphors We Live By [Metáforas de la Vida Cotidiana (C. G. Marín, trad.) Madrid: Ediciones Cátedra, 1986] London: The University of Chicago Press.

Lawson, C. (2002). Performing through history. En J. Rink (ed.). Musical Performance: A Guide to Understanding, pp. 3-16. Cambridge: Cambridge University Press.

Leman, M. (2008). Embodied Music Cognition and mediation technology. Cambridge, MA: MIT Press.

López-Cano, R. y San Cristóbal, U. (2014). Investigación Artística en Música. Problemas, Métodos, Experiencias y Modelos. Barcelona: Fonca-Esmuc.

Malloch, S. (1999/2000). Mothers and infants and communicative musicality. Musicæ Scientiæ, Special Issue, 29-57.

Malloch, S. y Trevarthen, C. (eds.) (2009). Communicative musicality: exploring the basis of human companionship. Oxford \& New York: Oxford University Press.

Margolis, J. (1974). Works of Art as Physically Embodied and Culturally Emergent Entities. British Journal of Aesthetics, 14, 187-96.

Martin, P. (2006). Interpretación de música para laúd en guitarra, Parte 1. Clang, 1(1), 44-51.

Martínez, I. C. (2007). La composicionalidad de la performance adulta en la parentalidad intuitiva. En M. de la P. Jacquier y A. Pereira Ghiena (Eds.), Música y Bienestar Humano. Actas de la VI Reunión de SACCoM, pp. 25-34. Buenos Aires: SACCoM.

Martínez, I, C. (2008a). The cognitive reality of prolongational structures in tonal music (Tesis doctoral). University of Roehampton, Londres, Reino Unido. Recuperado de https://www.aacademica.org/martinez.isabel.cecilia/86.pdf

Martínez, I, C. (2008b). Cognición enactiva y mente corporeizada: el componente imaginativo y metafórico de la audición musical. Estudios de Psicología, 29(1), 31-48.

Martínez, I, C. (2014). La base corporeizada del significado musical. En S. Español (comp.), Psicología de la Música y del Desarrollo. Una exploración interdisciplinaria sobre la musicalidad humana, pp. 71-110. Buenos Aires: Paidós.

Martínez, I. C., Damesón, J., Pérez, J., Pereira Ghiena, A., Tanco, M. y Alimenti Bel, D. (2017). Participatory Sense Making in Jazz Performance: Agents' Expressive Alignment. En E. Van Dyck (Ed.) Proceedings of the 25th Anniversary Conference of the European Society for the Cognitive Sciences of Music. Ghent: IPEM.

Martínez, I. C., y Pereira Ghiena, A. (2015). Formas de vitalidad y ejecución expresiva. Un análisis del perfil sonoro-kinético de diferentes versiones del 'Preludio Op. 28, 7' de F. Chopin. En I. C. Martínez, A. Pereira Ghiena, M. Valles y M. Tanco (eds.) Actas de ECCoM, 2(2), 85-94.

Maus, F. E. (1988). Music as Drama. Music Theory Spectrum, 10, 56-73.

Maus, F. E. (1991). Music as narrative. Indiana Theory Review, 12, 1-34. 
Maus, F. E. (2005). Classical instrumental music and narrative. En J. Phelan y P. Rabinowitz (Eds.). A Companion to Narrative Theory, pp. 466-483. Oxford: Blackwell.

McClary, S. (2000). The Impromptu that trod on a Loaf or how music tells Stories. En M. McQuillan (Ed) The Narrative Reader, pp. 166-170. London: Routledge.

Meelberg, V. (2006). New Sounds, New Stories. Narrativity in contemporary Music. Leiden: Leiden University Press.

Merton, R. K. y Kendall, P. (1946). The focused interview. American Journal of Sociology, 51(6), 541-547.

Meuser, M. y Nagel, U. (1991). ExpertInneninterviews - vielfach erprobt, wenig bedacht: ein Beitrag zur qualitativen Methodendiskussion. En: D. Garz y K. Kraimer (Eds.) Qualitativ-empirische Sozialforschung : Konzepte, Methoden, Analysen, pp. 441-471. Opladen : Westdt. Verl.

Michotte, A. (1963). The perception of causality. London: Methuen.

Millar, R., Crute, V. y Hargie, O. (1992). Professional interviewing. London: Routledge.

Moran, D. (2000). Introduction to Phenomenology [Introducción a la Fenomenología (F. Castro Merrifield y P. Lazo Briones, trads.) Barcelona: Anthropos, 2011] London: Routledge.

Nattiez J-J. (1973) Y a-t-il une diégèse musicale? In: P. Faltin, H-P. Reinecke (Eds.) Musik und Verstehen: Aufsatze zur semiotischen Theorie, Asthetik und Soziologie der musikalischen Rezeption, pp 247-257. Cologne: Arno Volk Verlag/Hans Gerig KG.

Nattiez, J.-J. (1990). Can one Speak of Narrativity in Music?. Journal of the Royal Musical Association, 115, 240-257.

Nattiez, J.-J. (2013). The narrativization of music. Music: Narrative or Proto-Narrative?. Human and Social Studies, 2(2), 61-86.

Naveda, L., Martínez, I. C., Damesón, J., Pereira Ghiena, A., Herrera, R. y Ordás, A. (2016). Cross-Cultural Comparisons of Unconstrained Body Responses to Argentinian and Afro-Brazilian Music. En R. Kronland-Martinet, M. Aramaki y S. Ystad (Eds.) Music, Mind and Embodiment. 11th International Symposium, CMMR 2015, Plymouth, UK, June 16-19, 2015, Revised Selected Papers. Suiza: Springer International Publishing.

Newcomb, A. (1984). Once More "Between Absolute and Program Music": Schumann's Second Symphony. 19th-Century Music, 7(3), 233-250.

Newcomb, A. (1987). Schuman and late eighteenth-century narrative strategies. 19th Century Music, 11(2), 164-174.

Noë, A. (2004). Action in Perception. Cambridge, MA: MIT Press.

Noë, A. (2010). Out of Our Heads. New York, NY: Hill and Wang.

Palmer, C. (2013). Music performance: Movement and coordination. En D. Deutsch (Ed.) The Psychology of Music, Third ed., pp. 405-422. Amsterdam: Elsevier Press.

Patton, M. Q. (1990). Qualitative Evaluation and Research Methods. London: Sage. 
Pérez, J., Tanco, M., Martínez, I. C, Alimenti Bel, D., Damesón, J. y Pereira Ghiena, A. (2017). Corporeidad e intersubjetividad en la construcción del sentido musical: Análisis de la experiencia de interacción en la improvisación en jazz con dos saxofonistas. En V. Dillon (Comp.) Actas del $1^{\circ}$ Congreso Internacional de Enseñanza y Producción de las Artes en América Latina, CIEPAAL. La Plata: UNLP.

Popova, Y. B. (2014). Narrativity and Enaction: The Social Nature of Literary Narrative Understanding. Frontiers in Psychology 5, 895.

Popova, Y. B. (2015). Stories, Meaning, and Experience: Narrativity and Enaction. New York \& Abingdon: Routledge.

Povel, D-J. (1977). Temporal structure of performed music. Some preliminary observations. Acta Psychologica, 41, 309-320.

Repp, B. H. (1990). Patterns of expressive timing in performances of a Beethoven minuet by nineteen famous pianists. Journal of the Acoustical Society of America, 88, 622-641.

Ricoeur, P. (1984). Time and Narrative: Volume 1. Chicago and London: University of Chicago Press.

Ricoeur, P. (1985). Time and Narrative: Volume 2. Chicago: University of Chicago Press.

Ricoeur, P. (1988). Time and Narrative: Volume 3. Chicago: University of Chicago Press.

Rink, J. (1994). Chopin's Ballades and the Dialectic: Analysis in Historical Perspective. Music Analysis, 13(1), 99-115.

Rink, J. (ed) (1995). The Practice of Performance: Studies in Musical Interpretation. Cambridge: Cambridge University Press.

Rink, J. (1999). Translating musical meaning: The nineteenth-century performer as narrator. En N. Cook y M. Everist (Eds) Rethinking Music, pp. 217-238. Oxford: Oxford University Press.

Rink, J. (ed) (2002). Musical Performance: A Guide to Understanding. [La Interpretación Musical (B. Zitman, trad.) Madrid: Alianza Editorial, 2006] Cambridge: Cambridge University Press.

Roulston K. (2014) Analyzing interview data. En U. Flick (Ed) Handbook of qualitative data analysis, pp. 297-312. London: Sage.

Scheele, B. y Groeben, N. (1988). Diahg-Konsens-Methoden zur Rekonstniktion Subjektiver Theorien. Tubingen: Francke.

Schenker, H. ([1935] -1979). Der freie Satz [Free Composition (E. Oster, trad.)]. New York: Schirmer Books.

Schmidt, C. (2004). The analysis of semi-structured interviews. En U. Flick, E. von Kardorff ay I. Steinke (Eds) A Companion to Qualitative Research, pp. 253258. London: Sage.

Scruton, R. (1999). The Aesthetics of Music. Oxford: Oxford University Press.

Seashore, C. E. ([1938] 1967). Psychology of Music. New York: Dover. 
Shaffer, L. H. (1981). Performances of Chopin, Bach and Bartók: Studies in motor programming. Cognitive Psychology, 13, 326-376.

Shifres, F. (2007). Beyond Cognitivism. Alternative perspectives on the communication of musical structure through performance (Tesis doctoral). University of Roehampton, Londres, Reino Unido. Recuperado de https://www.aacademica.org/favio.shifres/160

Sloboda, J. A., y Howe, M. (1991). Biographical precursors of musical excellence: An interview study. Psychology of Music, 19, 3-21.

Sloboda, J. A., y Howe, M. (1992). Transitions in the early musical careers of able young musicians: Choosing instruments and teachers. Journal of Research in Music Education, 40, 283-294.

Small, C. (1998). Musicking: The Meanings of Performing and Listening. Hanover y Londres: Wesleyan University Press.

Sperber, D. y Wilson, D. (1977). Mutual knowledge and relevance in theories of comprehension. En N. V. Smith (Ed) Mutual Knowledge, pp. 61-85. London: Academic Press.

Spradley, J.P. (1980). Participant Observation. New York: Rinehart and Winston.

Stern, D. N. (1985). The Interpersonal World of the Infant : A View from. Psychoanalysis and Developmental Psychology [El Mundo Interpersonal del Infante (J. Piatigorsky, trad.) Buenos Aires: Paidós, 1991] New York: Basic Books.

Stern, D. N. (2010). Forms of Vitality: Exploring Dynamic Experience in Psychology and the Arts. New York: Oxford University Press.

Talbot, M. (2000). The Work-Concept and Composer-Centredness. En M. Talbot (Ed.), The Musical Work: Reality or Invention?, pp. 168-186. Liverpool: Liverpool University Press.

Tanco, M. (2013a). El concepto de color en la música. Experiencia corporeizada, analogía y pensamiento metafórico en la cognición musical. En F. Shifres, M. de la P. Jaquier, D. Gonnet, M. I. Burcet y R. Herrera (eds.) Actas de ECCoM, 1(1), 315-321.

Tanco, M. (2013b). El cuerpo como identidad del músico: Energía, movimiento y esquema corporal en la percepción multimodal de la performance. En F. Shifres, M. de la P. Jaquier, D. Gonnet, M. I. Burcet y R. Herrera (eds.) Actas de ECCOM, 1(1), 307-314.

Tanco, M. y Aún A. (2013). Audición armónica extendida. El rol del cuerpo y la experiencia en el uso del instrumento musical. Epistemus, 2, 123-177.

Tanco, M., Martínez, I. C., y Damesón, J. (2015). La idea de centro en la música tonal y su manifestación corporeizada en la performance instrumental. En I. C. Martínez, A. Pereira Ghiena, M. Valles y M. Tanco (eds.) Actas de ECCoM, 2(2), 105-115.

Tanco, M., Tobio, P. y Aún, A. (2012). Forma dinámica y transformación - el lenguaje metafórico en las descripciones de la experiencia corporeizada de la música. En Actas de las /l Jornadas de Música: Nuevos Paradigmas. Rosario: UNR. 
Tarasti, E. (1994). A Theory of Musical Semiotics. Bloominton and Indianapolis: Indiana University Press.

Taruskin, R. (1995). Text and Act. Oxford: Oxford University Press.

Taylor, S. J. y Bogdan, R. (1984). Introduction to Qualitative Research Methods. The Search for Meanings, 2nd ed. [Introducción a los Métodos Cualitativos de Investigación. La Búsqueda de Significados (J. Piatigorsky, trad.) Barcelona: Paidós, 1987] New York: John Wiley and Sons.

Thom, P. (2011). Authentic Performance Practice. En T. Grayck y A. Kania (Eds.) The Routledge Companion to Philosophy and Music, pp. 91-100. New York: Routledge.

Trevarthen, C. (1979). Instincts for human understanding and for cultural cooperation: Their development in infancy. En M. von Cranach, K. Foppa, W. Lepenies, and D. Ploog (Eds) Human Ethology: Claims and Limits of a New Discipline, pp. 530-571. Cambridge: Cambridge University Press.

Trevarthen, C. (1999/2000). Musicality and the Intrinsic Motive Pulse: evidence from human psychobiology and infant communication. Musica Scientie, Special Issue, 155-213.

Valles, M. S. (1997). Técnicas Cualitativas de Investigación Social: Reflexión Metodológica y Práctica Profesional. Madrid: Síntesis.

Varela, F. J., Thompson, E. y Rosch, E. (1991). The Embodied Mind: Cognitive Science and Human Experience [De Cuerpo Presente: las Ciencias Cognitivas y la Experiencia Humana (C. Gardini, trad.) Barcelona: Gedisa, 1992] Cambridge, MA: MIT Press.

Walls, P. (2002). Historical performance and the modern performer. En J. Rink (ed.). Musical Performance: A Guide to Understanding, pp. 17-34. Cambridge: Cambridge University Press.

Webster, J. (1991). Haydn's "Farewell" Symphony and the Idea of Classical Style. Cambridge: Cambridge University Press.

Weinrich, H. (1968). Estructura y Función de los Tiempos en el Lenguaje. Madrid: Gredos.

Witzel, A. (1985). Das problemmzentrierte interview. En G. Juttemann (Comp.) Qualitative Forschung in der Psychologie, pp. 227-255. Weiheim: Beltz. 